\title{
Imágenes Fotográficas sobre Pueblos Indígenas
}

Un enfoque antropológico

Tesis para optar por el grado de Doctor en Ciencias Naturales

Tesista: Lic. Alejandro Martínez

Directora: Dra. Liliana Tamagno

Codirectora: Dra. Irina Podgorny

Facultad de Ciencias Naturales y Museo

Universidad Nacional de La Plata

La Plata, 2010 
Martinez , Alejandro Raúl

Imágenes fotográficas sobre pueblos indígenas : un enfoque antropológico . - 1a ed. -

La Plata : Universidad Nacional de La Plata, 2012.

E-Book.

ISBN 978-950-34-0779-0

1. Tesis de Doctorado. 2. Fotografías. 3. Antropometría. I. Título CDD 573

Fecha de catalogación: 01/11/2011 
A Marita, y a Febe 


\section{INDICE}

Agradecimientos

INTRODUCCIÓN

CAPÍTULO I: Carlos Bruch fotógrafo-viajero del Museo de La Plata

Los Bruch en el Museo de La Plata

25

La fotografía entomológica

30

La "Colección Carlos Bruch"

33

Un "fotografista" en viaje por el Noroeste

37

Los viajes a la Patagonia, la Puna y Misiones

42

El viaje al Ingenio La Esperanza

54

CAPÍTULO II: La fotografía como evidencia científica

y como objeto de intercambio

63

Los difusos límites entre la fotografía "comercial" y la fotografía "científica"

63

El "redescubrimiento de los guayaquíes"

67

EI Museo de La Plata y la "cuestión guayaquí"

75

La serie fotográfica de 1894 y su trayectoria

83 
Guido Boggiani, el Museo de La Plata y

la colección de tipos indígenas de Sudamérica Central

La muerte de Boggiani y las disputas entre

sus albaceas

97

Fotografía, objeto de intercambio y evidencia científica

CAPITULO III: La fotografía y la visualización de tipos raciales en la obra de Robert Lehmann-Nitsche

Robert Lehmann-Nitsche, la antropología física y las definiciones de raza y tipo racial

Robert Lehamnn-Nitsche y la aplicación de la fotografía en los estudios antropológicos

"Un tráfico inmoral", los Takshik en Buenos Aires

La "Fotografía Antropológica" y las recomendaciones de la Escuela de Antropología de Paris

El "método" de Gustav Fritsch 
Los "obreros de la ciencia" y la divulgación

de sus investigaciones

160

De la fotografía "antropológica" a la fotografía "artística"

166

El fin de la serie de "estudios y relevamientos antropológicos"

176

CONSIDERACIONES FINALES

181

BIBLIOGRAFÍA

186 


\section{AGRADECIMIENTOS}

Debo agradecer en primer lugar a mis directoras por darme la oportunidad y el apoyo necesario para llevar adelante este proyecto. Liliana Tamagno me introdujo en la antropología y a ella debo especialmente mi interés por el conocimiento de la historia, la trayectoria, las presencias y las luchas de los pueblos indígenas. Irina Podgorny me mostró el camino de la investigación histórica, y sus francas críticas y valiosas enseñanzas abonaron buena parte de este trabajo.

En distintos momentos de esta investigación Clarice Ehlers Peixoto, Silvia Ametrano, Laura Miotti, Marta Maffia, Pablo Rodríguez, Gastón Gordillo, Paul Jenkins, Gregor Wolff, Peter Birle, Peter Mason, Sandra Carreras, Ramiro Segura, Kathrin Reinert, Adelina Pusineri, Axel Bachmann, Adolfo Ruig Alsina, Luis Compagnucci, Rodolfo Raffino, Diego Gobbo, Jorge Kreiderberg, Gabriel Alarcón, María Delia Arenas, Marta Garrido, Carlos Tremouillies, Roque Díaz, Susana Salceda, Horacio Calandra, Guillermo Lamenza, Jota Cascardi, Xavier Kriscautzky, Mónica López D’Urso, Miriam Hara, Carolina Soler, Bruno Pianzola, Facundo Escobar, Juan Manuel Di Socio, Gervasio Cieza y Leticia Recepter supieron apoyarme de distintas maneras, por medio de cartas de presentación a becas, apoyo institucional, sugerencias bibliográficas, discusión de ideas, aporte de datos relevantes, préstamo de libros, consulta de materiales y colecciones, entre otras.

Mis compañeros en el Laboratorio de Investigaciones en Antropología Social, especialmente Agustín Samprón, Mariel Cremonesi, Stella García, Leticia Katzer y Carolina Maidana, merecen mi agradecimiento por el apoyo brindado. $Y$ en ese sentido también deseo agradecer a Susana García, Tatiana Kelly, Máximo Farro y Diego Ballestero, con quienes he trabajado en el Archivo Histórico y Fotográfico del Museo. 
No puedo dejar de mencionar a todos mis compañeros del Posgrado; los que se fueron, los que siguen y los que vinieron. Analía Lanteri, Mirta García, Patricia Pereyra, Marcelo Barrera, Gabriela Morgante, Patricia Kavanagh, Verónica Ribelotta, Nano Maciá, Carolina Acosta Hospitaleche, y Fernanda Esnaola, en quienes siempre hallé sincero apoyo y constantes muestras de amistad.

Asimismo, debo agradecer especialmente a los empleados de la Biblioteca del Museo de La Plata, Biblioteca, Hemeroteca y Centro de Documentación de la Universidad Nacional de La Plata, Biblioteca de la Facultad de Humanidades y Ciencias de la Educación (UNLP), Hemeroteca de la Legislatura de la Provincia de Buenos Aires, Biblioteca Nacional, Biblioteca y Hemeroteca del Congreso de la Nación, Biblioteca del Instituto de Investigaciones en Geohistoria Regional (Resistencia, Chaco), Archivo Fotográfico del Museo Etnográfico Juan B. Ambrosetti, Archivo Histórico de la Provincia de Buenos Aires, Archivo General de la Nación, Archivo Histórico de la Cancillería Argentina, Museo Etnográfico Andrés Barbero (Asunción, Paraguay); en Berlin a la Biblioteca y Sección Legados del Instituto Iberoamericano, Biblioteca Estatal, Sociedad de Antropología, Etnología y Prehistoria, y Biblioteca de Arte, por su predisposición y paciencia para ayudarme a encontrar gran parte de la bibliografía y fuentes documentales que se utilizaron en esta tesis.

Esta investigación fue apoyada institucionalmente en sus primeros años por una beca para estudiantes de quinto año otorgada por la Fundación Museo de La Plata, y posteriormente por dos becas doctorales del CONICET y un subsidio para tesistas otorgado por la Facultad de Ciencias Naturales y Museo.

Finalmente quiero agradecer a toda mi familia y amigos, y especialmente a Marita y a Febe, a quienes debo la fuerza que necesité para llevar adelante este trabajo durante todo este tiempo. Por su paciencia, su amor y su alegría les voy a estar siempre agradecido. 


\section{RESUMEN}

En esta tesis se trabaja sobre la producción, uso y circulación de imágenes fotográficas sobre los pueblos indígenas del gran Chaco en relación al Museo de La Plata y entre finales del siglo XIX y principios del siglo XX. Se estudian por una parte los distintos contextos en que se produjeron las fotografías, los actores sociales e instituciones involucrados, las condiciones de posibilidad que permitieron la realización de esos trabajos y las relaciones establecidas entre fotógrafo y fotografiado. Se describe la actividad fotográfica de Carlos Bruch en los distintos viajes realizados por cuenta del museo y se señalan las principales características de su práctica fotográfica. Se describe y analiza, en el contexto del período en estudio, el uso otorgado a la fotografía en tanto objeto material, trazándose las trayectorias de la foto tanto a través de redes de comercialización como a través de redes de intercambio científico. En ese sentido se analizan los alcances de las distinciones entre lo "comercial" y lo "científico" y al mismo tiempo entre lo "amateur" y lo "profesional" en el campo de la antropología de fines del siglo XIX. Asimismo se describen y analizan algunas de las discusiones en torno al valor de la fotografía como evidencia científica y la relación entre fotografía y realidad. En referencia a la obra en materia de fotografía antropológica de Robert Lehmann-Nitsche se presentan y estudian distintos procedimientos, métodos e instrumentos diseñados con el fin de visualizar las "razas" y los "tipos raciales", su relación con la teoría antropológica del momento, y su carácter "científico". Se discuten las relaciones entre fotografía, poder y resistencias y en ese sentido se señalan los límites y alcances de la fotografía en tanto documento histórico en la formulación de hipótesis e interpretaciones. En referencia a las fotografías antropológicas se señalan las discusiones en torno a su definición, el quiebre de sus límites, y su acercamiento a la "fotografía artística" en el contexto de la búsqueda de nuevas miradas. Finalmente se ofrecen algunas explicaciones para comprender su abandono de la fotografía en tanto forma de conocimiento. 


\section{INTRODUCCIÓN}

El objetivo central de esa tesis doctoral es contribuir al conocimiento de la producción, uso y circulación de imágenes fotográficas sobre pueblos indígenas del gran Chaco a finales del siglo XIX y principios del siglo XX. Teniendo en cuenta que los primeros análisis de las fotografías consideradas "de interés antropológico" elaborados desde las ciencias sociales se encargaron de señalar el estrecho vínculo que existió durante el período considerado entre antropología y fotografía (Cfr. Edwards 1992, Pinney 1992), podemos afirmar que este objetivo tendrá, en este estudio, dos derivaciones. Por un lado se indagará en la aplicación de la fotografía a los estudios antropológicos especialmente aquellos de la antropología física- que se dieron en el marco del Museo de La Plata y su implicancia en la historia de la antropología argentina. Por otro lado también contribuirá a generar un mayor conocimiento sobre la historia y la trayectoria de los pueblos indígenas del gran Chaco.

Este trabajo describe y análiza las imágenes fotográficas de pueblos indígenas del gran Chaco existentes en el Archivo Histórico del Museo de La Plata, comparadas con los materiales fotográficos que se conservan en el Legado Robert Lehmann-Nitsche del Instituto Iberoamericano de Berlin ${ }^{1}$. Como señalaremos en forma más detallada al explicitar la metodología seguida durante esta investigación, se buscará entender a las fotografías en el marco del contexto histórico en el cual fueron producidas y "consumidas", para lo cual se plantea como necesario recurrir a otras fuentes de información; diarios y revistas, correspondencia personal y académica, y las consideraciones de los antropólogos y otros estudiosos de la época acerca de la aplicación de la fotografía en sus investigaciones. Este corpus documental, considerado en conjunto, aportará nuevos conocimientos acerca del uso y función de la fotografía en los distintos espacios de la práctica antropológica, y de las trayectorias de las fotografías tanto en los círculos académicos como en la actividad comercial. De

\footnotetext{
${ }^{1}$ A partir de una beca de investigación otorgada por esa institución, se pudieron consultar esos materiales durante el mes de octubre de 2009.
} 
este modo, brindando nueva información sobre los contextos de producción y circulación de las fotografías sobre pueblos indígenas del gran Chaco se contribuye al análisis antropológico de la cuestión indígena y en ese sentido abona la línea de investigación inaugurada por la antropóloga portuguesa Nélia Dias (1997), interesada en observar cómo se constituye la "mirada antropológica" a lo largo de la historia.

\section{Fotografía y antropología}

La bibliografía sobre fotografía histórica producida desde el campo de la antropología ha analizado, entre otros temas, la forma en que esta última disciplina estuvo vinculada a la producción y reproducción de los modos de ver y de comprender a los pueblos indígenas y de esa manera a la construcción de las identidades e imaginarios sobre esos pueblos. A nivel internacional, entre los innumerables ejemplos, tendremos especialmente en cuenta aquí los aportes de Elizabeth Edwards (1992, 2001), Edwards y Hart (2004), y Nelia Dias (1994a, 1994b y 1997). A nivel regional nos referiremos a las reflexiones y análisis sobre esta temática producidos desde a la Revista Chilena de Antropología Visual, órgano que difunde el trabajo de investigadores no solo de Chile sino de toda la región. En este marco cabe mencionar, entre los más significativos para nuestro análisis, los aportes de Margarita Alvarado sobre el papel de la fotografía y sus distintos mecanismos y dispositivos en la construcción de la alteridad (Alvarado 2000; 2001; Alvarado y Mason 2005; Alvarado y otros 2007, entre otros)². Por su parte Baéz se ha referido a los vínculos entre la fotografía y el texto escrito en relación a la construcción de la imagen del indígena fueguino (Báez 2001; 2005) y también, junto con Mason, a las fotografías de indígenas fueguinos que se hallaban en el contexto de la exhibiciones y ferias europeas de fines del siglo XIX (Báez 2004; Báez y Mason 2006).

\footnotetext{
${ }^{2}$ Es de destacar aquí que Alvarado y un grupo de investigadores de la fotografía en Chile y Argentina publicaron recientemente, en una excelente edición, una señera contribución al conocimiento acerca de las imágenes e imaginarios construidos sobre los indígenas fueguinos, analizando desde diferentes perspectiva un voluminosos corpus de fotografías de indígenas fueguinos tomadas entre 1880 y 1930 (Ver Alvarado y otros 2007)
} 
En nuestro país, a pesar de no contar con una publicación especializada en el tema, varios han sido los aportes que, especialmente desde los primeros años de la década de 1990 se vienen realizando sobre la fotografía de pueblos indígenas. Marta Penhos ha dedicado, desde ese entonces, numerosas páginas a tratar la relación entre la fotografía y la representación y la imagen pública de los pueblos indígenas (Penhos 1992, 1995) y más recientemente ha incursionado también en la "fotografía antropológica", planteando una relación entre ese género fotográfico y la "fotografía criminalística" (Penhos 2005). El trabajo de Mariana Giordano será tenido especialmente en cuenta aquí ya que representa a nuestro entender el antecedente más importante en estudios sobre las fotografías de indígenas del gran Chaco. Esta autora se concentra principalmente en el análisis de la construcción de la imagen y el imaginario del indígena chaqueño a través de fotografías históricas -y también textosproducidas en distintos contextos (Giordano 2003; 2004; 2005). Últimamente esta autora también ha avanzado sobre el análisis de la fotografía de indígenas y su relación con conceptos como identidad, ética, estética y memoria, enfatizando en los usos actuales de esa imágenes y su papel en la reproducción de imaginarios y estereotipos históricos (Giordano 2009, 2010). Uno de los aspectos de su trabajo que resulta significativo para las discusiones planteadas en esta tesis es el análisis del uso y significado de la fotografía en la antropología argentina (Giordano 2004, 2005), un terreno donde es pertinente mencionar además nuestras propias contribuciones (Martínez y Tamagno 2006; Martínez 2007, 2009).

Otro antecedente importante lo constituyen los trabajos de Carlos Masotta, quien desde hace una década estudia, entre otros temas, las tarjetas postales fotográficas de indígenas y su papel en lo que denomina una operación cultural, identitaria y tecnológica de creación de "indianidad", donde lo "indio" y lo "primitivo" quedaban igualados (Masotta 2005). Este autor también ha planteado la posibilidad de identificar en las imágenes, huellas e indicios de un encuentro desigual, rastros de docilidad, temor, rechazo o resistencia por parte de los fotografiados (Masotta 2003). En ese sentido también van los planteos de Fiore (2005) quien afirma que en las fotografías es 
posible visualizar un encuentro de subjetividades, ya que ellas han sido influidas tanto por la "agencia" del fotógrafo como del fotografiado.

Como anticipamos en el planteo de los objetivos aquí nos proponemos contribuir a la historia de la constitución de la "mirada antropológica". En ese sentido no será nuestro objetivo trabajar sobre la "representación" de los pueblos indígenas chaqueños por medio de la fotografía, aunque podamos hacer referencia a ello en algunos pasajes. Trabajaremos más bien en las cuestiones relacionadas a la producción, uso y circulación de la imagen fotográfica entendida como un objeto cultural cuyo significado e importancia son producto de relaciones sociales e históricas.

De ese modo las imágenes fotográficas aquí consideradas no solamente constituyen documentos que jalonan la historia de los archivos, de los repositorios documentales y de la antropología sino que son testimonio de la historia de la conformación de nuestra sociedad; una historia a partir de la cual hoy se hace y rehace la identidad de los pueblos indígenas que forman parte de ella. En este sentido autores como Barabas (2000); Barth (1976); Bartolomé (1997, 2000); Cardoso de Oliveira (1992); Cohen (1985); Pacheco de Oliveira (1999; 2006), Tamagno (2001, 2003, 2010) demuestran que los pueblos indígenas han formado parte de la gestación de la nación y forman parte activa de nuestra sociedad en tanto actores políticos y sujetos históricos. Durante el periodo que aquí consideramos los pueblos indígenas del gran Chaco comenzaron a sufrir una transformación crítica al verse alteradas sustancialmente sus condiciones de existencia frente al avance de la ocupación territorial por parte del blanco. En ese sentido es significativo señalar que, en 1884, cuando el General Victorica emprendía su campaña al Chaco con la intención de hacer efectivo el dominio del estado argentino sobre estos territorios, en un momento donde la cuestión indígena estuvo primariamente presente como asunto de estado íntimamente ligado a la conformación territorial (Lagos 2002), se realizaba la primera cosecha de caña de azúcar en el ingenio azucarero La Esperanza, San Pedro, Jujuy (Sierra e Iglesias 1998). Tal como señala Rutledge (1987), entre los años 1880 y 1930 los indígenas del Chaco fueron la 
principal mano de obra de los ingenios azucareros que se establecieron en la zona del Valle de San Francisco, Jujuy, concurriendo de a miles para trabajar en la zafra. Estos acontecimientos enmarcan un período que será crucial tanto para la historia de la antropología, como para la historia de los pueblos indígenas y para la historia de nuestro país en general y que ha sido tratado por los trabajos de Miller (1969), Cordeu y Siffredi (1971), Gordillo (1995, 2004,2006) Fuscaldo (1985), entre otros

\section{El Museo de La Plata}

Al mismo tiempo que las tropas del ejército penetraban en el Chaco y que se realizaba la primera zafra en el ingenio La Esperanza, se fundaba, por decreto el Poder Ejecutivo de la provincia de Buenos Aires, el Museo General de La Plata. Esta nueva institución, en su carácter de museo general para la provincia comprendía la producción artística e industrial del hombre así como todas las áreas del conocimiento relacionadas con la historia natural (Podgorny 1995, García 2010). Si bien la fecha de fundación del museo coincide con la campaña militar de "pacificación" del Chaco al mando de Victorica y los inicios de la industria azucarera, que tendría en la mano de obra de los indígenas chaqueños la base de su rentabilidad, el Museo de La Plata no incursionaría en esta región sino hasta dos décadas después, en agosto de 1906, cuando dos de sus investigadores concurrieron a ese ingenio $^{3}$ a fin de realizar un relevamiento antropológico. Para ese momento, Moreno había dejado su cargo de director, siendo reemplazado por el lingüista y arqueólogo Samuel Lafone Quevedo, y el museo había pasado a estar bajo la administración de la Universidad Nacional de La Plata.

Las iniciativas para el establecimiento de este tipo de instituciones como el Museo de La Plata, se fundamentaba en la necesidad de relevar, clasificar y cuantificar los recursos naturales y humanos del sur del continente, tarea que justificó la creación de varias instituciones que compitieron entre sí por el favor de los dineros públicos. Vinculado en la retórica de su promotor a la tarea de escribir la historia física y moral de

\footnotetext{
${ }^{3}$ Este ingenio se encuentra ubicado en el este de la provincia de Jujuy, en el valle de río San Francisco, una zona conocida como el Ramal y que incluye la región de Yungas y el Chao jujeño.
} 
la nación, el museo, al menos en sus documentos fundadores estuvo dedicado a exhibir los restos antropológicos y la cultura material indígena buscando mostrar las primeras etapas de la "evolución del suelo patrio". En ese sentido los indígenas sobrevivientes a las campañas militares de conquista fueron tratados como parte del territorio y se constituyeron en objeto de análisis y de observación; al mismo tiempo que su cultura material, sus cuerpos y sus restos óseos pasaron a formar parte de aquello sobre lo que, ahora, tenía soberanía la nación, tal como ha sido relatado, entre otros, por ten Kate (1904) y Lehmann-Nitsche (1908). De esta forma se buscaba albergar la historia del territorio, desde los más antiguos sedimentos hasta las manifestaciones del genio contemporáneo surgidas sobre este suelo (Podgorny 1999, 2008). Sin embargo, esa soberanía era más proclamada que real. Ni se llevaron adelante los planes originales, ni la provincia mantuvo el entusiasmo en hacerlo ni Moreno siguió tan entusiasmado por la antropología como en los inicios de la década de 1884. La competencia con un coleccionista privado de fósiles guiaría los pasos de la institución con tanta o más fuerza que la necesidad de reformular periódicamente los objetivos del Museo para lograr que se lo siguiera manteniendo desde el estado provincial o nacional (Podgorny y Lopes 2008, Podgorny 2000, Farro 2009, Podgorny 2009, García 2010).

Una parte del museo estuvo destinada a las colecciones de antropología física y cultural de los pueblos indígenas sudamericanos, jugando un importante papel en la conservación, exhibición, y estudio de objetos representativos de la historia de la naturaleza local y de los pueblos indígenas, así como también en el proceso de institucionalización de las prácticas de la historia natural y las ciencias antropológicas como una actividad profesional (Lopes y Podgorny 2000; Podgorny y Lopes 2008). El museo organizó diferentes estrategias para la recolección de objetos y datos, en función de los recursos humanos y financieros disponibles, donde el aprovechamiento de las oportunidades no previstas o las amistades y vínculos privados de empleados y directores jugaron un papel central. Lejos de un plan de estudio sistemático, la historia 
del Museo de La Plata exhibe improvisación, adaptación al medio institucional y político, y constantes cambios de rumbos.

En la tarea de registro el dispositivo fotográfico jugó un valioso papel; empleado como instrumento de registro en los viajes de campo, supuestamente permitiría crear un corpus de imágenes para la clasificación y el estudio de las "antiguas razas"; por su intermedio se podrían describir, comparar y analizar tanto los usos y costumbres como los caracteres físicos de estos pueblos. La fotografía por esos años no era considerada como un medio puramente ilustrativo sino que se pretendía utilizarla como prueba empírica, como dato científico que sirviera de apoyo a las teorías sobre el origen y la diversidad de las "razas humanas". De acuerdo con Spencer (1992), quien se refiere específicamente al uso de la fotografía entre los antropólogos anglosajones, había un movimiento definido a trascender los límites de la mera ilustración y antología, para emplear la imagen fotográfica como un dato científico "mensurable". Considerando que la ciencia moderna se fue constituyendo sobre la base de las tecnologías de replicación de la realidad, los medios ópticos y la evidencia construida de manera visual (Podgorny 2006), la fotografía le aportó a la ciencia del siglo XIX, un cambio en los modos de representación, la ilusión de haber conseguido un medio para llegar a la objetividad.

Por otra parte, en un contexto donde los pueblos indígenas se consideraban como "razas en extinción" se remarcaba que el registro visual y material de los esos pueblos debía efectuarse en forma urgente. Bajo este lema, que subsistió al menos hasta el último tercio del siglo $\mathrm{XX}$ y que consideraba al aislamiento geográfico y social como factores críticos en la conservación de la diversidad cultural, antropólogos, naturalistas viajeros, exploradores y fotógrafos comerciales, entre otros, produjeron una multitud de documentos visuales para el consumo del público burgués, de los que no se excluyen los especialistas y las instituciones científicas. Muchas y extensas colecciones fotográficas se fueron acumulando en museos, bibliotecas, universidades y otras asociaciones eruditas de todo el planeta. (Garrido, Kelly y Martínez 2007) 


\section{Fotografías antropológicas}

A lo largo de esta tesis, y en forma recurrente, se apelará al término "fotografía antropológica". En muchos casos, ese término al igual que varios otros como "fotografía métrica", "fotografía antropométrica", "relevamientos matemáticos", o "fotografía fisiognómica" era utilizado por los antropólogos e investigadores del período considerado y en ese sentido serán definidos. En otros casos, sin embargo, cuando el término fotografía antropológica sea utilizado desde el presente, tomará un sentido amplio, que abarcará las anteriores categorías, a fin de distinguir aquellas imágenes que buscaban dar cuenta fundamentalmente de la naturaleza de los cuerpos y de sus características físicas, y que pretendían construir un inventario de imágenes para acceder al conocimiento de la variabilidad humana, en el sentido de identificar y describir "razas" y "tipos raciales". Con ese propósito, estas fotografías fueron construidas en base a una serie de convenciones, buscando construir una suerte de procedimiento estandarizado que permitiera normalizar los resultados de los trabajos fotográficos, de forma que las imágenes obtenidas sean comparables, independientemente del fotógrafo que las tomara, del lugar donde se tomaran o de las circunstancias en que se produjeron. Sin embargo, como veremos en los capítulos siguientes, esas convenciones no eran compartidas por todos los que utilizaban la fotografía en sus investigaciones y en torno a esa cuestión se generaron ricos debates entre los investigadores interesados por utilizar la fotografía en sus estudios.

Según estas convenciones el fondo de la imagen debía ser "neutro" a fin de producir contraste con el cuerpo del retratado, aunque también podía ser un fondo "reticulado" que diera idea de sus dimensiones; en general se solicitaba a los modelos que conservaran una postura rígida con los brazos caídos a los costados del cuerpo, pero en muchas imágenes se observan pequeños desplazamientos y movimientos de las manos; en algunas fotos la persona retratada podía ir acompañada de una regla graduada, aunque a veces esto no sucedía; muchos sujetos aparecen vestidos aunque se aconsejaba tratar de conseguir retratos de desnudos; tal como podría imaginarse 
desde el presente, todos los sujetos fotografiados debían ser indígenas aunque también hallamos ejemplos de individuos europeos retratados de esa forma; para la toma de la fotografía se podía recurrir a un mobiliario diseñado especialmente a fin de lograr que el retratado conserve una postura rígida, aunque en otros casos esto no se consideraba necesario; en fin.

La observación detenida de las fotografías junto a lectura de los materiales de archivo donde se establecían y discutían distintos criterios para producir esta clase de imágenes no nos permitió caracterizar a la fotografía antropológica como un procedimiento claramente definido por una serie de reglas básicas compartidas, sino que más bien nos condujo a comprender que la variabilidad observada en esa clase de imágenes da la pauta tanto de las diversidad de concepciones acerca de lo que la fotografía permitía visualizar como de las numerosas discusiones en relación a la forma en que ello debía llevarse adelante.

Teniendo en cuenta estas consideraciones, nos quedó en claro que arriesgar una definición de la fotografía antropológica podía ser problemático y podía incluso llegar a opacar la complejidad del objeto investigado. A pesar de ello y al menos en lo que respecta a los materiales aquí revisados, se identificaron ciertas regularidades que pueden servir para esbozar una definición -en principio provisoria, discutible y enmarcada en los límites de esta tesis- no ya sobre "la" fotografía antropológica sino sobre las fotografías antropológicas, en plural, ya que no buscaremos definir los lineamientos teórico-metodológicos básicos de una determinada práctica sino identificar, en términos visuales, ciertas recurrencias y repeticiones presentes en determinadas imágenes fotográficas. De este modo, consideraremos como fotografías antropológicas todas aquellas imágenes fotográficas que, en primer lugar y teniendo como único tema de interés al cuerpo humano, en su conjunto o parcialmente, buscaban aislarlo de cualquier otro elemento considerado externo a él. Esto, que algunos autores denominan "descontextualización", es una de las características principales de esta clase de fotografías. La cámara debía construir un cuadro que 
circunscriba en la imagen todo el cuerpo -fotografías de "cuerpo entero"-, o podía capturarlo desde la cintura hacia arriba -fotografías de "torso" o de "busto"-. Por otro lado, ambos encuadres fijaban la imagen de las personas exactamente de frente y/o exactamente de perfil, agregándose, eventualmente y para las fotografías de cuerpo entero, la vista de espaldas. La búsqueda, por momentos obsesiva, de perfeccionar estos procedimientos, llevará a algunos antropólogos, entre los cuales incluimos a Robert Lehmann-Nitsche (de quien nos ocuparemos detenidamente en este trabajo), a forzar estos imprecisos límites de la fotografía antropológica recurriendo a las miradas que se venían desarrollando desde el campo del arte con respecto a los modos de capturar la apariencia del cuerpo humano por intermedio del aparato fotográfico ${ }^{4}$.

\section{La fotografía, interrogantes e interpretaciones.}

En su libro Visto y no visto. El uso de la imagen como documento histórico, Peter Burke (2001) se refiere al tratamiento dado a las imágenes en la investigación histórica señalando que frecuentemente los historiadores suelen tratarlas como simples ilustraciones, reproduciéndolas en sus libros sin el menor comentario, o, en los casos en los que las imágenes se analizan en el texto, su testimonio es utilizado para ilustrar las conclusiones a las que el autor ya ha llegado por otros medios, y no para dar nuevas respuestas o plantear nuevas cuestiones. Esto podría explicarse, de acuerdo con Peters y Mergens (1977), por la abundancia de fuentes escritas para muchos tópicos de interés de los historiadores sociales y culturales, junto con la clase de preguntas realizadas por los historiadores las cuales no están formuladas de modo que el dato fotográfico pueda responder directamente. En este sentido Burke hace notar que en los últimos tiempos los historiadores -sobre todo desde los años '80- ampliaron sus intereses y expectativas incluyendo, además de la historia de los acontecimientos políticos, la economía y la sociedad; la historia de las mentalidades, la historia de la

\footnotetext{
${ }^{4}$ En forma mucho menos frecuente se utilizará el término "fotografía etnográfica" para referirnos a las fotos que nos brinden información acerca de la cultura material, las costumbres o los modos de vida de los pueblos indígenas, y donde se incluirán todas aquellas imágenes producidas no sólo por antropólogos sino también por misioneros, naturalistas viajeros, militares, exploradores, fotógrafos profesionales u otros actores sociales, y que aporten datos sobre las sociedades y culturas fotografiadas (Cfr. Fiore 2007).
} 
vida cotidiana, la historia de la cultura material, la historia del cuerpo, etc., para las que es necesario contar con distintos tipos de documentación entre la cuales la imagen ocupa un lugar. Para el caso de la historia del cuerpo por ejemplo, las imágenes pueden ser una guía para el estudio de los cambios experimentados por la ideas de salud y enfermedad, y todavía son más importantes como testimonio del cambio experimentado por los criterios de belleza, o de la historia de la preocupación por la apariencia externa tanto por parte de los hombres como de las mujeres. (Burke 2001:11) Estas nuevas líneas de investigación que contemplan el uso de estos materiales que anteriormente no habían sido considerados en toda su potencialidad, permiten "... expandir la discusión interdisciplinaria sobre el rol de la visualidad en la vida social que se opone al difundido sesgo logocéntrico que ha aquejado el análisis social." (Coronil, 2004:1)

En este trabajo la fotografía será entendida como documento histórico y como tal interpretada, interrogada, cuestionada y puesta en comparación con otras fuentes y documentos. Teniendo en cuenta las consideraciones de Coronil (2004), Peters y Mergen (1977), Burke (2001), Kossoy (2001) y Poole (1999) sobre la necesidad de analizar los contextos de producción y circulación de las imágenes, y considerar a la fotografía como un artefacto social (Scherer 1992), y de acuerdo con John Tagg (1988), sostenemos que las imágenes fotográficas son objetos que fueron elaborados por un determinado modo de de producción, y que se distribuyen, circulan y consumen en el contexto de determinadas relaciones sociales que les otorgan un uso, un significado y un valor. Siguiendo los argumentos de este autor, quien subraya el aspecto instrumental del dispositivo fotográfico, podemos entender que las fotografías son y fueron producidas de acuerdo con objetivos e intereses determinados, esto es, con la intención de mostrar algo, de determinada forma y para cierta audiencia. De ese modo las fotografías, -al igual que otros objetos pertenecientes a la cultura material- no pueden ser entendidas íntegramente si nos concentramos solo en un momento específico de su existencia; deben ser pensadas como pertenecientes a un continuo proceso de producción, intercambio, uso y significado (Edwards y Hart 2004). 
En este sentido, entendemos que el carácter de documento histórico que no viene dado con las imágenes fotográficas sino que debe construirse a través de un trabajo crítico sobre ellas. Según argumenta Coronil, los estudios de esta clase deberán llevar adelante "... la "operación historiográfica", tan correctamente descripta por Michel de Certau, a través de la cual los historiadores producen documentos y textos al reservar, recolectar, e interpretar materiales que previamente no eran considerados como "fuentes históricas."' (Coronil 2004:3) De esa manera, las fotografías podrán ser consideradas como documentos válidos para la investigaciones sociales a través de "una lectura sofisticada de estos documentos al generar un balance productivo entre tratar a las imágenes como textos y analizar los contextos de su producción y circulación." (Coronil 2004:3)

A pesar del valor que Burke (2001) otorga a las imágenes como documento histórico no deja de señalar los problemas referentes a su utilización en un contexto de investigación. $Y$ estos problemas son importantes a la hora de iniciar cualquier análisis de la imagen fotográfica. En ese sentido señala que la crítica de los testimonios visuales se encuentra poco desarrollada y se plantean, al igual que con los textos, problemas de contexto, función, retórica, etc., por lo que algunas imágenes pueden ofrecer testimonios más fiables que otras. Además nos advierte que no debemos pasar por alto la diversidad de las imágenes, de su utilización, de los artistas, y de las actitudes frente a ella en los distintos períodos de la historia (Burke 2001:18-20). La propuesta de Burke marca un hito importante en la concepción del uso de la fotografía en el sentido de que tiene implicancias epistemológicas; se busca comprender qué lugar ocupaba esa práctica en la sociedad y no ya la representación de la sociedad en las imágenes fotográficas. En este sentido nuestro análisis estará orientado a comprender la fotografía en tanto práctica y no en tanto modo de representación.

Para comenzar a delinear las características que debería poseer una lectura de tal clase para el campo de la antropología no podemos dejar de señalar la pertinencia de los aportes realizados por Joanna Scherer en su conocido ensayo "The photographic 
document: photographs as primary data in anthropological enquiry" (Editado en Edwards 1992). Esta autora, al tiempo que ofrece un detallado recorrido a través de la bibliografía anglosajona referida a la utilización de las imágenes fotográficas como fuente de datos útiles disponibles para la investigación antropológica, marca una serie de limitaciones y alcances relativos a esa cuestión. Entre las posibilidades que ofrece el estudio de las imágenes fotográficas para los científicos sociales hace especial énfasis en que ellas constituyen "...evidencia confiable abierta al análisis e interpretación" y de las que se podría “... extraer significado sociocultural relevante..." (Scherer, 1992:32). Este tipo de análisis es incluido por dicha autora dentro del ámbito de lo que ella denomina la "antropología de la comunicación visual", que abarcaría “... el estudio de la visión que el fotógrafo tiene del Otro, así como la perspectiva académica sobre el fotógrafo; el estudio de la influencia del observador, así como el uso de la imagen dado por su audiencia." (Scherer 1992:32). En este sentido el investigador debería aproximarse a la fotografía "como un artefacto social" a fin de "entender el proceso de interacción entre el productor de la imagen, el tema de la imagen, y el observador." (Scherer 1992:32). De esta forma vemos que un estudio reflexivo y crítico de las fotografías como el propuesto por Scherer y que aquí intentamos llevar adelante, busca poner en contexto las imágenes a fin de ayudar a la reconstrucción de las culturas, entendiendo que un punto crucial para la creación de hipótesis y el análisis resulta la contextualización de la imagen, un estudio del ambiente histórico cultural en el cual se produjeron las fotografías, lo que requiere la comprensión tanto de la cultura del fotógrafo como de la del sujeto fotografiado.

Finalmente resultan pertinentes para nuestros objetivos los planteos metodológicos de Deborah Poole quien busca desarrollar un "método antropológico para el estudio de la fotografía histórica" sugiriendo que la antropología debería estudiar los contextos culturales en los cuales se producen las imágenes fotográficas como así también la manera en que las fotografías históricas han dado forma a nuestro conocimiento sobre las identidades étnicas y culturales. En ese sentido ofrece algunas ideas sobre cómo hacer una antropología de la fotografía, diciendo que esta disciplina debe tomar como 
punto de partida el archivo a fin de apreciar la compleja interacción de miradas, intereses, instituciones y formas de poder que constituyen una fotografía. Un punto este último del que nos ocuparemos en distintas ocasiones.

Por otra parte resultan muy pertinentes para este trabajo, el interrogante que se plantea esta autora sobre si la tarea del antropólogo ante el archivo fotográfico deberá ser investigar y explicar el significado y los contextos culturales de las imágenes históricas en el pasado o explicar la presencia de cierta clase de imágenes en la formación de la cultura visual actual, de los discursos y los conocimientos subyacentes a nuestras propias ideas de raza, identidad, etnicidad y género (Poole 1999: 229). Respondiendo afirmativamente en ambos casos plantea seguidamente tres desafíos para los antropólogos, acercarse a la fotografía como una tecnología de representación con sus propias características semióticas y materiales y no como una simple representación visual. Luego reconocer la diversidad de miradas que convergen en una imagen fotográfica, así como el complejo conjunto de factores institucionales, históricos y culturales que determinan la conformación de estas miradas. Y por último le interesa indagar en el complejo campo de las relaciones establecidas entre fotografía y poder preguntándose hasta qué punto el carácter polisémico de la imagen fotográfica permiten que pueda volverse independiente de los discursos hegemónicos.

A lo largo de este trabajo intentaremos llevar adelante lo que esta última autora denomina la "tarea etnográfica" de investigar las historias y los significados originales de las imágenes sin restringir la importancia de estas imágenes al momento histórico en que fueron tomadas, y considerando el archivo como unidad de investigación, con su historia, lógicas de organización y reglas de acceso.

\section{El Archivo Fotográfico del Museo de La Plata}

Desde las lecturas y las reflexiones expuestas comenzamos a trabajar con las numerosas fotografías sobre los pueblos indígenas de nuestro territorio (gran Chaco, 
Pampa y Patagonia) que se conservan en el Museo de La Plata muchas de las cuales, permanecían allí almacenadas sin orden alguno, mientras que otras habían sido catalogadas de acuerdo a criterios clasificatorios fragmentarios y heterogéneos, lo que frecuentemente dio como resultado la pérdida de los contextos específicos en los cuales habían sido originadas. Por ese motivo, y antes de avanzar sobre la identificación del corpus fotográfico a estudiar se impuso la tarea de trabajar sobre la conformación histórica de este archivo y de las fotografías que allí se conservan. El énfasis puesto por Moreno en las publicaciones editadas por el Museo y particularmente en la fotografía, hizo que ese establecimiento se transformara en un repositorio de documentos visuales resultantes de las distintas investigaciones que allí se llevaban adelante. La historia y trayectoria de esas colecciones, que permanecen sin clasificar y en algunos casos en peligro debido a su propio formato físico y condiciones de almacenamiento inadecuadas, aún no fue analizada en profundidad. Las imágenes fotográficas que se conservan en el archivo y otras dependencias, pertenecen a los primeros 50 años de actividad del museo, (testimonios de las primeras expediciones, sus antiguas salas, los eventos científicos que allí tuvieron lugar, el material producido para apoyo de las diversas investigaciones realizadas, etc.) todo lo que las convierte en documentos imprescindibles a la hora de intentar reconstruir la historia de las disciplinas científicas desarrolladas en esa institución. Cabe agregar que en el ámbito del museo, el viaje de campo fue uno de los espacios fundamentales relacionados con la producción de imágenes fotográficas, pero no fue el único, ya que ellas se complementaban a su vez con fotografías obtenidas en otros contextos. Sin embargo hay que destacar que los viajes de campo se tratan de expediciones plurifuncionales, no expediciones antropológicas. En parte conectado a la falta de recursos, en parte por el desinterés que Moreno exhibió hacia la antropología a partir de 1890, cada viaje se dedicaba a la recolección de varias cosas. La serie de imágenes fotográficas más antiguas e identificadas fehacientemente, estuvo a cargo de fotógrafos profesionales de la casa de Samuel Boote ${ }^{5}$, quienes tomaron las fotografías del grupo de indígenas de

\footnotetext{
${ }^{5}$ Para ese año Samuel Boote manejaba dos locales comerciales de fotografía, ambos en Buenos Aires, uno de ellos ubicado en calle Cuyo 645 ofrecía el envío de un fotógrafo "a cualquier parte". Según Epifanio este fotógrafo podría haber sido su hermano, Arthur Wood Boote. El otro local se encontraba en Florida 179 (Epifanio 1994).
} 
Inacayal y Foyel, cuando se hallaban prisioneros en los cuarteles del regimiento 8 de línea ${ }^{6}$ en julio de 1885. Por otra parte, en este grupo también podemos incluir las fotos de objetos arqueológicos, hechos en piedra y cerámica, y montadas sobre cartulina con la marca de agua de la casa del por entonces renombrado fotógrafo portugués Christiano Junior ${ }^{7}$. En el contexto de nuestra tarea el análisis de los materiales de archivo nos permitió además conocer sobre ese trabajo campo y sobre los posteriores trabajo de gabinete.

El trabajo de los fotógrafos profesionales contratados por el museo, parece corresponder sin embargo a un período relativamente corto, y que comprende los primeros años de funcionamiento de esa institución. Posteriormente, desde la década de 1890 hasta los primeros años del siglo XX espacio de producción de fotografías relacionadas con la antropología fue el mismo museo, en cuyo patio o en alguno de sus gabinetes de investigación, se tomaron fotografías antropológicas. Muchas de estas fotos fueron tomadas por el personal del museo, como Hermann ten Kate, Charles de La Hitte, Robert Lehmann-Nitsche. Además, para 1889 ya habían comenzado a funcionar los talleres de publicaciones contiguos al museo (Farro 2009) donde se encontraba funcionando un laboratorio de fotografía que llevaba a cabo trabajos de obtención, revelado, copia e impresión de imágenes fotográficas para las publicaciones científicas editadas por el museo ${ }^{8}$, que se encontraba a cargo de Carlos Bruch, quien se desempeñaría allí como fotógrafo y fototipista, entre 1887 y $1900^{9}$. Por intermedio de estas publicaciones, Moreno buscaba que el Museo de La Plata “... sea apreciado en los altos medios científicos del mundo..." (Moreno 1896). Por ese motivo la organización definitiva de los talleres de publicaciones fue costeada por él mismo, ya que, según decía, “... no es posible confiar las publicaciones del Museo a

\footnotetext{
${ }^{6}$ El 30 de julio de 1885 una factura por el monto de \$188 moneda nacional de la casa de Samuel Boote emitida a nombre del "Museo y Biblioteca "La Plata"' decía: "Por sacar 47 retratos de indios con sus correspondientes negativos a \$4 c/uno" (AHPBA, Tribunal de cuentas).

${ }^{7}$ José Christiano de Freitas Enriques Junior, procedente de Brasil estableció un comercio fotográfico en Buenos Aires en 1868 en la calle Florida 160/64 (luego 208), pasando luego por distintas ubicaciones y permaneciendo activo hasta 1896 cuando anuncio su retiro aunque continuó ligado al comercio de fotografía de su hijo. Fue uno de los más destacados profesionales del medio en esa época (Gómez 1986: 155).

${ }^{8}$ Según Moreno (1890) se trataba de uno de los laboratorios de fotografía más completos del país.

9 Carlos Bruch (Munich 1869- Vicente López 1943) también tomó fotografías en las expediciones realizadas por cuenta del museo desde 1896, nos referiremos extensamente a estas actividades en el capítulo II.
} 
establecimientos que no cuentan con artistas especiales, dedicados a esta clase de impresiones". (Moreno 1890)

Las imágenes provenientes de las expediciones, las encargadas a fotógrafos profesionales y aquellas producidas en el gabinete fotográfico, habían sido obtenidas, como muchas otras colecciones del museo, para que "... cerebros expertos estudiaran más adelante todos estos materiales, en bien de la ciencia." (Moreno 1890). A raíz de la nacionalización del museo en 1906, y su consiguiente incorporación a la Universidad Nacional de La Plata la enseñanza superior de las ciencias naturales se incorporó como una nueva actividad, por lo que el uso de las imágenes fotográficas se extendió a ese ámbito, y bajo la forma de "proyecciones luminosas" fueron empleadas para ilustrar clases y conferencias, donde el aspecto educativo de la demostración se combinaba con el potencial del entretenimiento (García 2005:38)

El 22 de septiembre de 1937, tres décadas después del pase a la órbita nacional, se creaba el Archivo Fotográfico General del Instituto del Museo, mediante una resolución firmada por Joaquín Frenguelli, por entonces director de ese establecimiento. De acuerdo con esa disposición, el hecho de que una institución como el museo careciera de un archivo fotográfico organizado como tal, hacía que la tarea de constituirlo resultara imprescindible. Ese acervo, que iría a centralizar la mayor cantidad posible de documentos fotográficos (los disponibles a ese momento y los que habrían de obtenerse), serviría además para resguardarlos “...en un mueble de características especiales, que por distribución adecuada de aquellos permita su rápida y fácil consulta..."10. Se planteaba entonces la necesidad de contar con un corpus de imágenes debidamente catalogado y donde pudieran encontrarse reunidas las fotografías pertenecientes a la institución.

${ }^{10}$ Revista Museo de La Plata, Sección Oficial, 1937, pp. 146. 
Este énfasis puesto sobre la centralización ${ }^{11}$ y organización de los materiales fotográficos se correspondía con la intención de crear un archivo que funcionara como una fuente útil de consulta para docentes e investigadores. En este sentido, si advertimos que esos materiales quedarían “...a disposición de los interesados en la Biblioteca del Instituto."12, comprenderemos que ese propósito era una de las razones fundamentales para la creación del archivo. Es que el museo, especialmente luego de su traspaso a la órbita nacional en 1906, había adquirido la función de creador y difusor de imágenes e iconografías. De acuerdo con Podgorny (1992), dentro de las múltiples demandas que se planteaban a ese organismo desde otras instituciones públicas y privadas, se hallaba el pedido de ilustraciones, tanto para la industria de los manuales educativos como para la formación de museos escolares.

Para la fecha en que se redactó esta resolución, medio siglo después de la fundación del museo, se habían acumulado una gran cantidad de imágenes fotográficas, principalmente negativos de vidrio ${ }^{13}$, tanto en el laboratorio de fotografía como en otros departamentos del museo. Tal acumulación de imágenes; su dispersión por los diferentes departamentos del museo; y la ausencia, en muchos casos, de alguna referencia sobre su procedencia, autoría, contexto de producción o trayectoria; habían transformado cualquier intento de consulta de ese material en una aventura con resultados inciertos. Con el propósito de suplir esta falta de información se solicitaba a los investigadores que, en adelante, las fotografías que entregadas al archivo fueran acompañadas de todos los datos necesarios para su identificación precisa, los cuales serían volcados en una ficha elaborada a tal fin. Además, y para el caso de las fotografías de las que ya disponía el Museo al momento de la creación del archivo, se solicitaría a su personal la colaboración para completar la información sobre esas imágenes.

\footnotetext{
${ }^{11}$ Se pedía a los colaboradores de las publicaciones del museo que entregaran el negativo y una copia de las imágenes que utilizarían en sus artículos así como también se solicitaba a los jefes de cátedras y departamentos que entregaran las fotografías que conservaban en sus laboratorios. (Revista Museo de La Plata 1946, Resolución creando el Archivo Fotográfico General Art. 3 y 4 )

12 Revista Museo de La Plata, Sección Oficial, 1937, pp. 146.

13 En efecto, la gran mayoría de las fotografías antropológicas archivadas en el museo son negativos de vidrio, y aunque muchos de ellos hayan sido utilizados para ilustrar distintas publicaciones es notoria la ausencia de copias en papel fotográfico.
} 
Sin embargo y no obstante las precisas instrucciones ${ }^{14}$ y los recaudos que se tomaron para llevar adelante la administración y conservación de las colecciones fotográficas, no podemos afirmar que los objetivos propuestos se hayan cumplido en algún momento ya que a) muchas imágenes continúan dispersas por distintas dependencias del museo; b) no tenemos registro de que se haya conseguido realizar un fichaje completo y con un criterio unificado de los materiales fotográficos, y c) además, algunos de los intentos por referenciar las imágenes, presentan tanto vacíos de información como errores en los datos que las acompañan. Esta situación, con la que nos encontramos al momento de iniciar este trabajo de tesis en los primeros meses de 2006, nos a llevó a pensar que un archivo de tales características podía resultar semejante a un sitio arqueológico, en tanto que sometido a procesos físicos e históricos de los que habría que dar cuenta (Podgorny 1992); y que seguramente nos vendrían a ilustrar acerca de la política implementada desde el museo para la gestión de su propio pasado.

En efecto, a principios de 2006, pudimos identificar dos grandes colecciones fotográficas que tenían como tema a los pueblos indígenas del gran $\mathrm{Chaco}^{15}$, las cuales se hallaban almacenadas en tres diferentes dependencias del museo. La primera de estas colecciones, conformada por las imágenes tomadas en 1899 por Bruch y Lehmann-Nitsche a un grupo de indígenas takshik ${ }^{16}$ que se hallaba en Buenos Aires, estaba, y continúa estando, en el Departamento de Arqueología. La segunda de estas colecciones corresponde a las fotografías tomadas en el ingenio La Esperanza ${ }^{17}$ que

\footnotetext{
${ }^{14}$ A los fines de una mejor consulta de las imágenes archivadas la resolución de 1937 proponía un ordenamiento de los materiales en las siguientes secciones: Primera Sección: De interés general (edificio y sus dependencias, conferencias, actos públicos, instalaciones, etc.).Segunda Sección: Antropología. Tercera Sección: Arqueología y etnografía. Cuarta Sección: Botánica. Quinta Sección: Geología y Geografía física. Sexta Sección: Mineralogía y Petrografía. Séptima Sección: Paleozoología (Invertebrados) y Paleobotánica. Octava Sección: Paleozoología (Vertebrados).Novena Sección: Zoología (Invertebrados).Décima Sección: Zoología (Vertebrados).

15 Estas dos colecciones suman 226 fotografías, la mayoría de ellas son negativos de vidrio. Y constituyen el principal corpus de análisis de esta tesis.

${ }^{16}$ Se trata de un total de 46 negativos de vidrio en formato $13 \times 18 \mathrm{~cm}$. de cuyo análisis nos ocuparemos en el capítulo IV.

${ }^{17}$ Esta colección está conformada por 163 negativos de vidrio en formato $18 \times 24 \mathrm{cms}$., 1 diapositiva de vidrio de 8,5 X9,5 cm. que se conservan en el Archivo Histórico y Fotográfico, mientras que en el Departamento de Arqueología se hallan 6 diapositivas de $8 \times 8 \mathrm{~cm}$., 8 negativos de vidrio 9X12cm., y 2 copias en papel fotográfico de 9X12cm.
} 
componen la colección de imágenes más extensa sobre los indígenas del gran Chaco que se conservan en el Museo y que se hallaba dispersa para 2006, entre tres dependencias: el Laboratorio de Fotografía y el Departamento de Antropología, ubicados ambos en el subsuelo del museo ${ }^{18}$, y también en el Departamento de Arqueología que se encuentra en el primer piso del museo ${ }^{19}$. El trabajo de análisis de las fotografías junto al trabajo de archivo realizado abrió un panorama que por momentos se nos apareció como difícil de sistematizar. Los capítulos que a continuación se presentan surgen de una elección que podría no ser la única pero que esperamos que al menos de cuenta de la riqueza del material encontrado y de las posibilidades interpretativas que los mismos pueden ser capaces de generar.

En el Capítulo I nos concentramos en el desempeño fotográfico de Carlos Bruch en el Museo de La Plata. Comenzamos haciendo una breve reseña de su juventud, su llegada a la Argentina y al Museo de La Plata. Luego damos un panorama general de las actividades desarrolladas como empleado de los Talleres de Publicaciones del museo y su participación en diferentes viajes dentro de esa institución sobre todo como fotógrafo-viajero, haciendo además una breve referencia a su actividad dentro la fotografía entomológica. Posteriormente nos detenemos especialmente en el carácter documental que puede atribuirse a muchas de sus fotografías, presentando y analizando algunas de las vistas de paisajes, gentes y costumbres del país obtenidas durante sus viajes de campaña, un aspecto completamente desconocido de su desempeño como fotógrafo.

En el Capítulo Il se analiza el lugar de la fotografía en las discusiones antropológicas de fines del siglo XIX a partir de dos casos la "cuestión guayaquí", y los conflictos de

\footnotetext{
18 Las fotografías que se encontraban en estas dos dependencias fueron trasladadas el Archivo Histórico y Fotográfico, mientras que las que estaban en el Departamento de Arqueología continúan. A pesar este último grupo de imágenes y las tomadas en 1899 fueron microfilmadas y escaneadas recientemente por lo que se encuentran disponibles a la consulta en esos formatos.

19 Actualmente, aunque mucho del material fotográfico producido por esa institución sigue a la espera de un ordenamiento, las colecciones de fotografía antropológica, por medio de un proyecto integral que comenzó a mediados de 2006 y finalizó a mediados de este año, fueron objeto de tareas de limpieza, conservación, almacenamiento, inventario, descripción, microfilmación y escaneo, y ya se encuentran accesibles a la consulta pública (Garrido y otros 2007; Podgorny y Kelly 2010). Por ello es de esperar que en un futuro no muy lejano suceda algo similar con las fotografías producidas en el contexto de las demás disciplinas desarrolladas en esa institución.
} 
intereses que se desataron en torno a la colección fotográfica de tipos indígenas de Guido Boggiani. El primer caso nos ofrece la oportunidad poco frecuente de rastrear la producción, circulación y recepción de una serie acotada de imágenes fotográficas utilizadas como evidencia científica. Se resumen las primeras crónicas sobre este grupo. Se describen las circunstancias en las cuales Charles de La Hitte, quien fue empleado de la Sección Antropológica del museo, obtuvo en 1894 una serie de imágenes de un indígena guayaquí. Se destaca que el conjunto de imágenes obtenidas circularon a nivel internacional durante cerca de una década ilustrando las discusiones que sobre esta cuestión se abrieron en el campo de antropología decimonónica. Se realiza una descripción pormenorizada de la imagen más difundida de la serie tomada por La Hitte. En tanto el segundo caso nos permite visualizar el papel desempeñado por las fotografías en tanto objetos materiales en el contexto de las redes de intercambio científico establecidas a fines del siglo XIX y principios del siglo XX. Finalmente, enfatizando en el papel de la fotografía en la construcción de los objetos científicos, se discuten las posturas de los antropólogos de la época acerca de la relación entre fotografía y realidad.

Los Capítulos III y IV se encuentra estrechamente vinculados ya que en ellos nos introducimos en la descripción y análisis de la aplicación de la fotografía a los estudios antropológicos realizada por Roberto Lehmann-Nitsche quien fue, cómo mostraremos allí, una figura clave en la historia de la fotografía antropológica en el contexto del Museo de La Plata durante el período considerado. En el Capítulo III analizamos el papel que Lehmann-Nitsche otorgó a la fotografía en la visualización de los tipos raciales. Se hace una breve referencia a la formación de Lehmann-Nitsche, su llegada y actividades en el Museo de La Plata. Se inicia luego el análisis del trabajo fotográficoantropométrico realizado en 1899 por sobre un grupo de indígenas takshik del Chaco argentino. Se describen y analizan las circunstancias a través de las cuales fue posible para Lehmann-Nitsche acceder al estudio del grupo en cuestión. Se hace especial énfasis en la construcción del atlas fotográfico que fue publicado en 1904 en la revista del Museo de La Plata. Se tratan específicamente los criterios metodológicos puestos 
en práctica por el autor con el fin de acceder a la visualización de los tipos raciales. En el Capítulo IV se presentan y analizan las condiciones de posibilidad y circunstancias a través de las cuales Lehamnn-Nitsche pudo construir un "atlas antropológico" publicado en 1907 en los Anales del Museo de La Plata, con el título Estudios antropológicos sobre los Chiriguanos, Chorotes, Matacos y Tobas (Chaco Occidental). Ese trabajo de antropología física, donde la fotografía ocupaba un papel central fue realizado en 1906, en el ingenio azucarero La Esperanza (Jujuy) y allí se adjuntan una serie de aproximadamente 50 láminas con fotografías de trabajadores indígenas, obtenidas en el Ingenio azucarero La Esperanza, Jujuy, Argentina. Se describe el contexto en que se tomaron las mediciones antropométricas y las fotografías, haciendo énfasis en la relación de poder establecida entre los investigadores y los indígenas estudiados. Finalmente se hace referencia a los cambios producidos en la concepción de la fotografía antropológica por parte de Lehmann-Nitsche y su abandono de las investigaciones en antropología física. 


\section{CAPÍTULO I}

\section{Carlos Bruch fotógrafo-viajero del Museo de La Plata}

En este capítulo nos concentraremos en el desempeño fotográfico de Carlos Bruch en el Museo de La Plata, especialmente en su actividad como fotógrafo en los distintos viajes que emprendió en nombre de esa institución entre 1896 y 1908. Comenzamos haciendo una reseña biográfica refiriéndonos brevemente a su juventud y su llegada a la Argentina y al Museo de La Plata. Luego brindamos algunos detalles generales de las actividades que desarrollara como empleado de los talleres de publicaciones del museo. Seguidamente nos referimos a las técnicas y tecnología empleadas para la toma de fotografías de insectos. A partir de allí se presentan los distintos viajes que Bruch realizó por Argentina en el período considerado recorriendo la cordillera patagónica, la región del noroeste, el Chaco y Misiones. En algunos de estos viajes actuó como naturalista-viajero recolectando material arqueológico, zoológico, botánico, armando y adquiriendo colecciones para el museo. En otros actuó como acompañante y asistente de otros investigadores y científicos. En todos estos viajes, sin embargo, estuvo acompañado por su cámara de mano en formato $9 \times 12 \mathrm{~cm}$., con la que obtuvo, como veremos, centenares de imágenes, muchas de las cuales conformarían una colección de "positivos" que ofrecería en venta al museo a fines de 1910. Lo que actualmente se conserva de esa colección fotográfica nos muestra que esa imágenes no pertenecían a lo que podría denominarse "fotografía científica" en el sentido de que no estaban destinadas a ilustrar fenómenos de interés para las disciplinas científicas de ese momento ni tampoco habían sido construidas en arreglo a pautas predeterminadas. $Y$ aunque algunas de estas fotos fueron incluidas por Bruch en sus publicaciones ellas tomaron un carácter meramente ilustrativo. Por ello aquí entenderemos que las "vistas de paisajes, gentes y costumbres del país" obtenidas por Bruch durante sus viajes por el territorio argentino poseen un carácter documental en el sentido en el que lo plantea Newhall (1938), mostrándonos a su vez una faceta poco conocida de su actividad como empleado del Museo de La Plata e incluso de los usos 
dados a la cámara fotográfica en el contexto de las expediciones científicas, aportando nuevos datos para comprender la concepción del fenómeno fotográfico hacia fines del siglo IX y principios del siglo XX.

Los aportes que Carlos Bruch realizó en el campo de la entomología han sido analizados en las distintas publicaciones que se ocuparon de ello durante los últimos años de su vida (Lizer y Trelles 1937) y especialmente luego de su muerte (Birabén 1943a, 1943 b; Jörg 1943; Lizer y Trelles 1943a, 1943b, 1947; Mello Leitao 1943; Schedl 1946). Su desempeño en el campo de la entomología también aparece reseñado en publicaciones más recientes, destinadas a dar cuenta de la historia del campo de esa disciplina (Capinera 2008), o de los estudios de algún género de insectos a cuyo conocimiento Bruch contribuyera en forma significativa (Herman y Smetana 2001). Si bien en estas biografías se destaca y elogia la experticia y competencia de Bruch como fotógrafo -especialmente en Jörg (1943)-, su énfasis está puesto en lo referente a la aplicación de ese procedimiento a los estudios entomológicos, a los que comenzó a dedicarse exclusivamente recién a inicios de la década de 1910 (Cfr. Lizer y Trelles 1937). No se brindan mayores datos que den cuenta de los primeros años de actividad de Bruch en el Museo de la Plata, en particular en el período que va desde su llegada, hacia fines de 1887, hasta la década de 1910.

En ese sentido este capítulo no intenta brindar una biografía completa de la trayectoria científica de Carlos Bruch, sino que se concentrará en sus dos primeras décadas de actividad en el Museo de La Plata haciendo especial énfasis en su desempeñó como fotógrafo en los distintos viajes que emprendió en nombre de esa institución. La colección de fotografías que Bruch ofreció en venta al museo en diciembre de 1910 estaba conformada en su mayor parte por fotografías que él mismo tomó durante esos viajes. Particularmente las fotografías que tomó junto a Robert Lehmann-Nitsche en el marco de los estudios antropológicos realizados en Buenos Aires en 1899 y en Jujuy en 1906, conforman la casi totalidad de las imágenes fotográficas sobre pueblos indígenas del Gran Chaco que se conservan en el Archivo Histórico y Fotográfico del 
Museo de La Plata y que conforman la parte principal de nuestro corpus de estudio. En este sentido se comprende la importancia, para los objetivos de nuestra tesis, de detenernos en el estudio de este aspecto de la obra fotográfica de Carlos Bruch, que es prácticamente desconocido al día de hoy. A través de la descripción y análisis de estas imágenes y su contexto de producción buscaremos profundizar nuestro conocimiento sobre la relación establecida entre antropología y fotografía en el Museo de La Plata para el período considerado.

\section{Los Bruch en el Museo de Plata}

Como puede leerse en su legajo personal, que él mismo redactara, Carlos Bruch había nacido en Munich, Reino de Baviera el $1^{\circ}$ de Abril de 1869. Allí realizó sus estudios primarios, mientras que cursó estudios secundarios en el Colegio Real de esa misma ciudad y de Nuremberg. Según declara el propio Bruch desde muy joven sintió inclinación hacia la Historia Natural, en particular hacia los insectos y plantas. Sin embargo, a los 14 años debió interrumpir sus estudios secundarios para ingresar al taller de su padre, donde, como él mismo expresó, "pude aprender todos los procedimientos gráficos como fotografía, fototipia y grabados, que en aquella época experimentaban notables progresos" (Bruch, citado en Birabén 1943: 108).

Ya en este punto es bueno aclarar que muchas de las biografías sobre Carlos Bruch reproducen este relato autobiográfico sin ponerlo en cuestión (Lizer y Trelles 1943, 1947; Birabén 1943, entre otros). Por ello, aquí consideramos pertinente añadir que esta clase de relatos no depende de los sucesos mismos sino que más bien de la articulación de esos sucesos almacenados en la memoria y reproducidos mediante el recuerdo y su verbalización. Del mismo modo que, como señala Bourdieu (1986), en el relato biográfico la trayectoria de vida es presentada en forma consistente, plena de significado y propósito y dirigida con toda claridad hacia una meta, pasando por alto momentos de zozobra, azar y cambio (Farro 2009). 


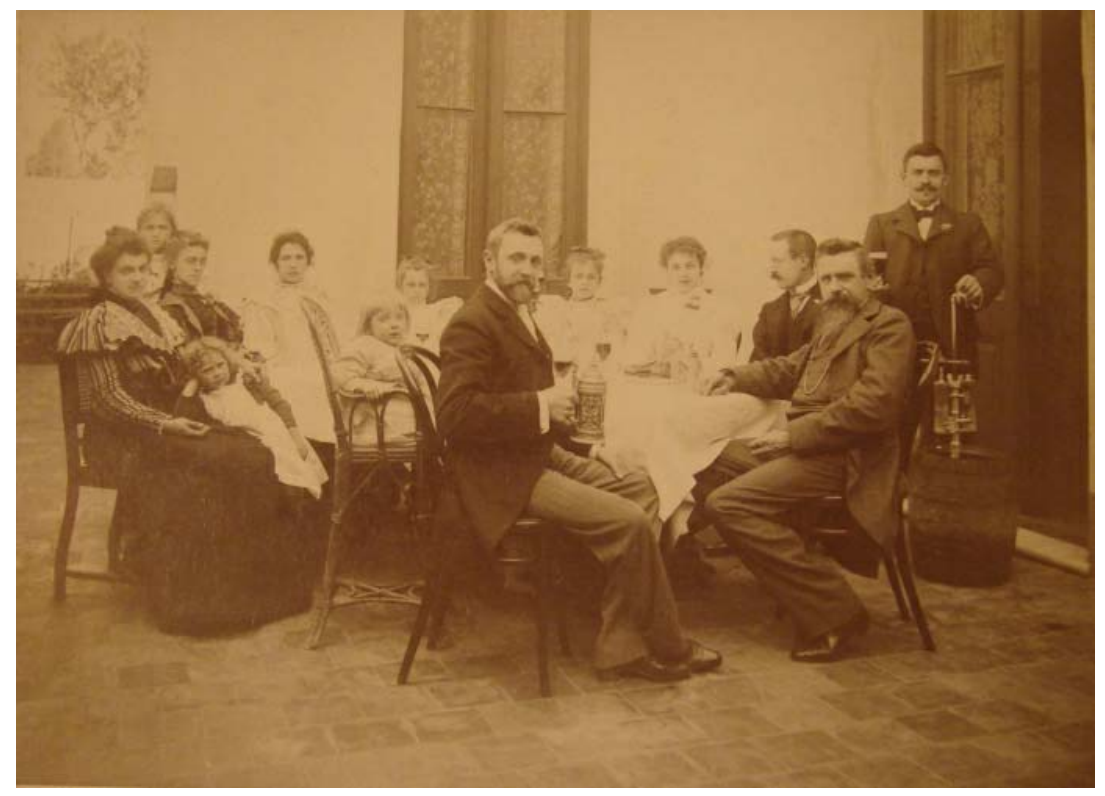

Figura 1. La familia Bruch en el patio de su casa en La Plata. Carlos y Chrsitian Bruch sentados en la cabecera de la mesa. (Autor desconodido, c. 1900)(Foto: gentileza María Luisa Sánchez Bruch)

Después de vender su taller de imprenta en Munich, Carlos y su padre -Christian Bruch (1842-1905)-, se embarcaron a la Argentina hacia finales de 1887. Para 1887 habían llegado a la Argentina un total de 1333 inmigrantes alemanes, mayoritariamente hombres adultos ${ }^{1}$. De ese total casi la mitad -611- fueron categorizados por las estadísticas de la época como "agricultores y colonos", mientras que en el rubro "artesanos y artistas" bajo el cual podrían haber sido inscriptos los Bruch², se declaraba el ingreso de un total de 116 personas (Latzina 1887: 509-510).

Por otra parte según los datos de este censo, también para el año de 1887 había en Buenos Aires un total de 149 fotógrafos, 315 encuadernadores, 139 grabadores, 345 litógrafos y 1211 tipógrafos (Latzina 1887:16-19) Refiriéndose a las imprentas dice este autor que en los 89 establecimientos tipográficos del municipio trabajaban 1211 tipógrafos, al tiempo que "Cada día aumentan nuevas máquinas estos establecimientos, pero el aumento de trabajo es mayor y todos rechazan continuamente trabajos importantes si el plazo con que se solicitan es breve. A la altura que ha llegado el arte tipográfico en esta capital lo dice claramente la impresión de este libro." (Latzina: 330) A juzgar por estas afirmaciones es posible pensar que los Bruch

\footnotetext{
${ }^{1}$ Según el censo de Latzina ese año ingresaron 1141 hombres, 128 mujeres, 38 niños y 26 niñas (Latzina 1887:506)

2 Las restantes categorías eran "comerciantes", "jornaleros", "diversos" y "sin profesión" (Latzina 1887: 510)
} 
habían llegado a Argentina para insertarse, en tanto obreros especializados ${ }^{3}$, en un mercado de trabajo que se hallaba en un constante crecimiento y aumento de la demanda laboral.

En este sentido, cabe señalar que su padre había sido contratado para trabajar en la Compañía Sudamericana de Billetes de Banco de Buenos Aires, la cual de acuerdo con Buonocore (1944) era una de las tres imprentas más importantes de esa ciudad. Una vez allí, sin embargo, Bruch había quedado, tal como el mismo lo decía,

"Desilusionado desde un principio por una perspectiva de trabajo poco halagüeña en este primer empleo e informado que en el Museo de La Plata, aún en construcción, se buscaba un joven entendido en trabajos fotográficos y procedimientos de reproducción, no vacilé en presentarme a su fundador Francisco P. Moreno." (Bruch citado en Birabén 1943: 108).

Nuevamente aquí debemos entender este elato en los términos señalados más arriba. De esta manera, Bruch padre e hijo llegaron a La Plata para trabajar en los talleres de publicaciones del museo. En ese sentido los Bruch se adaptaban a los planes originales de Moreno, tal era lograr producir una publicación científica con una calidad tipográfica de primer nivel. En el período comprendido entre los años 1888 y 1891 los Bruch estuvieron colaborando en la instalación y dirección de la imprenta del Museo, que comenzaría a funcionar completamente recién a principios de ese año ${ }^{4}$ (Farro 2009).

\footnotetext{
${ }^{3}$ Christian Bruch, el padre trabajaría en los talleres del museo como fotograbador mientras que su hijo Carlos lo haría como fotógrafo y fototipista.

${ }^{4}$ Entre 1891 y 1896 la dirección de los Talleres estuvo a cargo de Julio Vigier, ocupando este cargo Adolfo Wilcke desde 1897 hasta que se produjo el traspaso del museo a la órbita nacional en 1906.
} 
Figura 2. Personal y máquinas de los Talleres de Publicaciones del Museo de la Plata (Autor desconocido, c. 1900 Foto: AGN)

Sin embargo, entre los años de 1884 y 1889 la imprenta del Museo sólo publicó dos números del Boletín del Museo de La Plata que fue la primera publicación del Museo. Esta falta de producción generó gran parte del

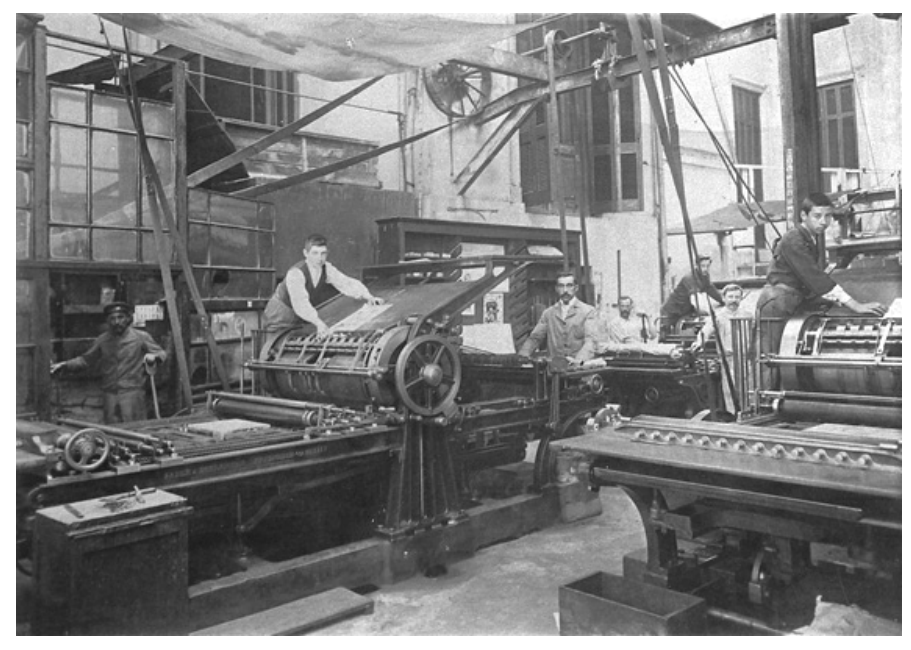
conflicto entre Moreno y Florentino Ameghino, vicedirector del establecimiento, que acusaba a aquel de promover la edición de discursos de propaganda de sí mismo antes que la obra científica del museo (Podgorny 2009) Esos boletines habían sido diagramados en los talleres de la imprenta del gobernador de la provincia de Buenos Aires, Manuel Gonnet ${ }^{5}$.

En esos talleres Carlos Bruch se desempeñó desde su llegada como fotógrafo y luego, desde 1894, también como fototipista ${ }^{6}$. Su padre ${ }^{7}$, a quien podemos ver en la Figura 3 , se ocupaba del fotograbado ${ }^{8}$. En el período que va desde 1888 hasta mediados de la

\footnotetext{
${ }^{5}$ Boletín del Museo La Plata. Informe preliminar de los progresos del Museo La Plata durante el primer semestre de 1888. Presentado al señor Ministro de Obras Públicas de la provincia de Buenos Aires por su Director Francisco P. Moreno. Buenos Aires: Establecimiento Tipográfico El Censor, 1888; y Boletín del Museo La Plata. Breve Reseña de los progresos del Museo La Plata, durante el segundo semestre de 1888. Por su Director Francisco P. Moreno. Buenos Aires: Establecimiento Tipográfico El Censor, 1889.

${ }_{7}^{6}$ AHPBA, Tribunal de Cuentas.

${ }^{7}$ Christian Bruch continuó trabajando como fotograbador del Taller de Publicaciones hasta su fallecimiento mientras desarrollaba su trabajo cotidiano en la tarde el 18 de marzo de 1905. Esto motivó no solamente que su puesto quedé vacante sino que se suspendiesen "todos los trabajos en que interviene la fotografía". (Carta de Adolf Wiecke, Director del Taller de Publicaciones del Museo al Ingeniero Angel Etcheverry, Ministro de Obras Públicas de la provincia de Buenos Aires, con fecha 18 de marzo de 1905. AHPBA, Ministerio de Obras Públicas, Letra T, N³7)

${ }^{8}$ El fotograbado es proceso de impresión fotomecánico del tipo intaglio. Este proceso fue inventado por Karl Klic (1841-1926) de Viena en 1879 y se basaba en el grabado fotoglífico de Henry Fox Talbot de 1852.Intaglio refiere a los métodos de impresión en los cuales las líneas, puntos, granos u otros elementos de placa de impresión, son hundidos en la placa a fin de que las depresiones se llenen con tinta de impresión. El fotograbado también conocido como grabado, fotograbado en aguatinta o proceso Talbot-Klic es el proceso intaglio mejor conocido y puede producir imágenes de alta calidad con una rica superficie mate sobre una amplia variedad de papeles (Hannavy 2008: 1112).
} 
década de 1890 Carlos Bruch se hallaba dedicado casi exclusivamente a sus trabajos en los talleres y la publicación de los primeros números de la Revista y los Anales ${ }^{9}$.

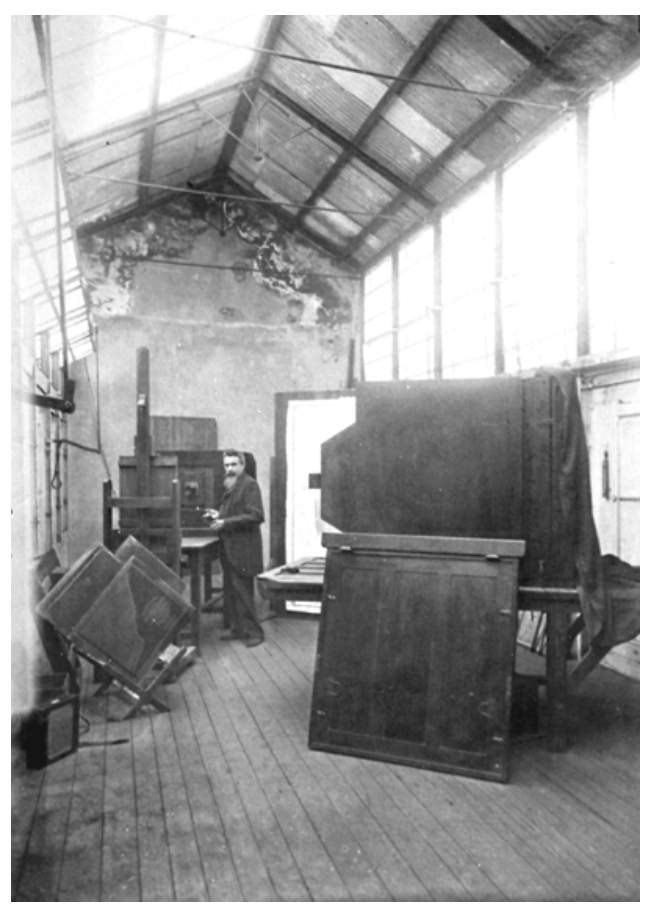

Figura 3. Christian Bruch en el estudio fotográfico contiguo a la imprenta del Museo de La Plata (Autor desconocido, c. 1900, AGN)

Hacia los primeros años de la década de 1890 las Bruch se mantuvo vinculado a distintos trabajos relacionados a su función en los talleres de publicaciones del museo como fotógrafo y fototipista que a la fotografía científica. En octubre y noviembre de 1891 Bruch había estado en casa del historiador Andrés Lamas (1817-1891) con el fin de "fotografiar su biblioteca" ${ }^{10}$ y en diciembre de ese mismo año también fotografió al naturalista alemán Hermann Burmeister (1807-1892) en Buenos Aires. En 1892 tomó fotografías en casa del anticuario e historiador Manuel Ricardo Trelles $(1821-1893)^{11}$.

En cuanto a la fototipia estuvo a cargo de la aplicación de este procedimiento desde 1890 hasta 1900, realizándolo en los primeros años en forma bastante artesanal ya que él mismo preparaba la gelatina sobre la que se imprimiría el negativo fotográfico a reproducir ${ }^{12}$.El frontispicio del primer número de la Revista del Museo de La Plata se

\footnotetext{
${ }^{9}$ De acuerdo con Farro los Anales (1890-1903) fueron concebidos para la publicación de trabajos específicos a cada una de las secciones, en formato in folio y profusamente ilustrados con planchas fotográficas y grabados de muy alta calidad; mientras que la Revista estaba destinada a contener los trabajos de menor extensión, en formato in $4^{\circ}$, también ilustrados con láminas, fotografías, mapas y dibujos, y con una frecuencia de aparición menos espaciada que los primeros. (Farro 2009)

${ }^{10}$ AHPBA; Tribunal de cuentas.

${ }_{11}^{11}$ AHPBA, Tribunal de cuentas.

12 En 1892 encontramos una facturación de gasto a nombre de Carlos Bruch donde se detalla la compra de cola de pescado por \$42, que se utilizaba para la preparación de la gelatina para la fotografía, además de otros gastos relacionados a la parte fotográfica (AHFMLP, Tribunal de Cuentas)
} 
incluyó una fotografía impresa por medio de la técnica de fototipia ${ }^{13}$, que de esa forma era utilizada por primera vez en Argentina (Lizer y Trelles 1937).

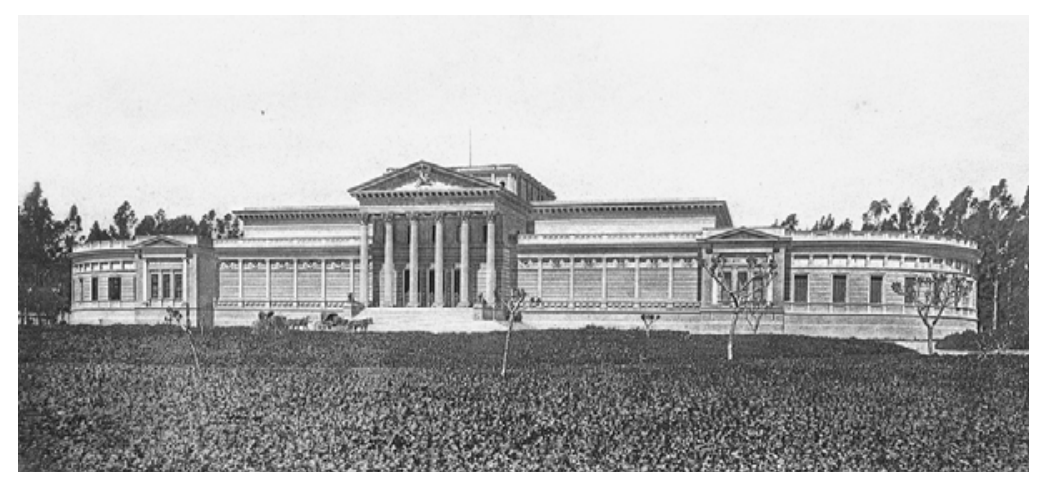

Figura 4. Frontispicio del primer número de la Revista del Museo de La Plata, 1890.

\section{La fotografía entomológica}

Hacia mediados de la década de 1890, y sin dejar sus obligaciones en los talleres de publicaciones, Bruch comenzaba a construirse un lugar en la planta científica del museo. A fines de 1895 donó su colección de coleópteros conformada por 50.000 ejemplares y que había traído consigo desde Alemania, aumentándola con ejemplares locales recolectados en los momentos libres que le dejaban sus tareas en los talleres del museo (Birabén 1945: 352). Al mismo tiempo Bruch ofrecía sus servicios gratuitos para atender la colección que él mismo había donado al no contar el museo con ningún empleado destinado para ello. Ambas ofertas fueron aceptadas por el director del museo quien lo nombró Encargado Honorario de la Subsección de Entomología mientras seguía realizando sus tareas habituales en los talleres (Memoria del Museo de La Plata 1896: 9). Esta donación muestra a su vez que el armado de las colecciones

\footnotetext{
${ }^{13}$ Este proceso de reproducción fotomecánica comenzó a desarrollarse desde la segunda mitad del siglo diecinueve. También conocido como fotolitografía, fue desarrollado en 1855 por Alphonse-Louise Poitevin, consistía en recubrir una piedra litográfica con albúmina bicromatada y exponerla bajo la luz de un negativo. Luego de lavar la albúmina no endurecida se imprimía con la piedra usando una prensa litográfica convencional. Una variante, el colotipo, daba copias de gran calidad y grano muy fino. En 1868 esta variante fue perfeccionada por Josef Albert, de Munich, quien utilizó gelatina bicromada, produciendo un grano fino al calentar la placa recubierta, con lo que la superficie de gelatina quedaba reticulada. Se conoció bajo el nombre de albertipo. (Newhall 2002: 251)
} 
del museo que Moreno llevaba adelante no era una actividad planificada de antemano sino que más bien respondía a las oportunidades que se presentaran en ese sentido.

Carlos Bruch, como ya vimos, había interrumpido sus estudios secundarios para especializarse en distintas tareas gráficas realizadas en la imprenta de su padre y que fueron las que en última instancia lo trajeron a la Argentina. La donación y el ofrecimiento para encargarse de esos materiales en forma honoraria resultaron en una buena oportunidad para el museo de sumar una nueva colección y garantizar su cuidado sin erogación alguna. En ese sentido la colección de coleópteros buscaba en cierta forma certificar su idoneidad para recolectar, clasificar y organizar materiales, la que junto a su conocimiento y manejo de las artes gráficas le permitiría en ocasiones desempeñarse como naturalista viajero de esa institución. Por otro lado, venía relacionándose con Carlos Berg (1843-1902), naturalista especializado en entomología y director del Museo Nacional de Buenos Aires desde mayo de 1892, tras el retiro de Hermann Burmeister. Bruch se vinculó con Berg desde al menos finales de 1893, enviándole material para determinar, no solamente entomológico sino también ictiológico, dejando para Berg los ejemplares duplicados ${ }^{14}$, por lo cual la bibliografía más tradicional lo considera uno de sus discípulos junto a Angel Gallardo (1867-1934). (Furlong Cardiff 1964; Lizer y Trelles 1924)

Como veremos en este capítulo Bruch tomó imágenes de los más variados temas, paisajes, poblaciones indígenas y sitios arqueológicos, imágenes que tienen fundamentalmente un valor documental ${ }^{15}$ que aquí deseamos resaltar. Sin embargo, una parte importante de la actividad de Bruch como fotógrafo está vinculada a la fotografía de insectos, a cuyo estudio se dedicó con gran placer, logrando imágenes muy apreciadas -en tanto tuvieron amplia circulación y fueron utilizadas por muchos de sus pares- "con una aparato fotográfico arcaico e improvisado", al decir de su discípulo y amigo, Carlos Lizer y Trelles (1943).

\footnotetext{
${ }^{14}$ Así lo podemos inferir a partir de la correspondencia científica entre Bruch y Berg que se conserva en el Archivo de la División Entomología del Museo Argentino de Ciencias Naturales "Bernardino Rivadavia".

${ }^{15}$ En un sentido similar al que lo otorga Newhall a este género fotográfico (Newhall 1938)
} 
Luego del fallecimiento de Bruch, la Revista de la Sociedad Entomológica Argentina publicó varios artículos de distintos científicos argentinos en homenaje a su memoria. Además de las biografías y resúmenes de la obra de Bruch, encontramos una interesante comunicación escrita Miguel Jörg, donde se destaca que "su genialidad artística [se refiere a Bruch] trasunta en su obra científica a través de dos expresiones plásticas: su dibujos y sus fotografías" (Jörg 1943:85). Para ese autor Bruch era uno de los más valiosos fotógrafos de insectos; prueba de ello eran su "extraordinaria manualidad" y "paciencia inagotable" por medio de las cuales pudo obtener excelentes resultados a partir de los recursos más elementales.

Durante más de 30 años Bruch había tomado fotografías entomológicas utilizando la misma cámara, que era un "remedo increíble de las cámaras verticales de Hegener y Romeis que se utilizan en la macro y microfotografía científica" (Jörg 1943: 87) el aparato vertical que conformaba es cámara había sido comprado por el Dr. Carlos Spegazzini (1838-1926), amigo personal de Bruch, en un "cambalache" por la suma de $\$ 10$, y para poder ser utilizado Bruch le agregó un ampliador Stegmann ${ }^{16}$ con un chasis de $9 \times 12 \mathrm{cms}$.

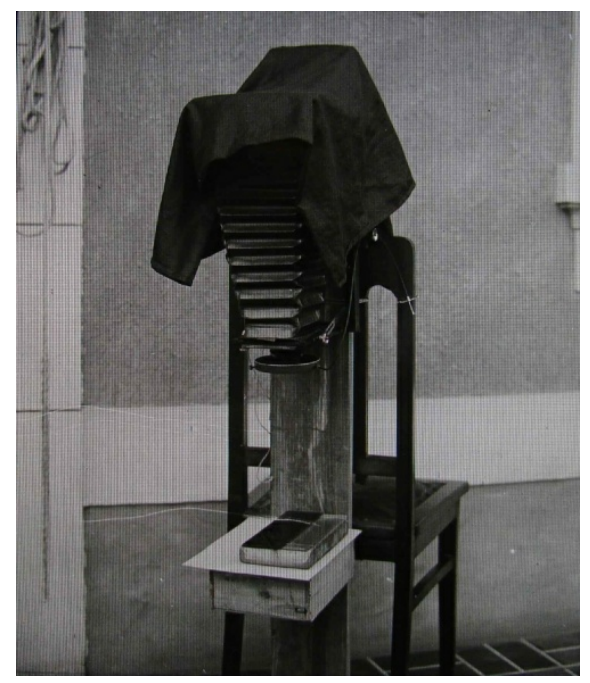

A fin de alcanzar los aumentos necesarios Bruch utilizó tres lentes diferentes:

-Zeiss Doble anastigmático, f:150 mm, para fotografías de hasta 4 aumentos (4x).

- Leitz Micro-Summar de $42 \mathrm{~mm} .$. f:4,5 para fotografías de hasta 10 aumentos, y

- Leitz Micro-Summar 24 mm., f:4,5 para fotografías de hasta 30 aumentos.

Figura 5. "Dispositivo para tomar las fotos in vivo. Colección C. Bruch". (C. Bruch, s/f.) (MACN)

\footnotetext{
${ }^{16}$ Antigua ampliadora de foco fijo con portaplaca.
} 
Con esta improvisada cámara, y su "extraordinaria manualidad unida a su paciencia inagotable" (Jörg 1943: 87), Bruch logró imágenes entomológicas muy bien consideradas por sus colegas en el país y en el exterior. Para obtener una buena fotografía entomológica Bruch sostenía que el secreto no estaba en la cámara, sino que el éxito de esta tarea dependía del arreglo del insecto a fotografiar, su centrado y colocación simétrica y plana, el arreglo de los miembros y articulaciones y de la iluminación uniforme.

\section{La "Colección Carlos Bruch"}

En diciembre de 1910, Carlos Bruch (1869-1943), ofrecía en venta al Museo de La Plata un lote de 542 "positivos de proyecciones ${ }^{17}(\ldots)$ de $1^{\circ}$ calidad" que incluían:

"vistas de paisajes, gentes, animales y costumbres del país, tomadas en gran parte personalmente durante los viajes a la Patagonia y provincias del Norte. Entre dichas vistas hay muchas inéditas y otras que son de verdadero interés para los fines de la enseñanza."18

Bruch, quien por entonces se desempeñaba como encargado de la sección zoología y docente del Museo de La Plata, donde dictaba clases de zoogeografía, entomología general y un curso de fotografía aplicada a las ciencias naturales ${ }^{19}$, adjuntó a esta carta una lista detallando los diferentes lugares del país donde esas imágenes habían sido obtenidas. La lista completa de imágenes ofrecidas comprendía:

- $\quad$ "200 positivos viajes a la Patagonia. De Valparaíso a Puerto Mont, costa chilena, pueblos hasta Puerto Mont; viaje hasta el Lago Nahuel Huapi; numerosas vistas del Tronador y del Nahuel Huapi. Viaje desde el Neuquén hasta el Nahuel Huapi por el Río Limay; viaje al Lago Lácar. Viaje desde el Nahuel Huapi hasta el Lago Buenos Aires por la Colonia 16 de Octubre y vuelta por el Senguer hasta Comodoro Rivadavia.

\footnotetext{
${ }^{17}$ Diapositivas de vidrio que se proyectaban utilizando una linterna mágica.

${ }_{18}^{18}$ Carta de Bruch a Samuel Lafone Quevedo, La Plata 20 de diciembre de 1910, AHFMLP.

${ }^{19}$ Carlos Bruch, legajo personal, s/f, AHFMLP.
} 
- Vistas aisladas de regiones del Lago Argentino, Última Esperanza (ventisqueros).

- $\quad 22$ positivos de vistas selectas de Santa Cruz, paisajes y gentes (Indígenas).

- 50 vistas únicas de paisajes y animales de las Islas de las Orcadas.

- 90 positivos Viaje de Jujuy por la quebrada Humahuaca hasta Santa Catalina, Garrapatal y San Pedro y vuelta por la Quebrada del Toro.

- $\quad 40$ positivos de tipos indígenas: Chiriguanos, Tobas, Chorotes y Chiriguanos.[SIC]

- 50 positivos viaje a Asunción, Villa Rica, Posadas, Alto Paraná, Iguazú y Alto Iguazú.

- 40 positivos de ruinas y petroglifos indígenas de Catamarca y Tucumán, usadas en la Conferencia del Congreso de Americanistas.

- 50 positivos, viaje por las provincias de Tucumán y Catamarca; paisajes, pueblos, ruinas y costumbres."20

Esta colección estuvo conformada por "positivos", la mayoría de ellos en formato 8x8 ${ }^{21}$, sobre los cuales Bruch remarcaba su "verdadero interés para los fines de la enseñanza". En este punto debemos recordar que esta clase de imágenes estaban destinadas a ser utilizadas en tanto en las clases como en las conferencias dirigidas al

\footnotetext{
${ }^{20}$ Carta de Carlos Bruch a Samuel Lafone Quevedo, 20 de diciembre de 1910. AHFMLP.

21 Este era el formato más corriente para las diapositivas de vidrio que se utilizaban en las denominadas proyecciones luminosas. Desde los últimos años de la década de 1880 hasta bien entrado el siglo XX la producción de este tipo de placas se realizaba frecuentemente por impresión de contacto donde el negativo era del mismo tamaño que el positivo buscado, una vez que la placa había sido expuesta, generalmente a la luz del día, y revelada, el lado de la emulsión era protegido con un vidrio cobertor y los bordes se encintaban con passé partout (Hannavy 2008: 335).
} 
público en general que se venían dictando en el museo desde $1906^{22}$. En estas conferencias con "proyecciones luminosas" se utilizaba la "linterna mágica" un artefacto visual desarrollado en el siglo XVII, que se había perfeccionado desde la invención de la fotografía ${ }^{23}$ y cuyo se hallaba bastante extendido para fines del siglo $X I X^{24}$. Estas exposiciones servían para que los estudiantes adquieran entrenamiento en la visualización de los objetos, lo que hacía posible el trabajo taxonómico de atribuir una palabra a un objeto (García 2005: 48). Además y tal como señala esta última autora el aspecto educativo de las demostraciones con linterna mágica se combinaba con el potencial del entretenimiento, especialmente en las conferencias de extensión universitaria a cargo de profesores y alumnos avanzados, donde era esencial asegurar que la exposición fuera suficientemente pintoresca y llamativa para mantener la atención de la audiencia (García 2005: 38).

En el Archivo Histórico y Fotográfico como en el Departamento de Arqueología del museo $^{25}$ se conservan algunas diapositivas de vidrio con una leyenda que dice "Colección C. Bruch" y cuyo tema y formato coinciden con lo manifestado en la lista que

\footnotetext{
${ }^{22}$ En setiembre de 1906 un periódico platense anunciaba: "El señor Enrique S. Delachaux dará esta tarde á las dos y media una conferencia sobre los terremotos de Chile. Al efecto se ha habilitado una de las grandes salas del museo, la en que estuvo [SIC] depositada la locomotora La Porteña; sala que permite conseguir la penumbra necesaria para que tengan brillo las proyecciones luminosas que ilustrarán la interesante conferencia. La concurrencia promete ser numerosa y no faltará tampoco el concurso del bello sexo." Diario El Día , "La conferencia de hoy en el Museo", 8 de septiembre de 1906.

23 Según lo describe Eduardo Russo: "Sus antecedentes, según documentos, parecen remontarse a la antigüedad clásica. Ya en 1646, el padre Athanasius Kircher dejó registro del concepto básico y de una numerosa serie posible de esos aparatos de proyección por imágenes por medio de una fuente de luz y una lente en una obra de lovecraftiano título: Ars Magna Lucis et Ombrae. Como divertimento, la linterna mágica poseía un costado para el asombro y otro para el espanto; la difusión del tratado de Kircher acompañó el furor por las linternas mágicas en la segunda mitad del siglo XVII y todo el siguiente, con versiones hogareñas y otras más imponentes para espectáculos itinerantes. Las más ingeniosas hasta podían dar la impresión de movimiento en sus imágenes por medio de transparencias superpuestas y desplazables. Unido a ellas se expandió el espectáculo de las fantasmagorías, con sus historias pavorosas que aterrorizaron al público durante un par de centurias, en un esfuerzo por mostrar la dimensión espectral en la imagen que acaso sea el mayor antecedente como espectáculo del cine de terror. El artilugio fue llamativamente perfeccionado en Inglaterra, paralelamente al invento de la fotografía. Juegos de lentes, varias imágenes movibles, efectos de cierre y apertura, junto a la posibilidad de usar fotos registradas sobre vidrio -entre otras capacidades- hacían que una linterna mágica maniobrada por un operador hábil y un buen narrador -a menudo reunidos en una misma persona- convirtiera a cada sesión en un show memorable, donde relatos fantásticos o maravillosos permitían a menudo la visión de lo imposible a los fascinados espectadores." (Russo 1998: 145)

${ }^{24}$ Los usos de este artefacto eran diversos ya que iban desde el divertimento hasta la enseñanza pasando por su aplicación en la evangelización (Martínez 2010).

${ }^{25}$ Hallamos también algunas diapositivas de este grupo en el Archivo Fotográfico del Museo Etnográfico de la Facultad de Filosofía y Letras de la Universidad de Buenos Aires. Estas diapositivas, 8 en total, podrían corresponder al grupo de "40 positivos de tipos indígenas", lo que hace probable que se encuentren allí al haber sido utilizadas por Robert Lehmann-Nitsche en el curso de antropología dictado en esa institución.
} 
transcribimos ${ }^{26}$. Por otra parte podemos afirmar que salvo en el caso de las imágenes pertenecientes a las Islas Orcadas y de las "vistas aisladas" tomadas en el Lago Argentino y Última Esperanza donde Bruch nunca había estado, el resto de las imágenes fueron tomadas por él mismo ${ }^{27}$, en el contexto de los viajes que realizó entre 1896 y $1908^{28}$.

Atendiendo a la trayectoria de Carlos Bruch en el Museo de Plata podemos observar que entre 1896 y 1908 participaría de varios de los distintos viajes con múltiples propósitos que se emprendían desde el museo. A partir de la década de 1910 Bruch empezaría a orientarse en forma exclusiva a los estudios entomológicos y los viajes que realizara desde alrededor de mediados de esa década hasta su retiro irían en ese sentido. Por ello nos atrevemos a afirmar que la colección que aquí tratamos había sido producida en un período de su actividad en esa institución que había llegado a su fin.

Luego de que donara su colección entomológica al museo a fines de 1895 Bruch emprendería su primer viaje por encargo de esa institución. Hacia finales del año siguiente salió de La Plata rumbo a la región de Catamarca y Tucumán, siendo el primero de una larga lista de viajes que realizaría, como empleado del Museo de La Plata en algunos casos, y como fotógrafo de la Comisión de Límites con Chile ${ }^{29}$ en

\footnotetext{
${ }^{26}$ Su número, sin embargo, no supera las diez imágenes haciendo que esta colección se constituya en un ejemplo más de las ausencias en el Archivo Histórico y Fotográfico del museo tratadas en el capítulo anterior.

${ }^{27}$ Debemos notar además que Bruch se refiere a estos dos grupos de imágenes como "vistas" mientras que utiliza el término "positivos" para el resto de la colección, lo que podría estar indicando que ellas no hayan sido producidas originalmente por ese fotógrafo.

${ }^{28}$ Así detallaba Bruch su itinerario: "Viajes científicos realizados: 1. 1896. Primer viaje de exploración a la provincia de Catamarca. 1897-1898 viaje a Chile y Patagonia, región de los Lagos con el doctor Leo Wehrli. 1902. Con la Comisión arbitral inglesa 1903. Con el Dr. F. P. Moreno y Dr. Steinmann prov. de Jujuy, región de Puna. 1904. Con el Dr. F. P. Moreno a Misiones y Paraguay. 1906. Con el Dr. R. Lehmann-Nitsche, Indígenas de San Pedro, Jujuy. 1907 y 1908. Exploraciones arqueológicas de Tucumán y Catamarca. 1912. A la provincia de Catamarca, Dep. de Andalgalá. 1914. Exploración de San Luis, Alto Pencoso y Sierra del Gigante.1914. Viaje a Miramar con el Dr. Luis M. Torres. 1916. Sierra del Tandil y de la Ventana. 1918. Viaje a la región de Villaguay de Entre Ríos. 1923. Excursión al Chaco de Santa Fe (Fives Lille). A estos viajes se agregan las largas y continuadas permanencias en las Sierras de Córdoba, efectuadas por cuenta propia y que sirvieron para el estudio de la fauna entomológica y a la botánica de estas regiones (desde 1919 hasta la fecha)" (Carlos Bruch, Legajo personal, s/f, AHFMLP.)

${ }^{29}$ A pesar de que Lizer y Trelles (1924) sostiene que para 1894 Moreno había nombrado a Bruch como fotógrafo de la Comisión de Límites con Chile, los primeros indicios que encontramos sobre su actuación en este ámbito se remontan a fines de 1897 y principios de 1898 cuando estando en viaje con el geólogo Leo Wehrli por la zona cordillerana de las actuales provincias de Neuquén y Río Negro, se unieron en sus recorridos por la zona a la VII Subcomisión a cargo del ingeniero Lehmann (Wehrli, 1898; Informe Lehmann, AHCA)
} 
otros. Fue en el contexto de estos y otros viajes ${ }^{30}$ que se sucedieron hasta 1908 donde Bruch produjo un conjunto de imágenes fotográficas que van desde las "instantáneas" que representan la cotidianeidad de los viajes científicos hasta las "vistas" o "panorámicas" tomadas como fotógrafo de la Comisión de Límites con Chile.

\section{Un "fotografista" ${ }^{31}$ en viaje por el Noroeste}

Entre noviembre de 1896 y enero de 1897 Bruch realizó su "primer viaje de exploración a Catamarca"32, comisionado por el Museo de La Plata, donde recolectó fauna, flora y restos arqueológicos de las regiones de Hualfín y Andalgalá además de registrar sus observaciones por medio de notas, dibujos y fotografías (Bruch 1904a). Moreno, siempre atento a cuidar y a construir continuidades (Farro 2009, Podgorny 2006), relataría que con ello el museo retomaba las exploraciones que su director había realizado a esa provincia y que habían sido descontinuadas debido a problemas económicos (Moreno 1890). El naturalista viajero Adolf Methfessel (1836-1909) ${ }^{33}$, quien había estado trabajando para el museo en aquella región entre 1888 y $1890^{34}$, había renunciado a su puesto en el museo en 1895 para regresar a Suiza.

Además de explorar las regiones Hualfín y Andalgalá, Bruch hizo una recorrida durante enero de 1897 por los Valles Calchaquíes. Los objetos recolectados en este viaje irían a ser exhibidos en la Exposición Internacional de Paris de 1900, sin embargo, la colección arqueológica que había logrado reunir durante su estadía en Hualfín se perdería en el traslado, tal como lo relata Bruch "al pasar los arrieros con la carga por la estrecha quebrada de Amanao, habían sido sorprendidos por una enorme creciente

\footnotetext{
${ }^{30}$ Bruch, no incluye entre sus "viajes científicos" (Bruch, Legajo personal) los trabajos realizados con el antropólogo Robert Lehmann-Nitsche en la Exposición Nacional de 1898 y en el Asilo Correccional de Mujeres regenteado por las Hermanas del Buen Pastor en 1899, debido tal vez a que ambos tuvieron lugar en la cercana ciudad de Buenos Aires y no hayan ocupado más de una jornada de trabajo (Lehmann-Nitsche 1904a).

${ }^{31}$ Bruch incluyó este término en una carta escrita a Lehmann-Nitsche desde Hualfín en 1908, según Escobar (2000) esta término es producto del contacto del idioma español con el quechua y utilizado en la región andina en lugar de "fotógrafo".

${ }^{32}$ Carlos Bruch, legajo personal, AHFMLP.

${ }^{33}$ Felix Ernst Adolf Methfessel, nació en Berna en 1836 donde estudió dibujo y pintura, graduándose como arquitecto de jardines en la escuela Sans Souci, en Postdam, llegando a la Argentina en 1864.

${ }^{34}$ Como naturalista viajero del museo, Methfessel también acompañaría a Juan Bautista Ambrosetti en su segundo viaje por el Iguazú y Alto Paraná (Ambrosetti 1894)
} 
que arrebató con su fuerza casi todas las muías y el cargamento que llevaban." (Bruch 1904: 13) (Cfr. Podgorny 2008)

Bruch estuvo entre los primeros naturalistas viajeros ${ }^{35}$ que visitaron Hualfín, una localidad particularmente estudiada por la arqueología argentina durante el siglo XX. El valle de Hualfín se fue transformando en una de las zonas más visitadas de excavación de tumbas indígenas y fuente de antigüedades, a raíz del valor creciente de las llamadas "antigüedades calchaquíes" (Podgorny 2008)

Figura 6. "Quebrada de Amanao (Catamarca) Colección C. Bruch". (C. Bruch, s/f, Diapositiva de vidrio, $8 \times 8 \mathrm{~cm}$.) (DAMLP)

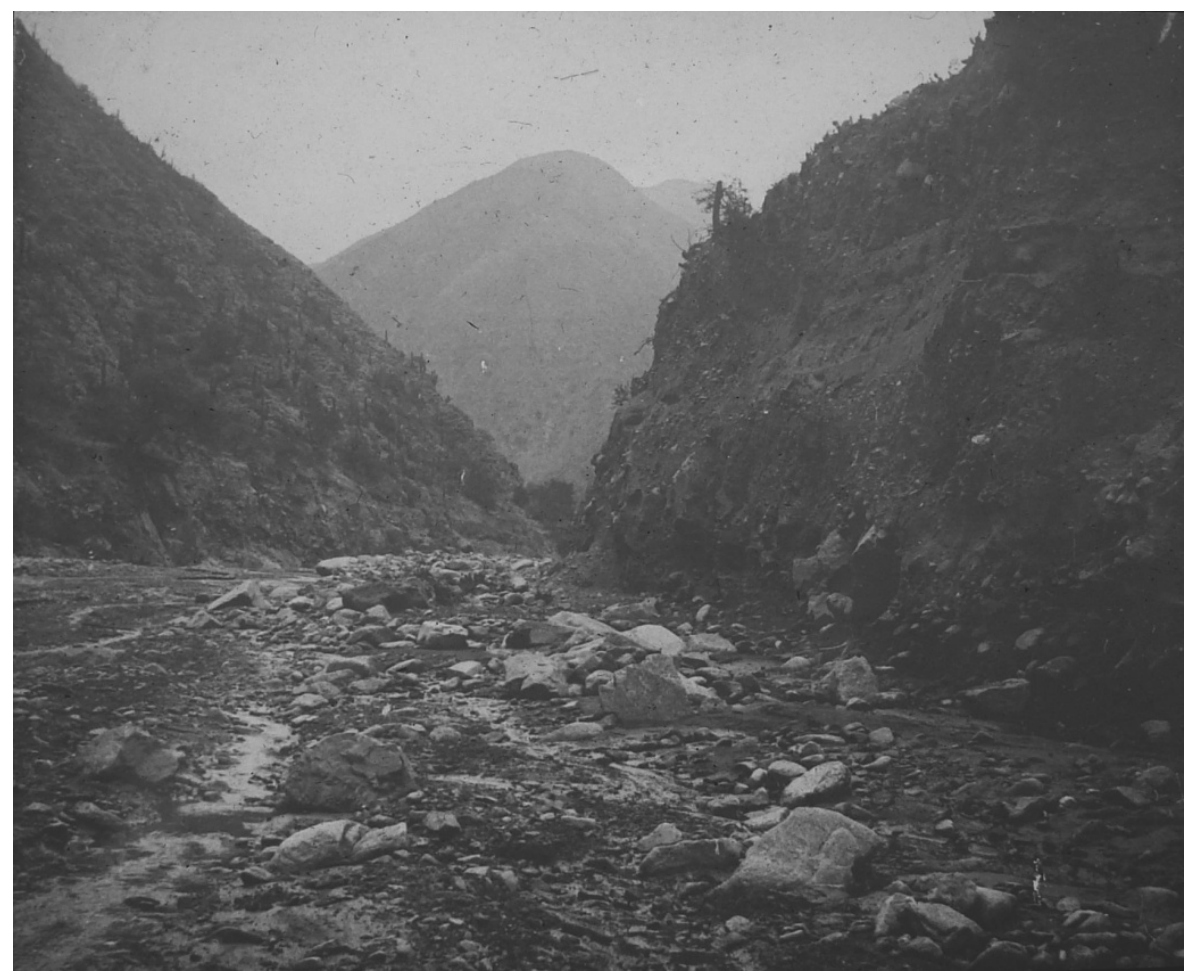

Además de utilizar la cámara fotográfica para registrar las observaciones relacionadas específicamente con las actividades científicas que había ido a realizar allí, Bruch también se preocupó por capturar el paisaje catamarqueño que, como el mismo decía dejaba "bien impresionado" al viajero:

35 Respecto a los trabajo de Bruch en Catamarca decía Samuel Lafone Quevedo: "Ha logrado sacar cráneos, alfarería, objetos de cobre y madera hallados in situ; ha hecho dibujos y sacado fotografías de todo y en todos los estados del trabajo; en fin, ha hecho exploración verdaderamente arqueológica (...)Como objetos hermosos en cualquier parte se hallará cosa mejor que lo que lleva Bruch; pero lo de ese explorador es arqueología, aquello sería bric á brac.[La Nación, 27 de febrero de 1897] 
"El 18 de Enero llegué por segunda vez a Hualfín. Los álamos y sauces, característicos de los pueblos catamarqueños, forman allí los cercos de vastas propiedades y labranzas que se extienden á ambos lados del río; las serranías lejanas y el Cerro Colorado que se destaca encima de las terrazas fluviales como una inmensa fortaleza, todo contribuye á dar al paisaje árido y monótono un aspecto pintoresco que deja al viajero bien impresionado de su visita. Y si se dá luego una mirada alrededor de aquellas propiedades, pronto se apercibe de las ruinas y cementerios, últimos vestigios de sus primitivos dueños; restos de una tribu muy numerosa: los antiguos Hualfines." (Bruch 1904a: 14)

Estando justamente en Hualfín también tuvo oportunidad de tomar fotografías a los habitantes del lugar, que fueron publicadas en "Descripción de los sepulcros calchaquíes" (Bruch 1904a), con la intención de ofrecer una "pequeña idea gráfica de la población quichua que hoy en día habita la regiones calchaquís y á la cual podemos considerar como descendiente de aquella nación civilizada." (Bruch 1904a: 26) En el texto que acompaña a estas imágenes Bruch realiza una detallada descripción de las características físicas de los retratados a partir de las imágenes fotográficas ${ }^{36}$, que pueden considerarse como las primeras fotografías antropológicas (Ver Introducción) tomadas por Carlos Bruch.

\footnotetext{
${ }^{36}$ Lo más interesante de este registro visual, según con el autor y en acuerdo a las preocupaciones de la antropología física, resultaban las características del cráneo del hombre representado en la Figura 6. Se trataba de un cráneo alto y estrecho, producido por deformación y denominado hypsicéfalo. Estas características craneanas daban, según el propio Bruch, un valor especial a las imágenes ya que: "Es siempre interesante observar en el vivo esta forma de cráneos" (Bruch 1904a: 26).
} 
Figura 7. "Tipos calchaquís, habitantes de Hualfín." (Bruch 1904a, Lámina IV)

En 1903 una reseña sobre este trabajo firmada por el abogado Luis María Torres (1878-1937) decía "no estamos conformes en todo con el señor Bruch; y nuestra disidencia consiste en que, esos tipos que nos presenta en la lámina III $[\mathrm{SIC}]^{37}$ no son Calchaquíes sino Quichuas, actuales habitantes de los valles Calchaquíes." (Torres 1903: 96). A pesar de que muchos trabajos inisisten en que los viajeros del siglo XIX desconocían la existencia de indígenas contemporáneos, las fotos y los

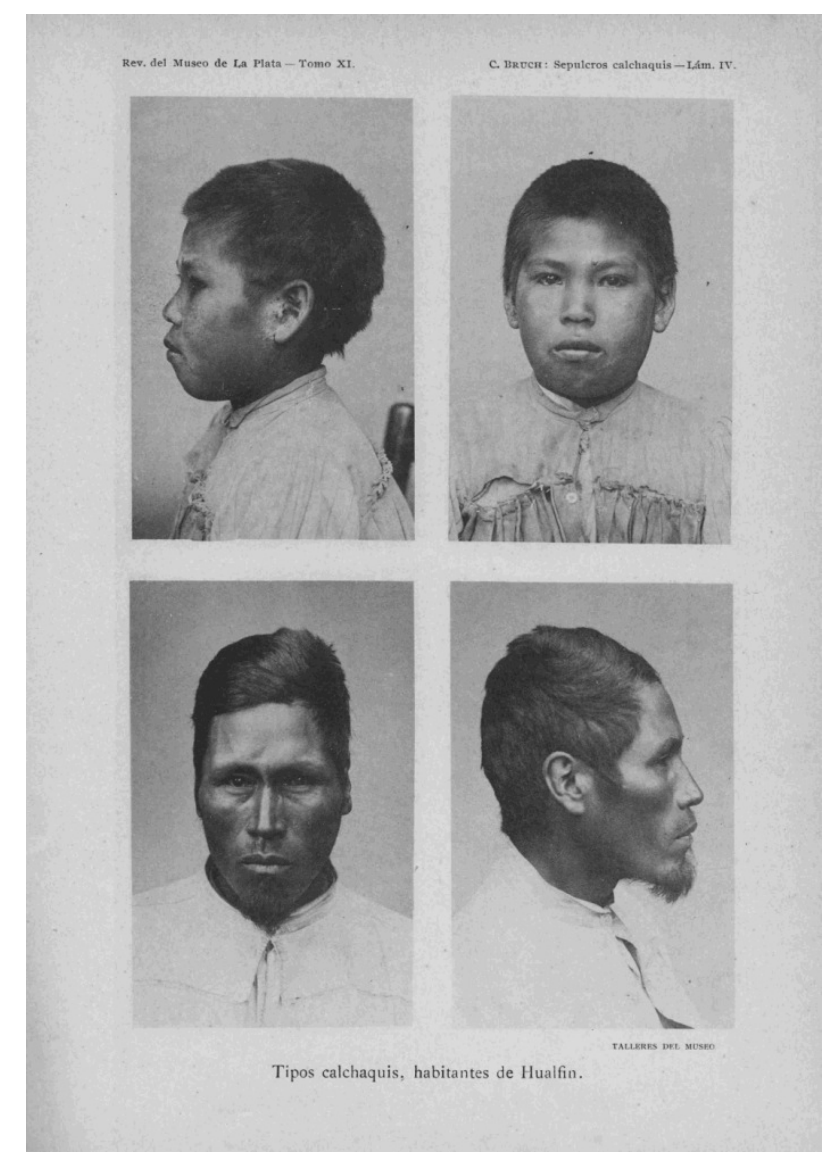
comentarios de Bruch revelaban todo lo contrario. Los valles no solo estaban poblados de indígenas: se los consideraba además como los descendientes de los constructores de las ruinas. El comentario de Torres, por otro lado, invitaba a no simplificar la historia colonial y de poblamiento de esos valles: los habitantes actuales eran el resultado de una larga historia de traslados y reemplazos por lo que no se podía saber a ciencia cierta qué tipo de relación podría haber habido entre los grupos actuales y los desaparecidos constructores de las ruinas.

Al emprender este viaje por Tucumán y Catamarca, Bruch había dejado su puesto en los talleres de imprenta siendo nombrado Jefe de la Sección Zoológica en 1900 y profesor de zoología desde 1906. El principal objetivo de esta excursión fue el de recolectar material arqueológico de esa región, no solamente a través de las

\footnotetext{
${ }^{37}$ En realidad los "tipos calchaquíes" fueron incluidos en la lámina IV, la lámina III presenta un croquis del sitio arqueológico donde trabajó Bruch.
} 
excavaciones, observaciones y registro que efectuara en el campo sino también adquiriendo colecciones locales. Al igual que en su primer viaje a esta región y debido en parte a la imposibilidad de poder adquirir colecciones locales por lo elevado de los precios o simplemente porque otros se le habían adelantado Bruch decidió realizar excavaciones por su cuenta: "Ya que no he podido conseguir nada de colecciones y disponiendo de tiempo, pienso de hacer aquí algunas excavaciones en debida forma. Creo que mas vale una pequeña colección sacada de esta manera que una grande sin los datos precisos. ${ }^{138}$

Junto con los estudios arqueológicos Bruch también pudo formar colecciones zoológicas y botánicas además de realizar observaciones y registros sobre la geología del lugar ${ }^{39}$. Por otra parte, como él mismo lo señala, buscó "reunir (...) todos los datos iconográficos á mi alcance que, además de su valor documentario, servirían en parte para ilustrar mis descripciones." (Bruch 1911: V). Este registro iconográfico había sido planteado de antemano, cuando Bruch presentó el proyecto para realizar este viaje al director del Samuel Lafone Quevedo el 8 de enero de 1908, donde se proponía, entre otras tareas “... obtener también vistas fotográficas de todos los puntos más interesantes. Quiero hacer presente, que las máquinas fotográficas, como útiles para colecciones entomológicas que llevaré en este viaje son de mi propiedad." ${ }^{40}$ De esta forma Bruch pretendía dejar sentado que todas las imágenes fotográficas y los insectos que obtuviera en esa expedición serían de su propiedad, sin poder el Museo reclamar derechos sobre ellas. Algunas de esas fotografías las utilizó en sus publicaciones, como la Figura 8 más abajo, mientras muchas otras fueron las que ofreció en venta al museo en 1910.

\footnotetext{
${ }^{38}$ Carta de Carlos Bruch a Samuel Lafone Quevedo, Hualfin, 26 de febrero de 1908 (AHFMLP)

39 "Informe preliminar sobre la expedición a las Provincias de Tucumán y Catamarca efectuada en Febrero y Marzo 908 por el Jefe de la Sección Zoológica", Carlos Bruch, abril de 1908 (AHFMLP)

${ }^{40}$ Carta de Carlos Bruch a Samuel Lafone Quevedo, La Plata, 1 de enero de 1908. (AHFMLP)
} 
Figura 8. Londres, Catamarca (C. Bruch, 1907-08) (Negativo de vidrio, $9 \times 12 \mathrm{~cm}$.) (ADAMLP)

Una reproducción de esta fotografía fue publicada por Bruch en 1911 con el siguiente pie de foto: "Vista parcial de la actual población de Londres" (Bruch 1911: 164). A la derecha de la imagen puede verse la Iglesia de San Juan Bautista, Londres.

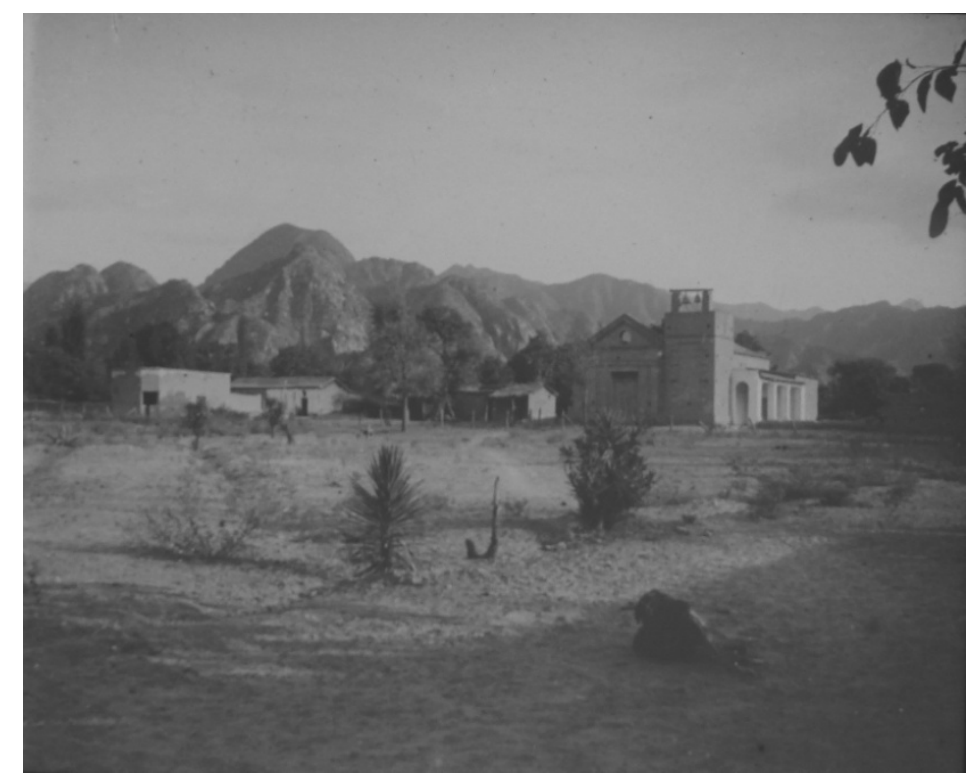

Los viajes a la Patagonia, la Puna y Misiones

Luego de su primer viaje a Catamarca entre los años 1896-97 Bruch acompañaría al geólogo suizo Leo Wehrli (1870-1954) quien se había incorporado al museo en 1896 en un viaje por la Patagonia. Entre noviembre de 1897 y abril de 1898, durante un trayecto de aproximadamente 6 meses, viajan a la zona comprendida entre el Lago Nahuel Huapi y Junin de los Andes. Francisco Moreno había encomendado a este geólogo, su colega y compatriota, Carl Burckhardt (1869-1935), la realización de dos perfiles geológicos transversales de la cordillera argentino-chilena a la altura de las localidades de Malargüe (Mendoza) y Las Lajas (Neuquén) (Riccardi 2008) ${ }^{41}$.

\footnotetext{
${ }^{41}$ Estos perfiles y el estudio de los invertebrados fósiles en ellos hallados, permitieron establecer la sucesión estratigráfica de la región y sus variaciones faciales y estructurales en sentido oeste-este. (Riccardi 2008).
} 


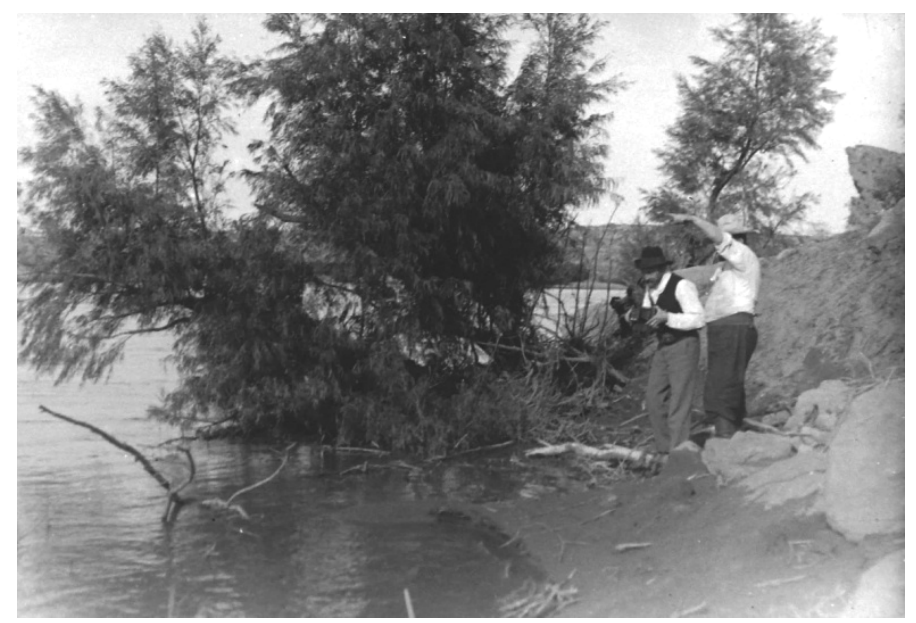

Figura 9. Carlos Bruch fotografiando (Autor desconocido, s/f) (Negativo de vidrio, $9 \times 12 \mathrm{~cm}$.) (DAMLP)

Esta expedición geológica debía, según las instrucciones, dirigirse al Lago Nahuel Huapi y hacia la región situada entre ese lago al sur y el Bio Bio al norte (Burckhardt 1898: 199). Wehrli salió de La Plata el 24 de noviembre de 1897 para pasar a Chile por Mendoza y Uspallata y comenzar su trabajo en el extremo oeste de la costa del Pacífico (Wehrli 1898: 223). En la tarde del 2 de diciembre dejaron Santiago para embarcarse enseguida para Valparaíso hacia Puerto Montt, que era el punto de partida de la expedición. Sin embargo, estando en Valparaíso, Burckhardt enfermó y debió permanecer en esa ciudad durante dos meses hasta restablecer su salud. Esto motivó que Wehrli continúe con la travesía sin la compañía de Burckhardt pero contando con Carlos Bruch como asistente, el "fotógrafo alemán del Museo de La Plata" como él lo llamó, quien lo secundó durante todo el viaje. (Wehrli 1898: 223-24).

Hacia fines del mes de diciembre llegan a Puerto Moreno y se trasladan a la casa del colono alemán José Tauschek en las cercanías del poblado de San Carlos ${ }^{42}$ (Figura 10). En ese punto Wehrli y Bruch se encuentran con algunos miembros VII Subcomisión demarcadora de límites, con M. C. G. Lehmann, primer ingeniero auxiliar $^{43}$, decidieron trabajar juntos (Wehrli 1899). Se conservan de esta expedición varias imágenes fotográficas producidas tanto por Bruch como por Wehrli44.

\footnotetext{
${ }^{42}$ En la actualidad San Carlos de Bariloche.

43 Además de las tareas específicamente referida al trazado de los límites estas subcomisiones tenían asignados "trabajos geográficos y meteorológicos" donde "Cada Comisión llevará un registro para anotar: a) las temperaturas
} 


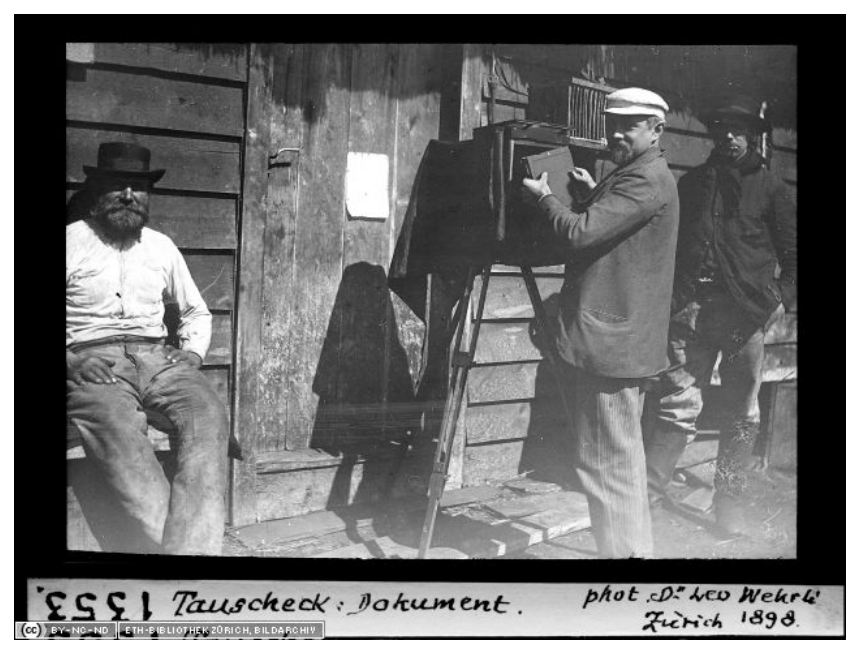

Figura 10. "Tauschek: Dokument." (L. Wehrli, 1898) (ETHZ).

En esta imagen vemos a Bruch preparándose para tomar una fotografía frente a la casa de José Tauschek.

En ocasión de estar de paso por el Cañadón Ahlefeldt, Wehrli se detuvo a tomar una fotografía a un grupo de gansos con los que se topó (Figura 11), acción que a su vez fue observada y fotografiada por Carlos Bruch (Figura 12). Resulta muy difícil poder reconstruir una secuencia fotográfica de características tan interesantes como esta, sobre todo a través de imágenes pertenecientes a distintos archivos, por lo que nos detendremos a analizarla brevemente.

Tal como se señala comúnmente, para el siglo XIX la fotografía era considerada como un registro o copia fiel de la realidad. Esta "tesis de la mimesis" como la defina Dubois $(1986)^{45}$, llevaba a entender a la fotografía como una "ventana al mundo", un procedimiento "transparente", en tanto reflejaba la realidad "objetivamente" y sin intervención alguna de la mano del hombre. La aparente transparencia del fenómeno fotográfico se ve reforzada por el hecho de que a pesar de que es sabido que las imágenes fotográficas son producidas por alguien que estuvo allí y observó lo que el espectador observa en la imagen, lo que se muestra representado en la fotografía no

máximas y mínimas de cada campamento, b) la presión atmosférica por barómetros de mercurio y aneroide, en cada punto culminante, paso, etc., c) la temperatura de ebullición del agua en los mismos puntos., d) las indicaciones geológicas, botánicas ú otras observaciones que ocurran y que fuese posible recoger, sin perjuicio de los trabajos de demarcación." (República Argentina 1902: 1088)

${ }^{44}$ Gran cantidad de imágenes tomadas por este geólogo se encuentran depositadas en el archivo de imágenes de la biblioteca del Eidgenössische Technische Hoschschule, Zürich, Suiza (de aquí en adelante ETHZ), mientras algunas de las imágenes que tomó Bruch en este viaje se encuentran en el Museo de La Plata.

${ }^{45}$ Para Dubois este discurso atribuye el efecto de realidad ligado a la imagen fotográfica a la semejanza existente entre la foto y su referente, donde la fotografía es percibida por el ojo natural como un "análogo" objetivo de lo real. (Dubois 1986: 20) 
ofrecería la posibilidad de constatar visualmente la presencia del fotógrafo. Todo lo que contribuiría a naturalizar la imagen y observarla con ojos ingenuos, asimilando lo real a su representación.

Figura 11. "Gänse, Cañadón Ahlefeldt"

(L. Wehrli, 1898) (ETHZ)
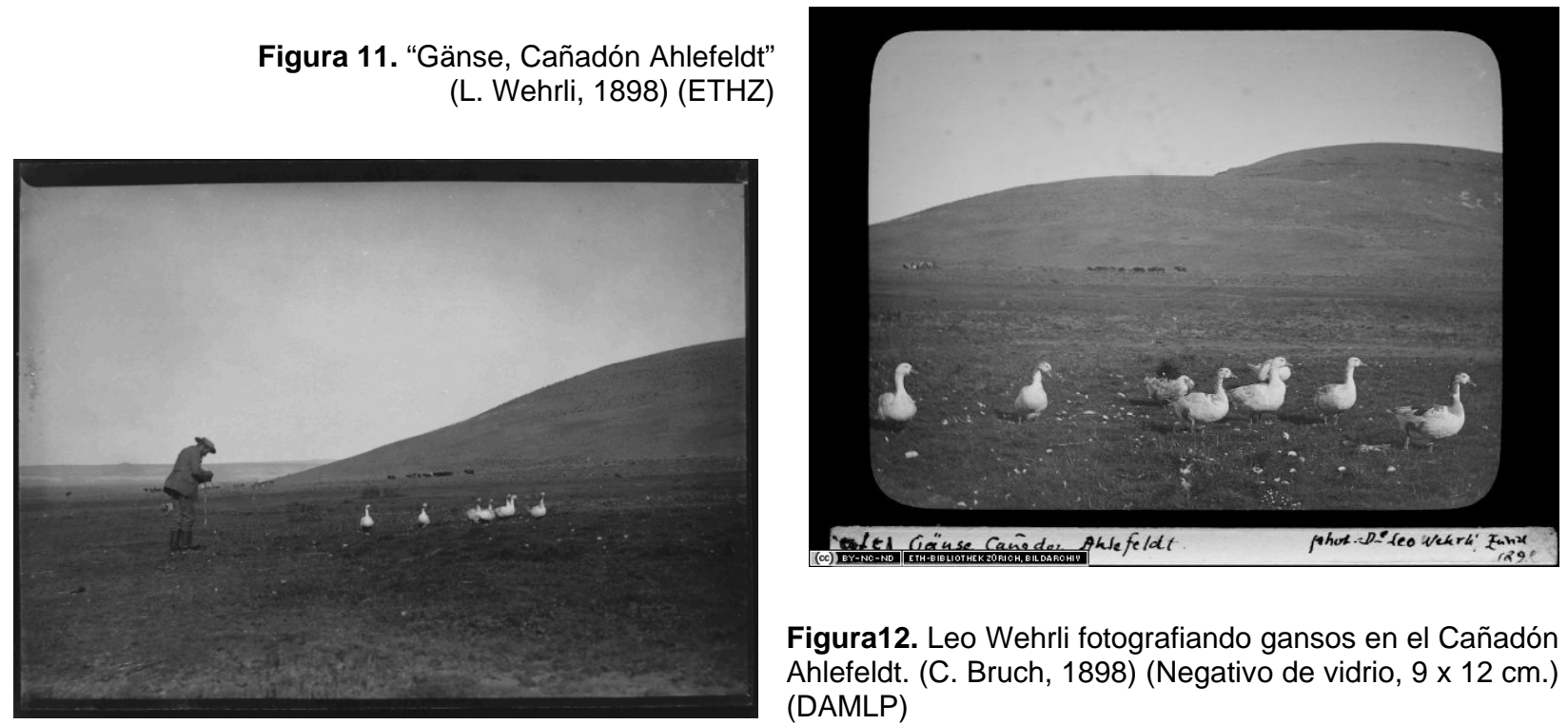

Figura12. Leo Wehrli fotografiando gansos en el Cañadón Ahlefeldt. (C. Bruch, 1898) (Negativo de vidrio, 9 × $12 \mathrm{~cm}$.) (DAMLP)

Sin embargo, si observamos la Figura 12 podemos notar que por intermedio de ella Bruch desplaza de su lugar habitual al espectador, interrumpiendo lo que Solomon Godeau (1992) Ilama "congruencia estructural del punto de vista", donde tanto el ojo del fotógrafo como el de la cámara y el del espectador observan desde un mismo punto de vista, que es el punto de vista elegido por el mismo fotógrafo. Haciendo explícita la presencia del fotógrafo y su cámara se opera una ruptura con este punto de vista congruente, lo que otorga una complejidad inusual a esta fotografía. En este sentido la Figura 11, que podría considerarse una imagen irrelevante o poco significativa y con un cierto aire de naturalidad e ingenuidad, entra en un fuerte contraste con aquella imagen, quedando en cierta forma "desnaturalizada" por la imagen que la antecede, y que deja en evidencia la presencia del fotógrafo en el instante preciso en que está construyendo su punto de vista. 
Por otra parte Bruch realizó durante este trayecto algunos hallazgos arqueológicos que luego dio a publicidad en la Revista del Museo de La Plata (Bruch 1902), una serie de "esculturas" en una cueva próxima a Junín de Los Andes y una "piedra pintada" cerca del arroyo Vaca Mala, de cuya existencia Bruch tuvo conocimiento por el comentario de su guía en ese viaje (Bruch 1902: 173). Al pie de esa piedra Bruch halló restos de alfarería que relacionó con "los artistas de las pinturas" (Bruch 1902: 175) aunque no pudo atribuir esas pinturas a ningún pueblo indígena en particular a pesar de haber consultado a los "araucanos que viven actualmente en aquellas regiones" quienes no le pudieron dar información sobre ello. (Bruch 1902:175)

Una vez regresado de este viaje, en abril de 1898, Bruch permanecería relativamente estable en La Plata, y aunque realizó junto a Robert Lehmann-Nitsche dos trabajos de fotografía antropológica en 1898 y en 1899 (Lehmann-Nitsche) ambos tuvieron lugar en Buenos Aires, por lo que fueron realizados en el transcurso de una jornada de trabajo. Recién en marzo de 1902 Bruch volvería a recorrer territorio patagónico acompañando a Francisco Moreno quien desde principios de ese año se encontraba en Londres, haciendo los preparativos para la inminente visita de la Comisión arbitral inglesa ${ }^{46}$ comandada por Thomas Holdich $(1843-1929)^{47}$ que vendría a observar los territorios en litigio con Chile para elaborar el dictamen final sobre esa disputa.

\footnotetext{
${ }^{46}$ Esa comisión estaba conformada por 5 miembros, el Coronel Holdich al mando, Capitán C. L. Robertson Comisionado asistente; el Capitán B. Dickson, Comisionado asistente; Capitán W. Thompson, Comisionado asistente; Teniente H. A. Holdich, Secretario (Holdich 1904: 63)

47 El Coronel sir Thomas Hungerford Holdich, era en ese momento presidente de la Royal Geographical Society y reputado experto en cuestiones limítrofes.
} 


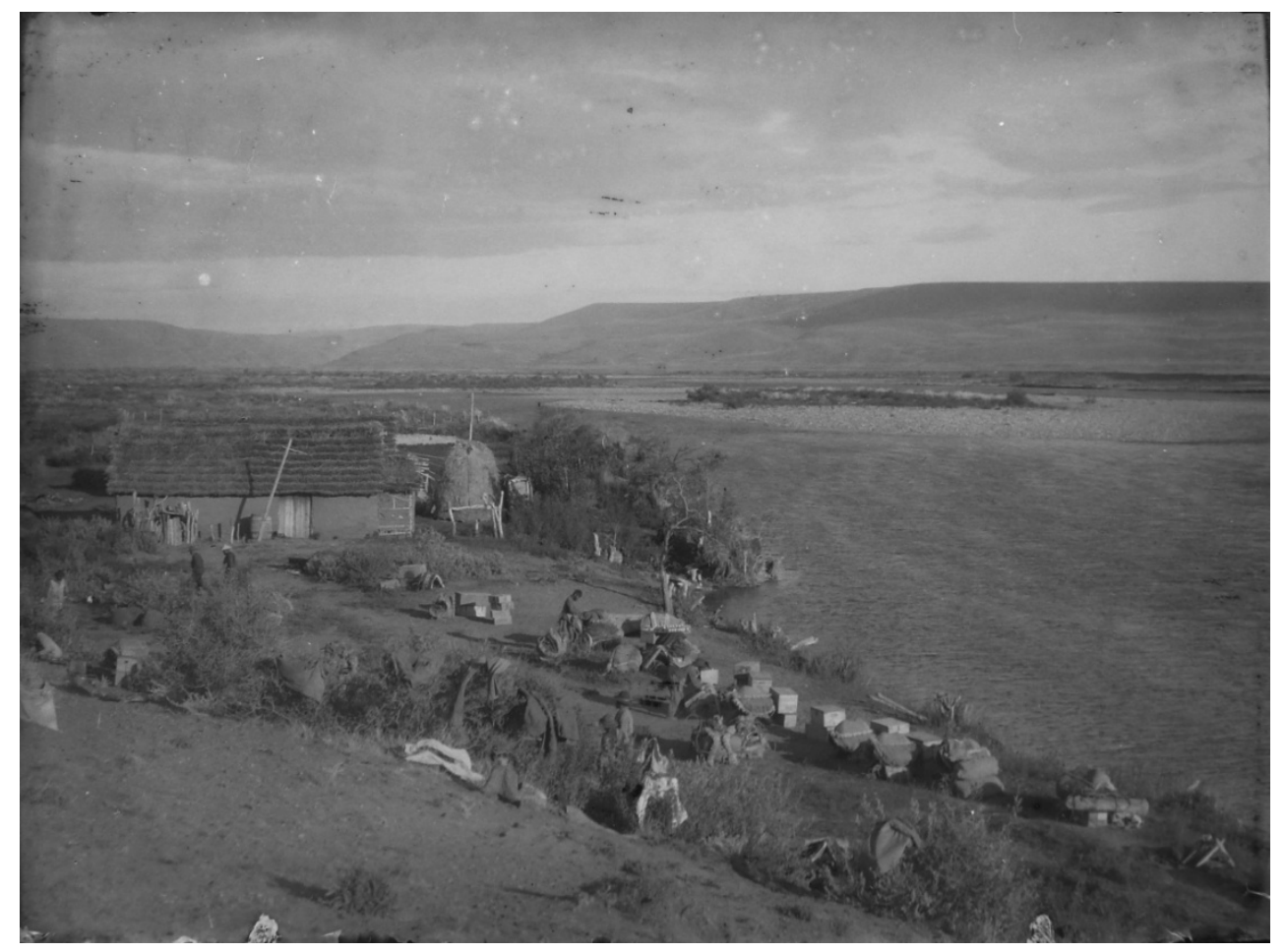

Figura 13. "N²5. 26. III. 902" (C. Bruch, Negativo de vidrio, $9 \times 12 \mathrm{~cm}$.) (DAMLP) "El 26 de marzo cambiamos de rumbo; no íbamos por el camino viejo hasta el Traful, sinó directamente á la orilla del Limay. Después del mediodía llegamos a la gran bajada y nos dirigimos hacia el Paso de Miranda, empleando el resto de la tarde en transportar nuestro equipaje á la otra orilla del río."(Bruch, 1904b: 71)

El 15 de enero de 1902 Moreno le comunicaba mediante una carta a Florencio Domínguez, Ministro argentino en esa capital, el recorrido que haría Holdich por la zona en disputa, a la vez que le solicitaba se dispusieran los recursos necesarios para esa expedición. Entre otras cosas solicitaba que "se prevenga al S. D. Carlos Bruch fotógrafo de la Comisión de Límites que deberá partir conmigo pues Sir Thomas necesita de sus servicios" ${ }^{\prime 4}$. De esta forma a fines de marzo de 1902 Bruch partió en viaje por la Cordillera de los Andes, desde el Río Limay hasta Comodoro Rivadavia. En ese viaje, en el que también participaron el geólogo y paleóntólogo Santiago Roth (1850-1924) y el ingeniero Gunardo Lange (1855-1915) por el Museo de La Plata, Bruch estuvo a cargo de la parte fotográfica, y el mismo Holdich lo calificó como un “invalorable artista fotográfico" (Holdich 1904: 391)

\footnotetext{
${ }^{48}$ Carta de Francisco Moreno al Ministro Florencio Domínguez, Londres 15 de enero de 1902. (AHCA Caja No AH0001, Exp. 4, copia mecanografiada)
} 


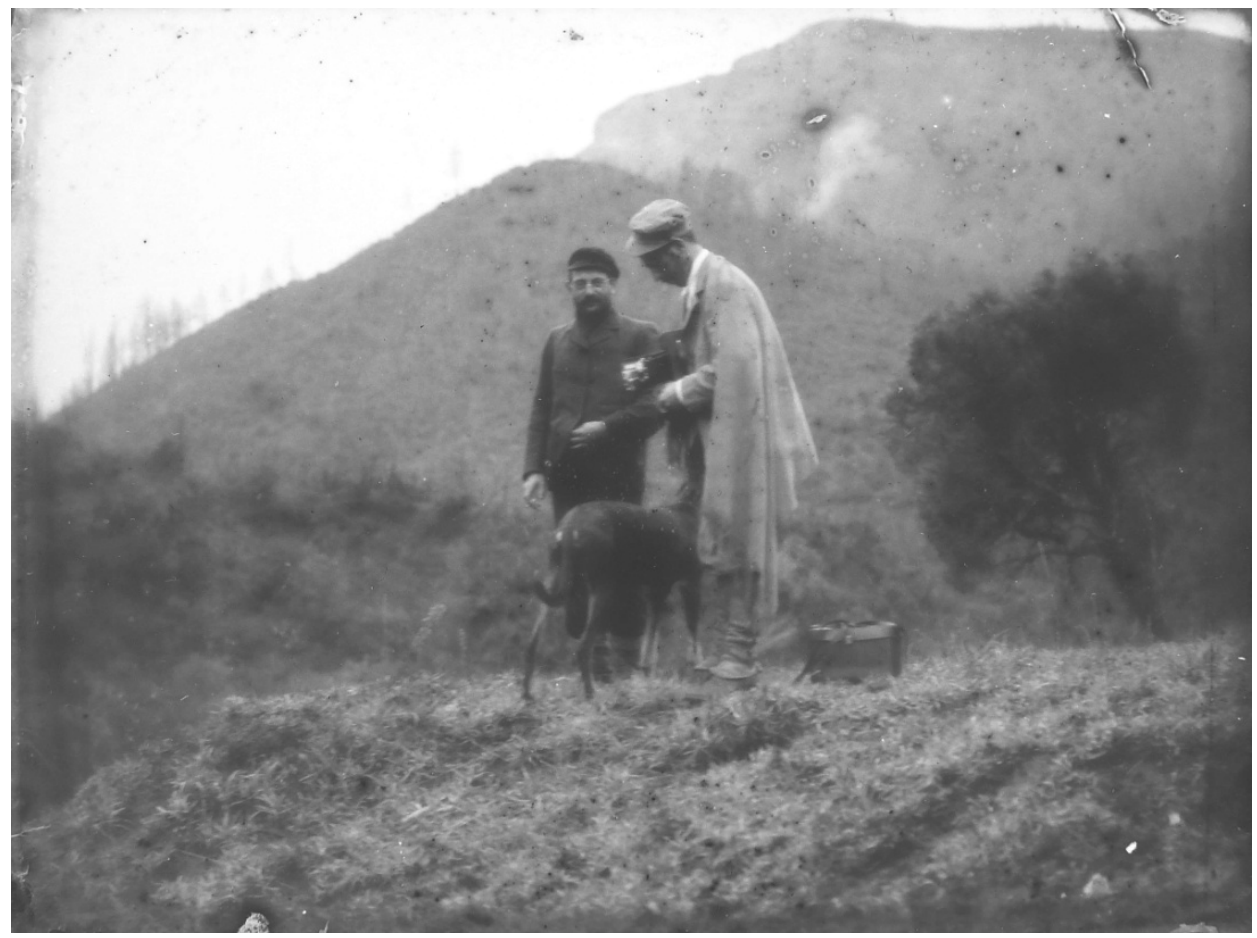

Figura 14. " $\mathrm{N}^{\circ} 76$ D. 19. IV. 902" Dos miembros de la Comisión Arbitral Inglesa tomando una fotografía. (C. Bruch, 1902) (Negativo de vidrio, $9 \times 12 \mathrm{~cm}$.) (DAMLP)

Bruch acompañó a esta comisión durante aproximadamente 3 meses hasta mediados de junio de 1902, recorriendo los territorios que iban desde la confluencia de los ríos Neuquén y Limay hasta la altura del río Senguer, al suroeste de Chubut, por el cual siguieron a la costa atlántica para abordar en Comodoro Rivadavia un barco que los traería de vuelta a Buenos Aires. Aunque Bruch no consideraba este viaje de particular interés para é ${ }^{49}$, se encargó de llevar un detallado registro visual del mismo. Prueba de ello es la serie fotográfica compuesta por más de 120 imágenes, número que podemos inferir por las inscripciones que el propio realizó en los negativos, algunos de los cuales se encuentran conservados en tanto en el Departamento de Arqueología como en el Archivo Histórico y Fotográfico del Museo de La Plata ${ }^{50}$.

\footnotetext{
${ }^{49}$ Carta de Carlos Bruch a Robert Lehmann-Nitsche, La Plata 1 de marzo de 1902 (Legado Robert Lehmann-Nitsce, IAl, Berlin, Alemania, N-0070 b-60)

${ }^{50}$ Estas fotografías están aún a la espera de un trabajo de limpieza, conservación, inventario y reprografía.
} 


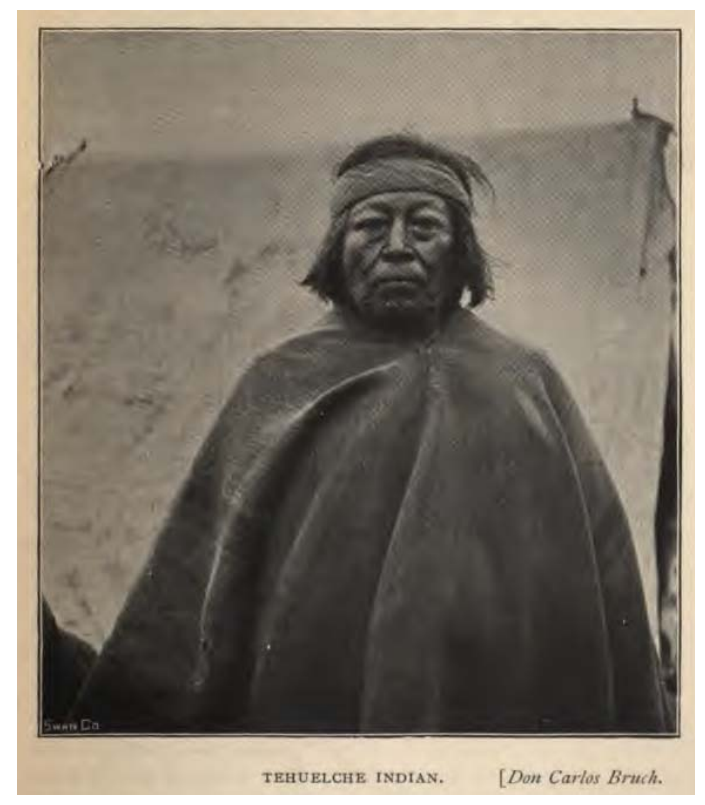

Figura 15. "Tehuelche Indian. [Don Carlos Bruch." (Holdich 1904: 387)

En el libro que publicó en 1904 ("The countries of the King's award") Holdich da una detallada cuenta de su paso por tierras patagónicas, al tiempo que incluye varias fotografías tomadas por Carlos Bruch en ese trayecto, de las cuales aquí reproducimos solamente dos donde aparecen retratados indígenas patagónicos (Figuras 15 y 16). Una de ellas, la Figura 16, retrata a un grupo de tehuelches que visitó el campamento de la comisión el día 31 de mayo de 1902, y que Holdich describía de la siguiente manera:

"hombres bien constituidos (pero no gigantes) con una expresión franca y agradable sobre sus amplios y tranquilos rostros, (...) para mis ojos no científicos ellos podrían fácilmente ser hermanos o primos de cualquiera de los otros indios sudamericanos que conocí. (...) Como todos los indios, su gran temor era ser echados de sus territorios de caza. Ellos querían una "reserva"." (Holdich 1904: 392, mi traducción) 
Figura 16. "Patagonian Indians. [Don Carlos Bruch."

A la mañana siguiente, el 1 de junio de 1902, luego de una intensa nevada y antes de que la comisión levantase campamento para seguir su marcha, Bruch "aseguró su registro fotográfico de nuestros indios amigos". (Holdich 1904: 392) (Figura 16)

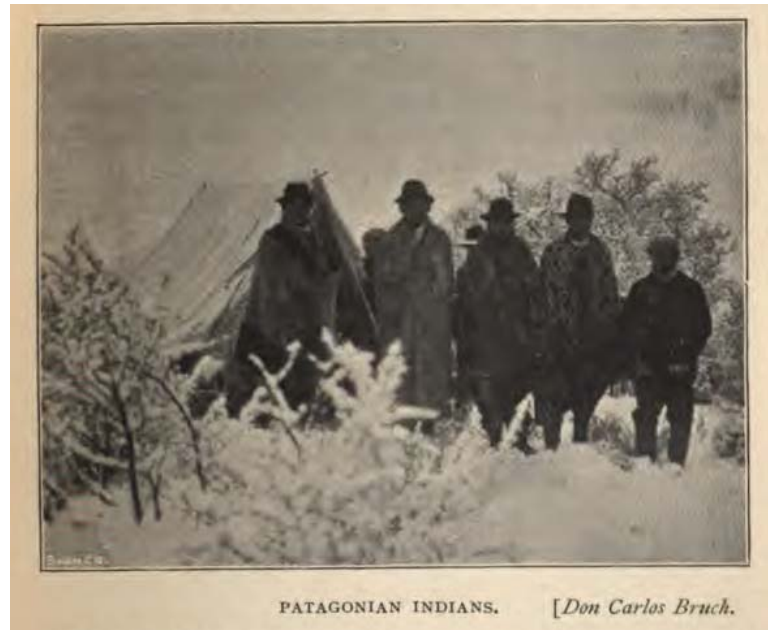

Al año siguiente de este viaje, entre setiembre y octubre de 1903, Bruch volvería a acompañar a Moreno en otra excursión junto a la "Comisión Científica Alemana", como la nombraron los medios periodísticos porteños ${ }^{51}$, conformada por los geólogos alemanes Gustav Steinmann (1856-1929), el barón Alexander von Bistram (1859$1905)^{52}$ y Henry William Hoek (1875-1951) por el Noroeste argentino y sur de Bolivia y que tenía por objetivo estudiar la geología de esas regiones. A mediados de setiembre la expedición hizo un recorrido de una semana por el oeste de Jujuy en la zona de las sierras de Zapla y el río Garrapatal. El 23 de ese mes emprendieron camino a Bolivia por la Quebrada de Humahuaca, pasando por Humahuaca, Abra de Tres Cruces y Cochinoca hacia Rinconada (Hoek y Steinmann 1906: 3). El 2 de octubre salieron de Rinconada atravesando la pampa de Pozuelos, y al llegar a la Laguna de Pozuelos, los hombres del Museo de La Plata regresaron a Buenos Aires mientras los alemanes continuaban el trayecto a Bolivia.

En su recorrido por la puna jujeña, la expedición pasó por la Mina Danesa donde Bruch tomó una fotografía de sus compañeros de viajes (Figura 17). En esta imagen se puede ver, de derecha a izquierda, en primer lugar a Francisco Moreno, acompañado por los

\footnotetext{
${ }^{51}$ Caras y Caretas $N^{\circ} 258,12$ de setiembre de 1903.

52 Poco después de regresar a Alemania, en julio de 1905, y encontrándose en Waddax, su pueblo natal, el Barón von Bistram murió baleado en ocasión de una revuelta. (Hoek y Steinmann 1906: 1).
} 
tres miembros de la nombrada (Steinmann, Bistram y Hoek). Esta fotografía, que se conserva en el Departamento de Arqueología del Museo de La Plata, fue publicada del 12 de diciembre 1903 de la revista Caras y Caretas formando parte de un almanaque que mostraba personajes ilustres, ciudades, edificios, paisajes e industrias de las provincias de Tucumán, Salta y Jujuy. Bruch y Moreno regresaron de este viaje Es muy probable que otra de las imágenes utilizadas en el almanaque de Jujuy haya sido tomada por Carlos Bruch y, tal vez, cedidas o vendidas a esa revista que declaraba que esas imágenes eran de su propiedad (Figura 18). La imagen a la que nos referimos fue ubicada abajo y a la izquierda de la fotografía de la Mina Danesa, y en su leyenda puede leerse "Chorotos que trabajan en el Ingenio Esperanza". Nuestra presunción se basa en que durante este mismo viaje Bruch estuvo de paso por ese ingenio donde quedó sorprendió por la cantidad de indígenas chaqueños que halló en él, por lo que les tomó algunas fotografías (Cfr. Figura 19).

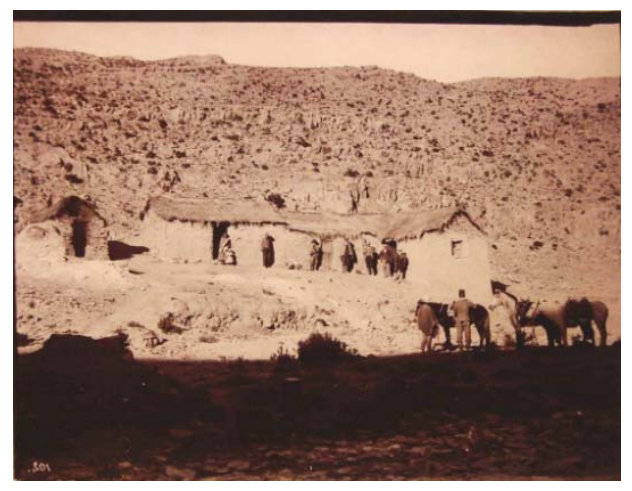

Figura 17. Francisco Moreno y la Comisión Científica Alemana en viaje por Jujuy.

(C. Bruch, 1903 copia en papel 9X12 cm.) (DAMLP)
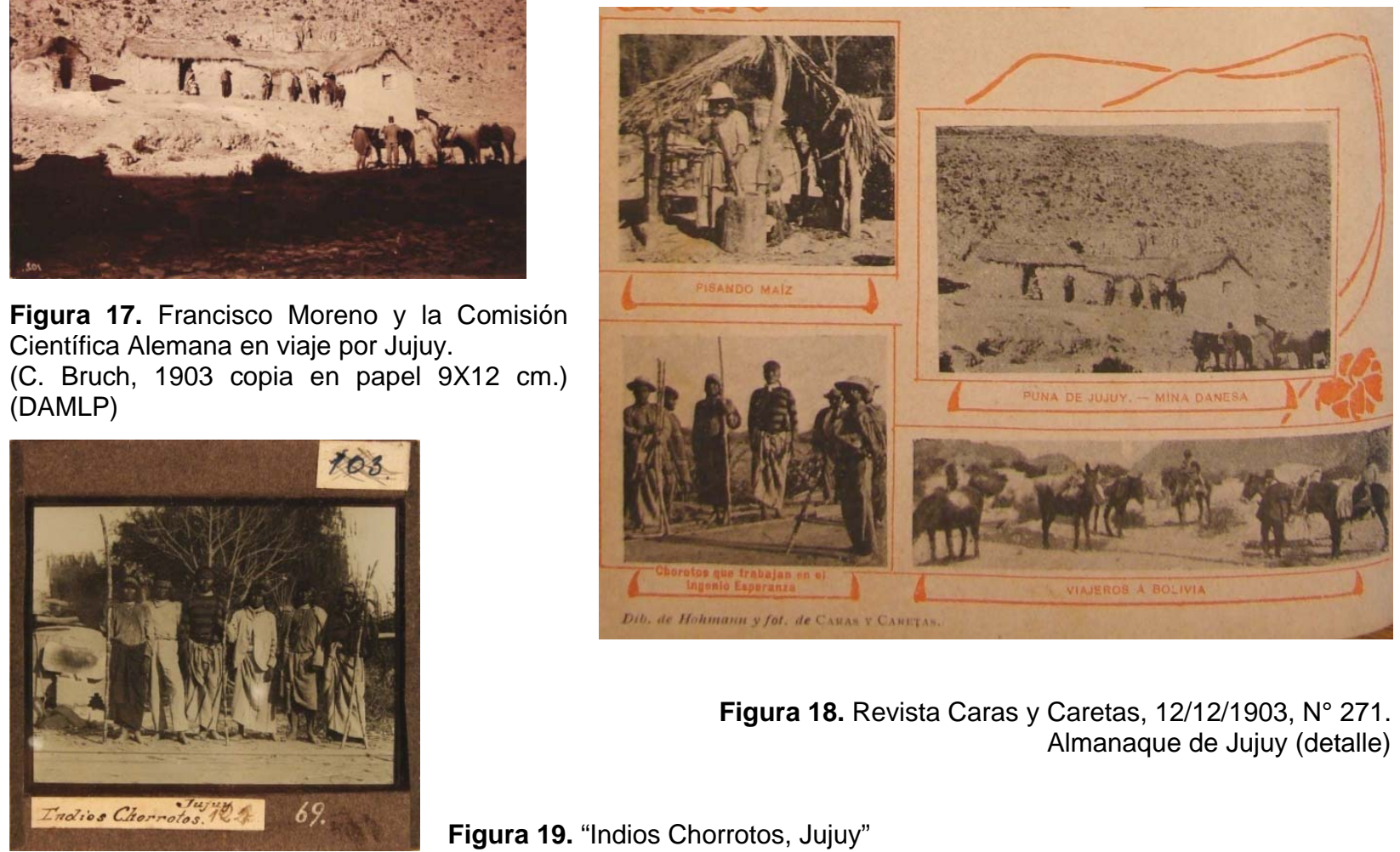

Figura 18. Revista Caras y Caretas, 12/12/1903, Nº 271. Almanaque de Jujuy (detalle)

Figura 19. "Indios Chorrotos, Jujuy"

(C. Bruch, 1903, Diapositiva de vidrio 8 X 8 cm.) (DAMLP) 
En este viaje además, Bruch tomó una buena cantidad de "vistas de gentes, paisajes y edificios", siendo notables las fotografías que tomó de las antiguas iglesias de la Puna y la Quebrada Jujeña, como las de Purmamarca y Cochinoca, la cual aquí reproducimos (Figura 20).

Figura 20. Iglesia de Cochinoca, Salta (C. Bruch, 1903, Negativo de vidrio $9 \mathrm{X}$ $12 \mathrm{~cm}$.) (DAMLP).

A la derecha de la imagen puede apreciarse la antigua torre de adobe de la cual actualmente solo se conserva su base.

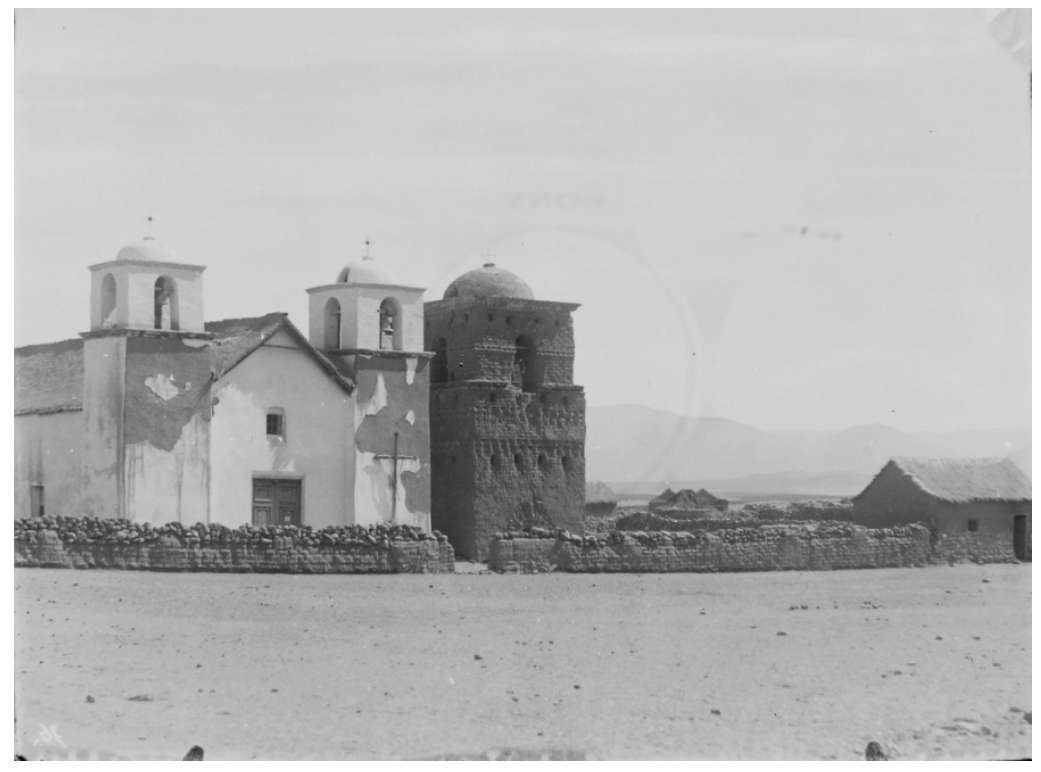

Hacia fines de 1904 encontramos a Bruch acompañando nuevamente al Dr. Moreno en un recorrido por los territorios de Misiones y Paraguay, y que fuera calificado por el propio Bruch como su "desafortunado viaje a Paraguay y Misiones"53, a causa de una serie de contratiempos que se le fueron presentando. En primer lugar tuvo al parecer ciertas diferencias con Moreno que lo llevaron a separarse de él y emprender su propio trayecto ${ }^{54}$, durante el cual visitó las Cataratas del Iguazú las que no obstante el mal tiempo que había soportado durante el viaje se encontraban con muy poco agua ${ }^{55}$. Posteriormente perdió sus resultados y placas fotográficas debido a que la lancha que

\footnotetext{
${ }^{53}$ En el alemán original: "meiner Paraguay-Misiones-Unglückstour" (Carta de Bruch a Lehmann-Nitsche del 3 y 10 de octubre de 1904. (Legado Roberto Lehmann-Nitsche IAI, Berlin, N-0070, b-60)

${ }^{54}$ Según Bruch, Moreno estaba "simplemente insoportable por lo que decidí separarme ya en la segunda semana en Asunción". (Carta de Bruch a Lehmann-Nitsche del 3 y 10 de octubre 1904. (Legado Roberto Lehmann-Nitsche IAI, Berlin, N-0070, b-60, mi traducción)

${ }^{55}$ Carta de Bruch a Lehmann-Nitsche del 3 y 10 de octubre 1904. (Legado Roberto Lehmann-Nitsche IAI, Berlin, N0070 b-60)
} 
lo transportaba, hecha de la corteza ahuecada de un árbol, se dio vuelta al atravesar un sector de rápidos ${ }^{56}$. No pudiendo recuperar el trabajo perdido debido a una seguidilla de días de mal tiempo que no le permitieron salir al campo ${ }^{57}$. A pesar de ello Bruch pudo recuperar algo del tiempo y esfuerzo perdido, al menos en cuanto a lo que se refiere a las fotografías ya que en el listado que ofrece al museo en 1906 incluyó "50 positivos viaje a Asunción, Villa Rica, Posadas, Alto Paraná, Iguazú y Alto Iguazú. .58

Figura 21. Vista de las Cataratas del Iguazú vidrio, $8 \times 8 \mathrm{~cm}$.)

(DAMLP)

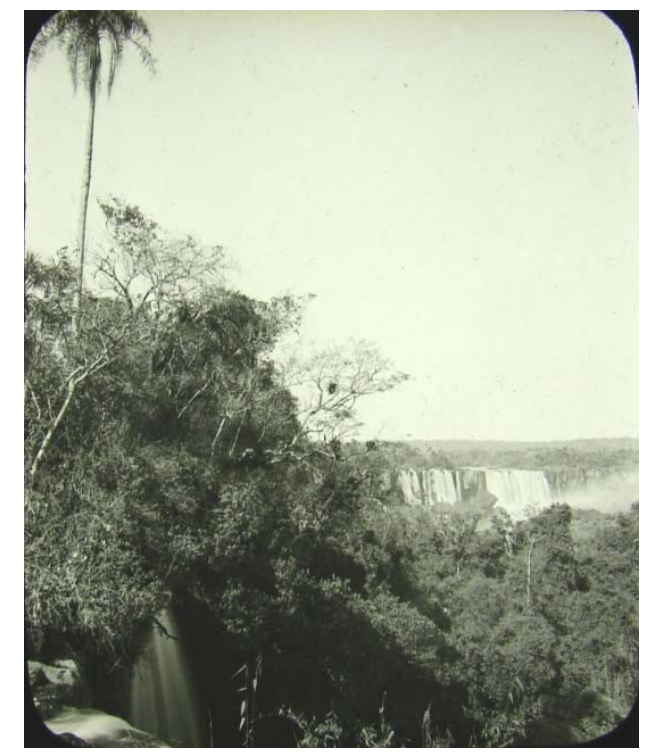

Luego de este viaje Bruch regresó al noroeste argentino en 1906; esta vez fue a San Pedro de Jujuy junto con Robert Lehmann-Nitsche, en busca de aquellos indígenas chaqueños que había visto por primera vez tres años antes, trabajando en la zafra en el Ingenio La Esperanza. Esta vez fue mejor preparado llevando una cámara fotográfica de gran tamaño $(18 \times 24 \mathrm{~cm}$.) propiedad del Museo y su pequeña cámara de mano de formato 9X12 cm., con las que tomó más de 200 fotografías. Hacia el final de este capítulo nos dedicaremos a los trabajos fotográficos en los que Carlos Bruch colaboró con el antropólogo Robert Lehmann-Nitsche.

\footnotetext{
${ }^{56}$ Carta de Bruch a Lehmann-Nitsche del 3 y 10 de octubre1904. Legado Roberto Lehmann-Nitsche IAI, Berlin. Por otra parte para esa misma época su mujer perdió un embarazo de un hijo varón. (Carta de Bruch a Lehmann-Nitsche del 29/11/1904. Legado Roberto Lehmann-Nitsche IAI, Berlin, b-60)

57 Carta de Carlos Bruch a Roberto Lehmann-Nitsche del 3 y 10 de octubre de 1904. (Legado Roberto LehmannNitsche IAI, Berlin, N-0070 b-60)

${ }^{58}$ Carta de Carlos Bruch a Samuel Lafone Quevedo, La Plata, 10 de diciembre de 1910 (AHFMLP)
} 


\section{El viaje al Ingenio La Esperanza}

A mediados de julio de 1906, Robert Lehmann-Nitsche y Carlos Bruch emprendieron un viaje de estudios al Ingenio La Esperanza en el oeste de la provincia de Jujuy, luego de un breve paso por Córdoba donde Lehmann-Nitsche visitó al científico alemán Adolfo Doering. No era esta la primera vez que Carlos Bruch visitaba ese ingenio, donde ya había estado en 1903 durante el viaje que realizó acompañando a Moreno y la comisión científica alemana. Fue justamente en la primera parte de ese viaje, mientras recorrían el oeste de Jujuy cuando conoció, casi de casualidad, el Ingenio La Esperanza. Bruch quedó impresionado por lo que pudo observar allí, por lo que decidió escribirle inmediatamente a Lehmann-Nitsche:

"Pasamos tres días en la selva totalmente atormentados por las garrapatas y los piques, por lo que nos fue imposible dormir durante tres noches. A la vuelta pasamos por San Pedro. Debido a que en el ingenio azucarero observé trabajar a muchos indígenas, fui hacia allí el domingo muy temprano. Logré tomar tipos de Chorrotos [SIC], Matacos y Chiriguanos, desafortunadamente sólo con la pequeña cámara de mano. Estaba completamente encantado y nunca pensé que uno puede encontrar aquí un material tan magnífico con tal facilidad. Si Usted entonces tuviera ganas en su próximo viaje de que emprendamos juntos esta excursión a Esperanza y Ledesma le puedo garantizar un trabajo monumental." ${ }^{59}$

De este modo, casi tres años después de esta carta, Bruch volvió a ese ingenio acompañando a Robert Lehmann-Nitsche para llevar adelante el trabajo de antropología física y fotografía antropológica más importante que llevara a cabo desde el Museo de La Plata por iniciativa de un coleccionista de insectos con excelente ojo de fotógrafo. Si bien no referiremos más detenidamente a los estudios que se realizaron

${ }^{59}$ Carta de Carlos Bruch a Robert Lehmann-Nitsche, San Pedro, Jujuy 22 de setiembre de 1903. (Legado Robert Lehmann-Nitsche, IAI, Berlin, N-0070, b-60) 
en este viaje, aquí nos gustaría marcar algunas cuestiones relacionadas con la fotografía de Carlos Bruch.

La mayor parte de las aplicaciones de la fotografía a los estudios de antropología hechas por Lehmann-Nitsche fueron emprendidas con la colaboración de Carlos Bruch $^{60}$. Ellas fueron las realizadas a los indígenas fueguinos que habían sido llevados a la Exposición Nacional de Buenos Aires en octubre de 1898 por el entonces gobernador del Territorio Nacional de Tierra del Fuego, Pedro Godoy (LehmannNitsche 1916). Al año siguiente (1899) y aprovechando la presencia en Buenos Aires de un contingente de indígenas Takshik que el empresario teatral José Podestá intentaba llevar para su exhibición en la Exposición Internacional de Paris (1900), Lehmann-Nitsche concurrió junto a Bruch adonde ese grupo se hallaba alojado para tomarles medidas y fotografías antropométricas.

Las fotografías que Bruch que tomó como colaborador de Lehmann-Nitsche respondían a un modo de fotografiar relativamente similar y estandarizado. Como veremos más en detalle en los capítulos siguientes, las fotografías antropológicas se tomaban buscando "neutralizar" el fondo de la imagen, ya sea mediante la utilización de un telón o retratando a las personas contra una superficie visualmente homogénea. Los retratados eran colocados delante de estos fondos en las ya clásicas posiciones de frente, perfil y espaldas para las fotos de cuerpo entero; y frente y perfil para las fotos de torso. Además, los sujetos debían retratarse desnudos para que las imágenes que se obtuvieran tuvieran valor antropológico ${ }^{61}$. Sin embargo, en 1906 comenzó a operarse un cambio en la visión fotográfica de Lehmann-Nitsche, donde no se respetó tan rigurosamente la postura de los sujetos tomándose fotos de 3/4 perfil, tampoco los fondos fueron tan controlados y en muchos casos no se intentó desvestir a los

\footnotetext{
${ }^{60}$ Como excepción podemos nombrar las fotografías que Lehamnn-Nitsche tomó durante su viaje a Tierra del Fuego en 1902, y las imágenes que obtuvo en el Chaco durante la década de 1920. En el caso de las imágenes de Tierra del fuego ellas no fueron tomadas de acuerdo a los principios de la fotografía antropológica que se aplicaron a los trabajos de 1899 y 1906. Lo mismo podemos decir en cuanto a las fotografías tomadas en Chaco cuando, por otra parte, Bruch ya se había jubilado, mudándose con su familia a Olivos, y aunque seguía vinculado al Museo y a la actividad científica se hallaba dedicado de lleno a la entomología.

${ }^{61}$ Esta clase de imágenes ya fue objeto de otras investigaciones -Giordano (2005), Martínez y Tamango (2006) y Martínez (2009)- y en esta tesis nos referimos a ellas en la Introducción y capítulos III y IV.
} 
indígenas fotografiados. A pesar de estas diferencias estas fotografías tenían en común que en todas ellas se procedió a una cierta preparación de la escena antes de ser tomadas, el arreglo del fondo, la postura de los sujetos, la medición de la luz, entre otros detalles.

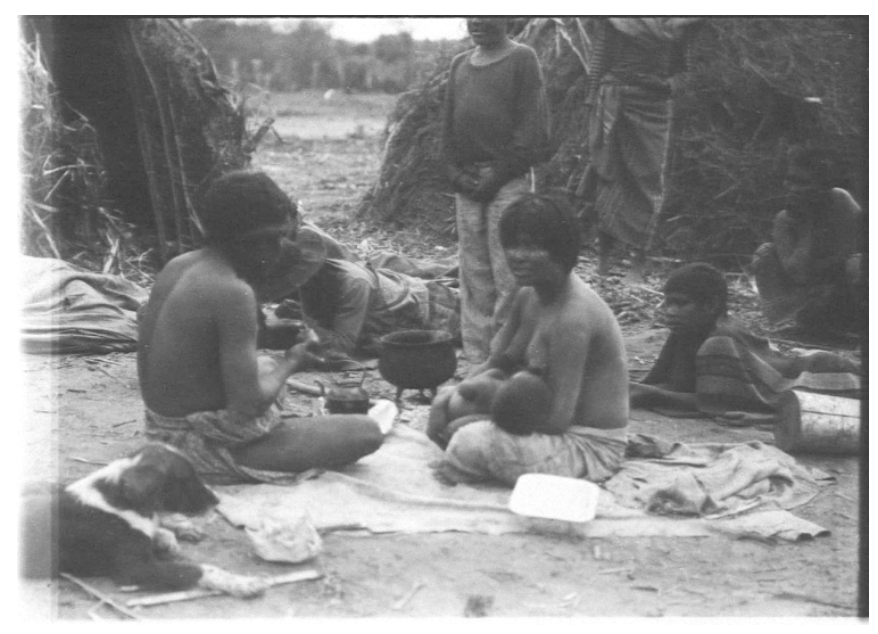

Figura 22. Grupo de indígenas chaqueños tomando mate junto a sus viviendas (huetes) en el Ingenio La Esperanza (C. Bruch 1903-1906?) (Legado Robert Lehmann-Nitsche, IAI, Berlin, N-0070, s47)

En contraposición a estas fotografías antropológicas, a las cuales nos dedicaremos más adelante, contamos además con una serie de fotografías "instantáneas" tomadas por Carlos Bruch en sus viajes de 1903 y $1906^{62}$ que no fueron publicadas en 1907 ni posteriormente, y que no superan las dos docenas. Estas imágenes, que permanecieron prácticamente ignoradas ${ }^{63}$, representan aspectos poco conocidos de este viaje y en ese sentido cobran relevancia para la investigación histórica, ya que nos plantean nuevos interrogantes sobre la relación establecida entre los investigadores del museo y los trabajadores indígenas y también con respecto a la cotidianeidad de los indígenas en el ingenio (Figura 22).

\footnotetext{
62 No nos fue posible determinar por completo cuales de estas fotografías pertenecen a uno y otro viaje. En algunos casos la aparición de Lehmann-Nitsche o de algún individuo que también fue fotografiado utilizando la cámara de gran formato nos permite fechar la fotografía con precisión pero esto no es posible para todos los casos.

63 Recientemente dos de estas imágenes fueron incluidas, a modo ilustrativo, en publicaciones científicas, una de ellas en Hoffman y Wolff (2008) y la otra en Farro (2009).
} 
Figura 23. Dos mujeres en el Ingenio La Esperanza. (C. Bruch, 1906, Ingenio La Esperanza, Jujuy) (Legado Robert Lehmann-Nitsche, IAI, Berlin, N-0070, s47).

Podemos observar en esta inusual e interesante fotografía como la mujer más joven toma de la mano al tiempo que apoya su pie izquierdo sobre el pie derecho de su compañera.

Como vimos en la cita transcripta más arriba, cuando Bruch estuvo de paso por el ingenio en 1903 sólo llevaba consigo su pequeña cámara de mano de formato 9 X 12 cm. Con esa cámara, como el mismo relata, obtuvo algunas fotografías de los indígenas en el ingenio, una de las cuales, según sostenemos, fue publicada en la revista Caras y Caretas de diciembre de 1903 (Ver Figuras 17, 18 y 19). En su segunda visita al Ingenio, Bruch fue mejor preparado llevando consigo al menos dos cámaras fotográficas. Con una de ellas, perteneciente al museo, y de gran formato $(18 \times 24 \mathrm{~cm}$.), realizó las fotografías antropológicas. Junto con esta cámara Bruch llevó cerca de doscientas placas fotográficas de ese formato, lo que equivale a entre 15 y 16 cajas de placas $^{64}$. La cámara más pequeña, de formato $9 \times 12 \mathrm{~cm}$., que era de su propiedad, fue utilizada para tomar varias “instantáneas” del Ingenio La Esperanza, alrededor de dos docenas de esas imágenes se conservan en el Museo de La Plata y el Instituto Iberoamericano de Berlin ${ }^{65}$. Aunque Bruch también tomó unas pocas fotos antropológicas con esta cámara, sobresalen entre ellas varias fotografías que muestran

\footnotetext{
${ }^{64}$ Cada caja de negativos de vidrio contenía una docena de placas.

${ }^{65}$ En el capítulo VI daremos un informe completo respecto a las fotografías tomadas en ocasión de este viaje.
} 
aspectos interesantes que pueden resultar pertinentes para generar nuevas preguntas tanto acerca de la relación de los antropólogos con los indígenas como de la cotidianeidad de los indígenas en el Ingenio (Figuras 22, 23, 24, 25 y 26).

Figura 24. Robert Lehmann-Nitsche encendiendo un cigarro a un indígena chaqueño en el Ingenio La Esperanza, Jujuy (C. Bruch, 1906. Negativo de vidrio $9 \times 12 \mathrm{~cm}$.) (DAMLP)
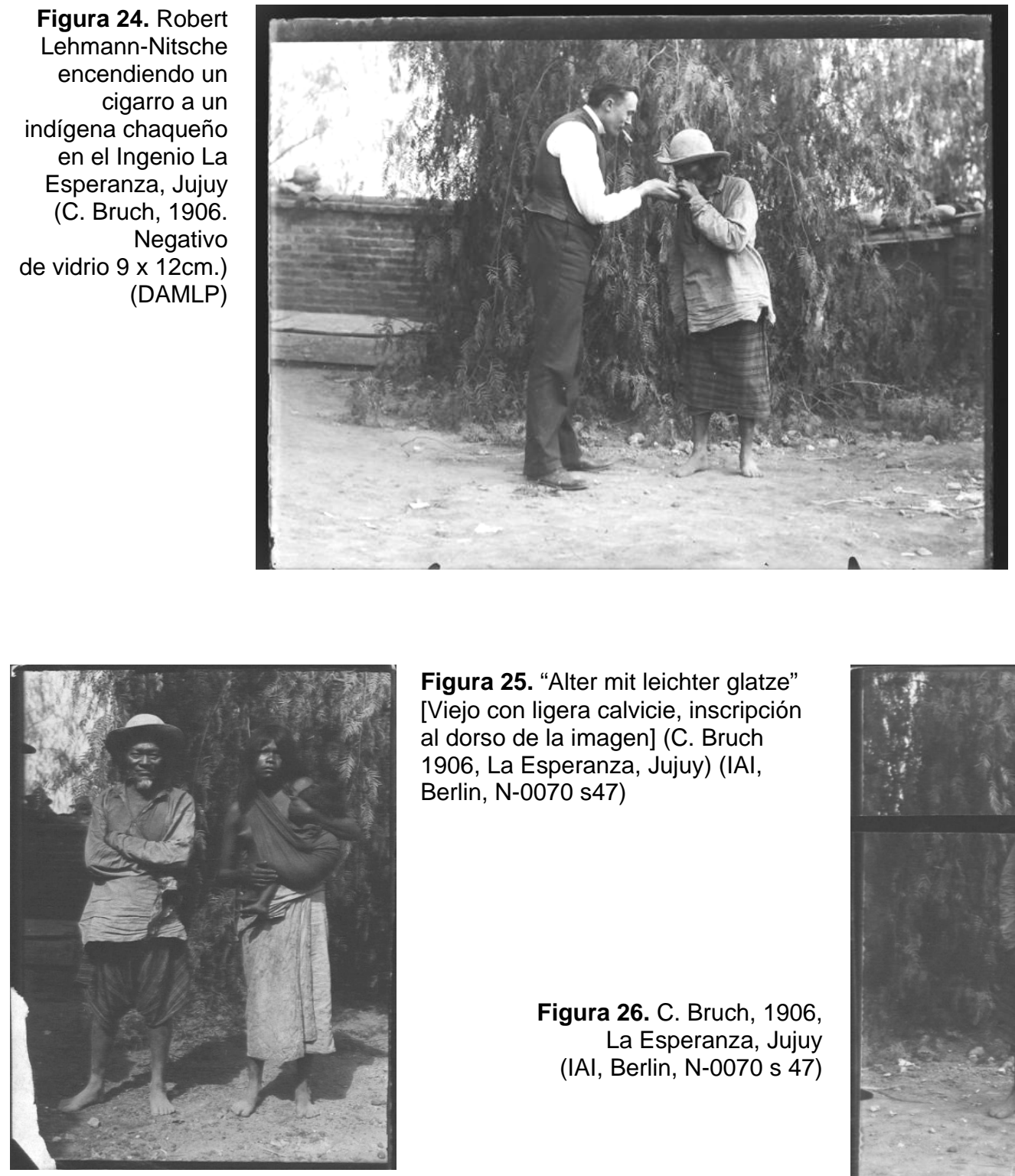

Figura 25. "Alter mit leichter glatze" [Viejo con ligera calvicie, inscripción al dorso de la imagen] (C. Bruch 1906, La Esperanza, Jujuy) (IAI, Berlin, N-0070 s47)

Figura 26. C. Bruch, 1906, La Esperanza, Jujuy (IAI, Berlin, N-0070 s 47)

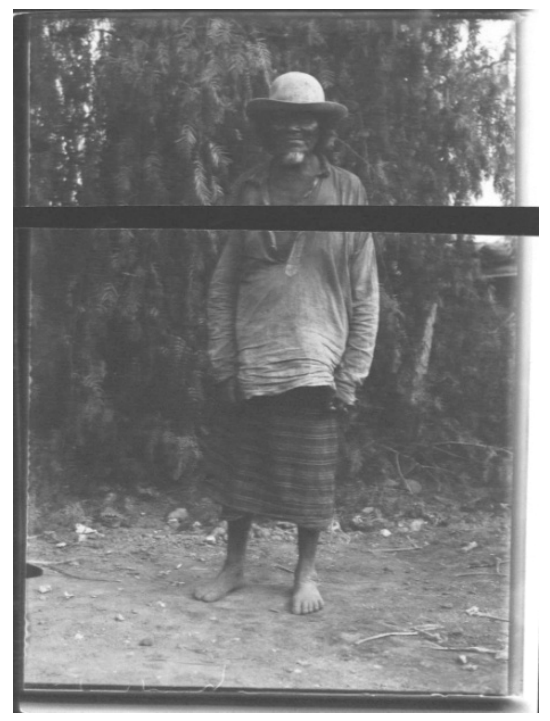


Esta interesante secuencia que logramos reconstruir está compuesta por tres fotografías que fueron tomadas con la cámara personal de Bruch $^{66}$. En todas ellas aparece el mismo hombre retratado junto a Lehmann-Nitsche en la Figura 24. La inscripción al dorso de la figura 26 coincide con la descripción de uno de los indígenas de La Esperanza que hace Lehmann-Nitsche (1907a: 89), cuya imagen, sin embargo, no fue incluida en ese atlas. Allí encontramos pudimos establecer que el retratado se llamaba "Chivo", tenía 85 años y provenía de Corrientes. Aunque en la publicación de 1907 no se incluyeron estas imágenes ni ninguna otra correspondiente a esta persona, la descripción en el dorso de la foto coincide con la descripción que se incluyó en esa publicación y que dice: "Cabello cortado, negro pardo con canas blanquizcas, áspero, ondulado. Pequeño grado de calvicie!" (Lehmann-Nitsche 1907a:89)

Por otra parte, gracias a esta secuencia es posible pensar que el momento en el cual Lehmann-Nitsche enciende el cigarro de esta persona pertenece a una pausa de la sesión fotográfica que estaba ejecutando Carlos Bruch quien, teniendo su cámara preparada, observó esa escena y decidió capturarla. Antes de ensayar alguna interpretación con respecto al carácter de la interacción que pudo haberse producido entre investigadores e indígenas, desde las fotografías, debemos tener en cuenta que esta acción capturada por la cámara representa solo un instante. En ese sentido, y de acuerdo a la perspectiva aquí propuesta, surge la necesidad de contar con otra clase de fuentes o testimonios que den mayor solidez a nuestras interpretaciones. Sin embargo, y a pesar de ello creemos que el valor de la fotografía en tanto "evidencia alternativa" al registro clásico (Fiore 2007:61) no reside en tanto las respuestas que podría brindar o en los indicios que llevaría inscriptos, sino más bien en los interrogantes que plantea.

\footnotetext{
${ }^{66}$ Esto pudo determinarse gracias a que el negativo de vidrio de $9 \times 12 \mathrm{~cm}$. que se conserva en el Museo de la Plata exhibe unas pequeñas impresiones negras en el lado inferior de la placa producidas seguramente por el soporte de la cámara que impidieron que esa zona sea expuesta a la luz por lo que al ser revelada tomó el color negro. Podemos observar restos de estas mismas impresiones en las figuras 23 y 24 , por lo cual suponemos que las tres fotografías fueron tomadas con la misma cámara. Además, la cámara de gran formato no producía estas "manchas" sobre las placas.
} 


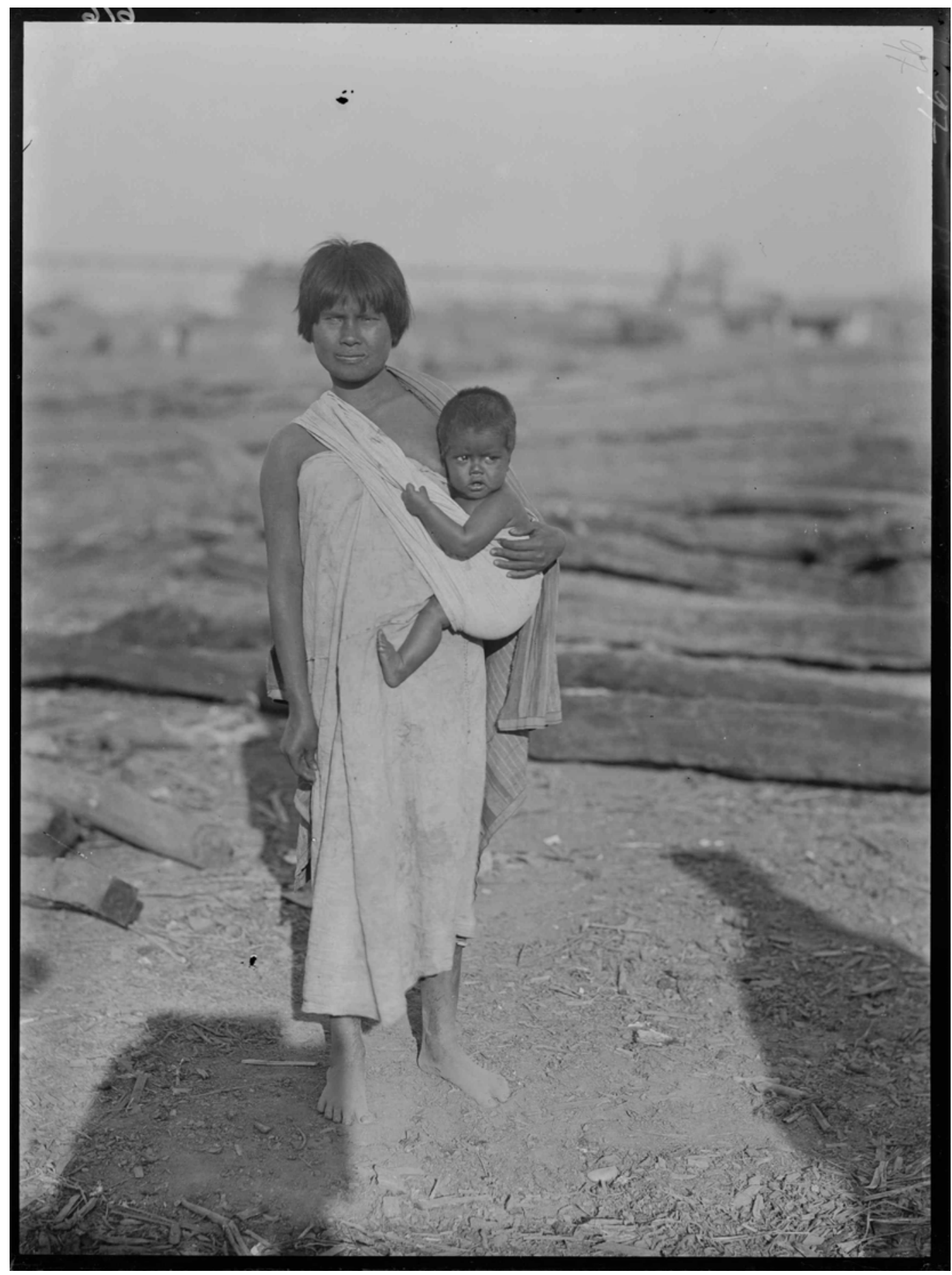

Figura 27. Mujer indígena del Chaco cargando un niño. (C. Bruch, Ingenio La Esperanza, Jujuy, 1906) (AHFMLP, AFO-002-001-006-0006) (Cfr. Figuras 11 y 12) 
Nos gustaría, finalmente hacer algunas consideraciones con respecto a la fotografía de Carlos Bruch. Según Jörg, desde el punto de vista fotográfico Bruch "trabajaba siempre "blando", buscando sacar riqueza en medias tintas, sin dar luces ni negros fuertes" (Jörg 1943: 90). Esta forma de evitar los contrastes fuertes puede percibirse en las fotos tomadas en Tucumán y Catamarca, a las que nos referimos más arriba. A pesar de que allí Bruch utiliza un fondo neutro como se acostumbraba en la fotografía antropológica este era un telón de tono grisáceo que matizaba las luces de la foto logrando de ese modo una mayor escala de grises, una reducción en el contraste y por consiguiente mayor riqueza de detalle.

Observemos ahora la última imagen incluida aquí, la Figura 27. Detrás de la mujer y su hijo pueden observarse rollos de madera e instalaciones fabriles. En el ángulo superior derecho se puede distinguir la numeración original que Bruch le asignó a esta imagen. El número 97 fue escrito por duplicado ambas veces del lado no emulsionado del vidrio con un punzón en un caso y con tinta en el otro ${ }^{67}$. Obsérvense además las sombras que denuncian la presencia de la cámara y posiblemente del mismo fotógrafo. Una vez más, como en el caso de las figuras 11 y 12, aunque por medio de otro procedimiento. Bruch ubica a la madre y su hijo entre la sombra de la cámara y la que tal vez sea su propia sombra. Al tiempo que la madre dirige su mirada a la cámara, el niño permanece observando al sujeto detrás de ella, dejando en evidencia la presencia del observador y la cámara.

A su vez esta misma imagen resulta un buen ejemplo de otro a rasgo a destacar en las fotografías de Bruch y que es su profundidad focal. Esta característica, también denominada profundidad de campo, corresponde a la zona que abarca desde el objeto más cercano al más lejano tomado por la cámara con igual nitidez (Russo 1998: 212). Los lentes utilizados por Bruch no proporcionaban originalmente tal profundidad, sino que él mismo se encargaba de modificar los diafragmas corriéndoles el tope para poder cerrarlos mucho más. Esta modificación por sí sola no proporcionaba la profundidad de

\footnotetext{
${ }^{67}$ La inscripción 6/6 fue realizada mucho más recientemente.
} 
campo deseada sino que el lente se cerraba al mayor grado compatible con la definición del objetivo utilizado. Este artilugio técnico de estricta óptica geométrica era usado por Bruch como recurso de rutina (Jörg 1943: 90). Por otra parte la posibilidad de cerrar el diafragma de la cámara también se veía favorecida por el uso que hacía Bruch de placas ortocromáticas con la más suave gradación de contraste, que poseían buena flexibilidad luminosa; de muy buena calidad y sensibilidad próxima al rojo. Esta descripción de los recursos técnicos a los que apelaba Bruch resulta significativa ya que en un grado importante la calidad estética de su obra depende no sólo de las posibilidades sino también de las elecciones técnicas que haya tomado. En este sentido es bueno considerar estos detalles técnicos ya que uno de los rasgos que identifican a los fotógrafos documentalistas es su profundo conocimiento y dominio de las posibilidades y limitaciones del medio (Newhall 1938).

Como vimos a lo largo de este capítulo Bruch recorrió como empleado del Museo y como fotógrafo de la Comisión de Límites con Chile gran parte del territorio argentino y en todos los lugares que visitó lo hizo acompañado de una o varias cámaras registrando todo aquello que le parecía merecedor de ser fijado sobre la placa de vidrio. Al comenzar este capítulo hicimos referencia a la colección de diapositivas que Bruch ofrecía en venta al museo en 1910. Esas "vistas" y "positivos" continúan inéditas aún hoy y su desconocimiento por parte de los especialistas y del público no permite apreciar la obra fotográfica de Bruch en toda su dimensión. De este modo mientras que su actividad en la fotografía entomológica fue analizada y hecha pública únicamente por el citado artículo de Jörg, se estaba construyendo una mirada sesgada en el sentido de no tener en cuenta los materiales que fueron incluidos en este análisis. Las imágenes inéditas que Bruch obtuvo por ejemplo en el noroeste argentino mostrando sus viejas iglesias coloniales, en los paisajes naturales de Catamarca o Misiones, en las expediciones científicas que emprendió por cuenta del Museo, o en la comisión de Límites con Chile, entre los indígenas patagónicos o entre los chaqueños que se hallaban trabajando en la zafra, entre otras tantas, nos permiten reconocer en su fotografía un testimonio documental hasta ahora ignorado. 


\section{CAPÍTULO II}

\section{LA FOTOGRAFÍA COMO EVIDENCIA CIENTÍFICA Y COMO OBJETO DE INTERCAMBIO.}

En este capítulo, a través del análisis de dos casos, se trabajará sobre el papel de la fotografía como evidencia científica y como objeto de intercambio. En ese sentido haremos referencia al límite entre las llamadas fotografía "científica" y fotografía "comercial", partir del estudio de la amplia circulación que tuvieron las fotografías de un indígena guayaquí capturado en 1894 donde, según veremos, la fotografía iría a funcionar como evidencia científica. En este sentido se relacionará esta cuestión con el límite establecido entre lo "profesional" y lo "amateur" en el campo de la antropología de fines del siglo XIX, buscando mostrar que se trataba esta de una frontera ambigua y difusa. Por otra parte también buscaremos mostrar de que forma la fotografía era utilizada en tanto objeto de intercambio, circulando por las redes científicas de intercambio de fines del siglo XIX y principios del siglo XX. En este último punto enfocaremos en el caso de la colección fotográfica de Guido Boggiani editada por Robert Lehmann-Nitsche. Este ejemplo nos llevará a interrogarnos acerca de la definición de lo "antropológico" o "etnográfico", en lo que concierne a la fotografía. Finalmente, intentaremos mostrar como los debates que se daban al interior de la comunidad antropológica con respecto a los alcances y limitaciones de la fotografía aplicada a la actividad antropológica pueden aportar nuevos datos para comprender la concepción de la fotografía que se tenía en el período considerado.

\section{Los difusos límites entre la fotografía "comercial" y la fotografía "científica"}

Desde que comenzaron a imprimirse en 1897 y hasta mediados de la década de 1910 las tarjetas postales fotográficas ${ }^{1}$ se transformaron en un fenómeno de circulación masiva en Argentina, de forma que este período fuera caracterizado como "la época de

\footnotetext{
${ }^{1}$ Si bien las primeras tarjetas postales se comenzaron a utilizar en Viena en el año 1869 llegando a la Argentina en 1878, la tecnología necesaria para imprimir en ellas imágenes fotográficas no se desarrolló sino hasta mediados de la década de 1890.
} 
oro de la postal fotográfica" (Priamo y Alexander 1998: 30). Estas tarjetas estaban ilustradas con una diversidad de imágenes que representaban temas tales como paisajes, ciudades y edificios, escenas románticas y humorísticas, gauchos y por supuesto indígenas. En tanto una nueva forma de reproductibilidad técnica de la imagen fotográfica accesible al gran público, la tarjeta postal venía a reforzar el poder de la fotografía para acercar espacial y humanamente las cosas y los hombres lo que, según Walter Benjamin, se trataba de una aspiración de las masas tendiente a superar lo irrepetible de cada hecho recibiendo su reproducción (Benjamin 2005:100) ${ }^{2}$. En este sentido, dada la diversidad temática y gran popularidad de este medio podría decirse que a través de las tarjetas postales se conformó un mapa visual del país (Masotta 2005: 67).

A su vez, autores como Masotta, señalan que por intermedio de las postales que reproducían fotografías de indígenas y los comentarios expresados sobre ellos en epígrafes suplementarios o anotaciones manuscritas en las mismas tarjetas, se ejercía una "función etnográfica" determinada, en tanto conformaba una "etnografía del sentido común" (Masotta 2005: 75). En efecto, y tal como lo señalan Edwards y Hart, las inscripciones en el soporte físico de la imagen deben considerarse como formando parte de su materialidad y en tal sentido influirían en el modo en el cual ellas son observadas, indicando y determinando expectativas y patrones de uso específicos. Al prestar atención a la materialidad de la imagen estaríamos transformando la "fotografía", abstracta y representacional, en "fotografías", como objetos que existen en tiempo y espacio (Edwards y Hart 2004: 2-3).

Las "postales etnográficas" no solo estuvieron ligadas al gran público y el consumo masivo sino que también circularon por los canales de la antropología académica. Muchas imágenes fotográficas que fueron impresas y comercializadas en forma de tarjetas postales a principios del siglo XX sirvieron no solamente como ilustración sino

\footnotetext{
${ }^{2}$ Continuaba Benjamin señalando que: "Cada día se hace más inevitable la necesidad de adueñarse del objeto en la máxima proximidad de la imagen, o mejor dicho, en la copia, en la reproducción. (...) Quitarle la envoltura a cada objeto, hacer trizas su aura es el rasgo característico de un modo de percepción cuya "sensibilidad para lo igual en el mundo" se ha desarrollado tanto que hasta lo extrae de lo singular mediante la repetición." (Benjamin 2005 :100)
} 
que también fueron objeto de análisis y discusión en distintas contribuciones antropológicas. Además, las fotografías también podían ingresar en el sistema de intercambio científico a través de su publicación en diarios o revistas de circulación masiva que obtenían sus imágenes de un amplio rango de fuentes. Los antropólogos, al absorber en su colecciones y utilizar en sus discusiones y publicaciones este material, producido inicialmente con fines comerciales, le otorgaban en cierta forma una autoridad científica (Edwards 2001: 40). En este sentido puede entenderse que el límite entre las Ilamadas fotografía "científica" y fotografía "comercial", se vincula al límite establecido entre lo "profesional" y lo "amateur" en el campo de la antropología de fines del siglo XIX. Una frontera ambigua y difusa. Este doble valor que caracterizó a la fotografía durante el período estudiado; como objeto de consumo por un lado y como objeto de conocimiento por el otro; nos lleva a entender la delimitación de lo "antropológico" o "etnográfico", al menos en lo que toca a la fotografía, como una definición en parte fluida y azarosa ${ }^{4}$.

En este capítulo no discutiremos la historia ni las características particulares de la tarjeta postal ${ }^{5}$, sino que nos detendremos en el análisis de dos ejemplos de caso referentes a fotografías de indígenas que circularon tanto entre antropólogos y estudiosos de los pueblos indígenas sudamericanos como entre el gran público de fines del siglo XIX y principios del siglo XX en forma de tarjeta postal. Ambos casos, que involucran tanto al Museo de La Plata como a los pueblos indígenas del Gran Chaco, nos permiten observar las fronteras difusas que existieron entre las redes de circulación de la fotografía comercial y la fotografía científica, enfatizando en la utilización de la imagen fotográfica como objeto de consumo por un lado y como evidencia científica por el otro. De esta forma, un estudio empírico detallado de dos casos puntuales nos informa acerca del modo en que el intercambio de fotografías y

\footnotetext{
${ }^{3}$ Esta distinción entre fotografía comercial y fotografía antropológica no está pensada como una división entre dos géneros fotográficos diferenciados en cuanto a las temáticas que abordan o el modo en que lo hacen, sino más bien con el uso que se hacía de las fotografías, ya que como acabamos de señalar las mismas imágenes podían circular en los dos ámbitos.

${ }^{4}$ Como veremos más adelante en este capítulo los antropólogos de ese entonces eran conscientes de este doble uso "popular" y "académico" de las fotografías de indígenas, lo que muchas veces los llevó a discutir acerca de la validez científica de ciertas imágenes.

${ }^{5}$ Para una lectura acerca de la historia de las tarjetas postales fotográficas de indígenas (y también de gauchos y paisajes) en Argentina, remitimos a Masotta 2003 y 2005.
} 
postales fotográficas contribuye a comprender la cultura visual que sustentaba la antropología del siglo XIX (Edwards 2001).

Por otra parte entendemos que los ejemplos que aquí se presentan y analizan constituyen nuevos datos para estudiar la historia de la experiencia de observar fotografías científicas y decidir sobre su valor tanto como formas empíricas de representación como de piezas de evidencia científica. De acuerdo con Tucker (2005) se ha prestado poca atención a la microhistoria de los procesos sociales involucrados en la construcción de las fotografías como evidencia a través de diferentes niveles de producción cultural, desde los atlas científicos a las revistas periódicas. Esta autora, siguiendo las argumentaciones de John Tagg (1988) señala que la historia de la fotografía como evidencia científica debe comprenderse en el marco más amplio de las relaciones de poder, ya que la misma idea de qué constituye evidencia implica técnicas y procedimientos definidos, instituciones concretas y relaciones sociales específicas.

En primer lugar se analiza el caso de las fotografías tomadas en el Paraguay a un hombre -a quien se identificaba como perteneciente al pueblo indígena guayaquí ${ }^{6}$-, las que nos ofrecen la oportunidad poco frecuente de reconstruir el proceso de producción, circulación y recepción de una serie acotada de imágenes fotográficas utilizadas tanto por la fotografía comercial, en forma de tarjeta postal, como por la comunidad antropológica, en tanto evidencia de la existencia de los indígenas aché, de quienes se tenía poca información en ese momento. Estas fotografías, tomadas en 1894 por Charles de La Hitte, quien fue empleado de la Sección Antropológica del Museo de La Plata, circularon a nivel internacional durante cerca de una década ilustrando las discusiones que sobre esta cuestión se abrieron en el campo de antropología decimonónica. En este sentido, enfatizando en el papel de la fotografía en la

\footnotetext{
${ }^{6}$ El término "guayaquí" posee un carácter despectivo ya que significaría "ratón de monte" en lengua guaraní. Por ello, siempre que no citemos o nos expresemos con las palabras de otros autores, nombraremos a este pueblo como aché, que es el término como se designan a ellos mismos (Clastres 1967) y que significa "la gente, los de la palabra". Los aché son un pueblo indígena que vivía tradicionalmente de la caza y la recolección; habitaban, aproximadamente hasta la primera mitad del siglo XX, en las selvas subtropicales del este del Paraguay. Un territorio que se extendía entre $\operatorname{los} 24^{\circ}$ y $27.5^{\circ}$ de latitud sur, $54^{\circ}$ y $56.5^{\circ}$ de longitud oeste, abarcando no menos de 6 departamentos actuales de la región oriental del Paraguay (Canindeyú, Alto Paraná, Caaguazú, Guaira, Caazapá e Itapua) (Edeb Piragi 2001).
} 
construcción de los objetos científicos se discuten las posturas de los antropólogos de la época acerca de la relación entre fotografía y realidad.

El segundo de los casos a tratar comprende la llamada "Colección Boggiani", un conjunto de tarjetas postales del artista italiano Guido Boggiani, compiladas y editadas por Robert Lehmann-Nitsche como tarjetas postales en 1904 e impresas por la casa editora Rosauer, de Buenos Aires. Esa colección fue dividida en dos secciones, una colección principal que fue dirigida al público en general y un anexo destinado a los hombres de ciencia, que Lehmann-Nitsche se encargó de hacer circular por todo el mundo, obsequiándoselo a colegas, donándolo a instituciones y también entregándolo a quienes se las solicitaban. En este esquema de intercambios recíprocos, las fotografías, en forma de tarjetas postales, funcionaban como un vehículo de comunicación entre los estudiosos y los distintos círculos de individuos dedicados a la antropología, quienes las coleccionaban para formar acervos que permitían posteriormente la realización de estudios raciales comparativos a escala global (Edwards 2001). Por otra parte, poco tiempo después de publicada esta colección, y debido a ello, Lehmann-Nitsche tuvo un litigio sobre los derechos de propiedad de las imágenes con el explorador checo Alberto Vojtech Fric (1882-1944) (Penny 2002) quien se había convertido, luego de la muerte de Boggiani, en representante de los intereses de su familia en América. Este caso nos brinda un interesante ejemplo con respecto a los conflictos desatados en torno a la propiedad de las colecciones fotográficas, las cuales no solamente podían poseer un cierto valor científico sino que también eran objetos de los cuales podía obtenerse un rédito económico en un mercado internacional creciente y ávido de imágenes como era el de las tarjetas postales fotográficas. Como sucedía con otro tipo de objetos, el valor científico, por su parte, aumentaba el valor comercial de las colecciones (Cfr. Podgorny 2008)

\section{El "redescubrimiento de los guayaquíes"}

Los días 12 y 13 de febrero de 1895 el diario La Nación de Buenos Aires publicaba un extenso artículo titulado "Los Guayakíes. En plena selva. El Hombre Primitivo", firmado 
por el vizconde francés Charles de La Hitte (1856-1927) ${ }^{7}$, quien narraba las peripecias de su trayecto de ocho meses -entre abril y octubre de 1894- por las selvas orientales de Paraguay. En ese viaje, La Hitte había recolectado diferentes informaciones y elementos materiales pertenecientes a este grupo, quienes, según decía, habían sido "poco estudiados hasta hoy, y casi desconocidos aún para aquellas personas que se interesan por la suerte de las razas autóctonas sudamericanas." ${ }^{8}$ En efecto, la incursión de La Hitte derivó en lo que posteriormente Roberto Lehmann-Nistche denominaría "la primera investigación científica sobre la somatología y ergología de los indios Guayaquíes conocidos hasta aquella época casi sólo por el nombre" (Lehmann-Nitsche 1908: 91)

Según Lehmann-Nitsche (1908), las primeras referencias a este pueblo pueden hallarse a partir de la segunda mitad del siglo XVIII, en las crónicas de los jesuitas que actuaron en el Paraguay. Desde finales de ese siglo y hasta finales del siglo XIX los testimonios provienen no solo de misioneros de diferentes órdenes sino también de fuentes tales como exploradores, colonos, militares, y viajeros ${ }^{9}$. En muchas de esas crónicas se hacía referencia repetidamente a la "timidez" y carácter "huidizo" de este pueblo, como las causas por las cuales no habría sido posible obtener datos confiables acerca de ellos. Aunque varios naturalistas y exploradores de fines del siglo XIX mencionan su existencia, fueron en verdad muy pocos los que llegaron a enfrentarse cara a cara con ellos. Uno de los pocos testimonios de contacto visual con estos hombres, es el que nos brinda Jorge Masterman, farmacéutico militar del Hospital de Asunción durante la llamada Guerra de la Triple Alianza, quien pudo observarlos mientras se hallaba prisionero, describiéndolos, según La Hitte, "con el desprecio más

\footnotetext{
${ }^{7}$ Charles de La Hitte, un jurista francés de origen aristocrático y aficionado a los estudios de etnología, arqueología, lingüística e historia, llegó a Buenos Aires a principios de 1888. Según Vicente Cutolo (1975: 40), La Hitte vino a la Argentina impulsado por el "afán de investigación en el campo americanista". Hijo de la baronesa Joséphe de Leyniac y del Conde Odino du Cos de La Hitte, fue patrocinado por su padre y por el gobierno francés de ese entonces para realizar esta travesía.

${ }^{8}$ La Nación 12/02/1895

9 En 1800, el Padre Lorenzo Hervás, en su "Catálogo de las lenguas conocidas" anotaría algunos "apuntes vagos" que le había dado el Padre José Cardiel sobre este grupo. En 1861 el diario La Nación de Montevideo intentaría responder si este grupo llamado "guayaqui" por sus vecinos guaraníes, podía ser una rama de esta familia. (Pegoraro 2009: 121-122). Ramón Lista (1883) y Juan Bautista Ambrosetti (1894) se limitan a reproducir los relatos de los misioneros jesuitas en el primer caso, y de los yerbateros y colonos en el segundo.
} 
profundo y exageración preconcebida" (ten Kate y La Hitte 1897: 7) ${ }^{10}$. Alrededor de una década antes de que La Hitte realice su excursión por el Paraguay el marino italiano Giacomo Bove (1852-1887) se encontraba viajando -en 1883- por el territorio de Misiones donde tuvo ocasión de obtener la fotografía de un niño aché (Figura 1).

Figura 1. "Ubirateau. Guagiachil del Fiume Monday" (Bove 1885: 100)

Esta litografía, según nos dice Bove, fue realizada a partir de una fotografía que el Sr. Goicochea ${ }^{11}$, de la ciudad argentina de Corrientes, hizo sacar a un niño identificado como "guayaquí", y que se correspondería con una de las primeras imágenes publicadas de un indígena de ese pueblo. Bove se preguntaba "Como una población pudo mantenerse en tal estado, rodeada como está ella de una civilización si no europea, al menos

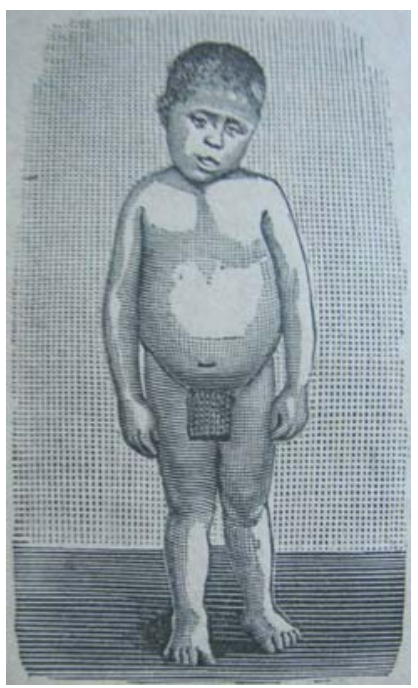
avanzada, es uno de esos misterios que la naturaleza no ha develado aún y que quizás no develará nunca" (Bove 1885:99, mi traducción). Este mismo autor nos indica en su relato que son los yerbateros ${ }^{12}$ quienes más frecuentemente tienen oportunidad de encontrarse con algún rastro de esos hombres, sin embargo, aún entre ellos son pocos los que se encontraron cara a cara con uno de estos indígenas.

En efecto, los conocimientos que se tenían eran escasos, fragmentarios y en muchas oportunidades poco fiables lo cual, según lo marcaba el propio La Hitte, se basaba en

\footnotetext{
${ }^{10}$ Dice Masterman: "Poco después, algunos Indios llamados los Guaiquis, habitantes de las grandes selvas al norte del Paraguay, fueron traídos á la Asunción, y habiendo sido atacados por las viruelas, el Dr. Rhind tuvo oportunidad para observarlos mientras yo estaba todavía preso en el Colegio. Parecían pertenecer al tipo mas infimo de la especie humana; su poca estatura, su cutis casi negro, sus flacos y delgados miembros, me recordaban desagradablemente á los monos; su inteligencia parecía ser inferior á la de estos animales. No construyen cabañas, ni llevan ropa, ni conocen el uso del fuego; viven en las selvas y se alimentan de frutos y raíces, á veces roban las gallinas de los colonos establecidos en su vecindario y las comen crudas; los soldados dijeron al doctor, que si los emborrachaban no se les ocurrirían para escaparse otros medios que los que emplearían las vacas en idéntica situación. No parecen tener un lenguaje articulado..." (Masterman 1870: 183-84)

${ }^{11}$ Según Ambrosetti, "El Sr. D. Juan Goycochea, cuando trabajaba en el Monday consiguió un pequeño Guayaquí que crió hasta hace poco. Este indio se hallaba en Posadas, pero desgraciadamente, en el poco tiempo que estuve allí no lo pude ver" (Ambrosetti 1894:112)

12 Trabajadores de las explotaciones de yerba mate.
} 
la ausencia de "hechos positivos" que dieran cuenta de ese pueblo ${ }^{13}$. Por otra parte, la reticencia a entrar en contacto con la sociedad blanca y con otros pueblos indígenas vecinos había conseguido que los guayaquíes fueran considerados dueños de un inalterado carácter "salvaje", transformándolos de esa manera en una incógnita a resolver para los estudiosos. Según manifestaba el propio La Hitte, ese pueblo mantenía "sin alteración alguna, el carácter y las costumbres del salvaje primitivo, y es por ese motivo que merecen, más que otros, atraer especialmente la atención del curioso y del etnólogo." ${ }^{14}$ Seguidamente, este autor aventuraba una hipótesis explicativa acerca de su origen, emparentándolos con "los naturales más primitivos" del planeta, al tiempo que finalizaba su artículo apelando al conocimiento de los etnólogos para descifrar este nuevo enigma, diciendo: "Dejo a los sabios y a los eruditos el cuidado de contestar". ${ }^{15}$

De esta forma La Hitte remarcaba un límite que existía para entonces en el campo de la antropología, entre la recolección de los datos y su interpretación, colocándose en el lugar de uno de los tantos proveedores de datos en esa empresa colectiva de observación del mundo y de la naturaleza.

\footnotetext{
13 “... no es de extrañar que los guayaquíes hayan dado lugar a numerosas leyendas populares extrañas e inverosímiles, que contribuyen a extraviar la opinión acerca de ellos, y hasta a veces ha hecho que se pusiera en duda su misma existencia, por aquellos que habiendo oído hablar de ellos en el Paraguay, no han tenido ocasión de encontrarse en presencia de hechos positivos, bastante escasos por cierto, por medio de los cuales se manifiestan." [LN 12/02/1895]

${ }^{14}$ La Nación 12/02/1895.

15 "Ahora para terminar, es el caso de preguntarnos si los guayaquíes han preexistido siempre en esa parte del Paraguay, y si los grandes exploradores de los siglos pasados, los compañeros y los émulos de los Solís y Cabeza de Vaca los han señalado, a estos o a sus semejantes en las narraciones de sus viajes.

Se sabe que los indígenas hallados por los primeros navegantes en el continente americano tenían cierto grado de civilización, muy adelantada entre los indios del Perú y de Méjico; por fin, que los guaraníes, tribus consideradas inteligentes, fueron con facilidad accesibles a las ideas del cristianismo predicado por los jesuitas.

¿Debemos sacar la conclusión de que los guayaquíes no pertenecen a la familia de los guaraníes, o que representan alguna fracción retrógrada al estado primitivo por causa de un aislamiento secular?

Dejo a los sabios y a los eruditos el cuidado de contestar." [LN 13/02/1985]
} 


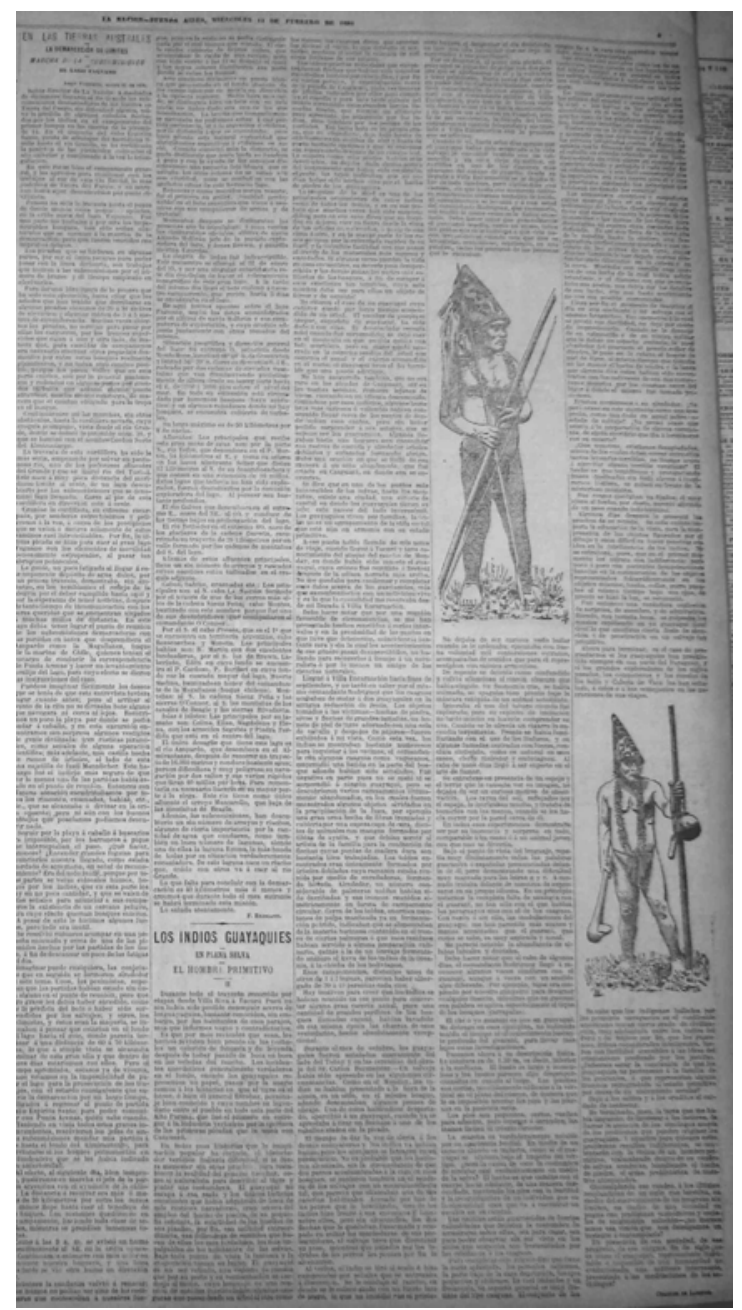

Figura 2. "Los indios Guayaquíes. En plena selva. El hombre primitivo" La Nación, miércoles 13 de febrero de 1895. Las dos litografías que acompañan esta nota fueron hechas a partir de las fotografías tomadas por La Hitte en 1894.

Este artículo logró una buena repercusión tanto a nivel nacional como internacional, propiciando el inicio de una discusión en torno a lo que podría llamarse "cuestión guayaquí", que se extendió por más de una década y donde participaron varios etnólogos alemanes, exploradores, colonos y misioneros. Las razones por las cuales esta comunicación tuvo, a diferencias de noticias anteriores, resonancias a nivel internacional, son difíciles de establecer, aunque es posible pensar que lo que sucedió una vez concluido el viaje de La Hitte por los yerbales del Paraguay tuvo algo que ver con ello. Una vez regresado de su largo periplo por los yerbales y selvas paraguayas, La Hitte pudo observar y fotografiar a un indígena aché que se hallaba prisionero en la ciudad paraguaya de Villa Encarnación. Esas fotografías fueron consideradas por él mismo como “... las primeras quizás, que se hayan obtenido de un individuo de esa raza, para ser entregadas a la consideración de los etnólogos." ${ }^{16}$ (Figura 2). Desde su aparición en esta publicación las fotografías tomadas por La Hitte comenzaron un periplo por diferentes contextos, soportes y formatos; siendo incluidas en publicaciones científicas, manuales escolares, diarios, revistas, fue editada en forma de tarjeta postal, como "Recuerdo de la República Argentina. Indio del Chaco" (Figura 3) y se ofreció también a la venta en un local de fotografía comercial de Buenos Aires.

\footnotetext{
${ }^{16}$ La Nación 12/02/1895
} 
Tal como puede leerse en una nota incluida al final de la primera entrega de la comunicación de La Hitte del 12 de febrero de 1895 que decía: "Se puede adquirir una fotografía de este indio, en la casa de A. Boote. Cuyo 767.". Arthur Wood Boote y Cía. era una casa fotográfica que se encontraba activa al menos desde 1894 dedicándose mayormente a la edición de álbumes de fotografía (Gómez 1986). Sin embargo, no es probable que esa imagen haya estado desde ese momento impresa en forma de tarjeta postal ya que ese formato comercial comenzó a surgir en Buenos Aires recién alrededor de 1897 (Priamo y Alexander 1998). De acuerdo con Epifanio (1994), Boote trasladó su comercio a la calle Florida 233 de Buenos Aires en 1898, allí ofrecería un amplio surtido de vistas del país junto con otras del Paraguay, Montevideo y Brasil, además de distintas escenas de campo. Pero ya en 1902 había abandonado la fotografía para dedicarse primero al negocio de la librería y luego a la venta de máquinas de escribir (Epifanio 1994: 76-77).

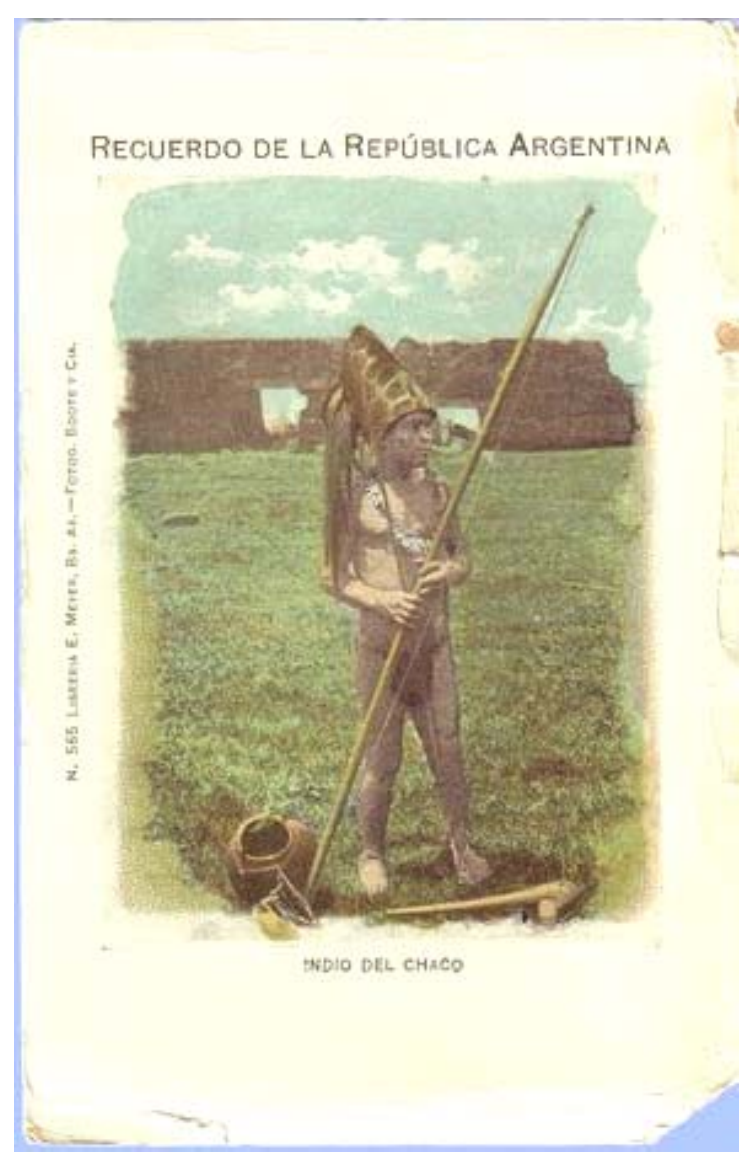

${ }^{17}$ La Nación 12/02/1895
Figura 3. "Recuerdo de la República Argentina. Indio del Chaco. N. 565 Librería E. Meyer, Bs. As.-Fotog. Boote y Cía.", (Tarjeta postal coloreada, c. 1900, Librería Meyer, Bs. As.)

Las fotografías tomadas por La Hitte eran, además y según el mismo declaraba, las primeras fotografías de un grupo indígena que, "Por numerosos rasgos de analogía, se los podría poner en parangón con los naturales más primitivos de algunas islas de Oceanía, del centro de África o de las regiones más inaccesibles de las penínsulas asiáticas.

Lo mismo que éstos, pueden considerarse como las últimas reliquias de la humanidad primitiva de la edad de piedra, del troglodita, nuestro antepasado de Europa, desaparecido hoy."17

Vemos aparecer en esta cita una 
preocupación extendida en la antropología de fines del siglo diecinueve en relación al origen de los pueblos indígenas americanos y que llevaba a buscar elementos en común entre estos pueblos y los del Viejo Mundo e incluso Asia. Estos "rasgos de analogía" estaban referidos básicamente a los rasgos físicos -sobre todo su relativamente pequeña estatura y la relativa inaccesibilidad del territorio ocupado por esos pueblos. La Hitte pretendió de esa forma contribuir con nuevos materiales a una discusión mayor que se venía desarrollando desde el último cuarto del siglo XIX dentro de la antropología europea, en relación a los orígenes y vinculaciones de las "razas pigmeas" constituyendo lo que Ballard llamó el "problema" o la "cuestión pigmea" (Ballard 2001: 134). En un contexto académico donde figuras como W. H. Flower (1831-1899) en Londres, A. de Quatrefages (1810-1892) en Paris, A. C. Haddon (18551940) en Cambridge y el padre W. Schmidt (1868-1954) en Viena se ocuparon de enunciar las características diagnósticas del físico y la cultura de estos pueblos, avanzando colectivamente en la definición de una "raza global de Pigmeos" (Ballard 2001:141). Para estos estudiosos los pigmeos representaban los resabios del más temprano estrato humano que se haya dispersado a través del mundo, y en consonancia con ello los indígenas aché eran para La Hitte, "reliquias de la humanidad primitiva". De este modo, las nuevas noticias sobre este grupo, eran noticias acerca de los supuestos posibles representantes sudamericanos de esa antigua "raza perdida" u "hombres de la edad de piedra".

Por otra parte, los guayaquíes se transformaron en un tema de interés en la agenda de los estudios americanistas no sólo por sus características físicas y las de su cultura material sino también, como marcamos más arriba, por que los datos que daban cuenta de esas características y la forma en que habían sido obtenidos eran cuestionados con frecuencia. De esta forma los indicios materiales, los "hechos positivos", entre los cuales podemos incluir las fotografías tomadas por La Hitte en 1894, se transformaron en testimonio de esa sociedad (Cfr. Pegoraro 2009: 231-232). Teniendo en cuenta este marco es posible entender que esas "primeras fotografías" fueron consideradas de interés para la antropología, una aceptación dentro de ese campo que se hace notoria además si atendemos a la duplicación de las mismas imágenes en diferentes 
publicaciones especializadas lo cual, según señala Edwards, era una medida del suceso de esta clase de imágenes, donde jugaban un rol central las de redes de intercambio (Edwards 2001:42).

Es interesante notar que al trabajar sobre la reconstrucción histórica de la cuestión guayaquí nos fue posible identificar el funcionamiento de una extensa red de relaciones sociales entre distintos actores que pertenecían a la comunidad germano hablante. Esta red incluía a colonos como Baldomero Schulz, quien ya en 1894 había publicado una noticia sobre los guayaquíes en la revista Paraguay Rundschau ${ }^{18}$, Carlos Baumeister, cuyos empleados capturaron al indígena guayaquí que La Hitte fotografió en 1894, y finalmente a Federico Mainthzusen (1911, 1945), colono afincado en Yaguarazapá (Alto Paraná, Paraguay) que produjo algunos textos sobre los aché meridionales que empleaba en sus explotaciones y a quienes había intentado reducir sin éxito (Vellard 1934: 223). Entre los misioneros, encontramos a Federico Vogt (1902, 1903, 1904 y 1911) de la orden católica Societas Verbi Divini. A esta sociedad, fundada en Holanda en 1875, pertenecía Wilhelm Schmidt, editor de la revista Anthropos y quien había trabajado intensamente con los pigmeos africanos (Marchand 2003). También debemos incluir a funcionarios gubernamentales como Henry Mangels, canciller alemán en el Paraguay, quien publicó sobre ese pueblo en Paraguay Rundschau (1895). Finalmente entre los antropólogos se suman Karl von de Steinen (1895, 1901), Paul Ehrenreich (1898, 1904, 1906), Theodor Koch-Grünberg (en Vogt 1902), Hans Virchow (1908) que se ocuparon de este pueblo desde sus lugares de trabajo en Europa; en tanto que desde América lo hicieron Herman von Ihering (1895) en San Pablo, Brasil y Roberto Lehmann-Nitsche (1899a, 1899b, 1908) en Argentina.

El primero de estos especialistas en ensayar una respuesta al interrogante planteado por La Hitte fue Karl von den Steinen, en una comunicación titulada Steinzeit-Indianer in Paraguay (Indios de la Edad de Piedra en Paraguay), publicada en la revista alemana Globus en abril de 1895. Allí se encargaba, además, de reproducir en forma

\footnotetext{
${ }^{18}$ Esta era una publicación en lengua alemana llevada adelante por colonos de esa nacionalidad establecidos en Paraguay, con la intención de difundir "información exacta" acerca de ese país (Bulletin of the American Geographical Society, Vol. 37, No. 7 (1905), p. 447, mi traducción)
} 
sintética las noticias traídas por La Hitte desde Paraguay para un público europeo ávido de novedades geográficas de todo el mundo. Von den Steinen, como destacarían sus necrológicas, representaba una autoridad en cuanto a la etnología de Sudamérica, figurando entre "los grandes nombres de la moderna exploración antropológica del Amazonas" (Gillin 1940: 646) En ese artículo, donde según Ehrenreich se demuestra "la importancia de ese descubrimiento"19, no se incluyeron imágenes, aunque si se hace referencia a las litografías publicadas en La Nación diciendo que se trataba de "dos reproducciones muy defectuosas" (Steinen 1895: 249). Este autor se lamentaba de la poca información lingüística que La Hitte había logrado obtener, lo cual hacía imposible clasificar a los aché. Von den Steinen se encarga además de traer las primeras referencias que sobre los aché brindaron quienes habían recorrido esa región, como los jesuitas de los siglos XVII y XVIII, y el explorador francés Castelnau en la primera mitad del siglo XIX. Finalmente señala que ese era el momento para visitar las "pequeñas tribus" que todavía no habían sido afectadas por la civilización en Sudamérica, poniendo como ejemplo a los Bugres (Xokleng) de Santa Catarina, Brasil quienes a pesar de que podían ser contactados fácilmente por los colonos alemanes de esa región permanecían aún desconocidos (Steinen 1895: 249). En esta última afirmación podemos identificar dos cuestiones que organizarían los debates etnográficos a inicios del siglo XX, que fueron por un lado el interés por llenar los vacíos del mapa etnográfico sudamericano y por otro la "urgencia" tanto por registrar como por coleccionar objetos pertenecientes a aquellos pueblos indígenas que se veían como "razas en desaparición" (Podgorny 2002; Pegoraro 2009).

\section{El Museo de La Plata y la "cuestión guayaquí"}

El Museo de La Plata estuvo dedicado a la recolección de objetos pertenecientes a los guayquíes casi desde sus inicios como institución. Armand de Bourgoing, quien se hallaba en la zona de Misiones recolectando materiales etnográficos y antropológicos a pedido de Francisco Moreno, había enviado allí un cráneo de un individuo de ese

\footnotetext{
19 En alemán en el original: „Die Bedeutung dieser Entdeckung wurde damals von Karl von den Steinen in einem ausführlichen Berichte dargelegt" (Ehrenreich 1898: 73)
} 
pueblo indígena a mediados de $1887^{20}$. También Juan Bautista Ambrosetti, remitió un hacha de piedra que había logrado obtener en uno de sus varios viajes al Paraguay y Misiones ${ }^{21}$. Pero el avance más significativo en este terreno tuvo lugar en noviembre de 1895 cuando Charles de La Hitte, algunos meses después de publicar las crónicas de su encuentro con el indígena aché en el diario La Nación, ingresó a aquella institución en carácter de segundo preparador de la sección antropológica. Junto con él ingresaron los objetos aché que había recolectado y que pasarían a formar parte permanente de las colecciones del museo. Es probable que esta incorporación se tratase de una nueva negociación de Moreno, donde el empleo en la institución provincial estaba mediado por la entrega -donación o venta- de la colección.

Luego de un viaje a Tierra del Fuego junto a Fernand Lahille, jefe de la sección zoológica del museo, donde, entre otros trabajos, se tomaron un conjunto de fotografías a indígenas Selk'nam (Lahille 1926), Charles de La Hitte volvería, hacia fines de 1896 y principios de 1897, al este de Paraguay en busca de nuevos datos. Esta vez acompañando al jefe de la sección antropológica, el antropólogo holandés Hermann ten Kate a quien, según La Hitte, se debe la iniciativa de este viaje (ten Kate y La Hitte 1897:5). Ten Kate realizó algunas comunicaciones preliminares sobre este viaje (ten Kate 1897a y 1897b) publicándose los resultados finales en los Anales del Museo de La Plata, bajo el título "Notes ethnographiques sur les Indiens Guayakí".

En la primera parte de este trabajo La Hitte se encargó de hacer una revisión bibliográfica, una descripción de algunas de sus costumbres -según lo que pudo observar en sus dos viajes-, junto con un pequeño vocabulario y una descripción de los objetos recogidos. Este último viaje no resultó tal como lo esperaban, debido en parte a las fuertes lluvias debieron circunscribir sus investigaciones a la zona comprendida

\footnotetext{
${ }^{20}$ Este explorador, que había hallado ese cráneo a mediados de 1887, en cercanías de las ruinas de la antigua misión jesuítica de Jesús, en el este de Paraguay no había establecido contacto con los aché, y reproducía al igual que en los casos de otros exploradores y naturalistas mencionados anteriormente un juicio bastante extendido sobre ellos: "En los montes de esas inmediaciones [Jesús] habitan algunas escasas tribus errantes de indios guayaquíes, séres desgraciados que, al decir de los naturalistas representan aún en nuestros días la "Edad de Piedra", pues, en efecto se sirven como en aquellos tiempos de infancia de la Humanidad, de utensilios de piedra: sus instrumentos cortantes, hachas, etc., son de esta materia." (Bourgoing 1894: 419)

${ }^{21}$ Esa hacha le había sido obsequiada por el Sr. Joaquín Aramburú de Posadas (Ambrosetti 1894: 111)
} 
entre las antiguas misiones jesuíticas de Trinidad y Jesús. Allí visitaron un campamento abandonado tres meses atrás ${ }^{22}$, y luego examinaron, midieron y observaron a tres jóvenes guayaquíes capturados en distintos momentos por colonos de la zona. Visitaron además una población de indígenas cainguá que habitaban en las mismas regiones selváticas de Paraguay, entre quienes realizaron algunas observaciones antropológicas y tomaron fotografías.

De esta forma, no obstante los propósitos iniciales del viaje sus resultados no arrojaron los avances que se esperaba, dada la imposibilidad de establecer contacto con ellos y la insuficiencia de los vocabularios recogidos, los cuales fueron apuntados de boca de los niños cautivos, lo que les otorgaba un dudoso valor en tanto fuentes de información ya que los mismos se hallaban viviendo entre la población blanca del Paraguay donde se hablaba el español y el guaraní lo que se presumía podía "desnaturalizar" su lengua materna. Los datos más novedosos que aporta La Hitte provienen de los objetos de la cultura material que se recolectaron, entre los cuales llamaron su atención los cestos de fibra vegetal recubiertos de cera que él señala como una las más primitivas formas de alfarería, que marcarían la transición de la cestería a la alfarería. En ese sentido estos objetos, debido a su "poca variedad, sencillez extrema y sobre todo, esta ausencia de búsqueda artística que ninguna tribu salvaje, en ningún punto del globo, presenta" (ten Kate y La Hitte 1897:22, mi traducción) lo llevan a equipararlos, nuevamente, con otros pueblos de Asia y Africa (como los Mincopies, Akka y Negritos), considerados como "ejemplos análogos de supervivencia de razas primitivas que, como los Guayaquis, son de pequeña talla, viven en los bosques, conservan sus costumbres salvajes, y desaparecen delante del elemento invasor que las rodea y al que no se agregan" (ten Kate y La Hitte 1897:22, mi traducción).

\footnotetext{
${ }^{22}$ Es en este viaje que como resultado de la persecución que asoló a los Guayaquies, La Hitte y ten Kate dicen haber encontrado abandonada a la niña, que traída al Museo, sería bautizada luego como Damiana. La trágica historia de Damiana finaliza cuando muere aproximadamente a los 14 años luego de haber sido internada en el Hospital de Melchor Romero (La Plata). Su cuerpo fue llevado al Museo de La Plata -sin el cráneo que aún se encuentra en Alemania a donde fue enviado para su estudio-. Atendiendo a la solicitud de los referentes aché del Paraguay (Cfr. Pepe 2008), los restos de Damiana fueron restituidos por el museo en una ceremonia especial que se realizó en junio de 2010, en el marco de la política de restitución de restos llevada adelante por esa institución (Tamagno 2009)
} 


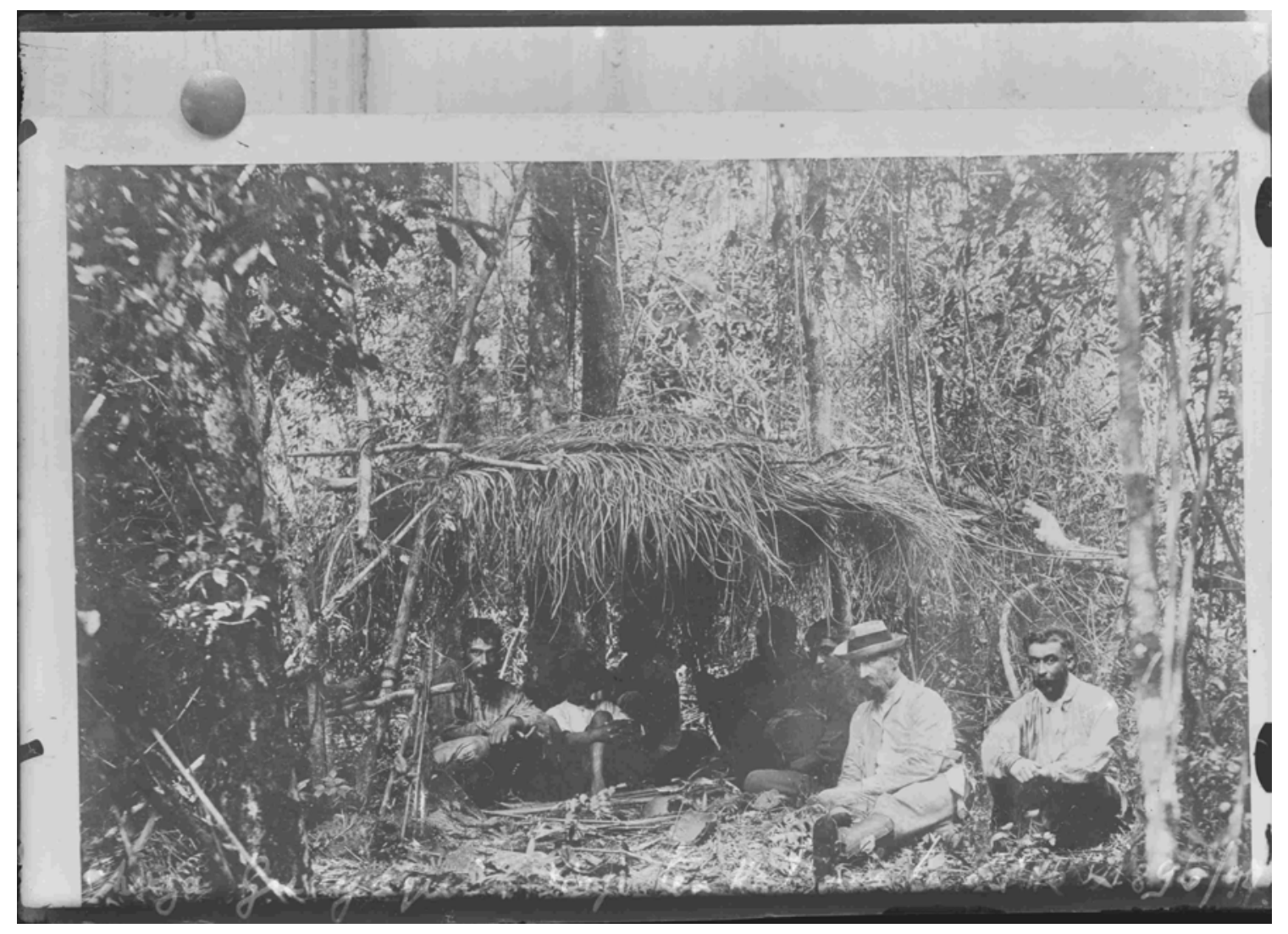

Figura 4. "Choza guayaquí Viaje ten Kate de La Hitte 1896-97" (Inscripción original) (La Hitte-ten Kate, montaje fotográfico, negativo de vidrio $13 \times 18 \mathrm{~cm}$.) (AHFMLP-ARQ-002-023-0004). De derecha a izquierda, Charles de La Hitte, Hermann ten Kate (con sombrero) y sus acompañantes.

En esta fotografía podemos observar como la figura de La Hitte resalta con respecto a las demás, dejando en evidencia que no pertenece a la imagen original. Este montaje fue realizado a partir de otras dos fotografías. Una de ellas que aquí se utilizó como matriz, fue tomada por La Hitte, y muestra a ten Kate a la derecha junto a sus acompañantes. En la otra foto, tomada por ten Kate, aparece La Hitte a la izquierda.

La segunda parte del trabajo, escrita por Hermann ten Kate y donde se resumían los resultados obtenidos en el viaje de 1896-97, estaba dedicada a la antropología, específicamente a las mediciones hechas sobre un esqueleto ${ }^{23}$ y sobre los niños cautivos. Allí ten Kate comenzaba señalando que "Si la etnografía de los guayaquis es muy poco conocida, la antropología física de estos Indios está en el estado de desiderátum para la ciencia" (ten Kate y La Hitte 1897: 25), para posteriormente describir los resultados de sus estudios y mediciones antropométricas que fueron

\footnotetext{
${ }^{23}$ Este esqueleto fue desenterrado por ten Kate y La Hitte el 29 de diciembre de 1896 y pertenecía a una mujer guayaquí que fue muerta por un grupo de colonos que era a su vez la madre de la niña llevada al Museo y bautizada Damiana.
} 
realizados de acuerdo a la escuela de antropología francesa, siguiendo particularmente a Broca, Topinard y Manouvrier.

En sus conclusiones, ten Kate los relaciona con un tipo "paleoamericano" braquicéfalo cuyo representante más antiguo estaba en un cráneo "atípico" hallado en Lagoa Santa, Brasil. Dentro de un grupo donde también incluye a los tipos sub-braquicéfalos de pequeña talla estudiados por von den Steinen, a otros encontrados en la Guayana, y a los cainguá. En ese sentido para este antropólogo los guayaquíes estaban representado "el grupo más austral, los menos numerosos, más homogéneos y los más primitivos posiblemente de esta antigua raza de hombres dispersada en las inmensas soledades silvestres de América del Sur." (ten Kate y La Hitte 1897:38, mi traducción).

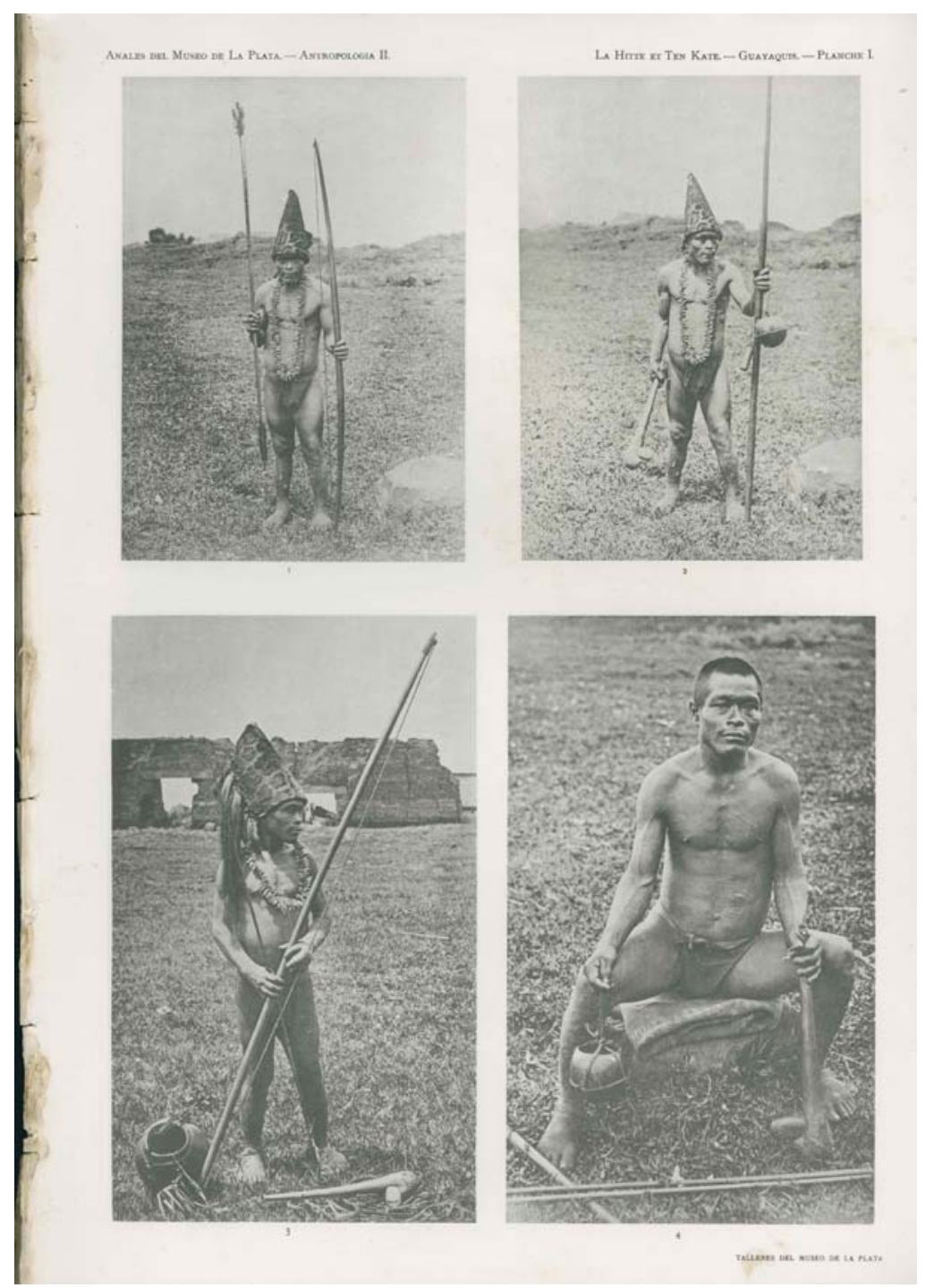

Figura 5. "Notes etnographiques sur les Indienes Guayaquis" Plancha I, Anales del Museo de La Plata, Sección Antropología II, 1897.

A pesar de que al inicio de este trabajo La Hitte señalaba que el artículo salido en La Nación en febrero de 1895 no tenía "otro mérito que poder servir de punto de partida al estudio etnográfico de los Guayaquis" (ten Kate y La Hitte 1897:5), se volvieron a utilizar aquí las fotografías que ya habían sido publicadas en ese entonces, tal vez debido a los pocos resultados obtenidos en este nuevo viaje, particularmente a 
que no habían podido estudiar a un individuo adulto. Por ello se reprodujeron cinco imágenes tomadas al indígena capturado en 1894, cuatro de estas imágenes, donde este hombre aparece acompañado por objetos y adornos relacionados a los aché se reprodujeron en la plancha 1 de esa publicación (Figura 5), en la restante fotografía se lo ve vestido con uniforme militar, descalzo y portando un fusil junto al Sr. Rodríguez jefe político de Villa Encarnación. Como dijimos es posible que estas fotografías hayan sido publicadas para suplir en cierto modo la ausencia de mayores datos, ante las dificultades que habían enfrentado, para conseguir materiales confiables, y al no poder dar con los guayaquíes en su propio territorio. Es así que ten Kate refiere a "las bellas fotografías del prisionero adulto tomadas por M. de La Hitte, en 1894" para "formarse una idea de los caracteres físicos de este Indio." (ten Kate y La Hitte 1897:34) Y señala posteriormente su pequeña talla en relación al Sr. Rodríguez, la cual según recuerda La Hitte era de $1520 \mathrm{~mm}$. Además, la fisonomía de su rostro le recuerda a las fotografías de Botocudos (Xokleng) que había observado mientras estuvo en la Sociedad Antropológica de Paris, aunque al examinarlo de perfil le recuerda a un habitante de Papúa (ten Kate y Lahitte 1897:34).

De esta forma, dadas las dificultades que se planteaban a los investigadores no ya para estudiar a los guayaquíes sino siquiera para llegar a hacer contacto visual con ellos, las fotos tomadas por La Hitte en 1894 cobraron un valor científico inesperado, ya que es posible que objetivo original haya sido simplemente comercializarlas. Recordemos que una copia de ellas se ofrecía en la casa fotográfica de Arthur W. Boote en Buenos Aires y que para ese momento La Hitte no era empleado del Museo de La Plata. De esta forma se privilegió el contenido de la imagen por sobre su forma y sus circunstancias de producción, y el hecho de que hayan sido reproducidas en los Anales del Museo de La Plata y en el trabajo de Paul Ehrenreich en la revista científica Globus, entre otros, las recubrió en cierta forma de autoridad antropológica, en el sentido en que lo plantea Edwards (2001).

Justamente este último antropólogo se refería a las fotografías de La Hitte que el reproduce en su artículo, señalando que esas "magníficas ilustraciones representan un 
progreso de nuestro conocimiento" (Ehrenrecih 1898: 73, mi traducción), remarcando además que La Hitte sería el segundo testigo ocular de los guayaquíes (contando al inglés Mastermann como el primero), aunque la fotografía del hombre capturado en Encarnación en 1894 sería la primera imagen de un indígena guayaquí adulto. A su vez Ehrenrecih brinda algunas noticias anteriores al primer viaje de La Hitte, cuando en 1899 el pintor y fotógrafo berlinés Karl Oenike (1862-1924) junto al naturalista austríaco Paul Jordan escalaron el Cerro Tatuy en busca de ellos, aunque solo pudieron hallar algunos rastros de sus habitaciones que Oenike dibujó. Este dibujo también fe reproducido por Ehrenreich en 1898.

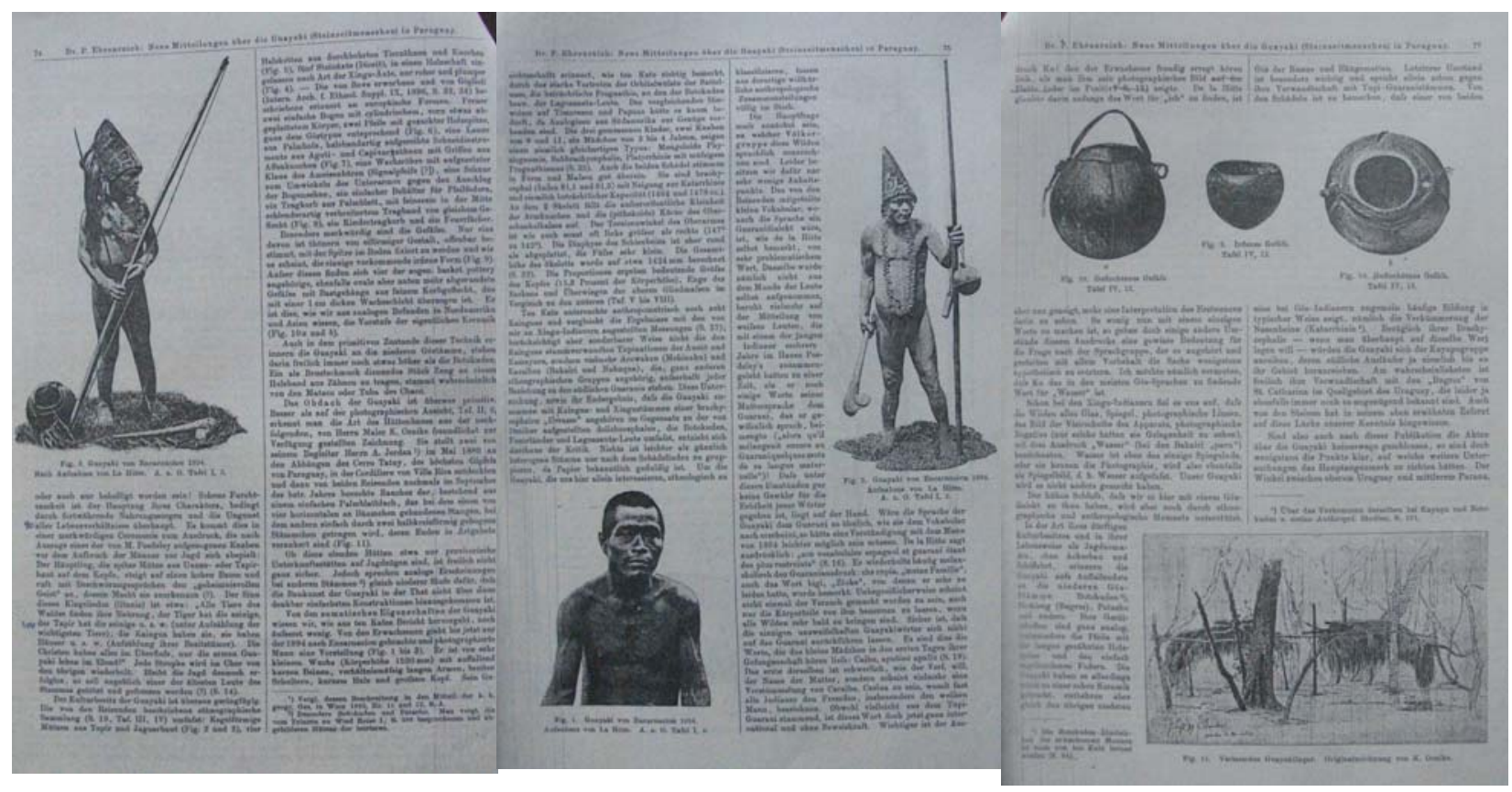

Figura 6. Páginas 74, 75 y 77 de la publicación de Paul Ehrenreich en Globus (1898)

Aunque coincide con ten Kate en cuanto a las similitudes que este establece entre Guayaquis y Botocudos (Xokleng) por sus caracteres físicos, no se muestra de acuerdo con hacer comparaciones a nivel regional basándose solamente en el índice cefálico ya que estas, señala, pueden resultar engañosas (Ehrenreich 1898: 75). Por ello propone como primera medida realizar comparaciones lingüísticas para clasificar a los guayaquíes. En ese sentido vuelve a marcar el problema de los datos lingüísticos obtenidos los cuales son escasos y a veces problemáticos, poniendo como ejemplo a 
los niños de quienes ten Kate obtuvo el vocabulario publicado en 1897, haciendo notar que ellos hacía ya algunos años vivían en casa del colono Posdeley por lo que su vocabulario no era "genuino" (Ehrenreich 1898). Esto no le impidió sin embargo formular una arriesgada hipótesis sobre su posición etnográfica basándose en un solo término de su vocabulario. Entre las palabras registradas por La Hitte en 1894 se encontraba el término "Ku", que fue la expresión registrada cuando se le mostró su retrato fotográfico al aché que se hallaba prisionero. Por ello La Hitte tradujo esta palabra en primer lugar como "yo", aunque después señalaría que este término era una exclamación de sorpresa del indígena al descubrirse representado en la fotografía. Sin embargo, Ehrenreich señala que en realidad ese término podría significar "agua", habiendo sido utilizada al ver su imagen reflejada en la fotografía. El término "Ku" significa justamente "reflejo" entre los pueblos Xingú de Brasil -del tronco lingüístico Gé- y es utilizado para referirse indistintamente al vidrio, espejo, lente fotográfico, a la imagen del visor de la cámara e incluso a los negativos fotográficos (Ehrenreich 1898: 77). Por medio de esta última hipótesis, Ehrenreich aportaba, además de los datos provenientes de los índices craneanos y la cultura material, un apoyo lingüístico para vincular a los aché con los Botocudo (Xokleng) del sur de Brasil, comprendidos dentro del tronco lingüístico $\mathrm{Gé}^{24}$ y también considerados entre los pueblos más primitivos del planeta.

Estas y otras hipótesis podrían comprobarse o rechazarse para Ehrenreich en tiempo no muy lejano ya que, según señalaba al final de su artículo, podría esperarse de las "fuerzas activas del Museo de La Plata" nuevos avances en este campo de la etnografía (Ehrenreich 1898: 77). Sin embargo, esos avances nunca se produjeron, poco después de realizarse la publicación de 1897 Hermann ten Kate abandonó el Museo de La Plata para trasladarse a Japón, mientras que Charles de La Hitte sería exonerado hacia fines de ese mismo año ${ }^{25}$. Por otra parte, mientras los mayores

\footnotetext{
${ }^{24}$ Posteriormente se comprobó que la lengua guayaquí pertenece al tronco lingüístico Tupí-guaraní dentro del cual se sigue clasificando actualmente (Fabre 2005)

${ }^{25}$ Decía Francisco Moreno en carta al Ministro de Obras Públicas de la provincia de Buenos Aires del 15 de octubre de 1897: "El Segundo Preparador de este establecimiento Don Carlos de Lahitte se ha negado terminantemente á obedecer mis disposiciones reglamentarias respecto á asistencia de empleados y además no obedece las órdenes, que se le dán como Segundo Preparador, lo que motiva repetidas quejas del Jefe de la Sección Antropológica [R. Lehmann-Nitsche] en la que debe servir. No siendo posible continuar soportando estas desobediencias que
} 
esfuerzos de Francisco Moreno estarían dedicados a las trabajos en la demarcación de límites con Chile, la sección antropología sería dirigida desde julio de 1897 por Robert Lehmann-Nitsche quien, a diferencia de ten Kate, desarrollaría una obra de comentario y traducción (Podgorny 2005) relegando las investigaciones en el campo a un lugar secundario, al menos durante sus primeros años de actividad en La Plata.

Aunque esto no significó el abandono inmediato de la "cuestión guayaquí", la cual sería abordada por el mismo Lehmann-Nitsche varias oportunidades (1899a, 1899b, 1903 y 1907), por el misionero Federico Vogt (1902, 1903 y 1904) y por el colono alemán Federico Mayntzhuzen (1911), se reproduciría la forma de trabajo aplicada en las anteriores contribuciones sobre el tema, las cuales trabajaron en su gran mayoría con indígenas aché capturados por colonos y habitantes de las regiones contiguas ${ }^{26}$. El fuerte interés que la comunidad antropológica mundial había prestado a este tema desde mediados de la década de 1890 comenzó a perder fuerza en forma paulatina, a juzgar por el número de publicaciones al respecto en las revistas científicas nacionales e internacionales que se vio reducido notablemente para la década de $1910^{27}$.

\section{La serie fotográfica de 1894 y su trayectoria}

Ya entrado el siglo XX las fotografías de La Hitte continuaron circulando por distintos medios. El misionero de la Sociedad del Verbo Divino, Federico Vogt utilizó dos de esas fotos en su publicación en el Zeitschchrift für Ethnologie de 1902 (ese artículo incluía al final una colaboración del reconocido antropólogo Theodor Koch-Grünberg). En 1904 el zoólogo italiano Enrico Giglioli publicó una pequeña comunicación sobre los aché en la revista inglesa Man donde utilizó una de estas fotografías. En 1910

perjudican á la buena disciplina del establecimiento, pido á V. S. quiera separar de su puesto a dicho empleado." (AHPBA, Ministerio de Obras Públicas, Letra M, N²47)

${ }^{26}$ La única excepción sería la de Federico Mayntzhusen quien había logrado reducir un grupo de guayaquíes que trabajaba en sus colonias, sin embargo esta "reducción" sólo duró hasta 1914. Por otro lado el Padre Vogt contribuyó con nuevos vocabularios sobre los guayaquíes aunque ellos tenían los mismos problemas de autenticidad que señalamos aquí para otros casos, tal como lo señalara el botánico y antropólogo italiano radicado en Paraguay, Moisés Bertoni (1857-1929) (Bertoni 1939, citado en Pegoraro 2009: 131)

27 En este capítulo nos enfocamos en aquellas publicaciones vinculadas a la serie fotográfica de La Hitte y no realizamos una revisión exhaustiva de la bibliografía sobre los aché entre finales del siglo XIX y principios del sigloXX. Para ello sugerimos la consulta de Lehmann-Nitsche (1908) quien da una lista detallada de lo publicado sobre este tema desde mediados del siglo XVIII hasta 1908. 
volvemos a ver la misma imagen en un libro de texto español sobre los pueblos indígenas sudamericanos destinado a las escuelas (Navarro y Lamarca 1910). Finalmente, en una fecha tan tardía como 1950, otra vez esta misma foto vuelve a aparecer en un libro donde se relatan los viajes por el Chaco argentino y paraguayo del naturalista inglés Sir John Graham Kerr. En esta oportunidad es notable como se reproducen viejos preconceptos ya que en la leyenda que acompaña a la foto puede leerse "Un Indio Guayakí-uno de la raza de enanos que habita en las selvas en el interior de Paraguay" (Kerr 1950, Plate VII, mi traducción)

No conocemos con exactitud cuántas fueron las fotografías que la Hitte tomó al indígena capturado en Villa Encarnación. Sólo contamos como medida con la publicación que este último realizara junto con ten Kate en los Anales del Museo de La Plata en 1897 , donde se reproducen cinco fotografías de esa persona ${ }^{28}$. Cuatro de esas fotografías se imprimieron en conjunto (Ver Figura 5$)^{29}$, mientras que la quinta imagen, que lo muestra vistiendo un uniforme militar, descalzo, portando un fusil y acompañado por el Sr. Rodríguez, jefe político de Encarnación, se reprodujo en una plancha aparte junto con las fotografías de los niños aché y los cainguá estudiados en 1897. Esta fotografía, sin embargo y hasta donde sabemos, no fue reproducida en otros medios gráficos o científicos por lo que ahora solo nos ocuparemos en detalle de las cuatro imágenes de la plancha I, las cuales tuvieron un recorrido peculiar (Tabla 1).

\footnotetext{
${ }^{28}$ El único negativo de vidrio perteneciente a esta serie que se conserva en el Museo de La Plata presenta una inscripción que reza: "LH 10", que podría significar "La Hitte 10" lo que haría suponer que esa placa en formato $18 \times 24 \mathrm{~cm}$., perteneció alguna vez a una serie de al menos 10 imágenes.

${ }^{29}$ Aparece además en la plancha $X$ figura 3, junto al comandante de Villa Encarnación vestido con un uniforme militar. Sin embargo no hallamos esta fotografía reproducida ni duplicada por ningún otro medio.
} 
Tabla 1. Trayectoria de la serie fotográfica de 1894

\begin{tabular}{|c|c|c|c|c|c|c|c|c|c|}
\hline & 1895 & 1897 & 1898 & c. 1900 & 1902 & 1904(1) & $1904(2)$ & 1910 & 1950 \\
\hline & & $X$ & & & $X$ & & $X$ & & \\
\hline & $x$ & $X$ & X & & $X$ & & $X$ & & \\
\hline & $x$ & X & $x$ & $x$ & & $x$ & & $x$ & $x$ \\
\hline & & X & X & & & & & & \\
\hline & & & & & & & & & \\
\hline
\end{tabular}

Referencias: 1895: La Nación, miércoles 13 de febrero de 1895; 1897: Ten Kate y La Hitte (1897); 1898: Ehrenreich (1898); c. 1900: Tarjeta Postal Fotográfica, Librería Meyer; 1902: Vogt (1902); 1904(1): Giglioli (1904); 1904(2): Caras y Caretas, 1904; 1910: Navarro y Lamarca (1910); 1950: Kerr (1950).

Como puede observarse en la Tabla 1, si consideramos la trayectoria de todas las fotografías de la serie veremos que estas se reprodujeron en nueve oportunidades, en un período que va desde 1895 hasta 1950, en distintos formatos y soportes, sufriendo además distintas intervenciones (recortes, reencuadres, eliminación del fondo, coloreado, entre los más notables). Sin embargo, no todas esas fotografías fueron reproducidas y duplicadas por igual, algunas de ellas lo fueron en mayor medida que otras. La foto 4 fue la menos reproducida, apareció en ilustrando el artículo de Ehrenreich (1898: 75) aunque recortada, reencuadrada y con el fondo eliminado. La foto 1 apareció en la comunicación de Vogt (1902: 32), también recortada y reeencuadrada, y en la revista Caras y Caretas de 1904. La foto 2 fue una de las primeras en reproducirse ya que apreció en forma de litografía en la publicación de La 
Nación del 13 de febrero de 1895 (Figura 2), y también fue publicada por Ehrenreich (1898: 75) donde se recortó la figura y se eliminó el fondo (Figura 6) y en Vogt (1902: 32) donde la foto fue recortada y reencuadrada, conservándose el fondo y también se utilizó en la revista Caras y Caretas №304 del 30 de julio de 1904. Finalmente la foto 3 fue la fotografía más duplicada de toda la serie. Apareció en forma de litografía en la Nación de 1895 (Figura 2), fue coloreada e impresa en forma de tarjeta postal (Figura 3), se utilizó como ilustración en dos publicaciones científicas (Ehrenreich 1898, pp. 75 y Giglioli 1904), en el relato de John Graham Kerr (1950, Plate VII) y también en el manual escolar de Navarro y Lamarca (1910: 63). En esta sucesión de reproducciones esta fotografía fue litografiada, coloreada, recortada, reencuadrada, y se eliminó el fondo. Es además la única fotografía cuyo negativo se conserva en el Archivo Histórico y Fotográfico del Museo de La Plata, por ello nos parece importante ensayar un breve análisis de la misma.

En esta imagen, la más difundida entonces de las que La Hitte tomó al indígena Aché en $1894^{30}$, éste se encuentra vistiendo un bonete hecho con piel de felino y cola de caballo, un collar de dientes de pecarí rodea su cuello, y con su mano derecha sostiene un gran arco y una flecha. Su mirada esquiva la cámara, desviándose hacia la izquierda, como atento a otra cosa. A sus pies vemos una serie de elementos de procedencia -aparentemente- Aché, un hacha de piedra, un cuenco, una larga soga y otros objetos elaborados en hueso. Finalmente, como escenario de este retrato, se eligió la gran plaza de la antigua Misión Jesuítica de Trinidad, cuyas ruinas, sugestivamente, hacen de fondo. Como dijimos más arriba esta fotografía no fue tomada siguiendo las pautas de la fotografía antropológica de entonces, sino que a través de ella se buscó construir una imagen de los aché que diera cuenta tanto de sus rasgos físicos como de su cultural material. Una imagen cargada de exotismo, propia de la visión del indígena como buen salvaje, mediante la cual se buscaba generar en el espectador un efecto de realidad, en cuanto a una pertenencia y una identidad étnica. (Alvarado 2005: 5) Esta intención queda en evidencia si atendemos a las circunstancias

\footnotetext{
${ }^{30}$ El negativo de esta imagen aún se conserva en el Archivo Histórico y Fotográfico del Museo de La Plata. Se trata de una placa de vidrio, emulsionada con gelatino bromuro (placa seca) en formato 18 X 24 centímetros.
} 
previas a la toma de las fotografías. Cuando La Hitte llega al destacamento militar de Villa Encarnación, según el mismo nos narra, encuentra que el indígena, el mismo que en la fotografía aparece vistiendo las mejores ropas de su "tribu" y en actitud altiva, se hallaba en un rincón del cuartel vistiendo un calzoncillo y un viejo saco militar. Y si repasamos el relato de la expedición veremos que en una de las batidas militares, donde fueron muertos otros dos indígenas guayaquíes, se recolectaron varios objetos pertenecientes a ese pueblo, entre ellos el bonete de piel de felino y cola de caballo que aparece en las fotos.

Figura 7. Negativo de vidrio $18 \times 24 \mathrm{~cm}$., Charles de Lahitte, 1894. Este negativo es la única imagen de la serie que tomó La Hitte en Villa Encarnación en 1894 que se conserva en el Archivo Fotográfico del Museo de La Plata.

Todos estos elementos fueron puestos en juego a la hora de tomar las fotografías, y el indígena fue impulsado por el fotógrafo a colocarse las ropas, lucir los adornos y portar los objetos que supuestamente pertenecían a su grupo. En esta instancia se reafirma lo que Alvarado denomina "efecto de indiscernibilidad"31 de la vestimenta, ya que esta pasa a constituirse en señal inequívoca de pertenencia e identidad étnica

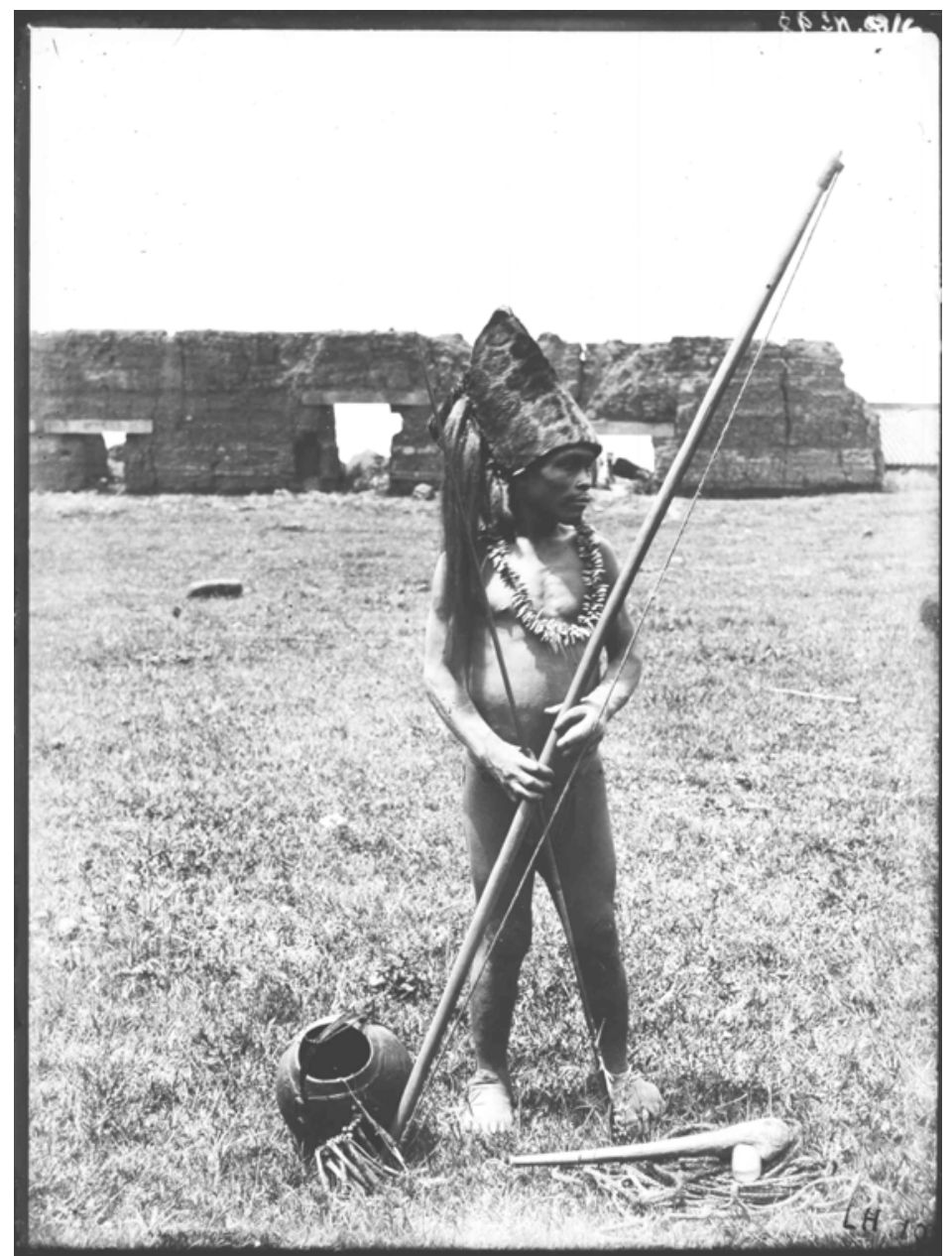

\footnotetext{
${ }^{31}$ De acuerdo al planteo de esta autora: "Vestirse y adornarse -es decir, usar un traje y lucir una indumentariaconsiste, fundamentalmente, en cubrirse, revestirse o ataviarse con una serie de artefactos y objetos de una materialidad que se adecua a una corporalidad, no sólo en el sentido de la forma, sino también en relación a una dinámica que implica gestos, ademanes y movimientos. Esta continuidad cuerpo-traje/indumentaria, esta imposibilidad de diferenciar claramente entre la corporalidad dada y la vestimenta producida, genera lo que denominaremos el "efecto de indiscernibilidad (...) Este efecto se fundamenta en una especie de "correspondencia" entre la individualidad del sujeto y su vestimenta. Así, al observar cualquier sujeto vestido, ataviado y adornado presentará, para nosotros, una mayor o menor "correspondencia" entre su particularidad como persona y su indumentaria." (Alvarado 2000:138)
} 
(Alvarado 2000:148), logrando así una verdadera "naturalización" del fotografiado, su transfiguración en el "buen salvaje". Sin embargo, la inclusión de las ruinas de la antigua misión jesuítica como fondo de esta imagen estaría yendo en contra de ese intento de naturalización haciendo intervenir una pista histórica en la imagen.

En definitiva, la serie fotográfica en su conjunto, puede entenderse como la construcción de una "escena étnica", una serie de retratos etnográficos, donde haciendo posar al retratado junto a una serie de artefactos que supuestamente pertenecen a su cultura, se busca lograr un efecto de realidad. Sin embargo al conocer la historia de estas fotografías, del fotógrafo y de quien allí aparece retratado, y poder identificar los dispositivos visuales que ese fotógrafo puso en juego, podemos visualizar esta imagen no como el registro objetivo de una realidad que alguna vez tuvo lugar sino más bien como una construcción que pone en evidencia la ideología de quien tomó la foto (Alvarado 2005), junto con la asimétrica relación de poder establecida entre fotógrafo y fotografiado, además de contribuir a los fines de autopromoción que pudo haber tenido La Hitte.

Aunque ten Kate había elogiado en su texto a las fotografías tomadas por La Hitte, no todos los antropólogos del momento coincidían con su apreciación. Guido Boggiani (1861-1901), que por ese entonces se encontraba viajando entre distintos pueblos indígenas del Chaco paraguayo y la región del Pantanal brasileño decía que las Notes Ethnographiques eran "muy pobre cosa", observando que "las reproducciones de fotografías y objetos no son a la altura de los medios de que evidentemente disponen los Talleres del Museo."32 En esa apreciación coincidía con su compatriota Enrico Giglioli, quien en su publicación de 1904 incluyó justamente una reproducción de esa fotografía, consideraba que esta no era "una buena imagen", a pesar de lo cual no perdía interés para el etnólogo "ya que retrata un nativo de Sudamérica todavía viviendo en la "Edad de Piedra" (Giglioli 1904:161, mi traducción). Queda claro aquí, como marcamos más arriba que a pesar de las críticas suscitadas en cuanto a la calidad de las imágenes obtenidas por La Hitte ellas seguían reproduciéndose debido a

\footnotetext{
${ }^{32}$ Carta de Guido Boggiani a Samuel Lafone Quevedo (AHFMLP)
} 
que fueron durante al menos una década, las únicas imágenes de los guayaquíes, privilegiándose de este modo el contenido por sobre la forma de la imagen, aunque se tratar de algo que, desde la actualidad, podría considerarse cercano a la falsificación. Por otra parte, estas discusiones en torno al valor de la fotografía nos brindan nuevos datos para discutir la tan repetida afirmación que hace énfasis en la confianza ciega que la sociedad del siglo XIX habría depositado en la capacidad de la fotografía para reproducir objetivamente la realidad, indicándonos que en la consideración de las imágenes intervenían otros elementos de juicio además de la objetividad. Volveremos sobre esta cuestión al final de este capítulo.

\section{Guido Boggiani, el Museo de La Plata y la colección de tipos indígenas de Sudamérica Central}

Guido Boggiani nació en Omegna, provincia de Novara, Italia, el 25 de setiembre de 1861, desde su juventud se formó en dibujo y pintura, llegando a estudiar en la Academia di Brera de Milán con el pintor Filippo Carcano (1840-1914) considerado el maestro del naturalismo lombardo (Bonati 2006: 125). Llegó a Buenos Aires a fines de 1887 trasladándose a Paraguay al año siguiente (Fricova 1997). Una vez allí Boggiani se dedicó al comercio de pieles de venado y de objetos de manufactura indígena, lo que lo llevó a entrar en contacto con diferentes pueblos indígenas que poblaban ambas márgenes del Alto Paraguay, entablando su contacto más estable con los Chamacoco (Ishir) del Chaco, y posteriormente con los Caduveo del Pantanal brasileño (Bonati 2006: 125). Si bien este contacto tuvo inicialmente fines comerciales, Boggiani pronto se dedicó no sólo a coleccionar objetos de interés etnográfico sino también datos lingüísticos sobre esos pueblos, indicando una vez más el vínculo indisoluble que existe entre la recolección de datos en el llamado espacio del "campo" y el desarrollo del comercio $^{33}$. Luego de cinco años de estadía en el Paraguay, en 1893, regresó a

\footnotetext{
${ }^{33}$ En la correspondencia entre Guido Boggiani y Samuel Lafone Quevedo encontramos constantes referencias del primero a las dificultades que sus actividades comerciales le traían a sus intereses etnográficos. Por ejemplo el 12 de julio de 1896, desde Puerto casado declaraba: "Las exigencias de mis trabajos comerciales me dejan poca libertad de movimiento y tengo que contentarme con lo que tengo a la mano en los alrededores". O desde Asunción el 29 de diciembre de 1897 "Estos malditos y desgraciados negocios me vuelven loco y estorban de una manera lastimosa mis estudios preferidos. ¿Cuándo acabará ese tormento?”.
} 
Italia donde dio conferencias (Boggiani 1894), publicó algunos trabajos ${ }^{34}$ y perfeccionó sus conocimientos etnográficos y antropológicos. Regresó a Sudamérica en 1896 trayendo consigo una cámara fotográfica que incorporó a sus viajes de campo ${ }^{35}$.

Para 1901, año en que emprendió la expedición al interior del Chaco paraguayo que le costaría la vida, la colección fotográfica de Boggiani contaba con más de 400 fotografías de distintos pueblos indígenas del Alto Paraguay. La ejecución técnica y calidad compositiva de las fotografía de Boggiani fue calificada no hace mucho como "una verdadera síntesis entre la sugestión estética de la imagen y el rigor descriptivo que lo volverían pionero de las actuales preocupaciones de la antropología visual." (Spadafora 2006: 120)

No nos vamos a detener aquí en los detalles biográficos de este pintor, fotógrafo y comerciante italiano que ya fueron tratados en distintas ocasiones (Scotti 1955; Viviani 1958; Diaz-Perez 1977; Leigheb 1986; Bonati 2006; entre otros) ni tampoco vamos a analizar en profundidad su obra fotográfica que, más recientemente, también fue objeto de varias publicaciones (Fricova 1997; AAVV 2002; Giordano 2004). Nos interesa referirnos a las relaciones que se establecieron entre Guido Boggiani y la dirección del Museo de La Plata en relación a la adquisición de las fotografías de pueblos indígenas chaqueños, haciendo especial hincapié en lo que sucedió con posterioridad a su muerte, en ocasión de editarse la "Colección Boggiani de Tipos Indígenas de Sudamérica Central" por el entonces jefe de la Sección Antropología del Museo de La Plata, Robert Lehmann-Nitsche.

\footnotetext{
34 Siendo el más importante de este período "I Caduvei (Mbyá o Guaycurú). Viaggi d'un artista nell'America Meridionales, con prefazione ed uno studio storico ed etnográfico del dottore G. A. Colini. Roma, 1895. (Pubblicato col concorso della Societá Geografica Italiana di Roma.)" y que, según Metraux, tuvo un éxito grande y merecido (Metraux 1930: 498).

${ }^{35}$ En su segundo viaje a tierras de los Caduveo, en 1897 Boggiani tenía como principal propósito "la compra de pieles de venado y algunas cosas de valor $y$, en segundo lugar el de ver algunas tierras muy alabadas como hermosísimas y aptas para establecer una fazenda." Buscando además "resolver el problema geográfico enunciado respecto del curso del río[Nabileque]; pasar otra vez un tiempo entre los Caduveos con fines etnológicos; obtener fotografías de tipos, cosas, y aspectos del país; recoger materiales sobre su arte ornamental y su lengua; adquirir objetos etnográficos; $y$, por último, recoger insectos para mi amigo Gestro del Museo Cívico de Historia Natural de Génova, para todo lo cual llevé papel, lápiz, plumas y tinta, una gran máquina fotográfico con 24 placas de $18 \times 24$ y 30 de 13 X 18, y varios tubos de alcohol" (Boggiani 1930: 504)
} 
Las relaciones entre Boggiani y algunos de los integrantes del personal del Museo de La Plata se remontan hasta aproximadamente mediados de la década de 1890, a partir de su segunda estadía en Sudamérica. Al menos desde 1896 Boggiani venía sosteniendo una relación epistolar y de de intercambio de datos, interpretaciones y bibliografía que se mantuvo al menos hasta 1900 con Samuel Lafone Quevedo (18351920), corresponsal del Museo de La Plata en la provincia de Catamarca ${ }^{36}$. Como queda evidenciado por la lectura de la correspondencia entre estos dos hombres, Boggiani, con la intermediación de Lafone buscaba llegar a Francisco Moreno con diversos propósitos como la publicación de alguno de sus trabajos, la venta de sus colecciones e incluso su contratación como personal de esa institución. En efecto durante el año de 1897 Boggiani buscó publicar un manuscrito sobre los pueblos Guaicurú ya sea en la Revista o en los Anales del Museo de La Plata lo que finalmente no sucedió ${ }^{37}$, debido posiblemente al nuevo foco que tomaron las publicaciones del museo a causa de la ocupación de su director en las tareas de delimitación de la frontera con Chile (Cfr. Farro 2009) ${ }^{38}$. Esto no desalentó a Boggiani quien para 1899 ofrecía en venta no solamente sus colecciones al Museo de La Plata, sino que además se ofrecía él mismo para organizarlas, clasificarlas y mantenerlas en calidad de encargado de la sección etnográfica del Museo $^{39}$. Esta tarea se volvía necesaria a criterio de Boggiani ya que "esa calamidad teutónica de Lehmann-Nitsche que se ocupa de descubrir lepra precolombina ${ }^{40}$ mientras está la sección etnográfica en el desorden que conocemos, no es ciertamente elemento que valga a levantar $y$ popularizar el Museo." 41

\footnotetext{
${ }^{36}$ Además de prestar apoyo logístico a las expediciones del Museo de La Plata en esa provincia Lafone había puesto al servicio de esa institución su red de relaciones en la región y además recolectaba material arqueológico que enviaba frecuentemente a esa institución (Cfr. Farro 2009)

${ }^{37}$ A diferencia de lo que ocurría con el Instituto Geográfico Argentino donde Boggiani publicaría tres artículos, dos en $1897 \mathrm{y}$ un tercero en 1899. A pesar de ello Boggiani hubiera preferido ver publicado alguno de sus trabajos por el Museo de La Plata ya que aquel Instituto no podía competir en calidad de edición con el Museo. Carta de Guido Boggiani a Samule Lafone Quevedo, Puerto 14 de Mayo, 18/05/1897. (AHFMLP)

${ }^{38}$ Este trabajo fue publicado finalmente por la Sociedad Geográfica Italiana (Boggiani 1898).

39 Carta de Guidgo Boggiani a Samuel Lafone Quevedo, Asunción, 11 de abril de 1899 (AHFMLP)

40 Lehmann-Nitsche (1899c)

${ }^{41}$ Carta de Guido Boggiani a Samuel Lafone Quevedo. Asunción, 26 de marzo de 1899 (AHFMLP) Por otra parte en carta enviado a Lehmann-Nitsche el 23 de mayo de 1900 Boggiani le agradecía por el envío de esa publicación (AHFMLP)
} 
Aunque Moreno no contrataría a Boggiani, este no desistiría en sus esfuerzos por conseguir algún financiamiento para sus expediciones por parte de aquella institución. En setiembre de 1900 anunciaba al propio Lehmann-Nitsche haber encontrado un sitio con varias sepulturas del pueblo aché (guayaquíes), de donde podría obtener "cuatro o cinco esqueletos completos". De esa forma Boggiani le estaba ofreciendo al museo, por adelantado, lo que obtuviera en esa expedición, solicitando se le asegurara una suma de "\$600 m/n (seiscientos nacionales) por cada esqueleto completo", ya que según el mismo hacía notar "no estoy en condiciones de meterme en una empresa tan costosa por el solo amor al arte",42.

Robert Lehmann-Nitsche y Guido Boggiani mantuvieron una relación epistolar y de intercambio bibliográfico al menos desde 1899. En este sentido Lehmann-Nitsche conoció las fotografías de Boggiani, cuando el italiano estuvo de paso por Buenos Aires, a principios de ese año.

"En esta oportunidad fue cuando Boggiani puso ante mi un cajón de madera, bien labrado, que abrió con cierta calma. Era una primicia. Me era dado admirar las hermosas placas originales (de 18 por 24 centímetros) que habían de servir para formar la hoy celebrada colección, fruto de una labor tan interesante como intensa. Quedé admirado y en espera del momento en que Boggiani pudiese publicar su obra para disfrutar con calma de aquel tesoro etnográfico-antropológico." (LehmannNitsche 1977:75-76)

Finalmente Boggiani vendió sus colecciones a los museos de Berlin, Stuttgart y Roma, aunque dejó gran parte de sus fotografías en Buenos Aires. Luego de su muerte estas fotografías fueron publicadas por Roberto Rosauer en forma de tarjetas postales editadas por Robert Lehmann-Nitsche, quien sostenía que de ese modo estaba cumpliendo la voluntad de Boggiani. En una de sus últimas estadías en Buenos Aires,

\footnotetext{
${ }^{42}$ Carta de Guido Boggiani a Robert Lehmann-Nitsche, Asunción 26 de setiembre de 1900. (Legado LehmannNitsche, IAI-Berlin) (subrayado en el original).
} 
en 1898, Boggiani había depositado parte de sus negativos en la Sociedad Fotográfica Argentina de Aficionados ${ }^{43}$, entregando la otra parte al Dr. Leopoldo Uriarte, también miembro de esta asociación para que los guardase con los restantes. De acuerdo a las anotaciones manuscritas de Boggiani en su catálogo, estos negativos llegaban para el 15 de setiembre de 1901 a un total de 415 fotografías (Fricová 1997). Una vez muerto Boggiani, según relata Lehmann-Nitsche, el depositario de sus placas fotograficas al no tener noticias del explorador, puso en venta copias de las placas que fueron adquiridas por el editor Rosauer. Este último se contactó con Lehmann-Nitsche quien le hizo notar el gran valor científico y artístico que tenían esas imágenes, señanalándole además que "sería un acto de justicia respetar la memoria del desgraciado explorador italiano, publicando íntegra aquella colección" (Lehmann-Nitsche1977 [1916]: 77) Boggiani le había confiado a Lehmann-Nitsche su intención de publicar estas imágenes en forma de atlas antropológico por lo que Lehmann-Nitsche declaraba que estaba cumpliendo el deseo del italiano de publicarlas como complemento iconográfico a sus trabajos anteriores en los Anales del Museo de La Plata (Lehmann-Nitsche 1904). De esa forma, en 1904 Roberto Rosauer publicó 114 postales de indígenas del Gran Chaco hechas a partir de las fotografías de Boggiani más un retrato del fallecido etnógrafo, que fueron seleccionadas por Robert Lehmann-Nitsche.

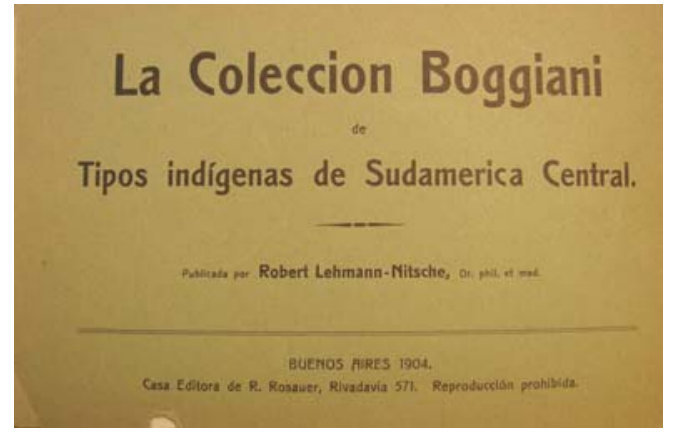

Figura 9. Tapa de la Colección Boggiani (Legado Robert LehmannNitsche, IAI, Berlin)

La intervención de Lehmann-Nitsche sobre esta colección quedó evidenciada en los distintos criterios que adoptó para ordenar estas láminas. En primer lugar, ellas fueron divididas físicamente en dos grandes grupos. El primero reunía 100 imágenes de indígenas más la postal con el retrato de Boggiani conformando lo que podemos llamar

\footnotetext{
${ }^{43}$ La Sociedad Fotográfica Argentina de Aficionados fue fundada en Buenos en 1899 por Francisco Ayerza y Leonardo Pereyra, llegó a tener más de 600 socios y funcionó hasta el año 1926. Algunos autores han señalado que esta sociedad tuvo un papel destacado como proveedora de imágenes a la prensa, lo que de hecho la convirtió en "la primera agencia fotográfica del país" (Alexander y Cuarterolo 2003)
} 
la colección principal. El segundo grupo, o suplemento como lo denominó LehmannNitsche, estaba formado por 14 imágenes que representaban cuerpos también de indígenas pero completamente desnudos. Este suplemento no estaba dirigido al gran público de Buenos Aires, sino que había sido destinado al "mundo científico"44. Por ese motivo este último grupo fue reunido en un anexo separado de la colección principal que, como veremos, circuló por canales diferentes al grupo mayoritario.

Esta división física de las láminas marcaba en cierta forma un límite entre dos espacios por los cuales circulaban las imágenes fotográficas sobre pueblos indígenas. Uno de estos espacios era el mercado de las tarjetas postales que, como señalamos al principio de este capítulo, se encontraba para fines del siglo XIX y principios del siglo $X X$ en pleno auge y expansión. En este espacio las fotografías eran seleccionadas y presentadas teniendo en cuenta la aceptación o el rechazo que estas pudieran suscitar entre el gran público ${ }^{45}$. Desplazadas al suplemento quedaban aquellas imágenes que se consideraban que tenían valor solamente para los científicos, imágenes pertenecientes al espacio más restringido de la antropología, más reducidas en número y que se consideraba podían tener más valor para los estudios antropológicos y que se consideraba podían tener más valor para los estudios antropológicos pero que el mundo del comercio también podía hacer accesible a cualquiera. Como demuestra el mismo destino de las fotos de Boggiani y sus empeños por vender sus colecciones, ciencia y comercio no pertenecen a universos tan diversos como Lehmann-Nitsche pretendía afirmar.

Sirviéndose de las anotaciones originales de Boggiani, Lehmann-Nitsche ordenó tanto la colección principal como el suplemento ${ }^{46}$ en grupos cada vez menos inclusivos. De este modo, utilizando un criterio lingüísitico las postales se dividieron en tres grandes conjuntos: "Grupo Mascoi", "Grupo Guaicurú" y "Grupos aislados"; dentro de cada uno

\footnotetext{
44 "Por el carácter de estas fotografías no era posible publicarlas en una serie no menos destinada para el gran público que para el mundo científico" (Lehmann-Nitsche 1904c)

${ }^{45}$ Esto llevaba a que en varias oportunidades, como vimos más arriba en el caso de la postal del indígena aché, adjuntaran a las postales leyendas falsas o inexactas.

46 "El índice representa el catálogo original sin alteración alguna, con excepción del orden de las láminas." (Lehamnn-Nitsche 1904d)
} 
de estos grupos las imágenes se agrupaban de acuerdo a la pertenencia étnica de las personas retratadas (Sanapaná, Angaité, Lengua, Toba, etc.); estas a su vez fueron ordenadas de acuerdo al sexo (primero los hombres y luego las mujeres) y la edad (de menores a mayores). En los casos en que hubiese más de un retrato de la misma persona estos se ordenaron siguiendo un criterio "fotográfico", es decir, de acuerdo al encuadre de cada imagen, de la siguiente manera: primero las de cuerpo entero, luego las de torso y dentro de cada una de estas categorías ubicó primero las de frente y luego las de perfil. El índice contenía además de estos datos una breve descripción del contenido de la lámina. El lugar donde se tomó la fotografía y el nombre de los retratados (Lehmann-Nitsche 1904d). (Figura 10)

Figura 10. Primera página del índice de la colección Boggiani (sección principal). Pueden verse los distintos criterios de ordenamiento utilizados.

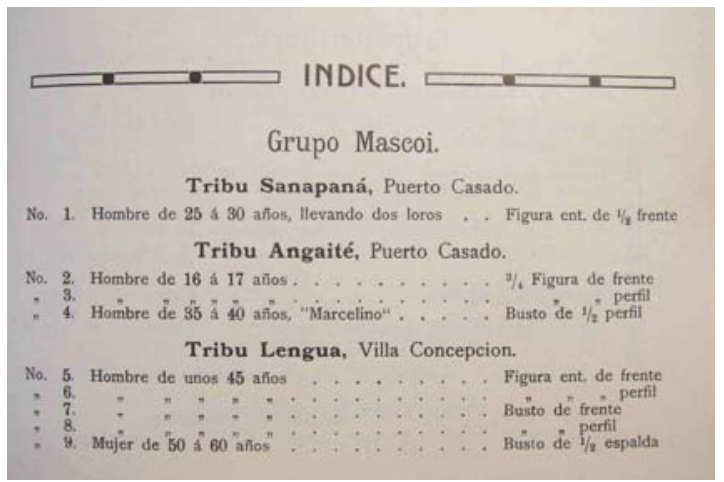

Los pueblos indígenas representados en la colección son: Sanapaná, 1 postal; Angaité, 3 postales; Lengua, 5 postales; pertenecientes al "Grupo Mascoi". Caduveo (Mbayá), 15 postales; Toba, 1 postal; Payagua, 6 postales; pertenecientes "Grupo Guaicurú". Finalmente, entre los "Grupos aislados" incluyó 4 postales de Bororó y 79 postales Chamacoco, siendo este el pueblo indígena más representado de la colección con algo más de 2/3 de las imágenes.

El formato en que fueron publicadas estas postales fue también elección de LehmannNitsche, quien se decidió por el formato pequeño en octavas cuando podría haber optado por un formato mayor, al menos en cuartas y con bordes blancos que permitiera manipular y comparar las imágenes con mayor facilidad. Sin embargo, según sostenía él mismo, 
"el formato pequeño permitiría, por ejemplo, poner las postales bajo un vidrio enmarcado y utilizarlas para la enseñanza y exhibición pública sin ocupar demasiado espacio, lo que posibilita un arreglo muy sencillo y si se arreglan en continuidad en un espacio mayor puede ser observadas confortablemente y sintetizadas, resumidas, sumarizadas. De modo tal que con una sola mirada puedan capturarse los rasgos característicos comunes y diferencias sin cansarse" (Lehmann-Nitsche 1904d: 83, mi traducción).

El mismo año de 1904 Lehmann-Nitsche estaría publicando en la revista del Museo de La Plata el estudio antropológico realizado sobre los toba takshik que habían sido traídos a Buenos Aires, allí utiliza para ordenar las fotografías un criterio similar a éste, en el sentido que pretende que la disposición de las imágenes permita, golpe de vista mediante, tener una impresión general del "tipo" de esa "raza". Volveremos sobre este punto en el capítulo siguiente.

Una reseña realizada al momento de lanzarse esta colección la consideraba como "un álbum muy valioso para el etnólogo con una forma fácilmente utilizable, cubriendo una considerable variedad de vida y actividad indígena, y es un complemento bienvenido a los datos visuales de la tribus indias distantes" (Chamberlain 1905:326, mi traducción)

Figura 11. "Indio Chamacoco "Wéddi", Puerto 14 de Mayo. Colección Boggiani, publ. por Dr. R. Lehmann-Nitsche, $N^{\circ}$ 38. 2038 Editor R. Rosauer, Rivadavia 571, Buenos Aires."

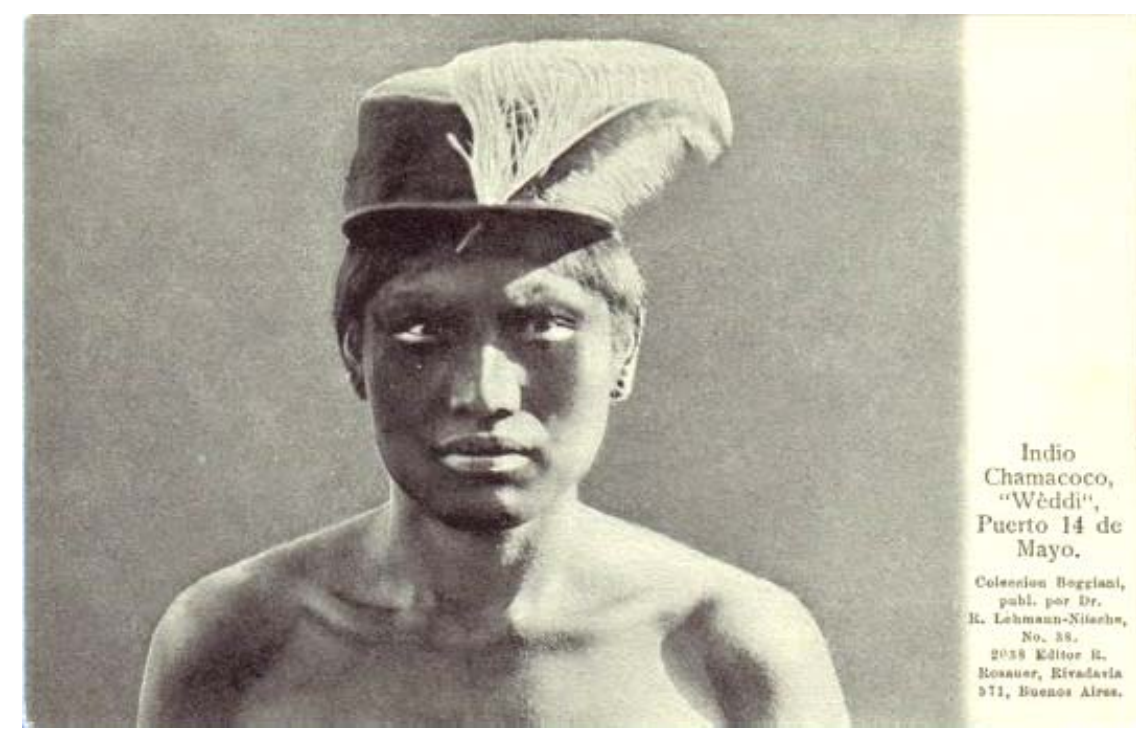


La colección Boggiani fue reeditada por la misma editorial Rosauer, aunque también una selección de algunas de esas imágenes fue comercializada por parte de otro editor de postales de Buenos Aires, Zaverio Fumagalli. Este editor, al igual que como vimos en el caso de los guayaquíes, adulteró la pertenencia geográfica de las postales agregándoles en la descripción la leyenda "República Argentina", con un fin claramente comercial (Giordano 2004). Para esta autora estas reediciones estarían probando la buena recepción que tuvo la colección por parte del público porteño. Sin embargo, durante la década de 1910 la demanda parecía haber disminuido notablemente. En 1914 la Librería Alemana-Sudamericana de Carlos Balzer en Buenos Aires comunicaba a Robert Lehmann-Nitsche que ellos aún contaban con 40 ejemplares completos de esta colección, que estaban dispuestos a vender al Museo de La Plata al módico precio de $\$ 6$ cada uno ${ }^{47}$.

Pero no sólo la baja en la demanda preocupaba a los editores de estas postales, ya que al poco tiempo de salir a la venta se vieron involucrados en un interesante litigio sobre la propiedad intelectual de esa colección. En efecto, la publicación de esta serie de fotografías provocó una "agria disputa" (Bilbao 2002:) entre Lehmann-Nitsche y el explorador checoslovaco Albert Vojtech Fric quien se había convertido en administrador de la "herencia científica" de Guido Boggiani.

\section{La muerte de Boggiani y las disputas entre sus albaceas.}

El 24 de octubre de 1901 Boggiani emprendería desde la estancia "Los Médanos", en las cercanías de Puerto Casado, la que fue su última expedición, internándose en el Chaco paraguayo, en tierras que si bien pertenecían ancestralmente a los Chamacoco habían sido adquiridas en 1886, mediante subasta pública, por Carlos Casado del Alisal (1833-1899), importante empresario de origen español que también tenían negocios en Argentina. Precisamente en una carta dirigida a José Casado Sastre, hijo de Carlos Casado y administrador de sus propiedades en el Alto Paraguay, Boggiani se

47 Carta de Carlos Balzer a Robert Lehmann-Nitsche, Buenos Aires 18 de agosto de 1914. (Legado Robert Lehmann-Nitsche, IAI, Berlin, N-0070 b 1089,) 
alegra de que este último haya aceptado su proyecto de expedición, cuyo propósito era:

" $1^{\circ}$ Ver parajes nuevos no vistos por otros hasta ahora.- $2^{\circ}$ Sacar vistas del lugar cuanto más pintorescas posibles y típicos [SIC] del Chaco.- $3^{\circ}$ conocer mas intimamente a esta fracción Chamacoco de los Tumaná en sus costumbres, idiomas, etc.- $Y$ si algo más útil y practico se ofreciera (Como oro, diamantes, esmeraldas $y$ perlas engastonadas y libras esterlinas tanto mejor - A mas de esto el descubrimiento de campos lindos y parajes favorables para ganadería y agricultura y pintorescos para los demás no será casos indiferentes para mi (...) lo principal es conocer un pedazo mas de la topografía de sus propiedades, y encontrar campos buenos con buenos y abundantes pastos y aguadas para la hacienda." 48

En esta carta vemos como Boggiani conjugaba sus propios intereses con los intereses económicos de la familia Casado logrando de ese modo financiar su expedición, especulando incluso con la posibilidad de encontrar riquezas hasta ese momento desconocidas. En ese sentido iba preparado para realizar tomas fotográficas estereoscópicas además de una serie de mensuras y observaciones topográficas ${ }^{49}$. El personal de su expedición estaba compuesto por el cacique guaná Michí, su asistente paraguayo Félix Gavilán, un guía chamacoco llamado Cesareo "y tres chamacocos más quienes todos hablan brasilero con facilidad". 50

\footnotetext{
${ }^{48}$ Carta de Guido Boggiani a José Casado Sastre, Los Médanos el 7 de setiembre de 1901 (Manuel Gondra Manuscript Collection, Benson Latin American Collection, The University of Texas at Austin, Part V, Item N 1985) (copia mecanografiada) (subrayado en el original).

49 "Me propongo llevar el aparato estereoscópico con tres docenas de placas; la brújula con su trípode y el anteojo Si Ud. tiene allí el aparatito que se aplica en la pierna para contar los pasos, también lo llevaré pues esto de contar los pasos dá unos resultados espléndidos para cálculos de distancias." (Carta de Guido Boggiani a José Casado Sastre, Los Médanos el 7 de setiembre de 1901 - Manuel Gondra Manuscript Collection, Part V, Item N 1985, Benson Latin American Collection, The University of Texas at Austin,)

${ }^{50}$ Carta de Guido Boggiani a José Casado Sastre, Los Médanos Octubre 23 de 1901 (Manuel Gondra Manuscript Collection, Benson Latin American Collection, The University of Texas at Austin, Part V, Item N 1985)
} 
Figura 12. "La muerte del explorador Boggiani". Caras y Caretas, $N^{\circ} 272,9 / 12 / 1902$. La leyenda de la fotografía superior dice: "Luciano. Indio Chamacoco. Presunto matador de Boggiani", la leyenda de la fotografía inferior dice: "El Sr. Cancio y sus compañeros de expedición que fueron en busca de Boggianni"

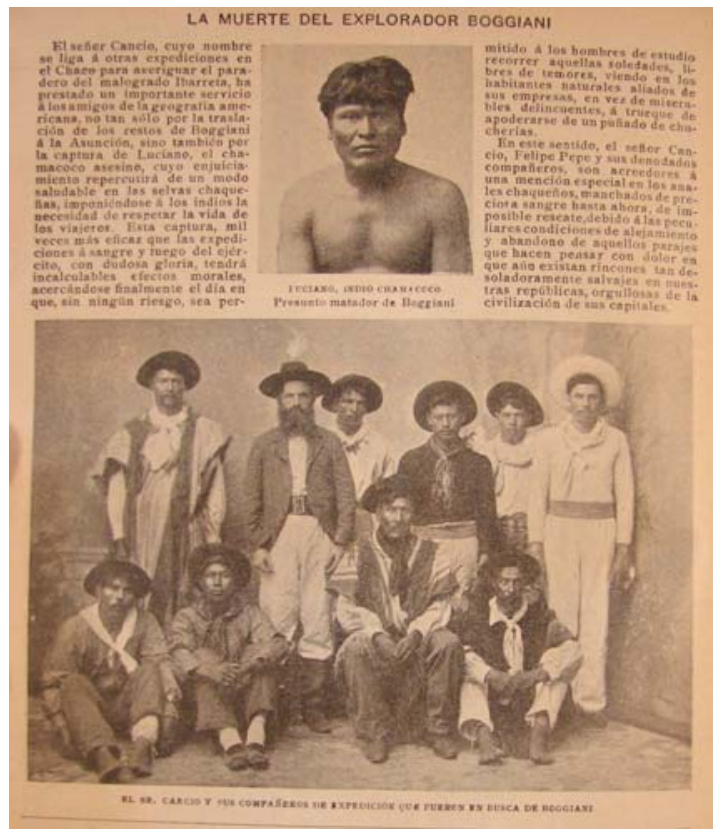

Las últimas noticias de Boggiani son del 31 de octubre de 1901 cuando le escribe una carta a Helmuth Gartner, capataz de la estancia Los Médanos ${ }^{51}$. Luego de esto no se supo más de él. La colectividad italiana de Asunción organizó una expedición de rescate al mando del español José Fernández Cancio (1870-1959), que el 20 de octubre de 1902 encontró su cadáver y el de su peón, Félix Gavilán, con la cabeza separada del cuerpo y los cráneos astillados (Spadafora 2006:120). La comunidad antropológica mundial se vio conmovida ante la noticia de la muerte del explorador italiano. Las primeras informaciones culpaban a los indígenas Toba (Qom) por este hecho, quienes ya habían sido señalados como los causantes de la muerte de otros exploradores del Chaco como el francés Jules Creveaux (1847-1882), y el español Pedro Enrique Ibarreta (1859-1898) algunos años antes ${ }^{52}$. La expedición de Fernández Cancio -quien poco antes había hallado los restos de Ibarreta-, señaló sin embargo a una parcialidad Chamacoco (Ishir) ${ }^{53}$ como los autores de su muerte, a la vez que

\footnotetext{
${ }^{51}$ Manuel Gondra Manuscript Collection, Benson Latin American Collection, The University of Texas at Austin, Part $\mathrm{V}$, Item $\mathrm{N}^{\circ} 1985$

${ }^{52}$ Cuando aún la expedición al mando de Fernández Cancio no había partido en busca de Boggiani el diario norteamericano The New York Times, afirmaba que toda su expedición había sido destruida, "presumiblemente por los feroces, prácticamente desconocidos Indios Tobas". (The New York Times, julio 27 de 1902, mi traducción).

${ }^{53}$ Boggiani de hecho tenía planeado visitar a los Tumaná, también conocidos como Chamacoco bravos
} 
recogió el testimonio de un indígena sobre las causas y circunstancias en que ella se produjo (Fernández Cancio 1903) ${ }^{54}$.

Lehmann-Nitsche, reproduciendo en la revista alemana Globus las noticias sobre la muerte de Boggiani que había publicado el diario porteño "La Prensa" el 28 de noviembre de 1902, señala que si bien su colección de objetos etnológicos habían sido adquirida por el Museo Real de Berlin (Museo Etnológico), Boggiani deseaba publicar parte de su colección fotográfica de tipos indígenas en los Anales del Museo de la Plata $^{55}$, este proyecto quedó trunco a causa de su muerte. Afortunadamente, señalaba Lehmann-Nitsche, esas fotografías se encontraban en buen cuidado y podían "ser salvadas para la ciencia" (Lehmann-Nitsche 1903: 82).
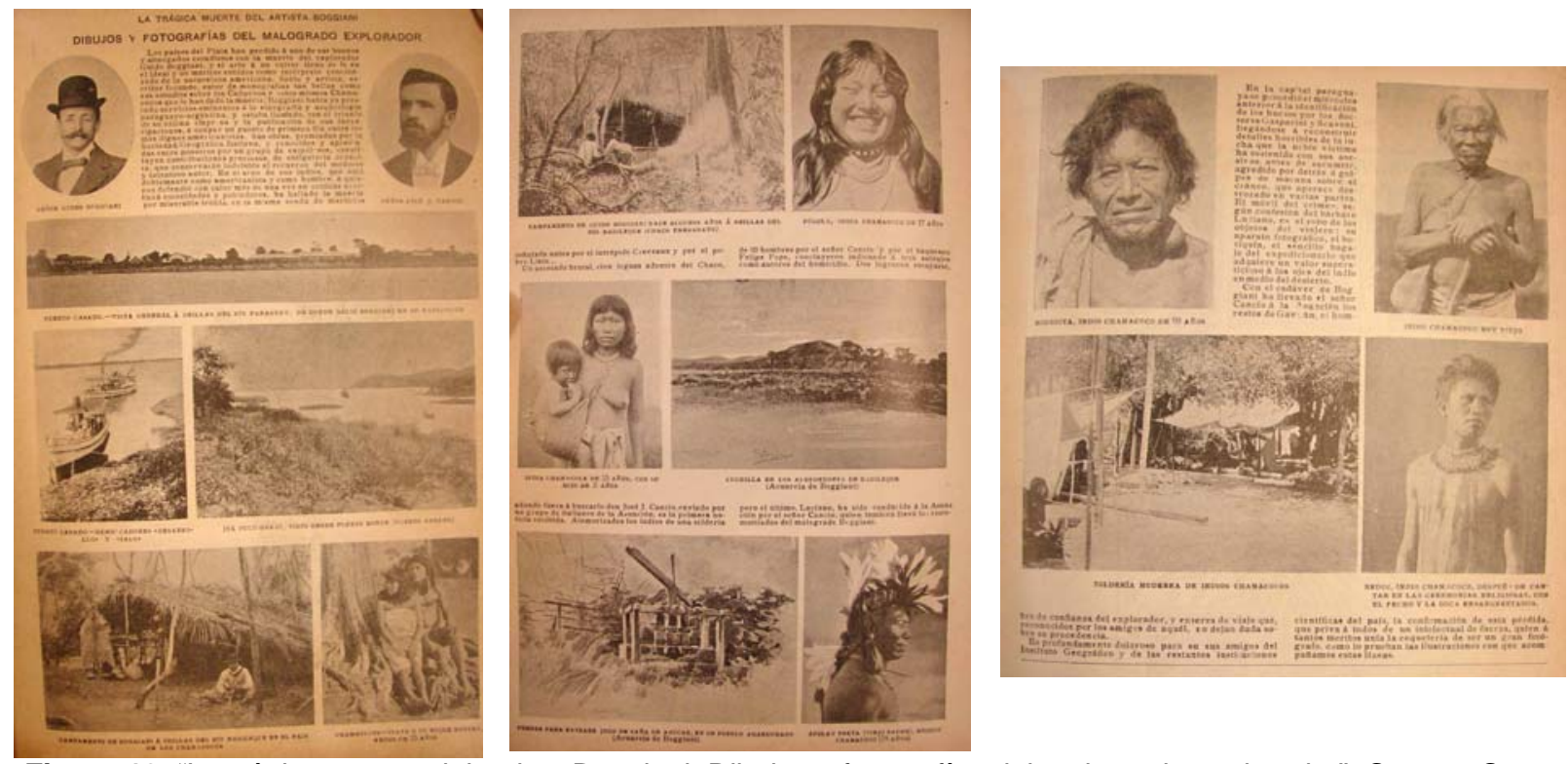

Figura 13. "La trágica muerte del artista Boggiani. Dibujos y fotografías del malogrado explorador", Caras y Caretas $N^{\circ} 271,29 / 11 / 1902$.

Recordemos que la expedición Fernández Cancio había descubierto el cuerpo de Boggiani en el interior del Chaco paraguayo cerca del 20 de octubre de 1902, tras lo cual, según manifiesta Lehamnn-Nitsche, el depositario de las fotografías de Boggiani, había decidido, hacer copias de sus fotografías y ponerlas a la venta. Al parecer esto

\footnotetext{
${ }^{54}$ No nos vamos a detener aquí en la descripción y análisis de las circunstancias de su muerte, para lo cual remitimos al original trabajo de Richard (2006)

${ }^{55}$ "Comprendo perfectamente la ventaja que yo tendría en ver publicada mi colección fotográfica de tipos indígenas, $y$ en ninguna parte mejor que en los Anales del Museo de La Plata" carta de Boggiani a Lehmann Nitsche, Asunción, 18 de julio de 1899 (Lehmann-Nitsche 1977: 76)
} 
ocurrió casi inmediatamente después de confirmarse aquel hecho. El 29 de noviembre del mismo año, en Buenos Aires, la revista Caras y Caretas publicaba un informe de tres páginas sobre la muerte de Boggiani, profusamente ilustrado con dibujos y fotografías del fallecido explorador (Figura 13). Algunas de estas fotografías formaron parte de la colección publicada en forma de tarjeta postal dos años después a instancias de Lehmann-Nitsche quien, había convencido al editor Rosauer de la necesidad de publicar estas imágenes dado "su valor científico y artístico" (Figura 13).

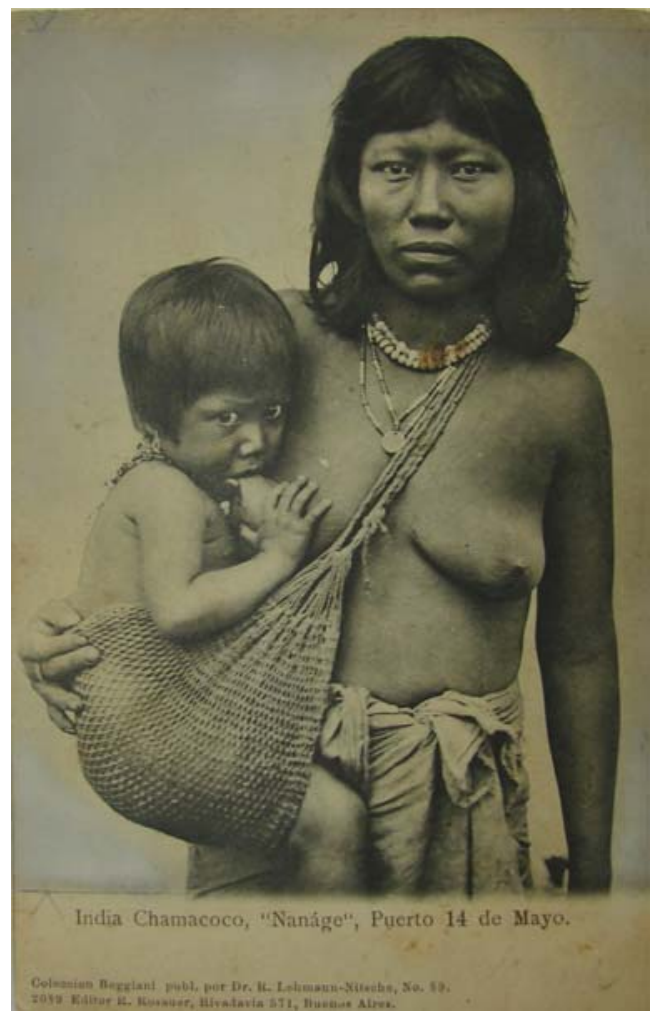

Figura 14. "India Chamacoco, "Nanáge", Puerto 14 de Mayo." (Colección Boggiani) (Tarjeta postal, Museo Etnográfico Andrés Barbero, Asunción, Paraguay) Esta fotografía también fue publicada en la revista Caras y Caretas del 29/11/1902, con la leyenda "India Chamacoca de 25 años, con su hijo de 2 años” (Cfr. Figura 13).

Entre la correspondencia de Roberto Lehmann Nitsche que se conserva en el Instituto Iberoamericano de Berlin pueden encontrarse varios indicios de las distintas donaciones que este último realizó de la colección Boggiani, que fue ofrecida al entonces rey de Italia ${ }^{56}$, al Museo Nacional de Copenhague ${ }^{57}$, a la Sociedad Geográfica de Roma ${ }^{58}$, al Museo Göldi de Pará (Brasil) ${ }^{59}$, (Museo Paranaense de Historia Natural y Etnografía). En otras ocasiones la colección era enviada ante el pedido expreso de los

\footnotetext{
${ }_{57}^{56}$ Legado Robert Lehmann-Nitsche, IAI, Berlin. N-0070 b 1089.

57 Idem ant.

58 Idem ant.

59 Idem ant.
} 
interesados, como en los casos de los antropólogos Eric Boman (1867-1924) ${ }^{60}$, Arthur Chervin (1850-1921) ${ }^{61}$, o Hermann ten Kate (1859-1931) ${ }^{62}$, entre otros.

La circulación a nivel mundial que tuvo la colección Boggiani nos muestra el constante y significativo flujo de imágenes que tuvo lugar a través de las redes de intercambio establecidas entre los académicos y otros interesados, en el siglo XIX y temprano siglo $X X$. En este sentido, las numerosas donaciones que realizara de esta colección le valió a Lehmann-Nitsche el reconocimiento de sus pares. Así es que la Sociedad Antropológica de Roma lo nombró "Socio corresponsal", a partir de su trabajo como editor (Lehmann-Nitsche 1977:78). Sin embargo Lehmann-Nitsche declaraba, años después (1916), que todo el trabajo realizado con la colección Boggiani -a la cual había accedido sin obtener o adquirir los derechos necesarios- había sido hecho con la intención de contribuir "a la fama del malogrado artista y viajero", aquel mismo que lo calificara de "calamidad teutónica". Así, al colocar en cada tarjeta postal un título con la leyenda "Colección Guido Boggiani", él creía "haber procedido como buen albacea, al hacerme cargo, inesperadamente, de aquellos bienes perdidos para el finado, bienes que estaban expuestos al peligro de ser aprovechados por cualquier ignorante sin que nadie jamás hubiese adivinado que eran la labor artística y científica del infortunado pintor y etnógrafo italiano." (Lehmann-Nitsche 1977:78) Estas últimas palabras traen a cuento un interesante conflicto que se desató justamente en torno a la propiedad de las fotografías de Boggiani luego de la edición realizada por Lehmann-Nitsche y publicada por Rosauer.

En octubre de 1904, al mismo tiempo que en Buenos Aires se editaba esta colección, el explorador checo Alberto Vojtech Fric (1882-1944) recibía de manos de Miguel Azevedo, ex-socio comercial de Boggiani, un conjunto de diarios ilustrados, anotaciones lingüísticas y copias de la correspondencia perteneciente a este último (Fricova 1997: 142). Seguidamente, en marzo de 1905 enterado de que los Chamacoco tenían en su poder algunos objetos que habían pertenecido a Boggiani, se

\footnotetext{
60 Idem ant.

61 Idem ant.

62 Idem ant.
} 
adentró en el Chaco paraguayo en busca de alguna información sobre su muerte. Una vez regresado a Europa en 1905 Fric se puso en contacto con Olivier Boggiani, hermano de Guido informádole lo que había sucedido en América con su hermano y los materiales que allí dejara (Fricova 1997: 146). A partir de allí Fric hizo las veces de representante de la familia Boggiani por lo que se lo iría a retribuir con el $60 \%$ de la suma que lograse obtener por los terrenos que el italiano había adquirido en la Patagonia, además de dejar a su plena disposición los negativos fotográficos que había recuperado ${ }^{63}$. Así, Fric se "indignó enormemente" cuando se enteró que la colección fotográfica de Boggiani había sido publicada en Buenos Aires sin consentimiento de sus herederos. A causa de lo cual se inició en marzo de 1906, una demanda judicial en nombre de la familia Boggiani contra el Museo de La Plata, Roberto Lehmann-Nitsche, y la sociedad Fotográfica Argentina de Aficionados donde se solicitaba una indemnización de 40.000 liras. (Fricova 1997: 147-149)

No tenemos información acerca de cómo se resolvió ese conflicto judicial, sin embargo es posible que la colección Boggiani pueda haber sido retirada de las ventas debido a ello. Como señala Bilbao, el silencio pudo haber sido una respuesta a esta demanda, que Ilevó a Lehamann-Nitsche a excluir de su lista bibliográfica dos publicaciones relacionadas con ese litigio. En la biobibliografía de ese autor realizada por José Torre Revello (1944-45), considerada una de las más completas y que además fue realizada con la colaboración de Juliane Dillenius, viuda de Lehmann-Nitsche, se excluyeron las noticias sobre la muerte de Boggiani que Lehmann-Nitsche publico en Globus en 1903 (Lehmann-NItsche 1903) además de la misma colección Boggiani publicada por Rosauer en 1904 (Lehmann-Nitsche 1904; Bilbao 2004: 98).

Según este autor es posible que haya ocurrido un arreglo extrajudicial entre LehmannNitsche y Fric donde el primero se habría comprometido a borrar los rastros que lo

\footnotetext{
${ }^{63}$ Estando Metraux de visita en casa el señor Fric nos cuenta que Dice Metraux "he visto en la casa del señor Fric, en Praga, una espléndida colección de fotografías y placas que pertenecieron a Boggiani. El señor Fric me aseguró que eran inéditas, pero pedía por ellas un precio fuera de mi alcance." (Metraux 1930:499) Durante 2002 el Museo "Isaac Fernández Blanco" de Buenos Aires expuso parte de su material fotográfico. Esa muestra fue curada por Yvanna Fricova y Pavel Fric, descendientes de Alberto Vojtech Fric.
} 
relacionaran con la colección Boggiani o tal vez solamente retirarse del asunto en forma displicente ${ }^{64}$ (Bilbao 2004: 98). Esto puede ser también la causa de la completa ausencia de la correspondencia, tanto en el Instituto Iberoamericano de Berlin como en el Museo de La Plata, que, como podemos suponer, podría haber existido entre Lehmann-Nitsche y Roberto Rosauer y que debería haber tenido como objeto la preparación de la edición de las fotografías de Boggiani ${ }^{65}$. En este sentido nos parece pertinente citar las palabras de Santiago Bilbao quien decía que los albaceas suelen ser "más celosos de los legados incluso que los herederos, hasta llegar a no divulgar la obra a su resguardo por diversos motivos. En este caso, los hechos demostrarían que otros se encargaron de lo que el albacea no quiso o no pudo hacer." (Bilbao 2004: 100)

Finalmente y pensando tanto en el caso de la postal de los guayaquíes como las postales editadas por Lehmman-Nitsche nos muestran que las fronteras entre lo comercial y lo académico y a su vez entre lo amateur y lo profesional que a fines del siglo XIX y principios del siglo XX eran difusas y poco reconocibles en tanto existía entre ellas una permeabilidad de la que dan cuenta los casos aquí estudiados. Tanto desde el lado de los fotógrafos comerciales las imágenes obtenidas por viajeros y antropólogos eran posibles de ser comercializadas como así también las imágenes obtenidas por aficionados y fotógrafos comerciales se juzgaban como de interés para la antropología.

\section{Fotografía, objeto de intercambio y evidencia científica}

A mediados del siglo XIX la fotografía surgió como una técnica que durante todo ese siglo y buena parte del siglo $\mathrm{XX}$, fue considerada por muchos como prueba de verdad, capaz de ofrecer un registro fidedigno de la realidad. Tal como señala Dubois (1986), la fotografía estuvo acompañada desde su surgimiento por un "séquito impresionante de discursos", entre los cuales "el discurso de la mímesis" ocuparía un lugar

\footnotetext{
${ }^{64}$ Aunque no es posible afirmar esta última posibilidad ya que Lehmann-Nitsche colaboró con un artículo sobre Boggiani en 1916, diez años después de iniciada la demanda judicial, a contribuir en una publicación coordinada por el escritor y cronista español, radicado en Paraguay, Viriato Diaz-Perez (1875-1958).(Diaz-Perez 1977)

${ }^{65}$ En este sentido también debemos hacer notar que ni en la Bilbioteca ni en el Archivo Histórico y Fotográfico del Museo de La Plata no se conserva ningún ejemplar de esa colección.
} 
preponderante. Esta "objetividad" adjudicada al procedimiento fotográfico venía dada, según se argumentaba, por su aparente carácter "natural", al ser el resultado de la acción de la luz sobre los granos de plata que era fijada sobre una placa o papel sensible, una reacción química propiciada por un dispositivo óptico-mecánico donde la mano del hombre no intervenía. La foto era concebida libre de los vicios propios de otras herramientas de registro anteriores -sobre todo el dibujo y la pintura- y considerada como espejo del mundo.

A medida que se fueron perfeccionando técnica e instrumentos, las aplicaciones de la fotografía a la ciencia empezaron a ser mayores y más variadas, proporcionando así un medio para la construcción de la evidencia, reemplazando al dibujo al momento de guardar un registro y como documento de valor científico que, por ejemplo, facilitó el intercambio de información. Como ha señalado Elizabeth Edwards (2001) y como vimos especialmente en la segunda parte de este capítulo mediante el ejemplo de la edición y posterior difusión de la colección Boggiani por parte de Robert LehmannNitsche, las fotografías, en tanto soporte material de datos en bruto, participaban en un esquema de reciprocidad actuando como un vehículo de comunicación entre los estudiosos y los distintos círculos de individuos dedicados a la antropología, quienes las coleccionaban para formar acervos que permitían posteriormente la realización de estudios raciales comparativos a escala global. En ese sentido vemos que estos dos roles de las fotografías, como evidencia científica y como objeto de intercambio pueden entenderse como dos cara de una misma moneda.

Por otro lado, tal como vimos aquí, hacia finales del siglo XIX y principios del siglo XX las fronteras entre la fotografía "comercial" y la fotografía "científica" no eran fija ni mucho menos infranqueables, sobre todo para el caso de las fotografías de pueblos indígenas las cuales podían pasar de las vitrinas de las casas fotográficas a su edición en publicaciones científicas especializadas, pasando por diarios y revistas, sin demasiados preámbulos, simplemente al ser consideradas "de interés" para el estudio de las "razas primitivas". En este sentido y a pesar del dudoso valor que, por ejemplo, las fotografías de los guayaquíes tuvieron para algunos antropólogos ellas 
acompañaron, en tanto evidencia, una discusión académica a escala internacional sobre el origen y posición en la "escala evolutiva" de ese pueblo. De modo que esas imágenes resultaron un buen caso para indagar en las posturas de la comunidad antropológica de finales del siglo XIX y principios del siglo XX con respecto al problema de la fotografía y su constitución en evidencia antropológica.

No obstante haberse establecido su valor científico, las fotos de La Hitte dejaban que desear en términos estéticos y, como vimos, también como evidencia. A pesar de que ten Kate las calificó de "belles photographies" otros no estaban tan de acuerdo. Guido Boggiani, en carta a Samuel Lafone Quevedo criticaba como ya marcamos la mala calidad de las imágenes de La Hitte y se lamentaba de que "no se sepa salir de esa rutina de mal gusto" ${ }^{66}$, y aunque esta crítica puede haber sido motivada en parte por el deseo de Boggiani de formar parte del personal científico estable del Museo de La Plata, pudimos encontrar otros juicios de su parte referidos a la utilización de la fotografía en las publicaciones antropológicas, que iban en ese mismo sentido. Cuando, por ejemplo pudo descubrir que las fotografías de indígenas del Chaco publicadas por un botánico sueco que había estado en Paraguay (Lindman 1899) no brindaban el nombre del fotógrafo que las había obtenido dejando creer que había sido el propio Lindman, y que además conservaban inexactitudes en la pertenencia étnica de los retratados, cosa que se debía a que el fotógrafo que en realidad había obtenido las imágenes, Manuel de San Martín de Asunción, no era "sabio, y poco se le importa de la etnografía, resulta que ha mezclado sus placas sin recordar más a que tribu se referían, y les ha dado una nomenclatura que si acierta en buena parte, muchas veces es equivocada" ${ }^{67}$. Y más adelante señala un error similar cometido en la publicación de los viajes del explorador francés Bourgade La Dardye (1889).

Estos debates nos llevan a componer una idea matizada de cuál era la concepción del procedimiento fotográfico entre los antropólogos de fines del siglo XIX e inicios del siglo $X X$, en el sentido en que lo señala Tucker (2005), buscando destacar aquellos

\footnotetext{
${ }^{66}$ Carta a Samuel Lafone Quevedo, Asunción 15 de Octubre de 1897(AHFMLP)

${ }^{67}$ Carta de Guido Boggiani a Samuel Lafone Quevedo, Asunción 22 de octubre de 1899 (AHFMLP)
} 
elementos que permitan ajustar el comúnmente aceptado "discurso de la mimesis" o de la objetividad mecánica. Como buscamos demostrar aquí, al poner en contexto estas imágenes -a través de la lectura y análisis de material bibliográfico y de archivo- la mirada de los antropólogos decimonónicos no era ingenua y ponía en juego distintos argumentos sobre selectividad, criterios, habilidad y estética, que tenían influencia en lo que se tomaba por objetivo y subjetivo en la fotografía científica. 


\section{CAPÍTULO III}

\section{LA FOTOGRAFÍA Y LA VISUALIZACIÓN DE TIPOS RACIALES EN LA OBRA DE ROBERT LEHMANN-NITSCHE}

En este capítulo vamos a ocuparnos de estudiar la aplicación del dispositivo fotográfico a los estudios de antropología física llevados adelante por Robert Lehmann-Nitsche, enfocando específicamente en el análisis del lugar que se le otorgó a la fotografía en la visualización de los tipos raciales. En ese marco se hace una breve referencia a la formación de Lehmann-Nitsche, su llegada al Museo de La Plata y las actividades que allí desarrolló, especialmente en lo que refiere a los estudios de antropología física, deteniéndonos en las concepciones que este autor manejaba sobre "raza" y "tipo racial". Posteriormente, y a fin de avanzar en el conocimiento sobre los límites que Lehmann-Nitsche reconocía en la utilización del procedimiento fotográfico, se analiza la discusión que entabló sobre el caso de Amadeo Bezzi. Se inicia luego el análisis del trabajo fotográfico-antropométrico realizado en 1899 por sobre un grupo de indígenas Takshik del Chaco argentino.

Las fotografías de esta colección, junto con las tomadas en el Ingenio La Esperanza en 1906 conforman, como vimos en el primer capítulo, casi la totalidad de las imágenes fotográficas sobre pueblos indígenas del Gran Chaco que se conservan en el Museo de La Plata. En ese sentido, la consulta de los materiales fotográficos de Lehmann-Nitsche conservados en el Instituto Iberoamericano de Berlin permitió complementar el estudio de las mismas, conformando un cuadro más amplio de las imágenes obtenidas en esas ocasiones. En este capítulo entonces se describen y analizan las circunstancias a través de las cuales fue posible para Lehmann-Nitsche acceder al estudio del grupo en cuestión, haciendo especial énfasis en la construcción del atlas fotográfico que fue publicado en 1904 en la revista del Museo de La Plata. Se tratan específicamente los criterios metodológicos puestos en práctica por el autor con el fin de acceder a la visualización del tipo racial takshik. 
Tal como veremos aquí, en su trabajo sobre los takshik, Lehmann-Nitsche incluyó una serie de fotografías dispuestas en forma de atlas con la intención de que a través de una mirada u ojeada (coup d'oeil) fuera posible lograr una síntesis de todas las imágenes vistas en un solo tipo abstracto. Un breve análisis de la construcción de ese atlas fotográfico nos permitirá profundizar nuestro conocimiento sobre la construcción visual de los tipos raciales en la antropología de fines del siglo XIX. Nos interesa indagar en cómo la observación experta distingue y estabiliza objetos científicos para una comunidad de investigadores, tal como lo plantea Lorraine Daston (2008). De acuerdo con esta autora, sin estos hábitos adquiridos de observación no habría ciencia, ni existiría un "mundo visible articulado"1. Las formas en las que la percepción genera nuevos objetos científicos son varias y complejas. En este sentido si bien los procesos implícitos de la percepción entrenada son fundamentales, ellos están vinculados con herramientas explícitas, incluyendo instrumentos estandarizados, descripciones e imágenes.

\section{Robert Lehmann-Nitsche, la antropología física y las definiciones de raza y tipo racial}

En julio de 1897, Robert Lehmann-Nitsche (1872-1938), quien era doctor en medicina y en filosofía por la Universidad de Munich comenzó a trabajar en el Museo de La Plata en 1897, contratado por recomendación del Dr. Rudolf Martin (profesor de antropología en las universidades de Zürich y Munich), haciéndose cargo de la "Sección Antropológica" de esa institución hasta 1930. Viniendo a reemplazar al antropólogo holandés Hermann ten Kate quien se desempeñó en ese cargo entre 1895 y mediados de 1897. Durante los 33 años que trabajó en el Museo de la Plata produjo una larga lista bibliográfica vinculada al campo de la antropología, dedicándose en sus primeros diez años de actividad a realizar estudios antropológicos sobre pueblos indígenas de la Argentina, especialmente de las regiones de Chaco, Patagonia y Tierra del Fuego. A su llegada al Museo reorientó los trabajos en la Sección Antropológica, reorganizando las

\footnotetext{
1 "Without these acquired habits of perception cultivated by observation, there would not only be no science; there would be no articulated visible (or auditory or tactile) world at all”. (Daston 2008:100)
} 
colecciones, con el objeto de realizar estudios ligados a lo que llamó "antropopatología", el estudio comparado de las patologías de las razas humanas, especialmente las relacionadas a los pueblos indígenas sudamericanos. A esta línea de investigación y al estudio físico más general de las "razas sudamericanas", Lehmann-Nitsche dedicó sus primeros diez años de trabajo en el Museo, y fue durante ese período y por su iniciativa que se produjeron la gran mayoría de los documentos fotográficos referidos a los pueblos indígenas del Gran Chaco.

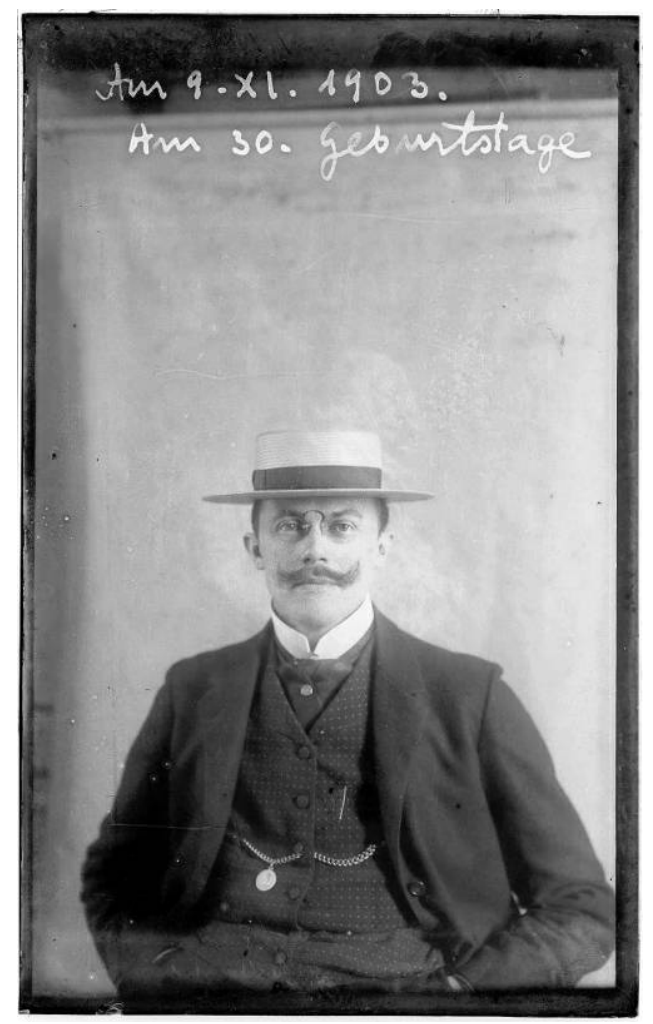

Figura 1. Robert Lehmann-Nitsche a los 30 años 9/11/1903. (Legado Robert Lehmann-Nitsche, IAI, Berlin)

Pocos meses después de haber llegado a Argentina, en el Primer Congreso Científico Latino-Americano, realizado en Buenos Aires en el otoño de 1898, Lehmann-Nitsche brindó una conferencia donde exponía las definiciones de la antropología y la craneología, sus subdivisiones, su objeto y las relaciones con otras disciplinas como la geografía y la lingüística (Lehmann-Nitsche, 1899d). Para él la antropología física era la antropología propiamente dicha, y su objetivo era "buscar la forma típica del cuerpo de la raza" (Lehmann-Nitche 1899d:134). Esto se lograba, en términos de los parámetros científicos de la época, contando con la colaboración del lingüista quien iría a apoyar y 
confirmar los resultados obtenidos por la antropología y también con el "indicio geográfico" ya que cada raza "tiene su ubicación propia y pertenece a una zona determinada", aunque estos dos últimos elementos eran de carácter secundario en relación a los caracteres somáticos (Lehmann-Nitsche 1899d: 133-140).

Más adelante definiría la que entendía por el concepto de raza: "un grupo somático, caracterizado por cierto número de rasgos comunes á todos los individuos que lo componen; es, pues, una unidad que puede variar en cierto grado entre sus dos extremos." (Lehmann-Nitsche 1904e:164). La "raza", para Lehmann-Nitsche, encerraba una cierta variabilidad que estaba dada por lo que denominaba influencias fisiológicas o biológicas, las que eran responsables de modificar "en alto grado á un organismo". Sin embargo para él los caracteres de una raza eran independientes de las condiciones exteriores, es decir, de lo que llamaba factores fisiológicos ó biológicos e incluso de los factores culturales, ya que entendía la cultura como "una especie de medio" a la que trataría como un "detalle de los factores fisiológicos" (Lehmann-Nitsche 1904e: 164165) La variedad individual y los distintos factores recién señalados daba como resultado que los individuos que conforman una raza sean muy diferentes entre sí; la antropología entonces, debía buscar "el tipo de la raza independiente de los factores biológicos, y lo quiere encontrar, con sus formas fundamentales, precisamente entre la multitud de los tipos biológicos." (Lehmann-Nitsche 1899d:134)

De esta forma vemos que la concepción de raza que manejaba Lehmann-Nitsche era por un lado de corte esencialista, ya que si bien esta podía ser influenciada por el medio -tanto fisiológico, biológico como cultural- en el que se desenvolvían los individuos, los caracteres típicos de la raza eran independientes de esos factores. La tarea entonces era la de tratar de llegar a esas características raciales inmutables dejando de lado la variabilidad individual producto de la influencia de los factores del medio. Estas "particularidades corporales" por otra parte eran infinitas por lo que, señala Lehmann-Nitsche, no se podían "describir, ni medir sino abstractivamente por buenas reproducciones ó exámenes visuales directos." (Lehmann-Nitsche 1899d: 134). 
A pesar de que reconocía un ejercicio de abstracción por parte del observador en la identificación y descripción de los caracteres raciales, consideraba que los grandes grupos humanos que representaban las distintas razas "existen positivamente y son verdaderas realidades; no los crea nuestra fantasía en su manía de sistematizarlos. Son principios fundamentales: nuestro punto de partida." (Lehmann-Nitsche 1899d: 131) Para Lehmann-Nitsche entonces, la "raza" no era un concepto teórico elaborado por el investigador a los fines de analizar la variabilidad humana sino que existía positivamente en la naturaleza, y su esencia podía ser capturada principalmente a través de la observación.

Por otro lado el concepto de "tipo" venía a articularse con esta noción de raza definida más arriba en el sentido de que era el elemento necesario para definir una determinada raza, por lo que la "antropología propiamente dicha" debía dedicarse principalmente a "buscar y fijar el tipo de raza, es decir, lo típico del cuerpo de la raza, evitando los indicios estraños." (Lehmann-Nitsche 1899d:133). En este sentido seguía las afirmaciones del antropólogo alemán Paul Ehrenreich para quien el tipo de la raza era "el polo negativo invariable, substancialmente eterno" (Ehrenreich 1897:36, citado en Lehmann-Nitsche 1899d:134). Lehmann-Nitsche consideraba que el tipo de una raza era "lo verdaderamente característico", aunque no era posible determinar lo característico en forma absoluta, ya que ello implicaba siempre una comparación, dependiendo además de los puntos de vista desde los cuales se efectúe esa comparación, lo que producirá otras tantas particularidades relativas (Lehmann-Nitsche 1904e: 162)

Estas afirmaciones acerca del objeto de la antropología y las definiciones de los conceptos de raza y tipo racial irían a contribuir al estudio de los pueblos indígenas sudamericanos. En ese sentido, Lehmann-Nitsche hacía suya una preocupación muy extendida por entonces acerca del destino de esos pueblos y las consecuencias que ello podía tener para su conocimiento: 
“... hay que apresurarse y salvar lo que aún existe para poder fijar los caracteres de todas ellas destinadas a desaparecer; $y$, con este material irreparable, poner en conocimiento de la posteridad las formas variadas del cuerpo humano, el desarrollo gradual y las innumerables manifestaciones de su espíritu. Esta es la tarea que moral y científicamente la antropología sudamericana debería seguir: tarea ardua con la escasez del material destruido por la pseudo-civilización, la cultura de la raza blanca; por su colonización y sus misiones; por sus religiones y sus fanatismos; enemigos de toda etnografía, de toda antropología." (Lehmann-Nitsche 1899d:123-24)

Asimismo, subrayaría la necesidad de desarrollar métodos especiales para describir los pueblos de la "raza americana" (Lehmann-Nitsche, 1904e). Como marca Podgorny (2005: 80-81) Lehmann-Nitsche pretendía aplicar en el contexto local una conciliación entre las escuelas antropológicas francesa y alemana. De acuerdo con esta autora, Lehmann-Nitsche combinaba los métodos, que entendía más convenientes de las distintas escuelas antropológicas, con otros de su creación. Por ejemplo, sostenía que "el método de Broca y las recomendaciones de la convención de Frankfurt (Frankfurter Verständigung) representaban elementos 'esencialmente métricos', poco centrales en el desarrollo de la disciplina (...) de tal manera, siendo tan poco importante la adhesión a uno u otro método, lo más importante residía en saber compararlos" (Podgorny 2005 : 80-81) Esta conciliación entre las escuelas antropológicas francesa y alemana se daba no solamente en el plano de las mediciones craneanas sino que también, como veremos aquí, buscaba complementar las distintas concepciones sobre los alcances y posibilidades de la fotografía para el conocimiento de los tipos raciales, tal como se definía desde la Escuela de Antropología de Paris como desde el "método" utilizado por el profesor de fisiología de la Universidad de Berlin, Gustav Fritsch (1838-1937). Este último, al igual que Lehmann-Nitsche, poseía un doctorado en medicina y otro en ciencias naturales, y había desarrollado un extenso trabajo sobre la fotografía utilizada en los estudios antropológicos, además de un particular método de aplicación de ese procedimiento del que, como veremos luego, Lehmann-Nitsche intentó valerse. 
De esta forma, construyendo su propios métodos y técnicas de estudio de acuerdo con las características de su objeto y las limitaciones impuestas por el medio local, Lehmann-Nitsche tomaría una postura "polémica y 'liberada' de los métodos inventados en Europa,(...) un "estar aquí" metodológico que creaba una marca de identidad y discutía con los parámetros enunciados en otros contextos." (Podgorny 2005: 81)

\section{Robert Lehmann-Nitsche y la aplicación de la fotografía en los estudios antropológicos.}

La fotografía ocupaba para este antropólogo un destacado lugar en el conocimiento y estudio de la tipología física de los primeros pobladores americanos. Se trataba no solamente de una técnica de registro ágil y eficaz sino que también, dadas sus peculiares características, permitía realizar un cómodo estudio en el gabinete de todo lo registrado. Disponer de grandes series de imágenes depositadas en los museos haría posible la repetición de la observación y de la comparación cuantas veces se hagan necesarias. De esa manera el aparato fotográfico ofrecía una representación controlada y rigurosa del objeto en estudio, un instante recortado de su existencia real lo suficientemente reducido como para ser examinado en el laboratorio (Martínez 2009).

Para el caso particular de la comunidad antropológica alemana, donde Lehmann Nitsche se había formado y con cuyos miembros estaba en contacto frecuente ${ }^{2}$, los instrumentos ópticos ocupaban un lugar preponderante, ya que observar objetos era considerado como una fuente más segura de conocimiento que la lectura de textos. Una forma de conocimiento que Zimmerman (2003) denomina "antihumanista", al destacar que la óptica de la antropología alemana era un modo de ver, una clase particular de mirada antropológica que buscaba diferenciarse por un lado de la mirada

\footnotetext{
${ }^{2}$ No podemos, sin embargo señalar a Lehmann-Nitsche como "representante de la antropología alemana en Sudamérica", no contamos aún con estudios en profundidad que den cuenta de su actividad profesional, su obra científica y su lugar en la comunidad antropológica internacional. Aunque esta tesis significa un aporte para el conocimiento de su particular concepción de la fotografía, las tareas arriba mencionadas, escapan y exceden por largo los objetivos aquí planteados.
} 
lasciva del gran público que asistía a las ferias, exhibiciones y jardines de aclimatación consumiendo imágenes exóticas y que por otra parte también se diferenciaba de la visión de los humanistas -también alemanes- para quienes los sujetos de la antropología eran sujetos de conocimiento. En este sentido la construcción de una visión "sin perspectiva" fue un movimiento polémico en su momento, tanto en contra del humanismo y las comprensiones interpretativas de las ciencias humanas como en contra de una fascinación popular y voyeurística con lo exótico. Ellos consideraban que su visión podía ser "aperspectiva" en tanto posibilitada por los medios ópticos entonces desarrollados (Zimmerman 2001: 386).

Es así que durante el siglo diecinueve, y no sólo para los antropólogos alemanes sino también para los franceses por ejemplo, se dio prioridad a las cosas por sobre las palabras como instrumentos de conocimiento, debido al poder relativo de los objetos y artefactos -entre los cuales podemos considerar a las fotografías- para ofrecer una impresión vívida (Dias 1994a: 164-165). Sin embargo, tal como señala Broeckmann (2008), quien discute la obra del antropólogo alemán Gustav Fritsch, no hay en la actualidad entre los historiadores de la fotografía y la antropología un consenso acerca del estatus que este procedimiento tuvo durante el siglo XIX. Por un lado Zimmermann (2001 y 2003) nos habla de un fuerte enfoque visual por parte de los antropólogos alemanes de ese período, a la vez que Elizabeth Edwards $(1992,2001)$ pone el énfasis en la importancia de la fotografía como evidencia y también como objeto de intercambio entre los antropólogos y etnólogos de fines del siglo XIX.

Contrariamente a estos argumentos se expresa el mismo Broeckmann, para quien la fotografía fue tomada seriamente solo por un pequeño número de científicos y su utilización fue marginal (Broeckmann 2008: 150-151). Asimismo, Nelia Dias (1994b) señala, refiriéndose a la academia francesa, que allí la fotografía antropométrica fue puesta en cuestión por reconocidos antropólogos como Paul Topinard (1830-1911), para quien la imagen fotográfica más correctamente tomada según las reglas científicas deseadas no podía reemplazar las buenas medidas y descripciones, ya que 
no podrían dar más que una proyección central con todas sus ilusiones (Topinard 1881: 760, citado en Dias 1994b: 41). En este sentido Dias, refiriéndose al retrato antropológico, señala que este sufrió un declive en su utilización como herramienta científica al no poder brindar representaciones convincentes de los "tipos raciales", cayendo finalmente en descrédito después de la década de 1880, cuando las mismas nociones de raza y tipo fueron cuestionadas, y los caracteres craneanos, en especial el índice cefálico crecieron en importancia. (Dias 1994b: 42)

Sin embargo, al momento en que Lehmann-Nitsche comenzaba su carrera profesional en el Museo de La Plata, hacia fines de la década de 1890, la craneología y la craneometría estaban siendo fuertemente criticadas, tanto por Ehrenreich como por otros autores de habla alemana como Aurél von Török (1842-1912) o Konrad Rieger (1855-1939) (Lehmann-Nitsche 1899:140). En este contexto si bien Lehmann-Nitsche no renegaba de la utilidad de las mediciones para el estudio de la variabilidad racial, consideraba que la imagen fotográfica podía brindar una buena contribución a estos propósitos. Lehmann-Nitsche, recordemos, nunca tuvo un papel significativo en la antropología y, a pesar de sus cargos como funcionario argentino, en muchos casos se comportó como un proveedor de datos más. En ese sentido, no entendía a la fotografía como un mero complemento de las observaciones antropométricas sino que les asignó un lugar clave en el estudio de las razas americanas, tal como él mismo lo expresara, por ejemplo, en uno de sus trabajos:

"La PARTE FOTOGRÁFICA de nuestro trabajo desempeña efectivamente un papel principal en la presente obra. [...] Para la descripción se adoptaron formularios breves que contenían solamente aquellos rasgos que no resaltan del estudio de la fotografía. Integrar por completo los formularios que se recomiendan en los gabinetes de antropología, exige demasiado tiempo, y no da tampoco mayores resultados; mientras que la fotografía, por el contrario, permite, sin palabras de más, y con ahorro de tiempo, un estudio prolijo en el gabinete, en el que uno puede trabajar con toda tranquilidad." (Lehmann-Nitsche 1907a: 55). 
Podemos ver en esta cita que Lehmann-Nitsche valoraba la contribución del procedimiento fotográfico en relación a la economía del proceso de conocimiento en sus propias obras, ya que permitía ahorrar no sólo tiempo sino también espacio, a la vez que posibilitaba ejercer mayor control sobre la indagación. Por otra parte sin embargo, este antropólogo era también consciente de las limitaciones y dificultades de aplicación de ese medio al estudio del hombre.

En la revista Criminalogía Moderna de 1899 se publicó una nota firmada por el Dr. Ricardo Del Campo titulada "La monstruosidad en la delincuencia". Se presentaba el análisis del caso del joven Amadeo Bezzi, joven italiano venido a la Argentina desde muy pequeño, quien presentaba una "anomalía morfológica" que constituía, según el autor, un "fenómeno teratológico" (Del Campo 1899: 292). Bezzi había sido acusado de tentativa de violación ${ }^{3}$ y se hallaba detenido en la comisaría de La Hornos (La Plata). Las características físicas de este hombre serían examinadas por Del Campo mediante la fotografía de Bezzi que habían tomado las fuerzas de seguridad ${ }^{4}$. Decía este autor: "Como puede apreciarse aún al simple examen del retrato que reproducimos, Amadeo Bezzi es un caso típico de monstruosidad congénita por defecto de desarrollo, en el sentido de una incompleta soldadura de las dos partes laterales del cráneo." (Del Campo 1899: 292)

\footnotetext{
${ }^{3}$ Así describe Del Campo las circunstancias de su detención: "Amadeo Bezzi (a) El ñato, italiano, de 18 años de edad, se halla acusado y convicto de tentativa de violación en la persona de una sordomuda, en complicidad con un tal Cornaggia conocido bajo el apodo de El rengo en razón de tener una pierna amputada, y otro individuo más de apellido Mortarelli.

Sorprendida la víctima mientras recogía leña en una vía pública de la sección Hornos, jurisdicción de La Plata, fue arrojada al suelo y sujetada por Bezzi (a) El ñato, mientras El rengo se lanzaba sobre ella á fin de satisfacer con violencia su excitación brutal.

La escena macábrica y morbosa que debió presentarse á los agentes de policía que oportunamente intervinieron, es de un siniestro realismo que la pluma es incapaz de reflejar.

Una sordo-muda débil y adolescente apenas, que se debate en la impotencia y en defensa de su honor, haciendo esfuerzos desesperados y lanzando alaridos guturales, inarticulados, de espanto y de dolor; un sér doblemente monstruoso y repugnante que la sujeta y lastima entre sus brazos de hierro, para entregarla indefensa á las más abyectas violencias de un inválido de miembros mutilados, de una bestia humana enardecida por un desenfrenado instinto sexual, es algo que no ha estado jamás en las previsiones realistas de los Zola, ni menos aún en los delirios fantásticos de los Poe." (Del Campo 1899: 292-293)

${ }^{4}$ Atribuimos la autoría de esta foto a las fuerzas de seguridad debido a que Del Campo ya en su publicación de 1899 incluye el retrato de frente de Bezzi, que luego apareció en la Revista del Museo de La Plata de 1904 junto con los dos retratos de perfil izquierdo y derecho; aunque ni ese autor, ni Lehmann-Nitsche, brindan datos a la autoría de este conjunto de imágenes.
} 


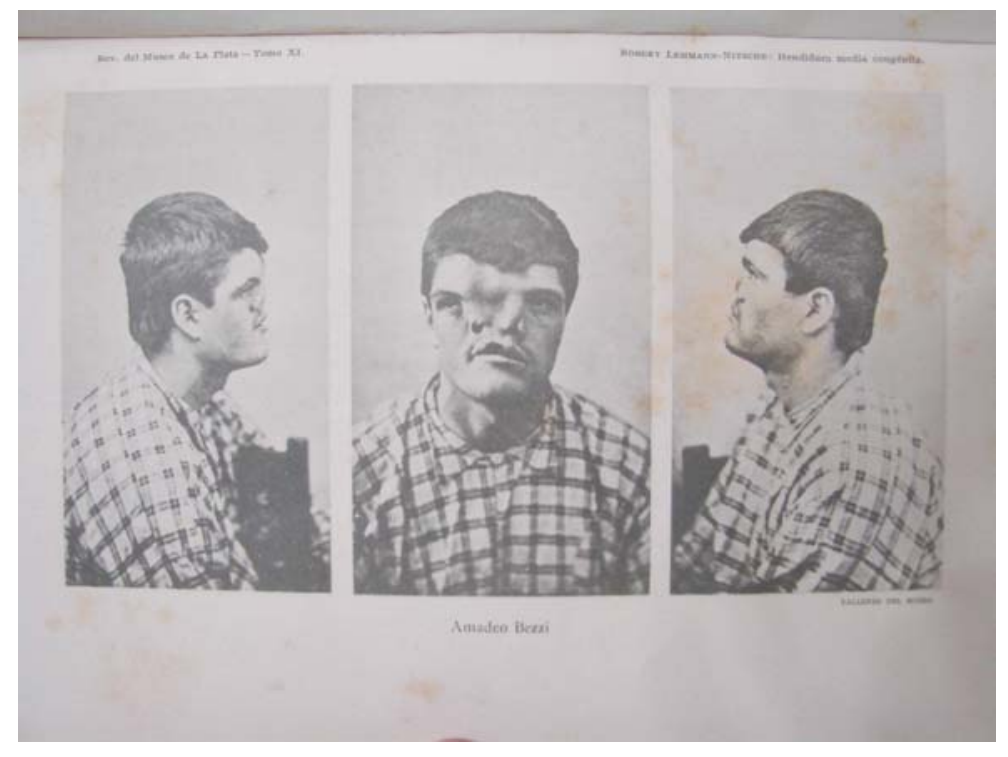

Figura 2. "Amadeo Bezzi” (Lehmann-Nitsche 1904b).

Según señala Del Campo, la fisonomía de Bezzi no encajaba en "el cuadro general de estigmas adoptado por el método lombrosiano", ya que estos caso de "monstruosidad fisiopsíquica" cuando no conducen a la muerte "son causa general de la imbecilidad completa del sujeto que pasando al estado de automatismo, no se halla en condiciones de delinquir." (Del Campo 1899: 292). Sin embargo este autor no se priva de relacionar las características físicas de Bezzi con su comportamiento moral, señalando que este último resulta una excepción a las leyes enunciadas por el criminalista Lombroso ${ }^{5}$, señalando que se trataba de "un ser doblemente horroroso y repugnante". De esta forma, a partir de un retrato fotográfico, Del Campo ensayaba una descripción de los rasgos del rostro y cráneo de Bezzi y luego de relatar las circunstancias que llevaron a su detención concluye que "En la determinación del delito cometido por Bezzi, obra

\footnotetext{
${ }^{5}$ Ezechia Marco Lombroso (1835-1909), conocido bajo el seudónimo de Cesare Lombroso, fue un psiquiatra y antropólogo italiano, reconocido como fundador de la antropología criminal. Enseñó en las Universidades de Pavía y de Torino y dirigió el hospital psiquiátrico de Pesaro (1871). En su obra fundamental, L'uomo delinquente (1876), expuso los principios de una criminología experimental, fundada en el positivismo, para la cual el delincuente es un tipo antropológico, determinado por anomalías físicas, aunque posteriormente atenuó esta teoría. La antropología criminal de Lombroso y sus estudios basados en el campo de la psiquiatría, el derecho penal y la eugenesia proporcionaron a los intelectuales argentinos "un vasto arsenal de ideas y de propuestas" (Scarzanella 1999: 104). En este sentido Gina Lombroso Ferrero, hija de Cesare Lombroso, sostenía que la Argentina había entendido y aplicado las ideas de su padre antes y mejor que cualquier otro país. Aunque, según Salvatore esto es solo parcialmente cierto, ya que en determinado momento la criminología positivista perdió su carácter novedoso como corriente intelectual y política. Sin embargo sus procedimientos, métodos de disciplina y categorías sobrevivieron como prácticas estatales y razones de gobierno (Salvatore 2001: 112-114)
} 
sobre un fondo de degeneración congénita, otro estímulo de naturaleza ocasional." (Del Campo 1899: 293).

Las afirmaciones de este último autor fueron blanco de las críticas de Lehmann-Nitsche en el artículo titulado "Un caso raro de hendidura media congénita de la parte facial superior" y publicado en el Tomo XI de la Revista Museo de La Plata. Lehmann-Nitsche ya había tenido contacto con Bezzi en 1897, cuando este último se hallaba en la comisaría de Los Hornos, acusado de haber robado quinientos pesos a un inquilino de su madre. Allí, como el nos comenta “... gracias a la amabilidad del señor comisario, me fue posible observarle y estudiarle detenidamente el día 12 de diciembre del año citado [1897]"'. Los resultados de este primer examen no fueron publicados sino hasta 1904. Luego de publicado el artículo de Del Campo, en agosto de 1899, y tal vez animado por ello, Lehmann-Nitsche vuelve a visitar a Bezzi, en enero de 1900 cuando “... mi distinguido amigo el señor Vucetich, jefe de la sección antropométrica de la Policía de la Provincia, me proporcionó la posibilidad de hacerle una visita a Bezzi en la cárcel, pudiendo de este modo complementar y ampliar mis primeras observaciones, anotadas desde hacía ya más de dos años." (Lehmann-Nitsche 1904b:4) ${ }^{8}$.

Sus críticas a Del Campo están enfocadas en los aspectos metodológicos de ese trabajo, señalando que estos errores se dieron por dos motivos. Primero, el hecho de que Del Campo haya sido abogado y no médico, ya que, para Lehmann-Nitsche, las particulares características físicas de Bezzi no se vinculaban con cuestiones de índole

\footnotetext{
${ }^{6}$ Continuaba Del Campo afirmando que: "Se comprende que un ser cuyo aspecto físico es defectuoso hasta la monstruosidad y cuyas condiciones psíquicas corresponden proporcionalmente a la morfología exterior, encuentra en ello un inconveniente insalvable para satisfacer normalmente las necesidades fisiológicas del desarrollo sexual, y se explica a la vez que en tales circunstancias haya recurrido a la violencia como único medio a su alcance de lograr aquel fin, bajo la excitación consiguiente a una prolongada y forzosa abstención.

Es el delito correspondiente á la miseria de amor, como lo es el robo á la miseria de nutrición." (Del Campo 1899:293)

${ }^{7}$ En los archivo policiales pudimos hallar además, una entrada anterior de Bezzi en esa dependencia donde se lo describía de la siguiente manera: "menor, fugado de casa de sus padres, según lo comunica el señor Comisario de la Sección 5a., en despacho fecha 27 del pasado: - la filiación, es: - Italiano, de 16 años, alto, regular grosor, pelo castaño, cara chata, de aspecto repugnante, a consecuencia de una deformación general en la nariz, frente y ojos; viste saco y sombrero chambergo negro, pantalón claro, botines gruesos, de becerro y es muy gangoso."(AHMSPB Ordenes del Día de Policía, 1897)

${ }^{8}$ Lehmann-Nitsche había entablado una relación profesional y de intercambio bibliográfico con Juan Vucetich a instancias del anterior jefe de la sección antropológica del museo, Hermann ten Kate. (Legado Robert LehmannNitsche, IAI, Berlin, N-0070 b 684)
} 
jurídico-legal sino físico-anatómicas. En ese sentido, ya desde el título de ambos trabajos podemos observar las diferentes perspectivas de los autores; mientras que Del Campo relacionaba los caracteres físicos de Bezzi con su conducta social (La monstruosidad en la delincuencia), Lehmann-Nitsche abordaría este caso como estrictamente médico.

En segundo lugar, relacionado con lo anterior y que aquí más nos interesa, la descripción de la "anatomía patológica" de Bezzi que realiza Del Campo, se basaba "en la fotografía del individuo sin haber examinado a éste en persona." (Lehmann-Nitsche 1904:3-4), poniendo el acento en la exclusiva pertinencia del saber y la metodología médica para estudiar este caso, y señalando además un límite importante en el uso de la fotografía con fines científicos. Finaliza este autor refiriéndose a la rareza de estos casos y al interés relativamente reciente de la ciencia en ellos. No traza, a diferencia de Del Campo, un vínculo entre las condiciones físicas, entre la "monstruosidad física" de Bezzi, y su comportamiento moral y social, ni tampoco lo vincula con su psicología. En este sentido, ya en 1898, en el marco del Primer Congreso Científico Latino-Americano, Lehmann-Nitsche se había pronunciado en contra de la utilización de la "craneología" de Lombroso, polemizando su contribución a la antropología y al estudio de la diferencia racial (Rodríguez 2006: 36) ${ }^{9}$.

De este modo podemos señalar que si bien el dispositivo fotográfico era visto por este antropólogo como una herramienta eficaz para el conocimiento de las "razas", un concepto que, como vimos más arriba, tenía para él un carácter abstracto, no pensaba lo mismo cuando se lo quería aplicar a los estudios somáticos o físicos ${ }^{10}$ ligados al campo de la medicina. Aunque las imágenes fotográficas pudieran resultar útiles a modo de ejemplo e ilustración, no eran para Lehmann-Nitsche condición suficiente para emitir un diagnóstico médico, marcando de esta forma un límite importante en el uso y

\footnotetext{
${ }^{9}$ De hecho algunos años más tarde Lehmann-Nitsche se lamentaría por el extendido uso que había ganado el término "antropología criminal", "pues no se trata del examen (físico o somático comparativo) de criminales de diferentes razas, sino de individuos criminales en general" (Lehmann-Nitsche 1919: 81).

10 Lehmann-Nitsche utilizaba estos dos términos en forma de sinónimos, empleándolos "indistintamente, para designar todo aquello que se refiere al cuerpo material de una persona." (Lehmann-Nitsche 1919: 81).
} 
valor de la fotografía en el contexto de distintas disciplinas científicas. Incluso para el caso de los estudios antropológicos, Lehmann-Nitsche consideraba que la fotografía era un procedimiento que podía ser mejorado para lograr los fines deseados. Por ello, al igual que muchos de sus colegas en los países centrales estaba, como veremos más adelante, preocupado por definir el modo en que ese procedimiento resultara en un aporte significativo para sus estudios antropológicos.

La relación de Lehmann-Nitsche con la fotografía como herramienta para la investigación antropológica comenzaría algo más de un año después de su llegada a La Plata ${ }^{11}$. En 1898, realizaba su primer trabajo de antropología física sobre pueblos indígenas en la Exposición Nacional de Buenos Aires, adonde iría acompañado por su compatriota Carlos Bruch quien, como ya vimos, se venía desempeñando en calidad fotógrafo en el museo desde fines de 1887. En esa ocasión se midió y retrató a un grupo de indígenas selk-nam, que habían sido llevados por el Gobernador del Territorio de Tierra del Fuego (Lehmann-Nitsche 1916). En el marco de las ferias y exhibiciones de fines del siglo XIX y principios del siglo XX era frecuente que se tomen fotografías y medidas antropométricas, incluso las sociedades científicas proveían de certificados de "autenticidad étnica" de las personas exhibidas, sugiriendo a los empresarios aquellos grupos indígenas que podían ser de interés tanto a sus propósitos comerciales como a los de la ciencia (Corbey 1993:356) (Cfr. Báez 2004; Báez y Mason 2006).

Uno de estos grupos por ejemplo, eran los toba takshik, considerados una "tribu feroz", y que habían sido acusados de la muerte del explorador español Ibarreta hacia 1898. Al año siguiente, el célebre actor José Podestá había contratado un grupo de indígenas pertenecientes a este pueblo, planeando llevarlos a Paris, para exhibirlos en la Exposición Internacional de 1900. Al no permitirse su salida del país, ese contingente fue alojado en el Asilo Correccional de Mujeres regenteado por las Hermanas del Buen

\footnotetext{
${ }^{11}$ Si bien Lehmann-Nitsche incluyó tres fotografías en su trabajo sobre Bezzi, una de esas tres fotografías, aquella que lo muestra de frente a la cámara ya había sido incluida en la comunicación del Dr. Del Campo de agosto de 1899. En este sentido, teniendo en cuenta que ninguno de los dos autores aportan datos sobre la autoría de esas fotos, podemos suponer que ellas fueron tomadas por alguno de los organismo de seguridad que tuvieron a Bezzi a cargo, aunque no pudimos confirmar si se trató de la policía o del servicio penitenciario.
} 
Pastor. Hacia allí se dirigieron nuevamente Bruch y Lehmann-Nitsche con la intención de medirlos y fotografiarlos.

\section{"Un tráfico inmoral", los takshik en Buenos Aires.}

En setiembre de 1899 el empresario uruguayo de la compañía de dramas criollos, José Podestá (1858-1937) trajo a Buenos Aires a un grupo de indígenas toba takshik provenientes del Territorio Nacional de Formosa (Chaco argentino) con la intención de viajar a Europa para realizar una serie de presentaciones teatrales en España y exhibirlos en la Exposición Universal de Paris de 1900. Según Podestá, los empresarios Francisco Pastor y Eduardo Iribarne le habían propuesto representar el "Juan Moreira"12 en España "agregando un grupo de indios auténticos que exhibieran sus costumbres; vistiéndolos con relativo lujo de detalles, aunque se falseara en parte la verdad en beneficio de la estética y exigencia de teatralidad." (Podestá 2003: 100). Podestá entonces se había comprometido a conseguir "los indios Pilagas (orejudos) que estaban prisioneros en Formosa, complicados en el asesinato del explorador Ibarreta" (Podestá 2003:100) ${ }^{13}$.

Estando en Formosa, finalmente se traslado hasta un ingenio azucarero ${ }^{14}$ donde logró convencer a un grupo de trabajadores indígenas, 24 entre hombres y mujeres, para que lo acompañen a Buenos Aires (Podestá 2003: 100). Como lo estipulaba una

\footnotetext{
12 Esta obra era una adaptación en forma de "mimodrama" para su representación en el circo de la novela "Juan Moreira" escrita alrededor de 1880 y realizada por su propio autor Eduardo Gutiérrez. En 1886 José Podestá le puso letra a la obra tomándola de la novela representándola durante varios años y convirtiéndola en uno de los más importantes éxitos del teatro rioplatense.

13 En este sentido Podestá señala además que al llegar a Formosa logró trasladarse hasta el ingenio gracias al caballo que recibió prestado por el comandante Buchardo [SIC] (Podestá 2003:101). Este militar, que en realidad se llamaba Daniel Bouchard y llevaba el grado de teniente, era quien había dirigido las operaciones por tierra en busca del explorador español Enrique de Ibarreta, las que, tal como señala Miller (1999) formaron parte de una serie de crudas expediciones punitivas que gradualmente socavaron la capacidad de lucha indígena. Durante estos ataques los soldados atacaron las poblaciones indígenas quemando viviendas y matando a todo el que osara resistirse, lo que llevó a una disrupción en la organización política de muchos de los grupos de esa área al exterminar a sus líderes guerreros (Miller y otro 1999: 13).

${ }^{14}$ Para 1898 había dos ingenios azucareros funcionando en el territorio de Formosa, uno se encontraba en la, por ese entonces, colonia Formosa, propiedad de Mayer y Bonaccio, y otro en colonia Bouvier, más cercano a la actual ciudad de Clorinda, de los hermanos Nougués (Congreso Nacional 1898: 325). Es probable que Podestá haya contratado a los takshik en el primero de estos establecimientos.
} 
reciente disposición judicial los contratos que se celebraran con indígenas ${ }^{15}$ debían realizarse ante el Defensor de Menores e Incapaces de ese territorio (Pestalardo 2006) por lo que debieron dar nombres "cristianos" a los takshik ${ }^{16}$. Según comenta Podestá, cuando estaban partiendo para Buenos Aires el dueño del ingenio se enteró de lo que estaba ocurriendo y telegrafió a los medios porteños "diciendo un montón de embustes" de los cuales se hicieron eco (Podestá 2003: 100-101). Una vez llegado a Buenos Aires con su "troupe", el ministro de Justica e Instrucción Pública, Osvalo Magnasco ordenó dejar a los takshik a disposición de la justicia. Podestá protestó ante la corte con resultado negativo por lo que se ordenó que los indígenas regresaran a Formosa ${ }^{17}$.

El intento de llevar a los takshik a Paris impedido por la justicia, generó además de los perjuicios que alegaba Podestá, un gran debate en los tribunales y en la prensa porteña $^{18}$. En el dictamen sobre este asunto expedido por el Dr. Sabiniano Kier, Procurador General de la Nación, se decía que

"La prensa de la capital ha denunciado un tráfico inmoral, una exportación de productos humanos indígenas de la Argentina, con el propósito de exponer, en el grandioso certamen de la civilización alcanzada en el universo entero al iniciarse el siglo XX, la enseñanza lastimosa de la miseria y de la barbarie de una tribu indígena; y esto cuando la Argentina no tendrá otra representación ante los millones de visitantes de la

\footnotetext{
${ }^{15}$ Este contrato lo obligaba a alimentar a los takshik, enseñarles leer y escribir, cuidar de su salud y depositar en un banco mensualmente 15 pesos por cada uno (Podestá 2003: 100).

${ }^{16}$ De acuerdo con Pestalardo, estos nombres eran: "Antonio Bochar, José Castagnino, Carlos Palmarini, Camilo Jiménez, José Caroya, Sofía, Amelia, Zulema, Maipú, Argentina, Anita, Baldomera, Esther, Eva, Amelia, María, Arminda, Marta y Carmen" (Pestalardo 2006) Obsérvese que solo a los hombres se los inscribió con apellido. En este sentido señalaba un juez de Formosa que los indígenas "se bautizaban sin mayores formalidades (...) omitiéndose su inscripción en el registro civil. Se les daba un nombre como a una cosa, o a un animal doméstico." (Garmendia 1901: 60)

17 “Con todo, llevé el asunto hasta la Corte, y, allí me cortaron en definitiva: dos votos contra uno. Este único voto me demostró que alguna razón debía tener yo cuando un miembro de la Corte votó en mi favor; mi abogado el Dr. Juan Coustau, en su informe in voce, hizo cuanto pudo para demostrar que esos infelices indios ganaban en el cambio de vida, pues además de civilizarse serían útiles a la patria y a sus semejantes, en tanto que en la forma en que vivían en el chaco serían todo lo contrario." (Podestá 2003:102)

${ }^{18}$ Por ejemplo el diario porteño La Nación publicó distintas noticias referidas a este tema los días 3, 7, 8, 9, 15, 22 y 26 de septiembre y 4 de octubre de 1899.
} 
exposición universal que aquellos desgraciados indígenas arrancados de los hogares a los afectos naturales de su familia." ${ }^{" 19}$

A pesar de esgrimirse la defensa de los "afectos naturales" de los Takshik como una de las razones para prohibir su salida del país, calificando ese intento como "tráfico inmoral", puede interpretarse que el principal fundamento para ello se originaba en la vergüenza que, para las autoridades nacionales, representaba exhibir "la enseña lastimosa de la miseria y de la barbarie de una tribu indígena" en el Pabellón Argentino de ese multitudinario evento, considerado como el "grandioso certamen de la civilización alcanzado en el universo entero al iniciar el siglo 20". De esta cita se desprende además, que no solamente la imagen sino también las condiciones objetivas de existencia en las que se hallaban los pueblos indígenas, a quienes se consideraba parte de un estadio de civilización ya superado, iban en contra de lo que Argentina debía mostrar en el evento más renombrado del "mundo civilizado" a fines del siglo diecinueve. Un país con indios no podía considerarse parte de ese mundo, y menos aún un país que permitiera traficar con seres humanos de ese modo.

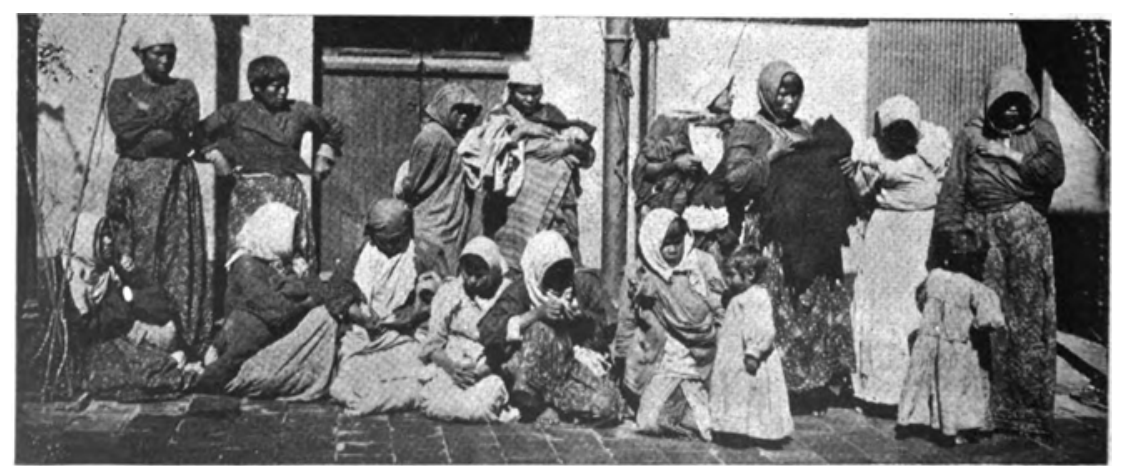

Figura 3. "Los Indios contratados para la Exposición de París. Grupos de familias indias de las tribus pilagas del Chaco pertenecientes á la troupe Podestá alojadas en la Cárcel Correccional de Mujeres por disposición del Ministro de Instrucción Pública". (Revista Caras y Caretas $\mathrm{N}^{\circ} 49$, 9/9/1899) Aquí vemos al igual que en la Figura 4, 14 mujeres junto a algunos niños.

Sin embargo lo que hubiera sido una vergüenza para las autoridades y la prensa argentina resultó en una ausencia lamentable para los antropólogos europeos que los hubieran podido observar en Paris ${ }^{20}$. Por lo menos así lo manifestaba Lehmann-Nitsche quien rápidamente hace notar el valor que el estudio de este grupo tendría para el

\footnotetext{
${ }^{19}$ La Nación 15/9/1899, pág. 6.

20 En relación a esto decía Podestá: "Los norteamericanos no se avergonzaron cuando Búfalo Bill llevó a Europa los Pieles Rojas. Cuestión de puntos de mira." (Podestá 2003:102)
} 
conocimiento antropológico de los pueblos indígenas sudamericanos. Se trataba de una parcialidad del pueblo Toba quienes, desde el momento del inicio de la conquista y colonización del Chaco, eran considerados entre los más "feroces y salvajes", y a quienes se adjudicaba, entre otras "crueldades", las muertes del explorador Creveaux y su compañero Billet ${ }^{21}$. Una vez llegados a Buenos Aires y hasta tanto la justicia se expidiera sobre su destino los indígenas fueron alojados en el Asilo Correccional de Mujeres $^{22}$, hacia donde acudió Lehmann-Nitsche aprovechando la oportunidad para realizar una serie estudios antropométricos sobre este grupo, previa autorización de la Justicia ${ }^{23}$.

Desde el inicio de este trabajo Lehmann-Nitsche se topó con varios obstáculos. En primer lugar el grupo takshik que se alojaba en Asilo del Buen Pastor estaba compuesto por mujeres y niños pequeños habiendo solamente dos muchachos jóvenes ${ }^{24}$, de forma que no pudo trabajar sobre varones adultos, lo cual, para los estudios de antropología física era una condición importante efectos de comparar los resultados obtenidos con otros estudios similares de manera confiable. De ese modo, esta situación, según sus propios criterios y lo que él mismo manifestara, disminuyó notablemente el valor científico de su trabajo. Por su parte las mujeres y niños se hallaban bajo la custodia de una orden religiosa femenina, y esto resultó ser otro obstáculo para el antropólogo alemán ya que esas religiosas se opusieron a que se realizaran fotografías y mediciones de sus cuerpos al desnudo ${ }^{25}$.

\footnotetext{
${ }^{21}$ Lehmann-Nitsche comunicó los resultados de este trabajo en el $X$ Congreso de Americanistas celebrado en París en 1900. En la nota concisa sobre esa comunicación que fue publicada en las actas de ese encuentro se indicaba lo siguiente: "Ce sont ces indigénes qui ont assassiné nos deux compatriotas Creveaux et Billet"(Lehmann-Nitsche 1904a: 263)

${ }^{22}$ Este establecimiento había sido fundado en 1892, tenía una capacidad para 250 personas y estaba destinado a mujeres y menores, generalmente los hijos de las mismas internas. Esta cárcel estaba regenteada por las hermanas del Buen Pastor, una orden católica que en América dedicó sus esfuerzos a la readaptación de la mujer detenida. (Cúneo 1971:36-40)

${ }^{23}$ El Dr. Osvaldo Magnasco, Ministro de Justicia e Instrucción Pública de la Nación, fue quien autorizó la visita a los takshik de este antropólogo.

${ }^{24}$ Los dos varones de mayor edad tenían entre 18 y 20 años (Sierolek y Tarnardí), luego había dos adolescentes de entre 12 y 14 años (Nróik y Tschaiek), un niño de 10 años (Huashkiní) y otro de 3 años aproximadamente (Sápolék). (Lehmann-Nitsche 1904a)

${ }^{25}$ En realidad no pudo tomar fotografías antropométricas de las mujeres, pero sí pudo hacer esto con los niños y hombres jóvenes que se encontraban allí. (Lehmann-Nitsche 1904a:264)
} 


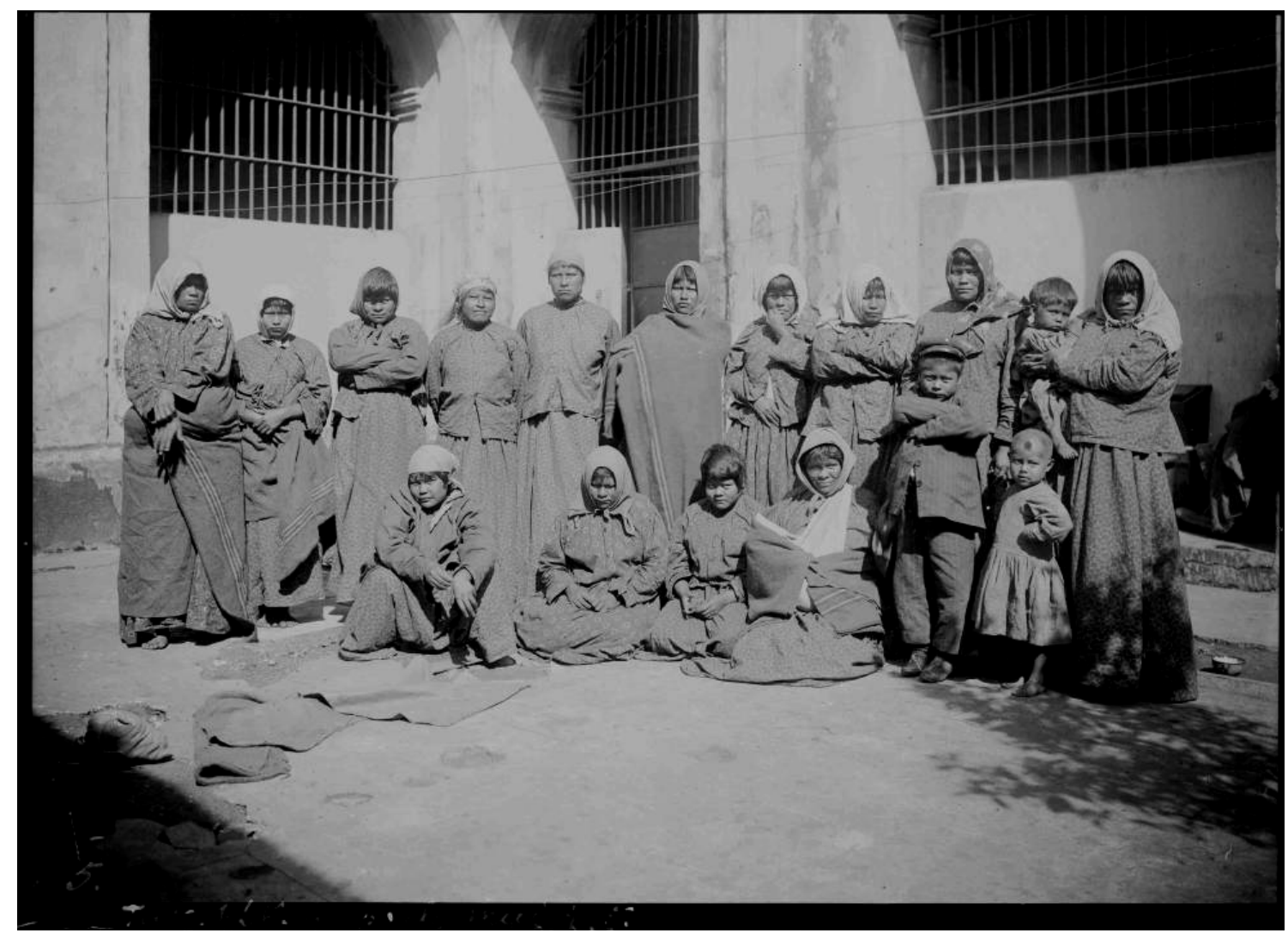

Figura 4. "5. Takshík. Grupo de mujeres" (C. Bruch, Buenos Aires, 1899) (DAMLP)

En esta fotografía se representa a 18 personas del grupo de 23 Takshik que se hallaban en setiembre de 1899 en la Carcel Correccional de Mujeres, 14 mujeres y 4 niños. Paradas, de izquierda a derecha, tenemos a Kapieré, Palagishí, Kaikaná, Noikenraé, Sokeiná, Huoronatá, Parané, Serainerlé, Nainrainá, Arailná con su hija Alolé en brazos. Huashkini, quien no fue medido, es el niño de gorra que está cruzando los brazos. Junto a él se encuentra Sapolék, tomando de la mano a su madre. Sentadas, de izquierda a derecha, se encuentran Nrainrlé, Pelokoná, Koássená y Metaigishé. Nótese en esta última mujer la posición de sus brazos y la faja blanca que cruza por encima de su hombro izquierdo, lo que indica que está cargando un bebé, del modo tradicional en que las indígenas chaqueñas cargan a sus hijos. No podemos confirmar sin embargo si este niño es Lederaik, hijo de Serainerlé o Aiká hijo de Huoronatá ${ }^{26}$. Junto con uno de estos dos últimos niños no encontramos retratados en esta fotografía a los hombres jóvenes y adolescentes: Siérolek, Tarnardi, Nróik y Tsháiek.

Ante la imposibilidad de poder obtener descripciones valederas de los rasgos físicos de los Takshik, Lehmann-Nitsche dedicó sus esfuerzos a conseguir "fotografías de las fisonomías" enfatizando, tal vez en forma un poco exagerada debido a las dificultades que tuvo para realizar mediciones, el valor de esta clase de imágenes:

\footnotetext{
${ }^{26}$ La determinación de las identidades pudo realizarse cotejando, mediante la utilización de software digital (Adobe Photoshop CS3), los retratos de frente y perfil de estas mujeres con el retrato grupal. Estas imágenes digitales fueron consultadas en el Archivo Histórico y Fotográfico del Museo de La Plata.
} 
"Nos apresuramos a fijar lo antes posible todos nuestros sujetos sobre la placa fotográfica. La mejor descripción es sólo un sucedáneo insuficiente, cuando una representación figurada del individuo falta. Gracias a la complacencia del Sr. C. Bruch, que quiso encargarse de fotografiar a nuestros personajes en condiciones poco agradables, disponemos de un álbum antropológico que reproducimos sobre las planchas que acompañan este informe. Nos consolamos así de no haber podido estudiar muy a fondo a cada individuo en particular." (Lehmann-Nitsche 1904a: 270, mi traducción)

Además de las limitaciones impuestas por las religiosas Lehmann-Nitsche halló también resistencia de parte de los mismos takshik. De las 23 personas que fotografió solo pudo tomar medidas antropométricas sobre 13 de ellas (Lehmann-Nitsche 1904: 304-307). Entre el grupo que no fue medido había tres niños menores de dos años ${ }^{27}$ y ocho mujeres. No dice Lehmann-Nitsche porque no midió a los niños, tal vez porque no fueran significativos para sus estudios, aunque es posible que esto se haya debido que, como señalamos más arriba, no estaba interesado en conocer el desarrollo sino registrar y comparar los tipos humanos adultos, aunque también es posible que hayan sido las mujeres quienes le prohibieron realizar esas mediciones.

En todo caso estos datos nos llevan a pensar que una de las ventajas que aportaba la fotografía a esta clase de investigaciones residía en que era uno de los instrumentos de registro menos intrusivos con que contaban los antropólogos. Tal como señala Nelia Dias tanto las mediciones efectuadas sobre los cuerpos, como la realización de máscaras faciales ${ }^{28}$ implicaban una acción directa sobre el cuerpo de los indígenas

\footnotetext{
${ }^{27}$ Una niña, Alolé, hija de Arailná, y dos varones, Lederaik, amamantado por Serainerlé, y Aiká, hijo de Huoronatá. En este punto es necesario aclarar que entre los 23 takshik que se encontraban en Buenos Aires había distintos lazos de parentesco. De acuerdo con los datos que suministra Lehmann-Nitsche pudimos reconstruir 6 grupos familiares que comprendían a 19 personas del total del grupo. El núcleo parental más extenso, por ejemplo, estaba conformado por 6 mujeres; dos de ellas eran hermanas, Pelokoná y Serailnerlé, los tres hijos de esta última, Huashkini, Koâssenâ y Lederaik y una sobrina de las primeras, Kaikaná.

${ }^{28}$ Esta práctica se continuó ejerciendo en antropología física argentina hasta bien entrado el siglo XX. En 1934 un empresario llevó a Buenos Aires un grupo de wichí para exhibirlos en una exposición, lo que finalmente no sucedió debido a la intervención de la Comisión Honoraria de Reducciónes de Indios que, sin embargo, permitió a José Imbelloni y Enrique Palavecino, dos antropólogos de la Universidad de Buenos Aires realizar estudios sobre ese
} 
mientras que la fotografía permanecía a cierta distancia (Dias 1994a: 44). Así, al comparar la fotografía como herramienta de registro en términos de costo-beneficio con estas otras técnicas vemos que ella llevaba una buena ventaja con respecto a las demás. Por ello se puede argumentar que el extendido uso de esta técnica entre los antropólogos que hacían estudios raciales haya tenido que ver con estas razones.

Por otra parte, y en comparación con el dibujo, mientras este se desenvuelve por el terreno de lo similar, la fotografía lo hacía en el dominio de lo real y de lo exacto, y en ese sentido era considerada más natural que las ilustraciones hechas a mano ya que eliminaba, aparentemente, toda intervención humana (Daston y Galison 1992, Dias 1994a). Al igual de lo que sucedía en otras disciplinas, los datos antropológicos se volvían más impersonales, yendo la objetividad a la par con la eliminación gradual del observador (Dias 1994a: 45).

Figura 5. "Takshík 19a". Metaigishé (C. Bruch, Buenos Aires, septiembre de 1899) (AHFMLP - ARQ-002-027-

0001)

“... esta es la mujer más complaciente y agradable de toda la tropa. Ella dio voluntariamente informaciones sobre todas las cosas y facilitó visiblemente el peritaje. Logró convencer a sus compañeras que en primer lugar se negaban a dejarse examinar y fotografiar. Debo a su amable carácter la mayor parte de los datos emitidos en mi introducción. Pude asegurar, por su boca, la comparación y el control del vocabulario Toba de Lafone." (Lehmann-Nitsche 1904a:300, mi traducción)

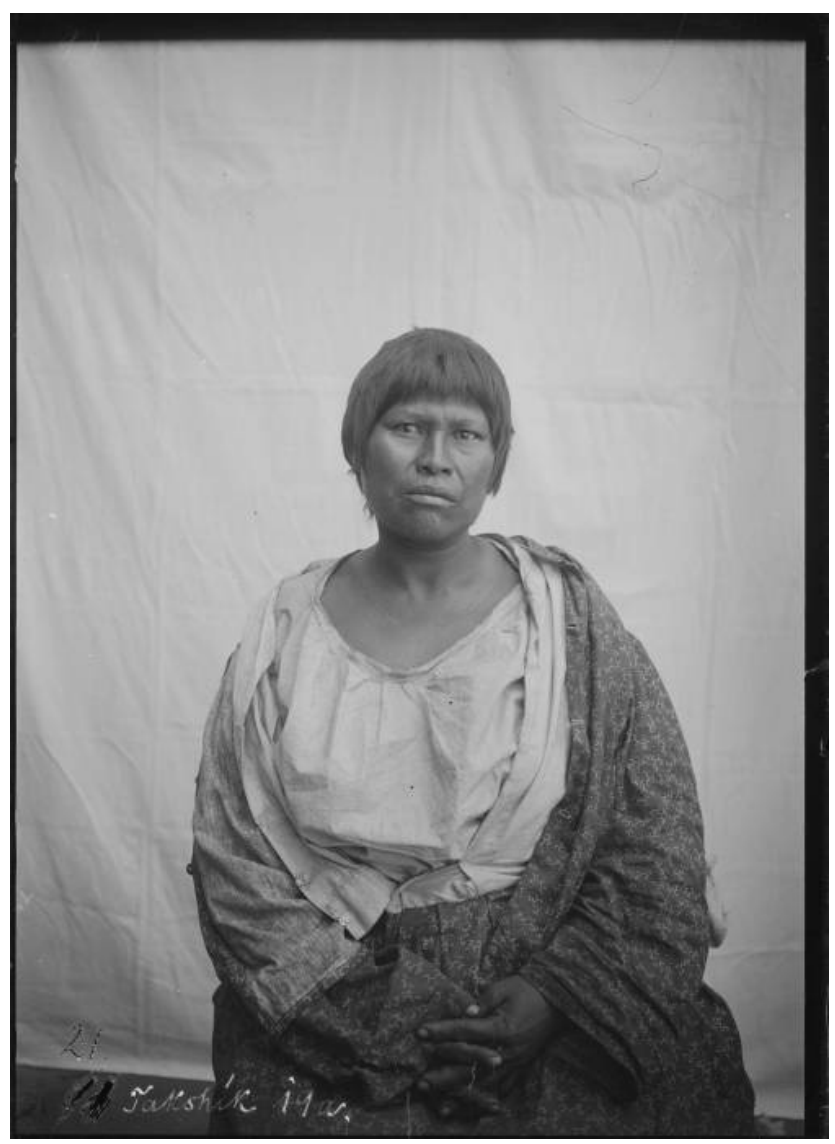

grupo. Tal como señala Gordillo mientras Palavecino tomó notas sobre el lenguaje, mitología y magia de los wichí, Imbelloni midió sus cuerpos y les realizó máscaras faciales (Gordillo 2006: 239) 
Además de la intermediación del "Viejo López", quien le había servido de intérprete, Lehmann-Nitsche contó con la colaboración de dos mujeres takshik, Metaigishé (Figura 5) y Kaikaná (Figura 6) gracias a quienes pudo convencer a otras mujeres quienes en un principio se había mostrado reticentes a ser medidas.

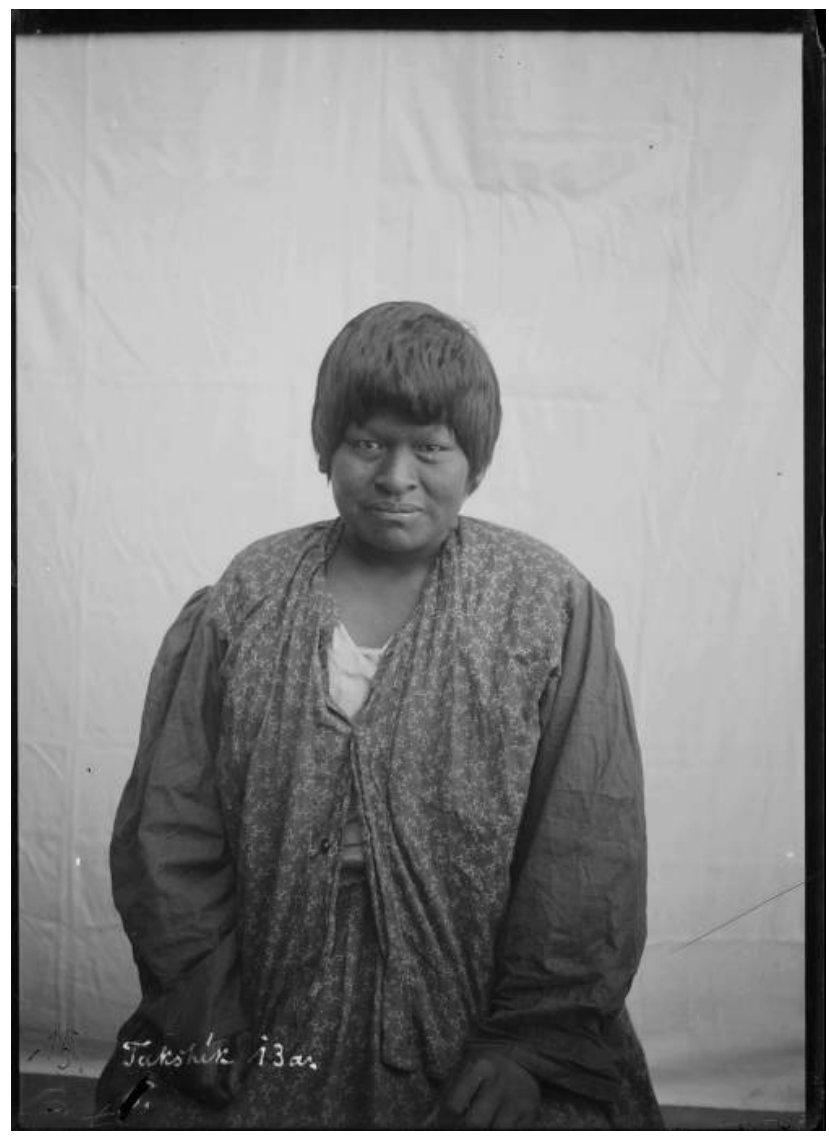

Figura 6. "Takshik 13 a" Kaikaná (C. Bruch, Buenos Aires, septiembre de 1899) (AHFMLP - ARQ-002-0240001)

"Casada; el marido se llama Hamôp, los dos hijos, niñas, Narôp y Nosoigenjé. Ningún otro niño se deriva de este matrimonio. El padre de Kaikaná, Teétrakié, y la madre Toietaraná viven en casa de su hija. Los padres de Teétrakié, Yarakatchigé (el padre) y Tsherlé (la madre) están todavía vivos, mientras que los de Toietaraná murieron. Una hermana de Kaikanâ se llama Napí. Todas estas personas se quedaron en Chaco. Kaikaná es una mujer fuerte, sólida y de buena apariencia; un poco grosera, de rasgos ordinarios; se parece en todo a una chica de granja. Amable, confiada, afable y servicial; ser agradable y apacible; me ayudó mucho a comprometer a sus compañeras cuando ponían dificultades para hacerse medir." (Lehmann-Nitsche 1904a: 290-291, mi traducción)

El intérprete que prestó su colaboración a Lehmann-Nitsche era conocido entre los estudiosos de los pueblos del Chaco y ya había colaborado con Samuel Lafone Quevedo en su vocabulario toba en 1888 (Lafone Quevedo 1899) ${ }^{29}$.

\footnotetext{
${ }^{29}$ Incluso este mismo intérprete colaboró con la Justicia en el interrogatorio a los takshik: "En ese acto se encontraba presente un intérprete Joaquín López, santiagueño, de 48 años, quien fue acompañado de su esposa, una indígena como de 45 años de la misma tribu de los asilados, y por intermedio de aquel fueron interrogados y dijeron llamarse: Narnaraayna, Cafiarapí, Metaichí, Jarday, Secuá, Nayray, Nognastá, Arayná, Pelocuná, Sarayché, Peloconá y Buauná. Estas son mujeres casadas y tres son solteras; todas ellas tienen esposos, hijos, padres y hermanos. Las indígenas han manifestado que han sido embarcados con engaño y en ausencia de sus esposos y padres; que ninguna ha manifestado el deseo de separarse de sus esposos y padres, y se lamentan de encontrarse lejos de ellos." La Nación 26/9/1899, pág. 6.
} 
Las mediaciones de las mujeres takshik y el lenguaraz que Lehmann-Nitsche utilizó para poder hacer sus estudios, resultan interesantes ya que a pesar de que los takshík estaban "retenidos", para la Justicia, o "prisioneros", para los medios de prensa, en cualquiera de ambos casos se hallaban participando de en una situación de poder desventajosa. Asimismo y si bien Lehmann-Nitsche y Bruch acudieron a estudiarlos con el visto bueno de la máxima autoridad judicial del país -el Ministro Osvaldo Magnasco-, esto no les garantizó que pudieran realizar su trabajo en la forma que pretendían, y para poder doblegar las voluntades de estas mujeres debieron apelar a su convencimiento, mediante la persuasión de sus pares. $\mathrm{Y}$, como ya vimos, en varios casos no lograron obtenerlo. Esta resistencia dificultó la investigación, influyendo sobres sus resultados, cosa que Lehmann-Nitsche se encargó de señalar en forma explícita al inicio de su trabajo. En este sentido, Pacheco de Oliveira (2006) nos llama la atención acerca de lo que él denomina la "auto-representación más habitual" de la antropología en el sentido que "el encuentro entre el "antropólogo" (siempre pensado como el "de afuera") y el "nativo" sólo ocurre por estar enmarcado en un cuadro colonial mayor, que prescribe conductas y representaciones diversas para cada uno de esos actores sociales, haciendo posible que se instaure una relación unilateral de investigación y producción de conocimiento." (Pacheco de Oliveira 2006: 206) De ese modo el hecho de que las mujeres takshik no se comportaran de acuerdo a esas "conductas prescriptas" nos muestra la posibilidad de que la "relación unilateral de investigación y producción de conocimiento" puesta en práctica por el investigador se vea obstaculizada, al menos en parte, por las reacciones de los investigados que no fueron siempre complacientes.

Esta limitación en las mediciones, sin embargo, no impidió que Lehmann-Nitsche efectuara una descripción de los rasgos físicos, especialmente de los rostros de las mujeres que se resistieron a ser medidas, recurriendo, nuevamente a las fotografías. Llama la atención que la descripción de esos rasgos se ofrecía en un mismo párrafo junto con algunas apreciaciones acerca del carácter o personalidad de las personas descriptas. 
En este sentido, cabe recordar que la creencia de que la variabilidad de tipos humanos podía interpretarse en términos de sus diferencias físicas tomó muchas formas y un camino importante fue la teoría de la "fisiognomía" ${ }^{30}$, que suponía que la estructura física y apariencia exterior del rostro era un indicador de los rasgos morales y culturales internos (Street 1990: 11-12). Esto, como vimos para el caso de Amadeo Bezzi, también tuvo una aplicación en la criminalística ya que se suponía que los rasgos faciales podían se además indicadores de supuestas tendencias criminales. Sin embargo, Lehmann-Nitsche no señala que estas afirmaciones sobre el carácter de los retratados hayan sido inferidas a partir de sus rasgos fisonómicos, y no parece que ese sea el caso ya que, por ejemplo, en la descripción que ofrece sobre Kaikaná (Figura 6) dice por un lado que ella tenía "rasgos ordinarios" afirmando más adelante que se trataba de un "ser agradable y apacible" (Lehmann-Nitsche 1904: 291). Parece más probable, a juzgar por nuestros datos, que los juicios de Lehmann-Nitsche acerca del carácter de estas mujeres y hombres hayan sido emitidos en base a las impresiones que tuvo al estar en contacto con este grupo, y no a partir de una "lectura de sus rostros".

\footnotetext{
${ }^{30}$ Este término refiere a la idea de que a partir del estudio de apariencia externa de una persona, especialmente de su rostro, puede conocerse su carácter o personalidad. El religioso suizo de habla alemana Johan Caspar Lavater (1741-1801), considerado fundador de esta disciplina, sostenía que un fisiognomista avezado podía leer el carácter humano a partir del semblante y su correcta representación gráfica (Stemmler 1993: 115) El término fisonomía, en cambio, tiene un sentido más restringido, refiriéndose al aspecto particular del rostro de una persona.
} 


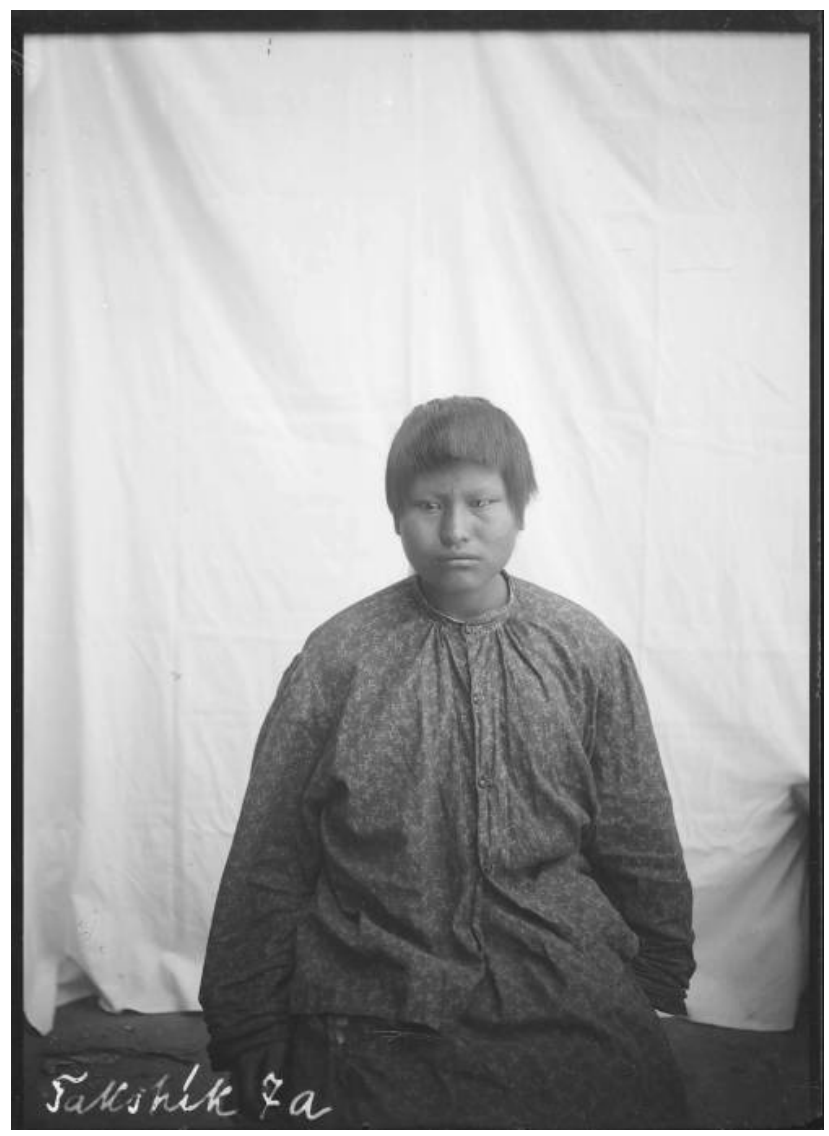

Figura 7. "Takshik 7a" Palagishí. (C. Bruch, Buenos Aires, septiembre de 1899) (AHFMLP - ARQ-002-0240005)

"Hija de Kapieré (número 17), de diecisiete años de edad. Bien desarrollada, fuerte; ser huraño y poco simpático; batalladora; había tenido una disputa violenta con otra de las jóvenes hijas y los rastros de arañazos en la frente, en que eso había resultado, no habían cicatrizado aún cuando la fotografié". (Lehmann-Nitsche 1904a: 281)

\section{La "Fotografía Antropológica" y las recomendaciones de la Escuela de Antropología de Paris.}

Refiriéndose a los métodos y técnicas que había utilizado en su estudio, LehmannNitsche señala que se basó, para la toma de la fotografías, en el método propuesto en el $N^{\circ} 8$ de la Revue Mensuelle de l'Escole d'Anthropologie de Paris (1898). Allí se publicó una comunicación titulada "Photographies Anthropologiques", dividida en cuatro secciones que presentaban los resultados de los estudios hechos por una comisión formada entre otros por los antropólogos Gabriel de Mortillet (1821-1898), Léonce Manouvrier (1850-1927) y el fotógrafo Edouard Fourdrignier (1842-1907), para representar por medio de un ejemplo práctico una rigurosa propuesta para aplicar la fotografía a los estudios antropológicos. 
La primera sección, además de introducir al tema tratado presentaba algunas aseveraciones sobre el desnudo en la fotografía antropológica. En esta primera parte, Mortillet quien era también profesor de Antropología Prehistórica de la Escuela de Antropología de Paris desde 1876 (Cfr. Podgorny 2009), hacía un vehemente alegato a favor de los retratos al desnudo para fines científicos,

"Si un naturalista fuera a describir, a fotografiar y a dibujar a los animales del teatro Corvi con los trajes de general, de gran dama, de criado, de confidenta, etc., con que se los atavía, usted se encogería de hombros exclamándole: - ¡Esto no es serio!" (Mortillet 1898: 105)

Esta era para Mortillet una situación cotidiana en la antropología de esos días, que para estudiar a una persona fotografiaba "más trajes que partes descubiertas", lo que volvía al método de la fotografía antropológica "ridículo y vicioso" y necesitaba cambiar. Así Mortillet afirma que para estudiar al hombre había que fotografiarlo desnudo, del mismo modo que lo exigía el arte, "Es este desnudo lo que reclamamos para la antropología. Pedimos que la ciencia sea asemejada lisa y llanamente al arte." (Mortillet 1898: 105, mi traducción)

Sin embargo el acercamiento que Mortillet planteaba entre arte y antropología se circunscribía a la posibilidad de representar cuerpos desnudos para su estudio, ya que la antropología necesitaba de "informaciones precisas y comparables" por lo que "Todo movimiento, toda animación -tan buscados por el arte- son perjudiciales para la antropología. El desnudo de la ciencia debe quedar frío e inmovilizarse en posturas simples, siempre los mismos." (Mortillet 1898: 106, mi traducción) La fotografía de desnudos para fines científicos chocaba además, con otra dificultad, la de conseguir individuos que consintieran fotografiarse sin sus ropas, que como vimos en el parágrafo anterior podía hacer peligrar el éxito de las investigaciones. Para resolver este problema Mortillet proponía, para el caso de los hombres, buscar posibles candidatos entre los reservistas del ejército donde él mismo los había conseguido. En cuanto a las 
mujeres declaraba que no había tenido mayores dificultades aunque no queda claro como logró sus modelos, sobre todo teniendo en cuenta que había dejado de lado a las prostitutas, cuyos caracteres se encuentran "frecuentemente debilitados y modificados" además de la dificultad que representa establecer su procedencia y su edad (Mortillet 1898: 106). Sin embargo Mortillet dejaba sin resolver la cuestión de cómo conseguir la colaboración de los retratados cuando los estudios se hacían sobre pueblos indígenas.

La fotografía antropológica que proponía Mortillet implicaba ubicar a los sujetos de forma rigurosamente pautada. Los individuos debían ser retratados de pie con las piernas juntas y brazos colgando a ambos lados del cuerpo, mientras que las tomas debían hacerse desde tres puntos de vista diferentes; "perfectamente de frente", "netamente de perfil" y "de plena espalda" (Figura 8). Alrededor de dos décadas antes de que Mortillet definiera estas pautas, el antropólogo inglés Thomas Huxley había desarrollado un método para la fotografía antropológica que era en cierto modo similar (Cfr. Spencer 1992). Sin embargo, según señala el autor francés, este tenía varios defectos; las placas utilizadas eran muy pequeñas, se descuidó la vista de espaldas, y se complicaron las posiciones debido a los movimientos de los brazos que tapaban ciertas partes del cuerpo (Mortillet 1898:107).

Si bien a partir de esta serie de reglas para la fotografía se podría entonces dar clara cuenta de todos los caracteres de una persona, para que estas "academias" verdaderamente útiles y prácticas debían ser tomadas en posturas predeterminadas y según escalas exactamente semejantes, sin importar el lugar o quien las tome. A esta unidad de posturas y escalas había que agregar además una regla graduada que iría ubicada a un lado del sujeto retratado y cuyo uso, a pesar de no brindar datos absolutamente exactos, resultaría ventajoso. (Mortillet 1898: 107) (Figura 8)

\footnotetext{
${ }^{31}$ Este es el término utilizado por Mortillet para referirse a las fotografías de desnudos, un término que está vinculado originalmente al arte, especialmente a la pintura, y no tanto a la fotografía. Según el Diccionario de la Real Academia Española las academias son estudios de una figura entera y desnuda, tomada del natural y que no forma parte de una composición.
} 

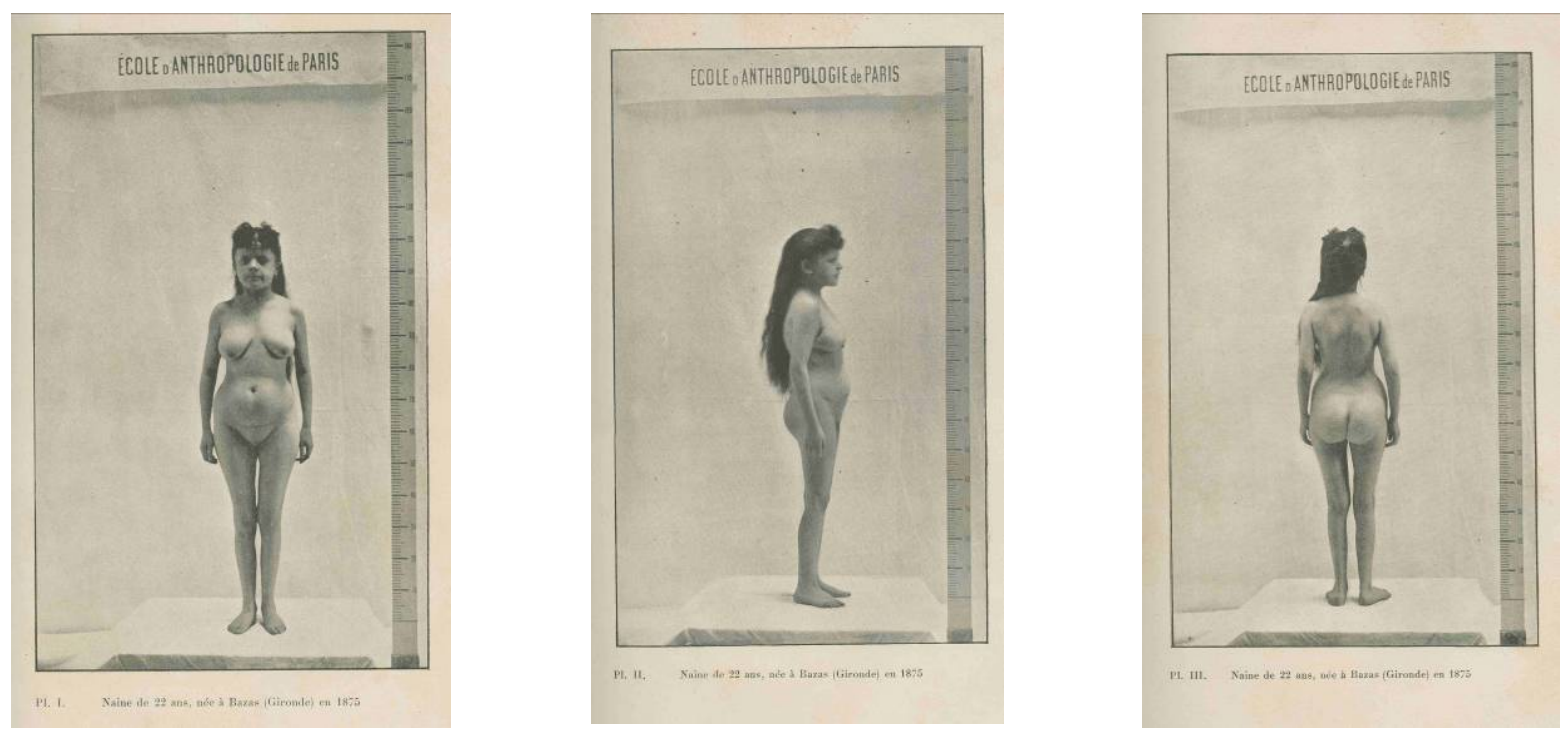

Figura 8. Revue Mensuelle de I’Ecole d'Anthropologie de Paris, 1898, 8. PI. I, II y III.

La segunda parte de esta comunicación estuvo a cargo de Edouard Fourdrignier, quien se ocuparía de las especificaciones técnicas necesarias para lograr una "Unidad Fotográfica". Comenzaba Fourdrignier señalando que hasta ese momento las fotografías antropológicas se realizaban sin una escala proporcional, cosa que dificultaba las comparaciones ya que cada investigador uno actuaba a su modo. Por ello al comparar estas fotografías resultaba difícil dar cuenta de las diferencias de tallas y de proporciones. Hacía falta, según Fourdrignier, crear un punto de referencia.

El problema que se planteaba era obtener la fotografía de una persona cuya imagen pudiera ser reducida conforme a una escala proporcional determinada y constante. Seguidamente a ello sugería algunas fórmulas para tomar fotografías con una escala fija mediante la cual, a partir de las medidas del negativo fotográfico, se podrían determinar las medidas de la persona allí representada. Estas fórmulas estaban calculadas en base a un negativo de $13 \times 18 \mathrm{~cm}$., para cuyas dimensiones recomendaba adoptar dos escalas constantes, una para las fotografías de pie y otra para las fotografías de detalles o de alguna parte específica del cuerpo (Fourdrignier 1898: 108-110) 

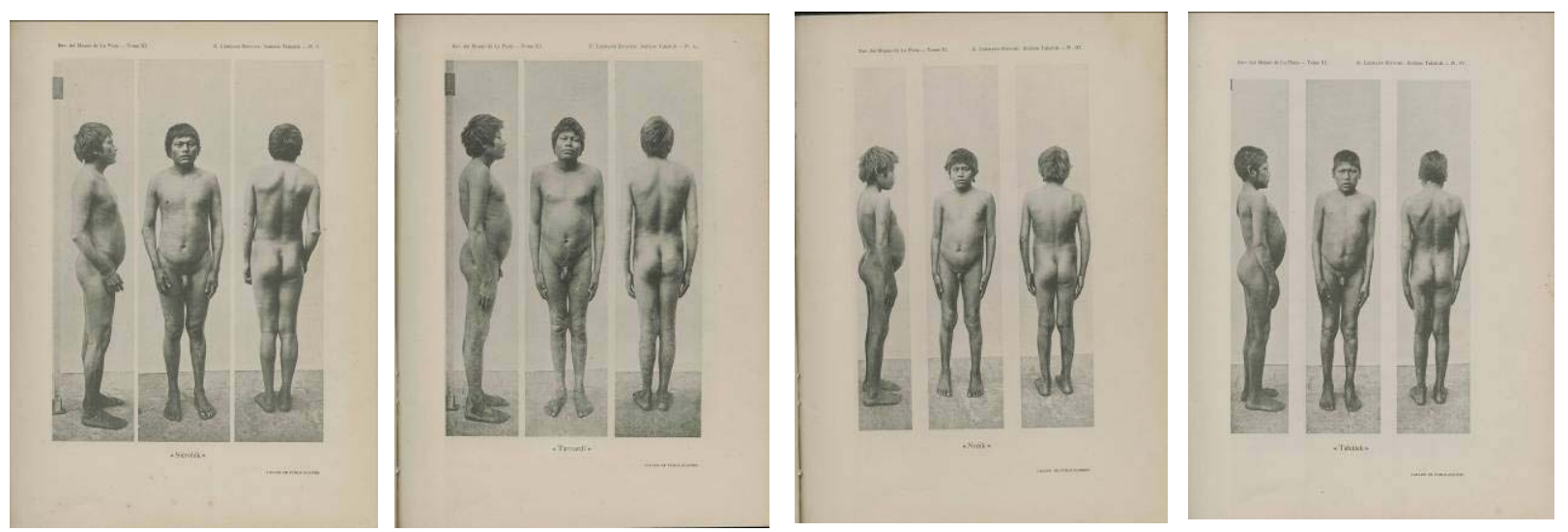

Figura 9. Revista Museo de La Plata, T. XI, 1904, PI. I “Siérolék”, PI. II “Tarnardí”, PI. III “Nróik”, PI. IV “Tsháiek”.

Lehmann-Nitsche tuvo la intención de aplicar este método fotográfico cuando realizó su trabajo entre los takshik, tal como podemos suponer si tenemos en cuenta que siguió los consejos de Mortillet y Fourdrignier en todos los puntos. Así, tomó todas las fotografías en placas de vidrio de $13 \times 18 \mathrm{~cm}$. y a una misma escala. Además, en los casos de dos hombres jóvenes y dos adolescentes pudo hacer fotos de desnudos, en cuerpo entero, de frente, de perfil y de espaldas ${ }^{32}$, incluyendo en la imagen una escala métrica, tal como plantearon los antropólogos de la Escuela de Paris (Figura 9). Sin embargo, tal como señalamos, las dificultades que enfrentó no le permitieron contar con varones adultos por un lado, y tampoco pudo tomar fotografías de desnudos a las mujeres, lo que lo obligó a conformarse con fotografiarlas de busto en dos posturas, de frente y de perfil.

\section{El "método" de Gustav Fritsch.}

En el segundo semestre de 1900, un año después de haber hecho las mediciones y fotografías sobre los takshik, Lehmann-Nitsche realizó un viaje a Europa llevando a cabo una serie de distintas actividades académicas. En Alemania visitó entre otros a Adolf Bastian (1826-1905), director del Museo Etnográfico; a Voss, director del Museo

\footnotetext{
${ }^{32}$ Si bien debemos notar, como puede verse en la Figura 9, que este orden fue ligeramente invertido por LehmannNitsche cuando publicó las fotografías, colocando en primer lugar la imagen de perfil, luego la de frente y finalmente sí la de espaldas. Además, imprimió las tres fotografías de la misma persona en una sola plancha y no en planchas separadas, tal como se proponía en la Figura 8.
} 
Prehistórico, también a Karl von den Steinen y Paul Ehrenreich. Asistió a una conferencia sobre etnografía que dictó Bastian en la Universidad de Berlin, concurrió al congreso de la Sociedad Antropológica Alemana donde se encontró con Rudolf Virchow, Ranke entre otros renombrados antropólogos de ese entonces. Estando en Paris dio una conferencia sobre los takshik en el Congreso de Americanistas. Una de sus preocupaciones durante este viaje fue la de perfeccionar los instrumentos y procedimientos relacionados con la fotografía antropológica,

"Mi trabajo principal era dedicado a la construcción de aparatos antropológicos. En el estudio de los patagones y los Takshik en B[uenos] Aires, noté la deficiencia de los aparatos empleados. En cuanto a la antropometría hice construir en una casa especial un nuevo aparato según mis indicaciones. Para la fotografía antropológica obtuve no solamente los instrumentos mejor construidos actualmente, sino que modifiqué también el de Bertillon, simplificándolo para los viajes. Creo que será la primera vez que se emplean los aparatos de Bertillon para el estudio de la Antropología."33

Visitando además el laboratorio de Josef Szombathy en el Museo de Viena, donde conoció el procedimiento por el cual se fotografiaban y medían 15 personas por día ${ }^{34}$. Pero sin duda la más significativa de sus actividades en el campo de la fotografía fue la visita que realizó estando en Berlin al antropólogo Gustav Fritsch (1838-1927) quien era, de acuerdo con Zimmerman "uno de los mayores promotores de la fotografía antropológica" (Zimmermann 2003:162). La capacidad de Fritsch con la cámara había sido reconocida desde al menos 1869, cuando participó como fotógrafo en una expedición astronómica a Aden. Debido en parte a la ventajas de tener un fotógrafo experimentado entre su personal la facultad de Medicina de la Universidad de Berlín lo contrató como conferencista en anatomía en 1872. Fritsch esperaba que la fotografía pudiera comprobar las inexactitudes que el dibujo había introducido en las representaciones de los primeros antropólogos como Blumenbach. El pronosticó que la fotografía contribuiría a liberar a las representaciones científicas de las distorsiones

\footnotetext{
33 "Informe del viaje a Europa realizado en 1900" (R. Lehmann-Nitsche 1901, AHPBA)

${ }^{34}$ Ibid. ant.
} 
arbitrarias encontradas en el arte y en el dibujo a mano alzada (Zimmerman 2001: 398). De esa manera las fotografías podían servir de correctivo a la concepción personal en las mejores representaciones realizadas por una mano artística, y sólo ellas permitirían una comparación segura (Fritsch 2006b [1874]: 58).

Al igual que Huxley en Inglaterra, y Mortillet y Fourdrignier en Francia, Fritsch había propuesto, hacia mediados de la década de 1870, una serie de reglas "científicas" sobre la fotografía antropológica ${ }^{35}$ para los viajeros, entendiendo que la estandarización de ese proceso contribuiría a la medición de las proporciones humanas y la creación de una base de datos para la comparación de los "tipos" humanos, afirmando que la fotografía podría brindar la evidencia científica necesaria para los antropólogos (Lewerentz 2008: 153) Para Fritsch las fotografías podían ofrecer datos comparables siempre y cuando se tomen con el mismo objetivo y a la misma distancia de forma que la perspectiva influya sobre ellas de igual manera (Fritsch 2006a [1870]: 55)

Sin embargo este autor no confiaba ciegamente en el procedimiento fotográfico sino que, por el contario, entendía que por más exactas que pudieran ser las imágenes fotográficas ellas proporcionaban un exceso de detalles superfluos, lo cual resultaba un inconveniente, ya que mostraba las diferencias de color en los objetos de la misma manera que mostraba las sombras. Aunque estos inconvenientes podían ser superados rápidamente a través del aprendizaje y por intermedio del hábito que permiten "ver correctamente las imágenes para eliminar en ellas lo que estorba" (Fritsch 2006a [1870]: 57).

\footnotetext{
${ }^{35}$ Las detalladas instrucciones de Huxley y Fritsch se anticipan al menos en una década a los principios enunciados por el funcionario policial francés Alphonse Bertillon (1853-1914) en cuanto al uso de los retratos fotográficos en la antropometría.
} 


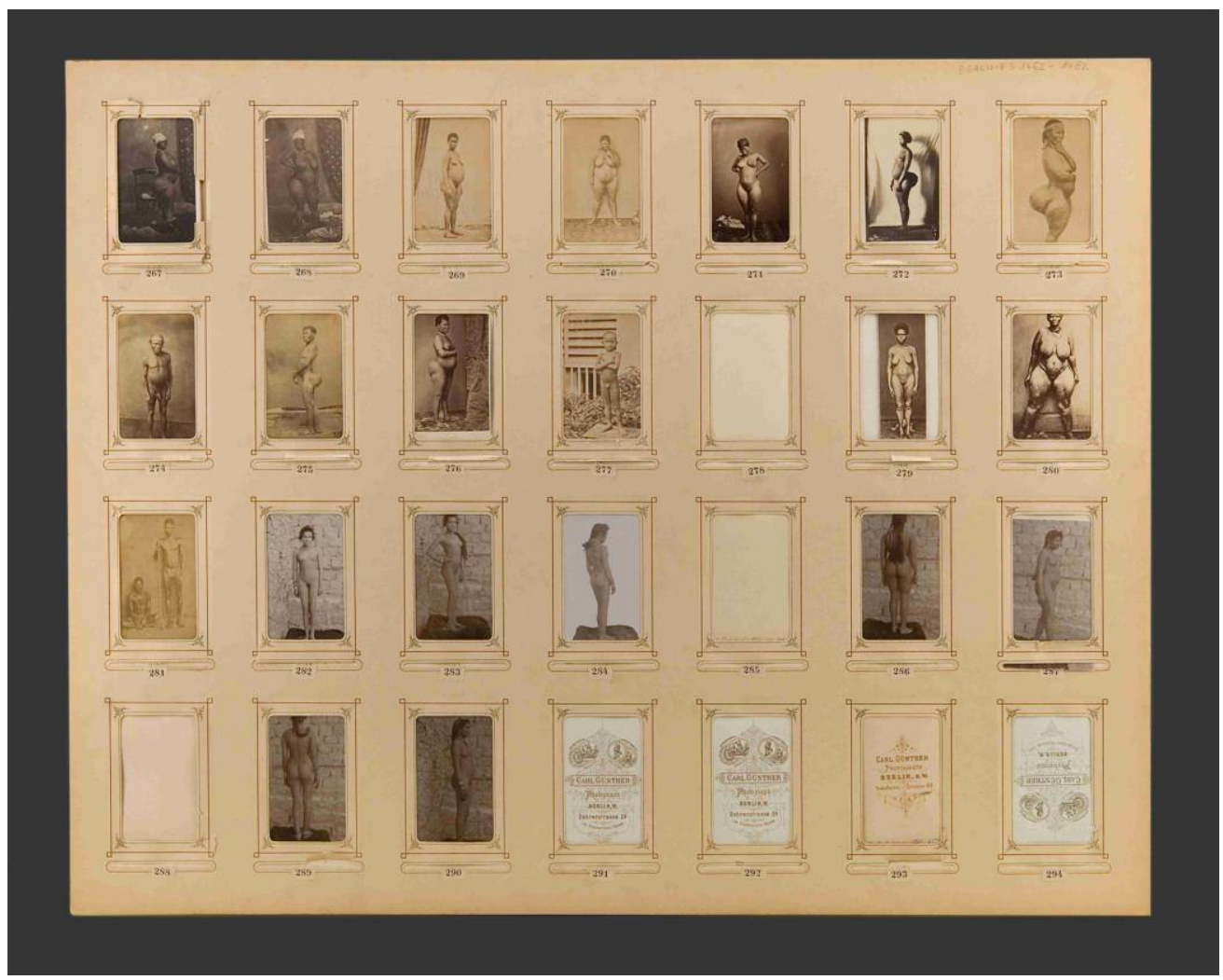

Figura 10. Album fotográfico, Gustav Fritsch (BGEAU-FS 1462-1482)

El énfasis puesto por Fritsch en los estrictos principios que habrían de seguirse para tomar retratos de desnudos -particularmente de "razas" no europeas- en la década de 1870, iría modificándose hacia finales de siglo. En efecto, como señala Lewerentz (2008), para esa época, el énfasis de Fritsch acerca del uso de la fotografía en antropología iría cambiando desde lo científico a lo estético, expresándose en un lenguaje de proporciones ideales y "belleza racial". En ese sentido la mayoría de las fotografías de desnudos tomadas por él mismo, así como aquellas obtenidas de otras fuentes no cumplían con los estándares que él mismo había establecido dos décadas antes, incluso sus fotografías de desnudos observaban poses construidas artificialmente (Figura 10) (Lewerentz 2008: 152-156). Por otra parte, al igual que el célebre científico inglés Francis Galton (1822-1911) quien no utilizaba, para sus retratos compuestos fotografías de similares características sino que las seleccionaba, Fritsch hacía extrapolaciones de un conjunto de individuos selectos para definir los tipos a los cuales esos individuos se suponía que pertenecían (Broeckmann 2008: 
148). Tal como podemos observar en la Figura 10, las fotografías que Fritsch dispuso en ese álbum se corresponden con el formato denominado carte de visite ${ }^{36}$.

A inicios de la década de 1890 Fritsch había desarrollado lo que él mismo denominaba "canon de proporciones" (Fritsch 1893), y que utilizaba como criterio para comparar las proporciones anatómicas de los diferentes grupos raciales. Este canon estaba basado en una teoría de las proporciones que se derivaba de la escultura antigua y que había sido enunciada en primer lugar por Policleto (480 a.C.- 420 a.C.), escultor griego del período clásico. Con la ayuda de esta teoría, Fritsch definió el "cuerpo blanco ideal". En ese sentido, el canon de proporciones era un concepto eurocéntrico, en tanto Fritsch lo utilizaba para ilustrar la teoría que sostenía que la "raza blanca", en sus proporciones corporales, era la que más se acercaba al "ideal anatómico". Un estado casi perfecto de desarrollo físico que tenía su contraparte en el progreso cultural. Por otro lado, el canon de proporciones tenía un carácter "abstracto" en comparación con las mediciones corporales y Fritsch lo consideraba como el instrumento "más científico" para la clasificación racial, entendiendo que la antropometría se hallaba "abrumada por los números". Por ello alegaba que las fotografías, al ser observadas en los términos de este canon eran el medio más útil para examinar la diferencia racial (Lewerentz 2008: 153-157).

Los argumentos de Fritsch tuvieron una gran influencia en las decisiones tomadas por Lehmann-Nitsche al publicar su trabajo sobre los takshik, quien organizó parte del atlas antropológico de 1904 siguiendo sus consejos (Figuras 11, 12 y 13),

"Dispusimos nuestros individuos sobre las planchas según un método que nos hizo saber el Sr. Fritsch en Berlín, el cual arregló así su magnífica colección de fotografías antropológicas. El principio es ofrecer a la vista de la persona que las considera el más

\footnotetext{
${ }^{36}$ Las cartes de visite eran fotografías impresas en papel de pequeño tamaño, hechas a partir de negativos de vidrio y luego pegadas sobre cartón, de donde se podían obtener ocho retratos idénticos en una misma plancha. Tuvieron su apogeo en las décadas de 1860 y 1870 . Debido al tamaño compacto y a la facilidad de reproducción de esta clase de formato fotográfico, su costo se redujo bastante en comparación con otros soportes como el daguerrotipo, permitiendo que casi cualquier persona de la clase media pudiera adquirir un conjunto de esos pequeños retratos que eran ofrecidos en los comercios fotográficos (Bauret 1999; Long 2003)
} 
grande número posible de fotografías sobre una sola plancha. El ojo no se cansa así y no se "hipnotiza", tal como se expresa el Sr. Fritsch. Una sola ojeada basta para mirar a un gran número de individuos a la vez. El ojo mismo se hace así una media fotográfica de todos los sujetos reunidos..." (Lehmann-Nitsche 1904: 272)

Sin embargo como podemos en las tres siguientes figuras, la disposición de las fotografías no conservaban un patrón determinado. Por ejemplo en la Figura 11 (PI. V), si "leemos" la plancha en el mismo sentido que un texto escrito, o sea de arriba abajo y de izquierda a derecha podemos distinguir tres "renglones" o líneas de imágenes, con cuatro fotos cada una. En la primera línea las fotografías se suceden en el siguiente orden: perfil-frente-perfil-frente. La segunda línea esta arreglada en forma inversa a la primera, o sea: frente-perfil-frente-perfil. Finalmente, la última línea repite el patrón de la primera.

En la Figura 12 (PI. VI) tenemos un ordenamiento diferente pero más sencillo que el de la figura anterior, ya que los tres renglones respetan el mismo orden: frente-perfilfrente-perfil.

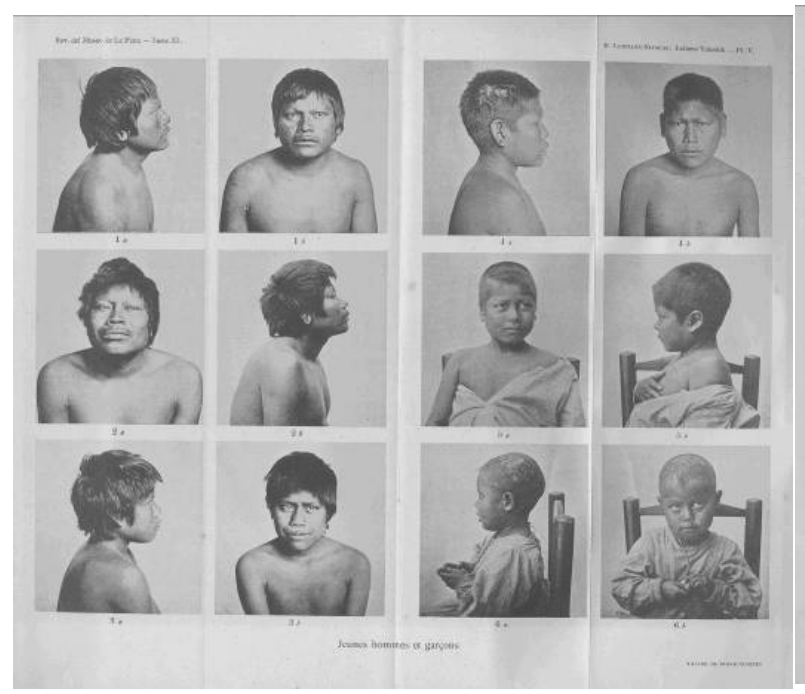

Figura 11. „Jeunes hommes et garcons» (Lehmann-Nitsche 1904a, PI. V)

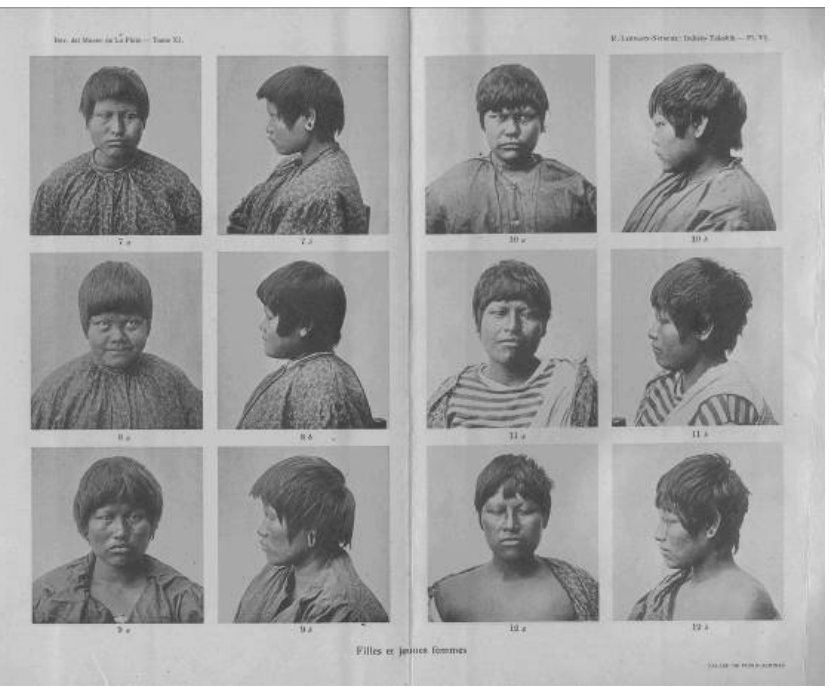

Figura 12. „Filles te jeunes femmes" (Lehmann-Nitsche 1904a, PI. VI) 
Finalmente la Figura 13 (PI. VII) difiere de las demás en dos aspectos. En primer lugar incluye seis imágenes más que las planchas anteriores (dos más por cada línea). Luego, esas líneas de fotografías presentan una disposición que no se deja encasillar en ningún patrón análogo a los de las anteriores planchas, incluso las dos fotografías que aparecen en el extremo inferior derecho de la plancha no pueden considerarse de la misma clase que las demás, ya que no se trata de retratos individuales, sino que representan a dos personas distintas cada una. Además una de ellas, la primera empezando desde la izquierda, fue recortada de la foto grupal tomada en el patio del Asilo del Buen Pastor (ver Figura 4). En tanto que la foto que le sigue no deja ver claramente el rostro de la mujer que observa al bebé apoyado en su regazo.

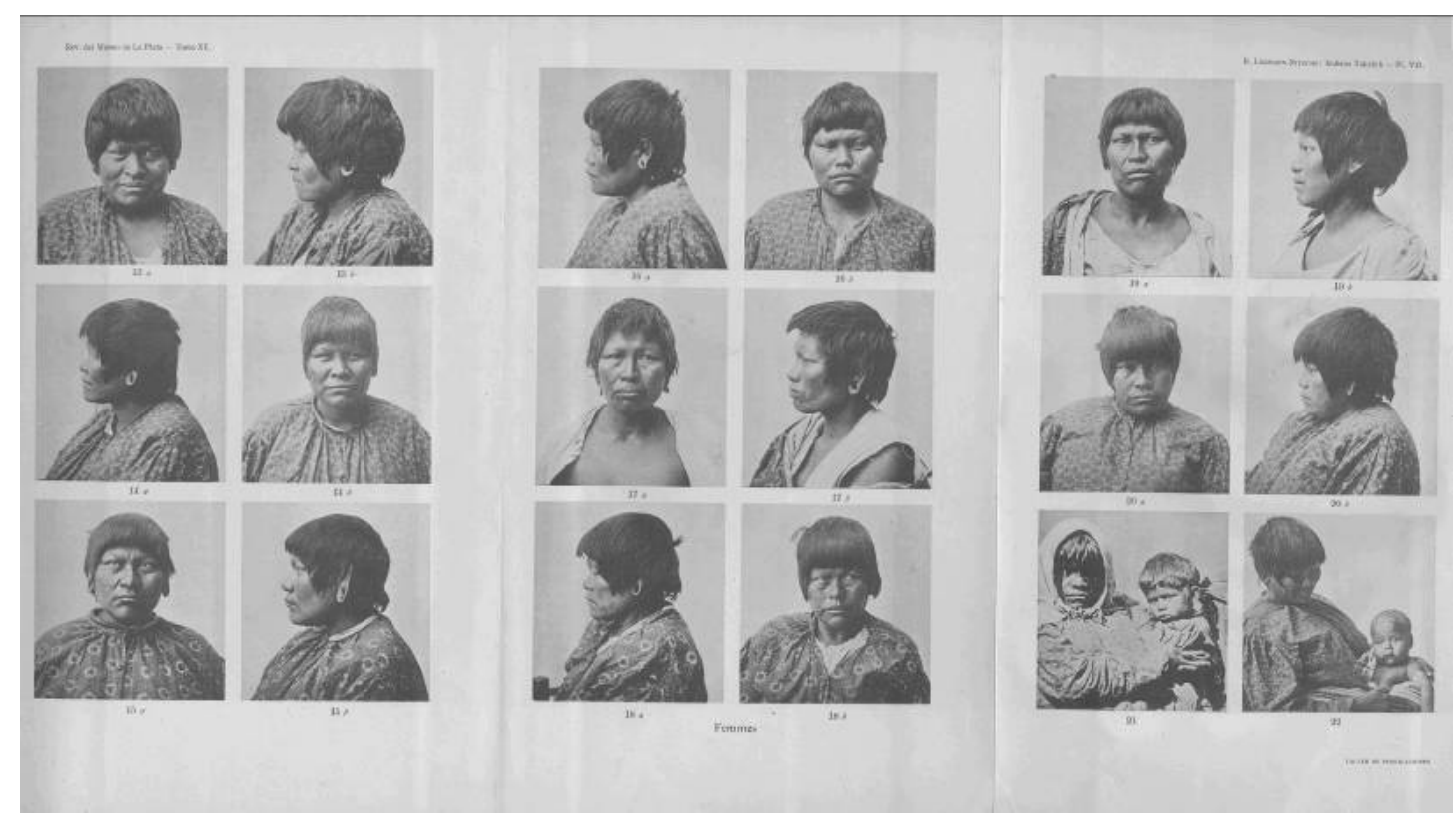

Figura 13. "Femmes" (Lehmann-Nitsche 1904a, PI. VII)

Todas estas consideraciones, aunque puedan aparecer un poco engorrosas, nos permiten comprender que el "método" que Fritsch le transmitió a Lehmann-Nitsche era de una sorprendente sencillez ya que sólo exigía, literalmente, "ofrecer a la vista de la persona que las considera el más grande número posible de fotografías sobre una sola plancha". Estas fotografías, como vimos en los ejemplos anteriores, no tenían que estar dispuestas de acuerdo a ningún ordenamiento lógico e incluso, observando las imágenes en la Figura 10, veremos que ellas podían no respetar ninguna de las 
detalladas reglas de la fotografía antropológica ${ }^{37}$ que el mismo Fritsch había enunciado ${ }^{38}$.

En un trabajo posterior Lehmann-Nitsche sostenía que:

"Según los conceptos de la biología moderna - y la genealogía moderna en ciencias biológicas - un individuo no es un objeto aislado, único, sino parte de un conjunto más o menos numeroso (la familia, el linaje) cuyos caracteres típicos representan con mayor o menor intensidad, ya acercándose, ya alejándose de un término medio ideal. El tipo término medio de un linaje, se nos presenta ante nuestra fantasía, después de la inspección de muchos retratos o de los individuos mismos de esa familia; notamos al mismo tiempo, que ninguno de todos los componentes individuales, es absolutamente idéntico a aquel término medio ideal. Según nuestro modo de ver, basta la concepción psíquica de ese tipo medio" (Lehmann-Nitsche 1919: 88-89)

La determinación de los tipos raciales era una preocupación ampliamente extendida entre los antropólogos de finales del siglo XIX. El conocimiento de la especie humana solo podía realizarse a partir de la comparación entre sus diferentes razas, de modo que la construcción de información en forma sistemática y controlada de estas razas era una necesidad para poder obtener resultados científicamente confiables, esto es, poder realizar comparaciones a escala global. Este proyecto científico alentó mucha de la investigación entre los antropólogos de ese entonces cuando varios procedimientos fueron ideados para traducir en términos comparables las observaciones y los registros gráficos realizados de los investigadores, como vimos en este capítulo.

\footnotetext{
${ }^{37}$ En la Figura 10 vemos que los fondos sobre los que se hicieron los retratos no son homogéneos, las posturas de los retratados no están pautadas, no se respeta una misma escala para la fotografía, etc. Todo ello con motivo de que esa plancha se llenó con cartes de visite comercializadas en las comercios fotográficos, y como tales no respetaban ninguna de las reglas de la fotografía antropológica y solo buscaban responder a los gustos del mercado. ${ }^{38}$ Sin embargo, esta aparente ausencia de lógica en el ordenamiento de las imágenes, que parecen haber sido dispuestas al azar, podría haber sido hecha en forma intencional. Al no permitir que el ojo identifique una regularidad en esa disposición, es posible que se haya intentado conseguir que las imágenes dieran una impresión de "movimiento" con el fin de dar cierta "naturalidad" a lo observado. Veremos esto con más detalle en el capitulo siguiente.
} 
Sin embargo, prestando atención a nuestra descripción acerca de los procedimientos visuales utilizados por Lehmann-Nitsche, basado en los principios de Gustav Fritsch, vemos que se esperaba que con sólo disponer una serie de fotografías sobre una cartulina de determinada forma alcanzaría para que el ojo, con un golpe de vista, capturase la esencia común de los retratos y fuera capaz de visualizar el tipo característico del grupo fotografiado. En este sentido y a diferencia de aquellos científicos que buscaban diseñar el instrumento que les permita construir datos objetivos y confiables, el énfasis no estaba puesto en la fiabilidad depositada en el instrumento, no se trataba de una "objetividad mecánica", sino que dependía fundamentalmente del entrenamiento y la experiencia del observador. Tal como señala Daston todas estas técnicas tenían como fin mucho más que visible lo invisible, ellas aspiraban a la condensación de laboriosos procedimientos en un coup d'oeil inmediato (Daston 2008: 108)

De este modo la utilización del procedimiento ideado por Fritsch permitía al ojo avezado capturar de una mirada el tipo físico de una "raza", lo que resultaba sencillo, económico y rápido, haciendo innecesario fotografiar a un individuo sobre una placa ya ocupada por el retrato de otro, procedimiento propuesto por el fotógrafo francés Arthur Batut (Lehmann-Nitsche 1904: 272), y que no era otra cosa que la traducción al francés del procedimiento de los retratos compuestos diseñado por Francis Galton y Herbert Spencer $^{39}$. No era necesario recurrir a ningún artificio químico o mecánico para lograr combinar todas la variables visuales en juego, bastaba solo con disponer las fotografías de un grupo determinado de individuos sobre una misma plancha o lámina para que el ojo pueda sintetizar todas esas imágenes en una sola; logrando así un promedio visual, extrayendo el "tipo racial" de esa maraña de retratos mediante la sola acción de un

\footnotetext{
${ }^{39}$ Así describía Lehmann-Nitsche este procedimiento: "Galson [SIC] en 1878 y Batut en 1887 dividieron el tiempo de exposición de una placa fotográfica, en tantas fracciones cuantos miembros de la familia a examinar; sobre una y la misma placa, fue expuesto después, sucesivamente, cada uno de los individuos o de sus fotografías, pero sólo durante el breve intervalo de tiempo que fue calculado al principio. Estaban, pues, al fin, expuestas sobre las mismas placas, las cabezas de todos los miembros de una familia, una sobre la otra, correspondiendo el conjunto de las exposiciones sucesivas, al tiempo de una exposición normal. El retrato compuesto, obtenido de tal manera, reúne materialmente los caracteres individuales de cada caso; es desde luego, difuso y dudamos si el trabajo empleado para su realización, corresponde al éxito." (Lehmann-Nitsche 1919: 89)
} 
golpe de vista. Generando orden a partir del caos mediante por intermedio del entrenamiento y la experiencia.

A esta altura podría dudarse del valor científico de esta clase de procedimientos, de los cuales podría decirse que dependen completamente de la experiencia individual o que no son susceptibles de repetirse por otros observadores. Sin embargo es pertinente traer a cuento lo señalado por Lorraine Daston que en un ensayo reciente se ocupa en conocer como la observación experta discierne y estabiliza objetos científicos para una comunidad de investigadores. Así esta autora señala que sin estos hábitos adquiridos de percepción, cultivados por la observación no habría ciencia, y el único camino para lograr una percepción competente parece ser el hábito (Daston 2008: 98-100). 


\section{CAPITULO IV}

\section{EL ATLAS ANTROPOLÓGICO DE LA ESPERANZA}

En este capítulo se presentan y analizan las condiciones de posibilidad y circunstancias a través de las cuales Robert Lehmann-Nitsche pudo construir el "atlas antropológico" publicado en 1907 en los Anales del Museo de La Plata, con el título Estudios antropológicos sobre los Chiriguanos, Chorotes, Matacos y Tobas (Chaco Occidental). Ese trabajo de antropología física, donde la fotografía ocupaba un rol central fue realizado en 1906, en el ingenio azucarero La Esperanza (Jujuy), y allí se adjunta una serie de 50 láminas con fotografías de trabajadores indígenas. Comenzaremos por describir cuales fueron los antecedentes que llevaron a estos investigadores a realizar el viaje a Jujuy. Luego se hará una breve reseña histórica acerca de los inicios de la industria azucarera en Jujuy y su relación con los pueblos indígenas del Chaco occidental. Luego se describirá el contexto en que se tomaron las mediciones antropométricas y las fotografías, refiriéndonos al trabajo indígenas en los ingenios azucareros y discutiendo algunos trabajos que analizaron la relación de poder establecida entre los investigadores y los indígenas estudiados. Además se describirán los pormenores relacionados con la divulgación en medios de prensa locales y la publicación en los Anales del Museo de La Plata de los resultados obtenidos en ese viaje. Finalmente se establecen algunos paralelos entre la fotografía de Guido Boggiani y las imágenes producidas en La Esperanza para luego enfocarnos en los cambios observados en la concepción de la fotografía antropológica por parte de Lehmann-Nitsche y su "abandono" de las investigaciones en antropología física.

\section{Los antecedentes del viaje al Ingenio La Esperanza}

Luego de realizar el trabajo con los takshik, Lehmann-Nitsche continuó utilizando la fotografía como herramienta para sus investigaciones de campo, incorporando posteriormente este medio en la práctica docente. En 1902 realizó un viaje por Tierra del Fuego donde obtuvo una serie de imágenes fotográficas y realizó observaciones antropológicas que luego utilizó en diferentes publicaciones 
(Lehmann Nitsche 1916b y 1916c), adquiriendo además distintas fotografías reproducían vistas de paisajes, edificios, poblados y de indígenas fueguinos ${ }^{1}$. En 1903 podemos destacar entre sus actividades el dictado del primer curso universitario libre de antropología, que tuvo lugar en la Facultad de Filosofía y Letras de la Universidad de Buenos Aires, durante ocho reuniones. Allí, siguiendo un programa de antropología física, disertaría acerca de las características de pigmentación, del pelo, de la forma del cráneo y de la cabeza, de altura y de las proporciones de las distintas razas humanas, concluyendo con una clase en el Museo de La Plata sobre "el indígena argentino fósil y actual". (Podgorny 2001: 14)

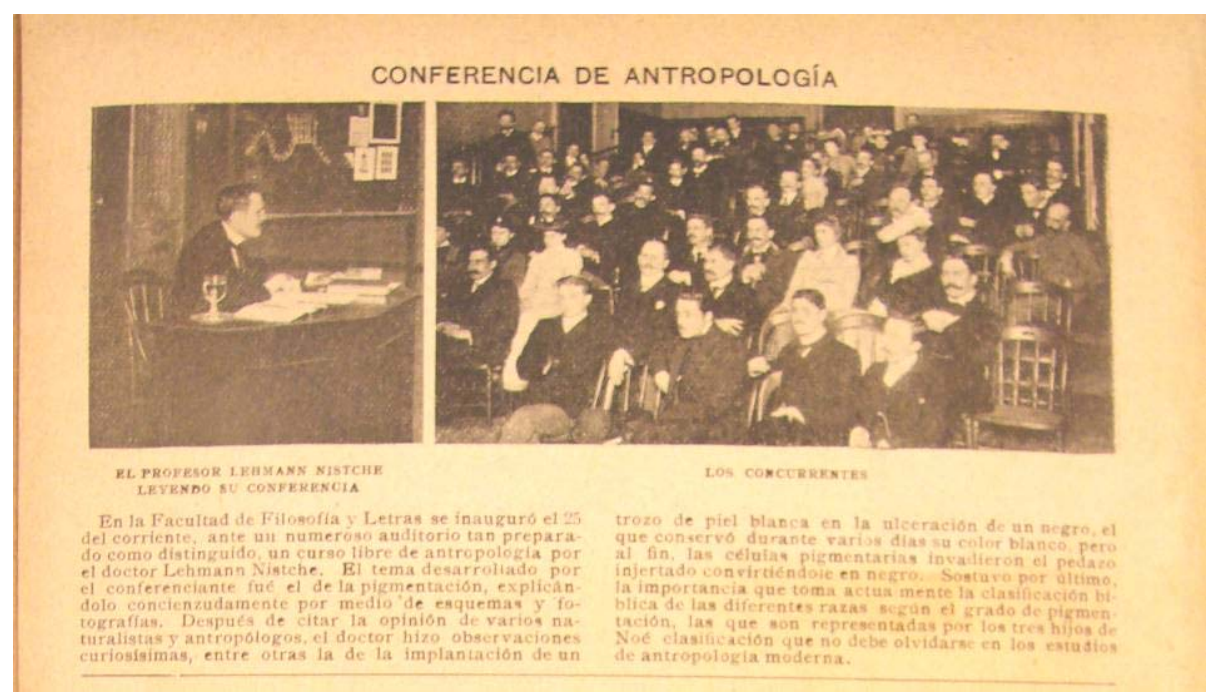

Figura 1. "Conferencia de Antropología", en los pies de foto puede leerse "El profesor Lehmann Nitsche leyendo su conferencia" y "Los concurrentes". Revista Caras y Caretas N² 262, 03/10/1903.

De acuerdo con una breve noticia acerca de este curso, publicada en la revista Caras y Caretas (Figura 1), la primera de esas conferencias se desarrolló el 25 de septiembre de 1903, y el tema tratado "fue el de la pigmentación, explicándolo concienzudamente por medio de esquemas y fotografías"2.

\footnotetext{
${ }^{1}$ En una de las carpetas con fotografías que forman parte del Legado de Robert Lehmann-Nitsche que se conserva en el Instituto Iberoamericano de Berlin se conservan, entre otras imágenes, 14 fotos de vistas y paisajes de Patagonia argentina que contienen inscripciones escritas a mano que no pertenecen a LehmannNitsche, y alrededor de 55 piezas, que retratan tanto a indígenas fueguinos como paisajes, edificios públicos, viviendas y poblados, entre los principales temas (Legado Robert Lehmann-Nitsche, IAI, Berlin, N-0070 s66). Otra de esas carpetas contienen también fotografías que al parecer fueron adquiridas durante ese viaje en Punta Arenas, Chile (Legado Robert Lehmann-Nitsche, IAI, Berlin, N-0070 s65)

${ }_{2}^{2}$ La nota finaliza señalando que Lehmann-Nitsche "Sostuvo por último la importancia que toma actualmente la clasificación bíblica de las diferentes razas según el grado de pigmentación, las que son representadas por los tres hijos de Noé, clasificación que no debe olvidarse en los estudios de antropología moderna." (Caras y Caretas N²62, 03/10/1903).
} 
Los antecedentes de este viaje se remontan, como ya vimos en el capítulo II, a fines de setiembre de 1903, cuando Carlos Bruch, acompañando a Francisco Moreno y a una comitiva de geólogos alemanes que habían llegado a Sudamérica para estudiar las formaciones geológicas de la región de la Puna (Hoek y Steinmann 1904), estuvo de paso por ese ingenio. Allí, Bruch se encontró con un panorama desconocido para él, la gran cantidad de trabajadores indígenas chaqueños que se hallaban en La Esperanza trabajando en la cosecha de la caña de azúcar. Tomó algunas fotografías con su cámara de mano (Figuras 2 y 3) e inmediatamente escribió a Lehmann-Nitsche comunicándole las posibilidades de realizar allí "un trabajo monumental"3.

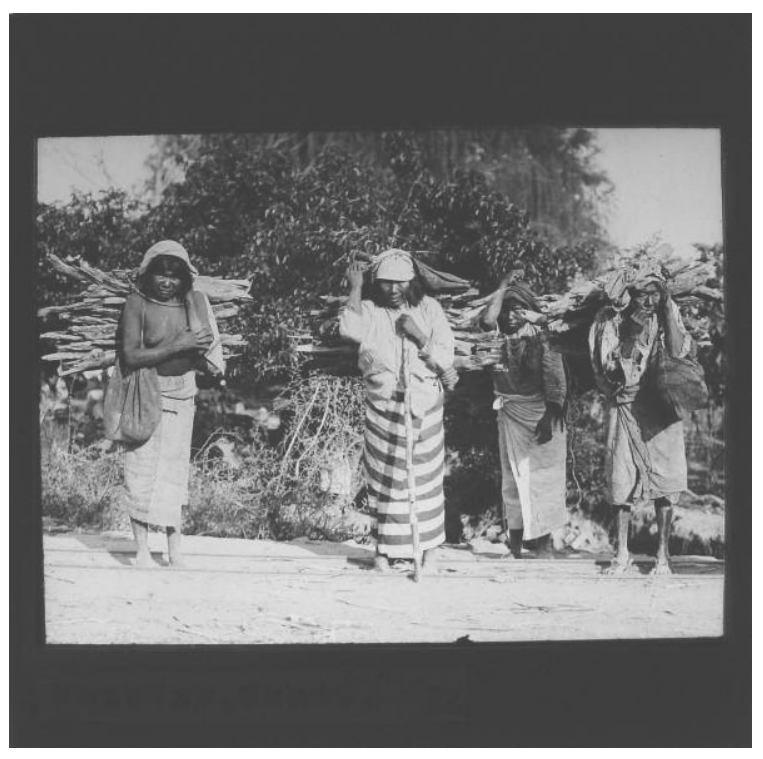

Figura 2. "Matacas. Chaco. Jujuy. 32" (C. Bruch, 1903, Ingenio La Esperanza) (Diapositiva de vidrio $8 \times 8 \mathrm{~cm}$.) (AFME)

Figura 3. "Indias Matacas. 34" (C. Bruch, 1903, Ingenio La Esperanza) (Diapositiva de vidrio 8X8 cm.) $(\mathrm{AFME})^{4}$

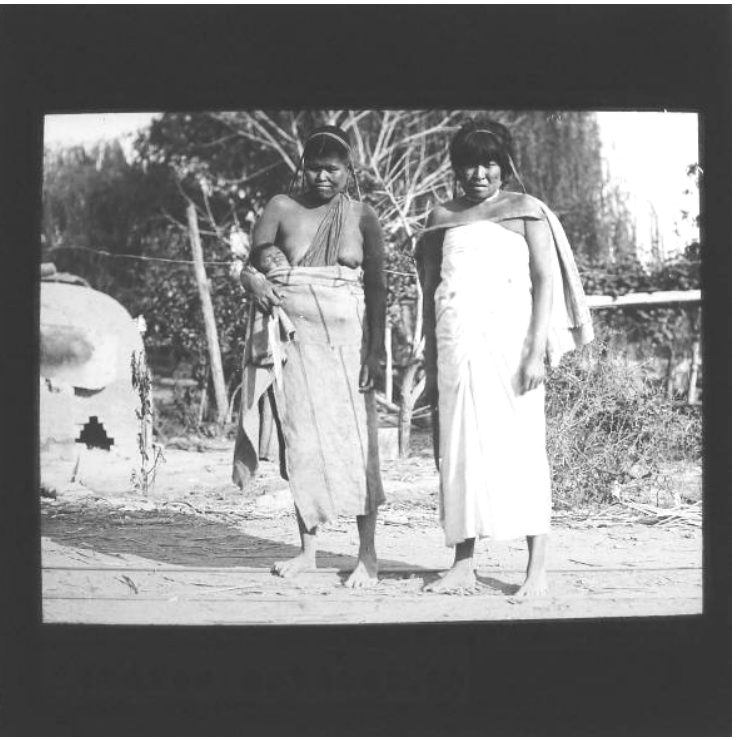

\footnotetext{
3 "Pasamos tres días en la selva totalmente atormentados por las garrapatas y los piques, por lo que nos fue imposible dormir durante tres noches. A la vuelta pasamos por San Pedro. Debido a que en el ingenio azucarero observé trabajar a muchos indígenas, fui hacia allí el domingo muy temprano. Logré tomar tipos de Chorrotos [SIC], Matacos y Chiriguanos, desafortunadamente sólo con la pequeña cámara de mano. Estaba completamente encantado y nunca pensé que uno puede encontrar aquí un material tan magnífico con tal facilidad. Si Usted entonces tuviera ganas en su próximo viaje de que emprendamos juntos esta excursión a Esperanza y Ledesma le puedo garantizar un trabajo monumental." Carta de Carlos Bruch a Robert LehmannNitsche, San Pedro, Jujuy 22 de setiembre de 1903. (IAI, Berlin, N-0070, b-60)

${ }^{4}$ En las figuras 2 y 3 , los rieles ferroviarios sobre los que están paradas las mujeres retratadas, son las vías de trocha angosta (dos pies) del ferrocarril tipo decauville que se utilizaba en el ingenio La Esperanza para transportar la caña cortada desde los distintos lotes de cultivo hasta la planta fabril (Sierra e Iglesias 1998: 43). Este ferrocarril interno contaba con una red fija de 30 kilómetros además de una red portátil de otros $15 \mathrm{~km}$. usada durante la época de cosecha, lo que nos da una idea aproximada de la extensión de este ingenio. Por otra parte, en la figura 2 vemos a la izquierda de la imagen un horno de barro, el mismo suponemos, que aparece en la Figura 15 del capítulo II.
} 
Finalmente, el viaje tuvo lugar tres años después, en el invierno de 1906. Justamente en ese año, el Museo de La Plata atravesaría por un significativo cambio institucional, al abandonar la órbita provincial, pasando a estar bajo la administración de la recientemente creada Universidad Nacional de La Plata ${ }^{5}$, como Instituto de Investigaciones y Facultad de Ciencias Naturales. Sería esta una nueva organización, donde algunos investigadores extranjeros a cargo de distintas secciones del museo ocuparían durante las dos siguientes décadas la doble función de jefes de sección y profesores titulares ${ }^{6}$ (García 2005: 35). Por otra parte, este traspaso dejó su marca en la historia de la antropología argentina. En la primera década del siglo XX, la universidad se presentaría como el lugar ideal para la producción de conocimiento y la formación de científicos locales, produciéndose un cambio substancial para esa disciplina, que desde mediados del siglo XIX había tenido en los museos y colecciones su principal lugar de institucionalización (Podgorny 2005: 66).

Este hecho marcó además el fin de la gestión de Francisco Moreno al frente del museo. Su lugar pasaría a estar ocupado por Samuel Lafone Quevedo, quien venía colaborando desde 1888 con esa institución en carácter de corresponsal ${ }^{7}$, aportando su colaboración no solamente desde el aspecto material y logístico sino también a través de sus relaciones personales, comerciales y académicas. En este sentido, fue por intermedio de las redes de sociabilidad en las que participaba el nuevo director que se hizo factible el viaje de 1906 al ingenio La Esperanza.

\footnotetext{
${ }^{5}$ En efecto la estructura académica de esta universidad se erigió sobre la base de una serie de establecimientos provinciales preexistentes y la creación de algunas secciones nuevas. Entre los primeros se encontraron además del Museo de la Plata, el Observatorio Astronómico, el Colegio Nacional, la Biblioteca Pública, la Facultad de Agronomía y Veterinaria y la Universidad provincial (Castiñeiras 1985, citado en García 2005). El proyecto para la nueva universidad fue elaborado en sus lineamientos generales por Joaquín V. González durante su gestión al frente del Ministerio de Instrucción Pública de la Nación, entre fines de 1904 y principios de 1906.

${ }^{6}$ Pese a que desde el inicio de esta nueva estructura se planteó y se puso en práctica la unión entre investigación y docencia, en el campo de la antropología se hizo manifiesto lo que Podgorny denomina "la incapacidad para formar una tradición heredable dentro de la disciplina", una situación que continuaría por muchos años más y que lleva a esta autora a cuestionar la idea de una universidad creada con el objetivo de consolidar la práctica científica en el país (Podgorny 2005: 89)

${ }^{7}$ Samuel Alexander Lafone Quevedo era un empresario minero dedicado a la filología y la arqueología. A partir de 1888, depositaría su colección arqueológica personal en el Museo de La Plata para formar la sub-sección de "Arqueología Calchaquí", y sería nombrado por Moreno como curador honorario de la misma. Como señala Farro (2009) Lafone Quevedo pondría a disposición de los empleados del museo la infraestructura de su explotación minera para el desarrollo de las tareas en el terreno, indicando los sitios apropiados para realizar excavaciones, actuando como corresponsal de la institución y coordinando las tareas de recolección de objetos en aquella región.
} 
Tal como lo marcaba Lehmann-Nitsche, refiriéndose a Lafone Quevedo:

"valiéndose pues, de las relaciones que mantiene con la colonia inglesa del país, y especialmente con los industriales azucareros del norte, pudo proporcionarse en la región del noroeste de la república, oportunidad de llevar a cabo con éxito una investigación antropológica" (Lehmann-Nitsche, 1907a: 53)

En efecto, Lafone se había comunicado por correspondencia con Walter Leach, uno de los propietarios del ingenio La Esperanza, el 12 de junio de 1906, consultándolo acerca de la posibilidad de que Robert Lehmann-Nitsche y Carlos Bruch se trasladasen hasta allí para realizar un estudio antropológico sobre los indígenas chaqueños que se hallaban trabajando en la zafra. El 21 de ese mismo mes, Walter Leach responde diciendo que los recibiría "en cualquier momento que ellos gusten pasar". . Un mes después, ambos iniciaban el viaje trasladándose en tren hasta la ciudad de Córdoba. Allí estuvieron con el Dr. Adolfo Doering (1848-1925) ${ }^{9}$, naturalista y geólogo alemán, llegó al país a propuesta de Burmeister para integrar la Academia Nacional de Ciencias de Córdoba. Fue decano de la Facultad de Ciencias Exactas, Físicas y Naturales de la Universidad de Córdoba.con quien Lehmann-Nitsche estudió la formación pampeana de esa provincia, un tema que Doering venía tratando desde tiempo atrás (Cfr. Podgorny y Lopes 2008). Este último le dictó a Lehmann-Nitsche un manuscrito sobre esa formación, que sería incluido en su trabajo sobre el hombre fósil ${ }^{10}$ (Lehmann-Nitsche 1907c) ${ }^{11}$. Además, Doering había sido el fundador de la Sociedad Entomológica argentina junto con el holandés Hendrik Weyenbergh. Mientras tanto, Carlos Bruch aprovecharía su estadía en Córdoba para estudiar la colección entomológica del Sr. Federico Schulz ${ }^{12}$, preparador-conservador y segundo de Doering en el Museo de Zoología

\footnotetext{
8 "We shall be very pleased to see Dr. Robert Lehmann-Nitsche y Mr. Charles Bruch any time that they may care to come up." (Carta de Walter Leach a Samuel Lafone Quevedo, 21 de junio de 1906)

9 Zoólogo, químico y geólogo de origen alemán que se desempeñaba como secretario de la Academia de Ciencias y era además docente de la Universidad de Córdoba.

${ }_{10}$ Carta de Carlos Bruch y Robert Lehmann-Nitsche a Samuel Lafone Quevedo del 28 de julio de 1906 (AHFMLP)

${ }^{11}$ En este sentido cabe recordar que los antropólogos de la Universidad de La Plata estaría centrada en discutir los problemas sobre la evolución del género humano planteados por Ameghino (Podgorny 2005: 82). En ese plan, Lehmann-Nitsche publicaría, al año siguiente de su visita a Doering, un extenso trabajo que daba cuenta del estado de la cuestión sobre el hombre fósil de la formación pampeana, discutiendo los hallazgos de Ameghino y Roth (Lehmann-Nitsche 1907c) (Cfr. Podgorny 2001)

12 Decía Bruch acerca de esta colección: "Existe en la colección una cantidad numerosa de especies interesantísimas y probablemente entre ellas muchas nuevas, las cuales nos han sido ya aseguradas para su
} 
de esa universidad (Ringuelet 1967: 15; Acosta 2006: 5). Partirían luego de Córdoba para Tucumán, donde Bruch estudió las colecciones ornitológicas y entomológicas de la colección de Miguel Lillo. Luego de esto, siempre en ferrocarril, llegaron a San Salvador de Jujuy el 28 de julio de $1906^{13}$, permaneciendo allí alrededor de tres días y aprovechando la ocasión para hacer colecciones de objetos textiles ${ }^{14}$. El 1 de agosto de 1906 comenzaban su trabajo en el ingenio La Esperanza ${ }^{15}$.

\section{Los indígenas del Gran Chaco y el trabajo en la zafra}

Las primeras plantaciones de caña dulce y la elaboración artesanal de azúcar en el valle del río San Francisco datan de fines del siglo XVIII, y se produjeron en las fincas propiedad de Gregorio de Zegada, gobernador militar de Jujuy, una vez que los españoles quebraron la resistencia indígena y tomaron posesión de ese valle (Tello 1888: 137). Estas y otras pequeñas extensiones cultivadas con caña de azúcar fueron las que dieron origen, en la mayoría de los casos, a los grandes ingenios azucareros que se fundaron a fines del siglo XIX en las provincias de Salta y Jujuy (Zuleta 1990: 44). Desde un primer momento estas fincas saltojujeñas utilizaron mano de obra indígena proveniente del Chaco occidental, quienes ya trabajaban en las haciendas y ciudades de la frontera de esa frontera al menos desde mediados del siglo XVIII, y tal como señala Daniel Santamaría el trabajo de los indígenas chaqueños en los cañaverales del valle del San Francisco, como forma de "castigo" o voluntariamente en respuesta a las solicitudes españolas, se remonta al menos hasta los comienzos del siglo XIX (Santamaría 1996: 283-289). Cabe recordar que durante el período colonial los planes españoles de ocupación del territorio chaqueño combinaban las llamadas "entradas" civilizadoras, con la acción evangelizadora de jesuitas, primero, y franciscanos, después. La idea central de estos emprendimientos, era una educación cultural integral del indígena para "integrarlo" al estatus de "cristiano", o sea, de un ser civilizado y redimible; una conversión total para transformarlo en un ser útil a la sociedad. Y básicamente este concepto de utilidad giraba en torno a la capacidad de trabajo que podían generar

estudio. Se ha podido tomar además muchos datos importantes y catalogar especies ya conocidas de otras regiones pero ignoradas hasta hoy de la fauna argentina." ("Informe de la Sección Zoología 1906", AHFMLP)

${ }_{13}$ Carta de Walter Leach a Samuel Lafone Quevedo, 21 de junio de 1906.

14 "Informe de la sección antropo- y etnológica desde el $1^{\circ}$ de Febrero hasta el 31 de diciembre de 1906" (AHFMLP)

${ }^{15}$ Ibid. ant. 
estas poblaciones (Wright 2003: 138). Teruel (1999) y Tamagno (2001) marcan la importancia que la sujeción de la mano de obra en quebrachales e ingenios tuvo para el diseño de las nuevas condiciones de existencia que se impondrían con la expansión colonial y con la gestación y consolidación del estado nación.

Hacia la primera mitad del siglo XIX un viajero norteamericano que se encontraba de paso por Jujuy relataba que en su ruta al pueblo de Orán, desde la ciudad de Salta, atravesó por densos bosques que se interrumpían ocasionalmente por campos abiertos, casi todos los cuales estaban dedicados al cultivo de caña de azúcar, y en Ledesma y San Pedro observó extensas fábricas de azúcar (King 1846: 69). En efecto, de acuerdo con Schleh, para 1830 ya se había establecido en Ledesma una fábrica de azúcar (Schleh 1945: 265). Pasada la primera mitad de ese siglo, si bien algunas de esas fábricas habían reemplazado los trapiches de madera por otros de hierro, estos seguían siendo impulsados por tracción animal. Además, las técnicas utilizadas para la extracción del jugo de la caña eran obsoletas, afectando la calidad del azúcar producido. Por otro lado esta industria también estaba limitada en términos comerciales con una mano de obra incierta y circunscripta a un mercado lugareño, lo que hizo que su expansión resultase difícil al menos hasta el último tercio del siglo XIX (Rutledge 1987:13; Santamaría 1986: 9)

En 1876 Ilegaba a la Argentina Roger Leach (1853-1889), un ingeniero inglés que vino a supervisar la instalación en el ingenio Ledesma de las modernas máquinas a vapor $^{16}$ adquiridas por sus propietarios, los hermanos Ovejero Zerda. Luego de esto Leach se radicó en la ciudad de Salta, dedicándose a la venta de maquinarias y al asesoramiento técnico para los ingenios azucareros. En 1882 se asoció con Miguel Aráoz, un acaudalado político e industrial azucarero salteño, para establecer en su Finca San Pedro, en el valle del río San Francisco, un nuevo ingenio que se llamaría La Esperanza y que comenzó a funcionar en $1884^{17}$. A los pocos años, en 1892 un

\footnotetext{
${ }^{16}$ Para ese año el ferrocarril llegaba sólo hasta Tucumán por lo que las nuevas maquinarias fueron trasladas en carretas desde allí hasta Ledesma (Routledge 1987: 13)

${ }^{17}$ Luego de diversos traspasos y movimientos accionarios, este ingenio pasaría a ser propiedad exclusiva de la familia Leach en 1899. En efecto, luego de que Roger Leach iniciara esta empresa fueron llegando, entre 1881 y 1893, provenientes desde Inglaterra, Australia y Nueva Zelanda, sus cinco hermanos: Walter, Stephen, Norman, William, Frank y Emmeline. Tanto Roger como Walter y Stephen habían trabajado además en el ingenio Ledesma. El ingenio La Esperanza era una explotación agrícola, pero no era la única explotación administrada por los Leach, quienes manejaban una empresa económica diversificada. Walter Leach era el administrador del ingenio. Stephen Leach fue el director técnico luego del fallecimiento de Roger en 1889. William Leach también realizaba tareas administrativas en La Esperanza. En la gran extensión de tierras que poseían en el valle de San
} 
tercer ingenio, además de Ledesma y La Esperanza, sería fundado en el este de Jujuy, Ilamado La Mendieta, era propiedad de la firma Alvarado y Muller (Routledge 1987: 17).

A partir de 1900 la industria azucarera pasó a ser la actividad económica más importante de Jujuy. En esa provincia, y también en Salta, la unidad de producción estaba conformada por el complejo fábrica-plantación (Rutledge 1987: 19). En efecto, casi la totalidad del valle del río San Francisco era propiedad de los ingenios Ledesma, La Esperanza y Mendieta, a diferencia de lo que ocurría en Tucumán donde esos establecimientos actuaban mayormente como acopiadores y refinadores que compraban la caña cultivada por pequeños y medianos productores independientes (Conti y otros 1988:3). A esos tres ingenios concurrían anualmente, según nos relata un cronista de la época "más de 10.000 indios procedentes del oriente y sud de Bolivia y del Chaco y Formosa, los que junto con los indios del norte de la provincia y con los elementos criollos, desempeñan toda la labor de la cosecha" (Schleh 1921: 267) y tan solo para el ingenio de La Esperanza acudían anualmente "en número de más de 3.000."18 (Schleh 1910: 129). En este sentido, ya desde sus inicios estos ingenios recurrieron a los indígenas del Chaco como mano de obra para la zafra, dado que los trabajadores de las provincias de Tucumán, Santiago del Estero y Catamarca se hallaban ocupados en los ingenios tucumanos (Sierra e Iglesias 1998: 36). La búsqueda de brazos para la zafra se transformó en un punto clave del nuevo sistema productivo azucarero ya que, a diferencia de lo que ocurrió con las antiguas factorías de corte artesanal, estas grandes usinas requirieron una enorme cantidad de mano de obra para funcionar.

Como explica Gastón Gordillo (2004), la campaña de Victorica en 1884, y la expansión de las inversiones capitalistas produjeron en el Chaco nuevas geografías

\footnotetext{
Francisco y otros lugares de la región, cada uno de los hermanos se ocupaba de dirigir distintas actividades. Frank Leach estaba encargado de las explotaciones mineras de Mina de Asfalto y El Quemado, una calera y una mina de mármol ónix en Las Cañadas, además de las inversiones que la sociedad tenía en "Mina Pirquitas" en el noroeste de Jujuy. Norman Leach estuvo a cargo de lo que se denominó sección finca, donde se realizaban explotaciones ganaderas y madereras (Sierra e Iglesias 1998: 7-24). Decía Bialet Massé sobre este ingenio en 1904: "Todo el pueblo excepto 2 casas es propiedad de los Leach (...) Allí no puede vivir nadie si no les arriendan, ni establecer casa de comercio que no les sea tributaria en una u otra forma; generalmente son asociados o habilitados hasta en las carnicerías (...) No solo el pueblo es propiedad de los señores Leach; la finca tiene treinta y cinco leguas cuadradas, que constituyen un verdadero emporio." (Bialet Massé 1973: 56)

${ }^{18}$ Bialet Massé informa que para 1904 los indígenas que trabajaban allí sumaban dos mil quinientos hombres, en tanto que para la zafra de 1910 el ingenio habría ocupado aproximadamente a cinco mil trabajadores indígenas (Zuleta, 1990).
} 
que no cobraron el mismo carácter en toda la región. Por un lado, hacia el sur y el este se produjo una masiva reconfiguración geográfica y social, a través del loteo de tierras expropiadas a los grupos indígenas y puestas en manos de inversores y especuladores. En ese contexto, algunos grupos toba y mocoví pasaron a formar parte de un proletariado sin tierra asentado en las afueras de los pueblos, mientras que otros a su vez fueron arrinconados en tierras todavía fiscales donde continuaron sobreviviendo de la marisca ${ }^{19}$, ante el avance del alambrado colocado por grandes empresas madereras primero y algodoneras más tarde. Por otro lado, y siempre según este autor, hacia el oeste y las regiones aledañas al río Pilcomayo, las nuevas geografías tuvieron una expresión diferente. A principios del siglo $X X$ la presencia estatal allí era todavía débil, y los inversionistas estaban menos atraídos por esas tierras, muchas de las cuales continuaban aún en manos del gobierno nacional. La expansión del capitalismo en esa región reconfiguró el espacio no por intermedio de la expropiación de tierras sino a través de su transformación en una en una gran fuente de fuerza laboral para las plantaciones del valle del río San Francisco (Gordillo 2004: 49-51).

En efecto, desde la década de 1890, y antes de su gran expansión productiva, los ingenios comenzaron a enviar intermediarios al interior del Chaco en busca de cosecheros estacionales, sobre todo entre los indígenas de la región CentroOccidental, pero también (aunque en menor medida) entre grupos ubicados más al este, como los pilagás y algunas parcialidades tobas del Chaco Oriental, llegando a emplear incluso indígenas de los actuales territorios de Bolivia y Paraguay. En estas incursiones, los "mayordomos" enviados por los ingenios, que a veces contaban con el apoyo del ejército de frontera, llevaban consigo gran cantidad de mercaderías, caballos y armas de fuego, que ofrecían a los caciques como anticipo si se desplazaban a la zafra (Bialet Massé 1985; Iñigo Carrera 1984; Gordillo 1995). A medida que las agroindustrias del azúcar se expandían, se tornaba más imperiosa la necesidad de garantizar la "extracción de indios" de la frontera, convirtiéndose en la problemática tal vez más acuciante para la expansión del capital agrario de la región. Para Trinchero, sin embargo, no serán las campañas militares las que

${ }^{19}$ Término que refiere en sentido amplio a actividades de caza, pesca y/o recolección de alimentos. 
garantizarán el reclutamiento necesario, sino la misma patronal de los ingenios ${ }^{20}$. La captación de esta mano de obra para trabajar en la zafra comenzaba a mediados de marzo coincidiendo con el inicio de la estación seca, momento de menores rindes de las actividades de caza, pesca y recolección. Como marca ese autor, esta situación constituiría un elemento de importancia en el éxito de la patronal en lograr el reclutamiento de fuerza de trabajo, ya que al llegar los "contratistas" a las poblaciones indígenas, la escasez de alimentos para la subsistencia tendía a propiciar el "enganche" (Trinchero 2000:161-165).

\section{Las respuestas indígenas. Fotografía, poder y resistencia.}

No es el objetivo de este capítulo ni de esta tesis ofrecer una discusión en profundidad acerca de la relación entre fotografía y poder, cuestión para la cual referimos, entre otros, a los reconocidos trabajos de Alan Sekula (1986) y John Tagg (1988). Sin embargo estas cuestiones merecen una reflexión ya que ellas se hacen aparentes cuando nos concentramos en las condiciones de producción de las imágenes. En este sentido, y a partir de las evidencias visuales y escritas que aquí se consideran podemos aportar nuevos datos acerca de la relación que se estableció entre los investigadores y los indígenas en el contexto del ingenio, rastros que pueden, por una parte, ayudarnos a comprender la particular dinámica que alcanzaron las relaciones de poder entre ambos sujetos; y que, por otro lado, nos permiten reconocer lo mucho que ha pasado inadvertido sobre la vida política activa de estos grupos subordinados que se realiza en un nivel que raras veces se reconoce como político (Scott 2000:233; Tamagno 2001)

De acuerdo a lo señalado anteriormente sabemos que uno de los propósitos de este viaje fue aprovechar la presencia de esos grandes contingentes de indígenas chaqueños que año tras año eran llevados a La Esperanza, y a los demás ingenios de Salta y Jujuy a fin de emplearlos como braceros en la zafra, para efectuar sobre ellos un estudio somatológico. A diferencia de lo ocurrido entre los takshik en 1899

\footnotetext{
${ }^{20}$ En este punto se aleja de la perspectiva de Campi y Lagos, por ejemplo, para quienes: "El rol del ejército en este proceso fue clave. Encargado de preservar el orden y la tranquilidad públicas en una zona de frontera, participó -en los años iniciales del "despegue"- en las tareas de reclutamiento, traslado y custodia de los contingentes chaqueños. En la segunda década del siglo XX, esa participación adquirió otro carácter. Los comandantes militares se desempeñaron como "árbitros" de una relación que nunca dejó de ser conflictiva, la de las empresas con las distintas parcialidades." (Campi y Lagos 1994: 197)
} 
aquí Lehmann-Nitsche contaría con varios problemas resueltos; en primer lugar podría examinar tanto a mujeres y niños como a varones jóvenes y adultos, pudiendo incluso en algunos casos retratarlos desnudos. En ese sentido, él mismo señalaba que "Los individuos, ya fuera de su acostumbrado ambiente, son por lo mismo, más accesibles á investigaciones físicas, y no se oponen a ellas como sucede en el propio terruño." (Lehmann-Nitsche 1907: 54). Sin embargo, como veremos aquí esto no era válido para todos los casos.

Conseguir que las personas se desnudaran y accedieran a ser medidos y fotografiados, era una tarea que generaba bastante dificultad. Es frecuente encontrar en las publicaciones científicas de aquellos años referencias a los problemas en lograr este tipo de fotografías. Debido a estos obstáculos, los antropólogos buscaron algunas vías alternativas para obtener las imágenes que deseaban. Zimmerman (2003), refiriéndose específicamente a la antropología alemana de fines del siglo XIX, señala que los datos empíricos para las investigaciones pudieron obtenerse gracias a una economía política que hizo accesible los cuerpos de los pueblos no europeos al conocimiento antropológico, mostrando así la interdependencia entre la antropología física y el régimen colonial. Algo similar ocurría en el ámbito de la antropología francesa donde, como señala Dias, los sujetos fotografiados estuvieron bajo control ya sea en el espacio colonial o en la metrópoli, en ocasión de las exhibiciones realizadas en las Exposiciones Universales y en el Jardín de Aclimatación (Dias 1994b: 42).

En el mismo sentido que estos dos autores se expresaba, más recientemente, Gastón Gordillo, al remarcar que los trabajos realizados por Lehmann-Nitsche entre los pueblos indígenas del Chaco habían tenido lugar en lo que ese autor denomina "lugares de disciplinamiento" (Gordillo 2005). Recordemos además las dificultades enfrentadas por ese antropólogo cuando hacía notar "las extrañas circunstancias del medio en el cual estuve forzado a trabajar" (Lehmann-Nitsche 1904a:264), refiriéndose a la limitación que le pusieron las monjas del Asilo Correccional de Mujeres para tomar fotografías y mediciones de los cuerpos desnudos de las mujeres takshik. Además de estas reservas, y como ya se señaló en el capítulo anterior, existieron otras presentadas por las mismas takshik, reservas que sólo pudieron ser superadas a través de la mediación ejercida por el intérprete y otras 
dos mujeres que conformaban el grupo. Y aún en ese caso Lehmann-Nitsche no logró medir a todas ellas.

Algunas situaciones en cierto modo análogas a ésta última tendrían lugar en La Esperanza. Allí, Lehmann-Nitsche contaría con un apoyo clave para llevar adelante las observaciones, mediciones y fotografías de los cuerpos de los indígenas. La relación con los hermanos Leach les valió a los investigadores mucho más que el acceso al ingenio:

"Mr. Walter Leach, (...) por su carácter amable y franco y por esa bondad de corazón noble, desde años atrás se había ganado la confianza absoluta de los indígenas así que no se resistían a obedecer su indicación de permitirnos un examen somático de sus personas (...) nos hospedó en su casa particular y puso á nuestra disposición un lugar adecuado para nuestros estudios, y al frente mismo de nuestra pieza, interesándose vivamente en nuestros trabajos, al conocer su índole; no se cansaba de mandarnos gente día a día y cada mañana, llevándonosla hasta personalmente, para ser examinada". (Lehmann-Nitsche, 1907a: 55).

La colaboración de los Leach no fue capitalizada solamente por Lehmann-NItsche sino que otras investigaciones antropológicas llevadas a cabo en su ingenio contaron también con su asistencia y apoyo. Este es el caso del arqueólogo sueco Eric Boman (1908), quien como parte de la misión científica francesa pasó por ese ingenio en $1903^{21}$, contó con el favor de sus dueños, del mismo modo que lo hiciera el barón Erland Nordenskiold, arqueólogo y etnógrafo, también sueco, que estuvo allí 1901 y 1908. En esta última oportunidad, al igual que Bruch y Lehmann-Nitsche estuvo alojado en la casa principal de los Leach $^{22}$, permaneciendo durante un mes en ese ingenio, donde pudo reencontrarse con algunos de sus "amigos indios" que

\footnotetext{
21 "En el momento de mis viajes en la provincia de Jujuy, los señores Leach me colmaron de toda clase de atenciones, y aprovecho esta ocasión para expresarles mi viva gratitud." (Boman 1908: 834)

22 "Fui recibido con la mejor buena voluntad por los hermanos Leach, los propietarios del ingenio Esperanza (...) Era un sentimiento extraño sentarse sobre un trozo de madera en la choza de hierba con un fuego pobre y oír la narración sobre como los cerdos salvajes robaron al armadillo el maíz y como el cobayo robó del Jaguar el fuego y lo dio a los Matacos, y sentarse algunos momentos más tarde en una silla cómoda en el confortable hogar inglés de los Leach y hablar sobre política, naves voladoras y deportes. Los contrastes en la vida siempre causan placer." (Nordesnkiold 1912: 4-5, mi traducción)
} 
había conocido en el primer viaje $\mathrm{e}^{23}$, aprovechando además su estadía para realzar algunos estudios sobre ellos (Nordelskiold1912: 4).

Figura 4. "Matacomädchen, Esperanca." [Muchacha mataco, Esperanza] (Nordenskiold 1912)

A pesar de la buena disposición mostrada por Walter Leach y de que en La Esperanza los indígenas estaban "lejos de su terruño", los trabajos antropométricos no se realizaron sin inconvenientes, aunque es posible pensar que, dada la gran cantidad de indígenas que se hallaban en ese momento en el ingenio, estas dificultades hayan tenido un impacto

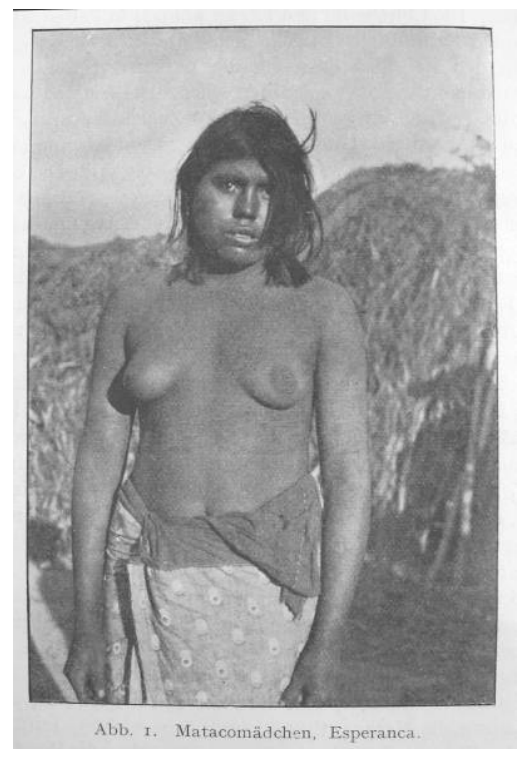
menor sobre los resultados de la investigación. En una carta escrita el 6 de agosto de 1906, desde La Esperanza, Lehmann-Nitsche comunicaba los avances en el trabajo a la vez que marcaba algunas dificultades encontradas:

"Hasta la fecha continuamos con el mayor empeño el estudio de los Chorotes, después que hemos medido y rotulado 35 Chiriguanos. El trato con esta tribu presenta más dificultades y demora el trabajo. No todos los individuos se prestan con buena voluntad. Sin embargo esperamos de completar un buen número hasta fin de esta semana. Como todas las otras tribus (Matacos y Tobas) están desparramados por los cañaverales, nos aconsejó Mr. Leach que hiciéramos unas visitas a San Antonio ${ }^{24} .25$

De este modo podemos entender que los estudios sobre la población indígena del ingenio La Esperanza no hubieran sido posibles sin la existencia de una asimetría

\footnotetext{
${ }^{23}$ Von Rosen (1904: 10)

${ }^{24}$ El ingenio La Esperanza, debido a la gran extensión de sus plantaciones que para esa época alcanzaban las 3000 hectáreas -alrededor de 30 kilómetros cuadrados- estaba dividido en una serie de lotes cada uno de los cuales era administrado por un inglés o un súbdito de la corona inglesa y que contaba con oficinas y se encontraba comunicado con el resto de los lotes y la fábrica de azúcar por medio del ferrocarril decauville. Para la primera década del siglo XX estos lotes eran San Antonio, Parapetí, Providencia, etc. Por otro lado la patronal buscaba no mezclar las parcialidades indígenas, especialmente tobas con matacos aduciendo que entre ellos se

${ }_{25}$ Carta de Robert Lehamnn-Nitsche y Carlos Bruch a Samuel Lafone Quevedo, La Esperanza, 6 de agosto de 1906 (AHFMLP).
} 
de poder entre las parte que integraron ese proceso de comunicación, un conjunto de relaciones de dominación, que se hallaban implícitamente naturalizadas y cuyas consecuencias son radicalmente distintas para colonizadores y colonizados (Pacheco de Oliveira 2006: 206). Algunos análisis de las imágenes fotográficas, entienden que es posible hallar, en ese medio, las huellas de un encuentro desigual que habría quedado inscripto en poses, gestos y miradas de temor, rechazo y resistencia. En nuestro caso, luego de reflexionar con detenimiento sobre estos temas $^{26}$ y a pesar de que contamos con un material visual que bien podría ser interpretado de la forma planteada, resulta complejo argumentar acerca de la docilidad/resistencia manifestada por los indígenas retratados contando con las fotografías como única fuente. Para realizar afirmaciones en esos términos, desde la actualidad, consideramos necesario recurrir y apoyarnos además en otras fuentes, que contribuyan a enriquecer el análisis y nos prevengan de la formulación de juicios o hipótesis que podrían resultar azarosas. En ese sentido entendemos que estas cuestiones nos indican por un lado los límites de las fotografías históricas para dar cuenta de determinados cuestiones y, por otro parte, vuelve imprescindible contar con documentos de otra índole, como los que aquí expusimos, y que den cuenta por ejemplo, de las dificultades que los investigadores tuvieron al tratar de medir y fotografiar a los indígenas.

Ya que el procedimiento fotográfico, para inicios del siglo XX, había alcanzado un desarrollo tecnológico que permitía entre otras cosas fijar una imagen en un cuarto de segundo, podrá notarse que toda argumentación acerca de la relación establecida entre fotógrafo y fotografiado, a partir de la interpretación que realiza el investigador sobre el gesto adoptado por las personas en el efímero instante en que fueron retratadas, podría ser discutible. En este sentido entendemos que sería igual de aventurado, pensar que si las personas fotografiadas muestran un gesto que podría entenderse como de distención o incluso una sonrisa, estaríamos en presencia de un indicio de la relación simétrica o igualitaria entablada entre ambas partes. Como marca Pacheco de Oliveira, "La relación colonial Ilega al nativo antes

\footnotetext{
${ }^{26}$ Vale recordar que en otro lado hemos participado de esta clase de interpretaciones que ahora cuestionamos (Martínez y otro 2006). Sin embargo, no entendemos este giro como una contradicción, sino más bien como parte de un proceso de aprendizaje -en el sentido de cambio- en el análisis histórico de las imágenes visuales, un campo en el cual, a pesar de lo mucho que se ha trabajado recientemente, creemos que puede resultar fortalecido por los aportes realizados desde otras perspectivas y disciplinas.
} 
y de forma independiente de la investigación, muchas veces sin que el etnógrafo se aperciba de ella, estando presente, por supuesto, después que el trabajo de campo se termina o incluso después de cesar sus efectos cognitivos" (Pacheco de Oliveira 2006:207)

\section{Los "obreros de la ciencia" y la divulgación de sus investigaciones}

Un mes después de concluida la investigación en La Esperanza, la revista Caras y Caretas publicaba una nota de una página donde se mencionaban los trabajos realizados por Lehmann-Nitsche y Bruch, incluyéndose además algunas de las fotografías tomadas en esa ocasión ${ }^{27}$ (Figura 5). Esa breve nota finalizaba reproduciendo el extendido lema que por esos años daba como inminente la desaparición de los pueblos indígenas chaqueños, los cuales, se señalaba, pasarían "como una sombra ignorada, si los obreros de la ciencia, abandonando su gabinete, no nos trajeran de allá datos preciosos"28. Lejos de entender esa publicación, y especialmente esta última frase, como un hecho aislado o anecdótico corresponde relacionarlo con el papel de la prensa en la publicidad y modelado de las actividades institucionales y el uso de los fondos públicos. Tal como señala Susana García, a fines de 1906 el museo comenzaría a enviar noticias acerca de las expediciones arqueológicas realizadas por su personal, luego de que un medio de prensa local ${ }^{29}$ denunciara la existencia de cargos docentes que se cobraban sin registrar actividad efectiva (García 2010: 151). Por otro lado debemos tener en cuenta que el vínculo con la revista Caras y Caretas venía de tiempo atrás, cuando, como vimos en los capítulos II y III, distintas imágenes fotográficas y noticias relacionadas con el museo habían sido publicadas allí. En este sentido recordemos que en 1902 Carlos Correa Luna, para entonces director de esa revista, se dirigía mediante una carta a Lehmann-Nitsche recordándole que

\footnotetext{
${ }^{27}$ Tres de las cinco imágenes que conforman la nota de Caras y Caretas no fueron publicadas en los Anales del Museo de La Plata de 1907; la imagen grupal debajo del título, la del muchacho en exterior en el centro de la página y, a la derecha de esta última, el retrato de la chica tatuada (Ver Figura X) Allí se afirma que como resultado de este viaje se habían producido 300 placas fotográficas, un número, que no figura, ni en el trabajo que publicaran en los Anales del Museo, ni en las Memorias de esa institución del año siguiente.

${ }^{28}$ Revista Caras y Caretas $N^{\circ} 416,22 / 09 / 1906$.

${ }^{29}$ Diario El Día, de La Plata.
} 
"Hace algún tiempo tuve el gusto de conversar con Ud. en la calle, á los pocos días de su regreso de la Tierra del Fuego, y, si mal no recuerdo me prometió Ud. un artículo y fotografías de su excursión, para "Caras y Caretas". Será mucha impertinencia recordarle su gentil promesa agregándole ahora que la dirección del periódico me encarga insistir sobre este asunto?" 30

De esta forma, y al menos para el caso de esta publicación, puede argumentarse que ello fue producto de un interés mutuo de las partes. Mientras la divulgación de los resultados de las investigaciones del museo en las revistas no académicas podía responder a las necesidades de esa institución, en el sentido de dar cuenta al gran público de los progresos realizados, y a fin justificar y mantener el financiamiento recibido por parte del Estado, también ponía de manifiesto los imperativos editoriales propios de aquellos medios. (Cfr. Podgorny 1999)

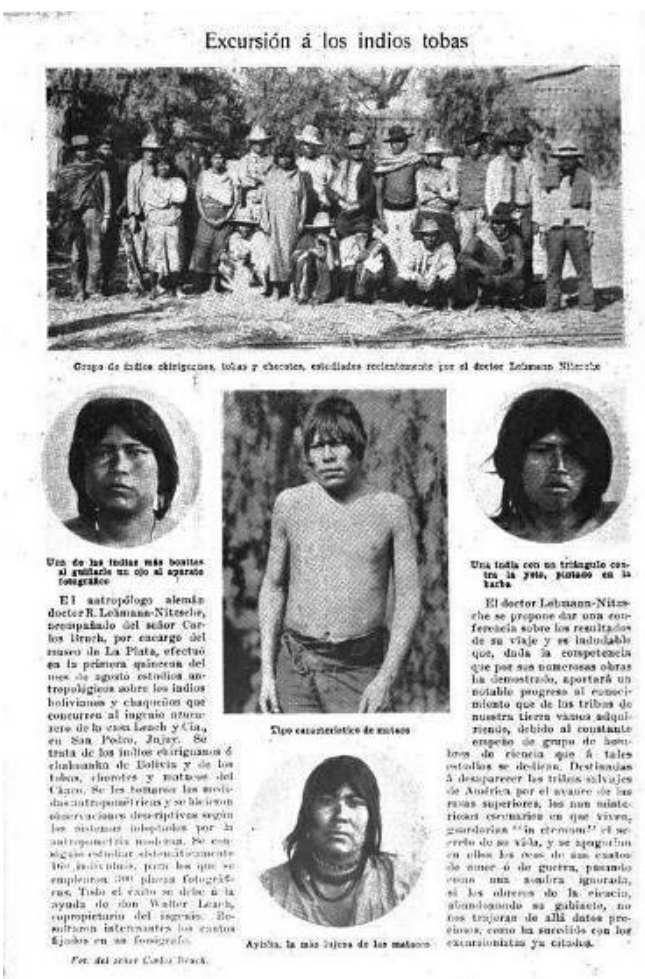

Figura 5. "Excursión á los indios tobas" Revista Caras y Caretas $N^{\circ} 416,22 / 09 / 1906$.

"El antropólogo alemán doctor R. Lehmann-Nitzche [SIC], acompañado del señor Carlos Bruch, por encargo del museo de La Plata, efectuó en la primera quincena del mes de agosto estudios antropológicos sobre los indios bolivianos y chaqueños que concurren al ingenio azucarero de la casa Leach y Cía., en San Pedro, Jujuy. Se trata de los indios chiriguanos ó chahuanka de Bolivia y de los tobas, chorotes y matacos del Chaco. Se les tomaron las medidas antropométricas y se hicieron observaciones descriptivas según los sistemas adoptados por la antropometría moderna. Se consiguió estudiar sistemáticamente 160 individuos, para los que se emplearon 300 placas fotográficas. Todo el éxito se debe á la ayuda de don Walter Leach, copropietario del ingenio. Resultaron interesantes los cantos fijados en un fonógrafo.

El Dr. Lehmann-Nitzche se propone dar una conferencia sobre los resultados de su viaje y es indudable que, dada la competencia que por sus numerosas obras ha demostrado, aportará un notable progreso al conocimiento que de las tribus de nuestra tierra vamos adquiriendo, debido al constante empeño de grupo de hombres de ciencia que á tales estudios se dedican. Destinadas á desaparecer las tribus salvajes de América por el avance de las razas superiores, los aun misteriosos escenarios en que viven, guardarían "in eternum" el secreto de su vida, y se apagarían en ellos los ecos de sus cantos de amor ó de guerra, pasando como una sombra ignorada, si los obreros de la ciencia, abandonando su gabinete, no nos trajeran de allá datos preciosos, como ha sucedido con los excursionistas ya citados."

\footnotetext{
${ }^{30}$ Continuaba diciendo Correa Luna: "Sería un verdadero placer para mí, y, -estoy seguro- para los lectores de "Caras y Caretas", leer un apercu de su viaje, con los interesantes datos que ha recojido y las buenas reproducciones fotográficas obtenidas in situ, por cuyas razones me permito distraer su atención" Carta de Carlos Correa Luna a Roberto Lehmann-Nitsche, Buenos Aires, 27 de julio de 1902 (Legado Roberto LehmannNItsche, IAI, Berlin, N-0070 b
} 
Luego de estas primeras noticias sobre la expedición a La Esperanza y aproximadamente un año después de haber regresado de ese viaje, los resultados de la investigación se hallaban listos para ser publicados en los Anales del Museo de La Plata. En esa edición participaron dos grandes imprentas de la época. La impresión de los textos, cuadros, tablas y la encuadernación sería realizada por la imprenta de los hermanos Coni ${ }^{31}$, la cual se hallaba desde 1906 a cargo de la edición de la Revista y los Anales del Museo de La Plata (Cf. Buonocore, 1944: 5456). Para la impresión del atlas propiamente dicho, que iba a contar con 50 láminas ilustradas con las fotografías de indígenas chaqueños obtenidas en La Esperanza, Lehmann-Nitsche pensó en lograr el concurso de la casa imprentera de Werner y Winter en Frankfurt, Alemania ${ }^{32}$. La elección de este establecimiento estaba fundada en la calidad que tenían los trabajos gráficos allí realizados, a criterio no solo de Lehmann-Nitsche sino también de Carlos Bruch. En efecto, dos años más tarde, en 1909, cuando Carlos Bruch se ocupaba de la impresión de los resultados de sus viajes por el noroeste en 1907 y 1908 (ver capítulo II), se puso también en contacto con esta casa para confeccionar las ilustraciones que acompañarían ese trabajo, a la que consideraba "uno de los mejores establecimientos", además de afirmar que existían "ejemplos sobrados que comprueban que los trabajos de ésta índole, hechos en el país no solo resultan ser inferiores sino tanto ó mas costosos."33. Aunque estas tratativas dan la pauta de que se contaba con los fondos necesarios para emprender un trabajo editorial de costo relativamente alto, el director del museo optó por realizar las láminas ilustradas en el país, debido tal vez a los elevados montos del flete que implicaba su realización en el exterior.

De este modo, el trabajo de impresión de las láminas sería encomendado a la Compañía Sudamericana de Billetes de Banco, que confeccionaría las láminas

\footnotetext{
${ }^{31}$ Pablo Emilio Coni (1826-1910) arribó a Argentina procedente de Francia ejerciendo como librero impresor en Corrientes, trasladándose lego a la ciudad de Buenos Aires donde abrió su imprenta en la calle Perú, frente a la Manzana de las Luces. En 1887 se asociaron a la empresa sus hijos Fernando y Pablo, operando como Pablo Coni e hijos hasta 1899, y como Coni Hermanos hasta 1916, año en que Fernando se hizo cargo del negocio familiar y Pablo fundó y dirigió, hasta abril de 1929, la imprenta de la Universidad Nacional de Buenos Aires. Fue, junto con Casavalle, el editor de las primeras publicaciones periódicas de carácter científico y literario, como la Revista Farmacéutica (1863) -órgano de la Sociedad de Farmacia Nacional Argentina-, los Anales del Museo Público de Buenos Aires (1864), y los Anales de la Sociedad Científica Argentina (1876), entre otros (Buonocore, 1944: 54-56, citado en Farro 2009).

32 Lehmann-Nitsche se había puesto en contacto con esta imprenta el 27 de febrero de 1907 (Carta de Werner y Winter a Lehmann-Nitsche, Frankfurt am Main, 4 de abril de 1907, AHFMLP).

${ }^{33}$ Carta de Carlos Bruch a Samuel Lafone Quevedo, La Plata, 21 de abril de 1909 (AHFMLP).
} 
sobre "papel glacé especial para ilustraciones"34 cobrando por 500 ejemplares de cada una de las 50 láminas previstas la suma de \$30 (lo que daba un total de \$1500 por todas las láminas), además de una suma de \$0.09 por centímetro cuadrado por la "confección de los clichés autotipias ${ }^{35}$ en cobre, debidamente retocadas". Dado que cada lámina tenía una dimensión aproximada de $17 \times 23 \mathrm{~cm}$, el costo de preparación de cada una de ellas sería de $\$ 35^{36}$. El día 6 de octubre de 1907 Samuel Lafone Quevedo, por el Museo de La Plata y Emérico Mangel, en representación de la Compañía Sudamericana de Billetes de Banco firmaban en Buenos Aires el contrato para realizar este trabajo de impresión ${ }^{37}$. Ese mismo día, las 50 planchas destinadas a los Anales fueron recibidas por la imprenta ${ }^{38}$.

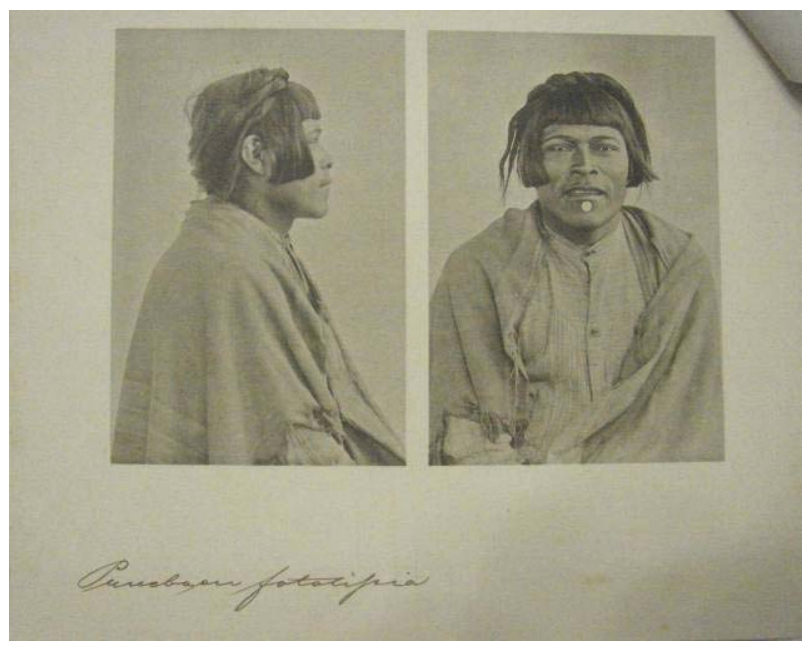

Figura 6. "Prueba en fototipia". ("Presupuesto", Cía Sud. de Billetes de Banco, 14/09/1907, AHFMLP)

Esta prueba en fototipia fue enviada por la Cía Sudamericana de Billetes de Banco al Museo de la Plata cuando se hallaban en tratativas para definir el proceso fotomecánico a utilizarse para la reproducción de las láminas. El museo optaría finalmente por la autotipia, cuyo costo era menor que la impresión por medio de la fototipia.

De acuerdo a lo convenido la imprenta se encargaría de desarrollar los clichés en cobre y en autotipia, tarea que se iba a realizar a partir de las planchas entregadas

\footnotetext{
${ }^{34}$ Convenio celebrado entre el Museo de La Plata y la Compañía Sudamericana de Billetes de Banco, 6/10/1907 (AHFMLP).

${ }^{35}$ Este proceso de impresión fotográfica fue desarrollado por el fotograbador alemán Georg Meisenbach (18411912) hacia 1881, y consistía en la preparación de una plancha de impresión a partir de su exposición a través de dos planchas de vidrio muy finamente rayado que convertía cualquier escala de grises en pequeños cuadrados de diferente diámetro. El socio de Meisenbach, Josef Ritter von Schmaedel, llamó a este procedimiento "proceso de autotipia". La primera publicación que utilizó el proceso de autotipia fue el catálogo de la exhibición de electricidad en Munich en 1882 (Hannavy 2008: 960).

${ }^{36}$ Esto daría un total de $\$ 1750$ por la preparación para la autotipia de las 50 láminas lo que sumado a los $\$ 1500$ de costo por la reproducción de 500 ejemplares, arroja un total aproximado de $\$ 3250$ solamente por la impresión del atlas. A esto debemos sumar luego el costo de impresión del texto escrito, dibujos, tablas, la compaginación y la encuadernación que serían realizados por la imprenta de los hermanos Coni. Para dar una idea del valor relativo de esta suma tengamos en cuenta que para fines de 1905, cuando el museo estaba aún bajo administración provincial, la asignación mensual para toda esa institución era de \$4300, de la cual el $88 \%$ (\$3784) estaba destinada al pago de los sueldos (García 2010: 146).

${ }^{37}$ Convenio celebrado entre el Museo de La Plata y la Compañía Sudamericana de Billetes de Banco, 6/10/1907 (AHFMLP).

${ }^{38}$ Memorándum, Compañía Sudamericana de Billetes de Banco, 6/10/1907 (AHFMLP).
} 
por el museo. En muchos casos estas planchas serían realizadas directamente a partir de los negativos originales, aunque en otros casos, debido a la disposición de las imágenes pensada por Lehmann-Nitsche para esa publicación y que más adelante veremos en detalle, se requería una reducción y un nuevo arreglo de ciertas imágenes $^{39}$. Aunque no contamos con información específica al respecto es muy probable que haya sido Carlos Bruch quien se encargó de realizar estos trabajos, dado su experiencia anterior como fotógrafo y fototipista de los talleres de impresión del museo hasta el 1900. A pesar de que esos talleres ya no funcionaban en el museo ${ }^{40}$, para poder desarrollar las planchas de la forma deseada Bruch contaba con las instalaciones del laboratorio fotográfico que funcionaba desde algunos años atrás en la azotea del museo $^{41}$ (Figura 7).

Figura 7. (C. Bruch, 1907, Negativo de vidrio $18 \times 24 \mathrm{~cm}$., AFO-002-001-008-0002, AHFMLP).

En esta imagen puede observarse como preparó Bruch las planchas que fueron dadas a imprenta. En este caso, al copiar en papel fotográfico los dos negativos de vidrio de $18 \mathrm{X}$ $24 \mathrm{~cm}$. que contenían, cada uno de ellos, las fotos de frente y de perfil de los dos indígenas que aparecen retratados (tomadas ambas posturas en un solo negativo mediante una técnica que veremos más adelante) los redujo en tamaño, aproximadamente a la mitad, pegó las copias en una cartulina blanca a la que colocó sobre una superficie plana de la forma que podemos apreciar en esta figura y las fotografió, obteniendo un nuevo negativo en $18 \times 24 \mathrm{~cm}$. a partir del cual se realizarían las láminas incluidas en los Anales del Museo de La Plata de 1907

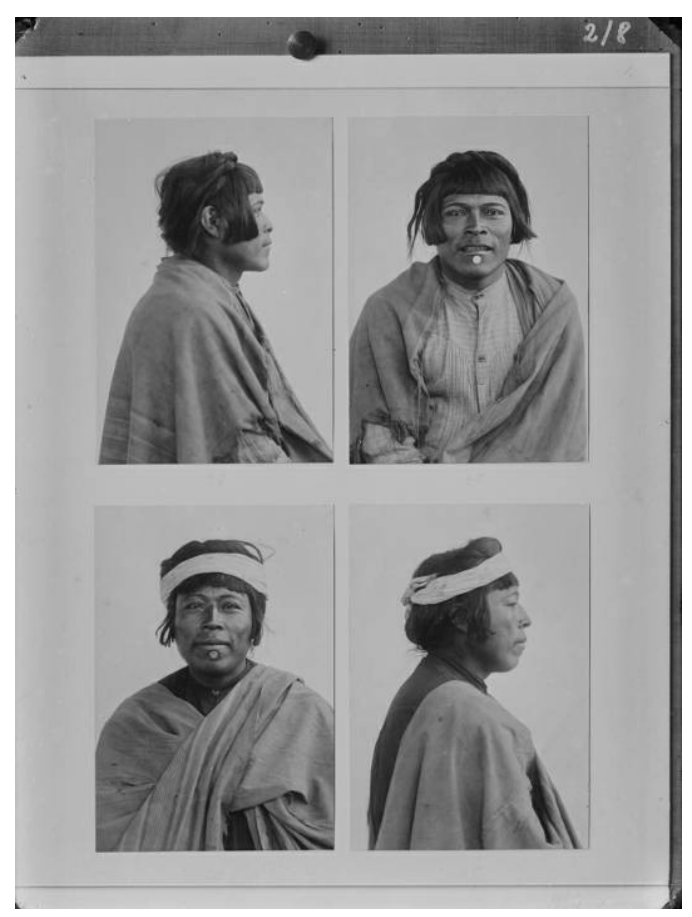

\footnotetext{
${ }^{39}$ Carta de Werner y Winter a Lehmann-Nitsche, Frankfurt am Main, 4 de abril de 1907 (AHFMLP).

40 El 25 de enero de 1906 se realizó la entrega del museo a la administración nacional con todo lo contenido en él, a excepción de: " $1^{\circ}$ El taller de impresiones oficiales; $2^{\circ}$ La colección de cuadros del Dr. Sosa; $3^{\circ}$ La primera locomotora del F.C. del Oeste llamada "La Porteña"; $4^{\circ}$ Un armario de colecciones entomológicas depositadas por el Sr. José Steinbach; $5^{\circ}$ Colección de objetos calchaquíes depositada por el Dr. Samuel Lafone Quevedo; $6^{\circ}$ Los duplicados de revistas estrangeras pertenecientes al Dr. F. P. Moreno" (Ministerio de Obras Públicas de la provincia de Buenos Aires Letra $\mathrm{M} \mathrm{N}^{\circ} 31$, AHPBA)

${ }^{41}$ Un informe sobre el estado del los talleres de impresión del museo realizado por su director, Alfredo Wilcke, el 17 de abril de1903 decía: La galería de la fotografía por su mala ubicación, no presta el servicio que debe, por falta de luz y su mucha vibración, motivada por las transmisiones que ponen en movimiento las máquinas impresoras. El piso de la fotografía está situado a 2.30 metros debajo de las claraboyas, lo que motiva, que este departamento no reciba suficiente luz por los costados, lo que constituye un gran defecto para las exposiciones fotográficas. Sería pues necesario su traslación a la azotea del Museo." (Ministerio de Obras Públicas de la provincia de Buenos Aires, Letra M N 124, AHPBA)
} 
En los Anales de 1907 pueden encontrarse un total de 30 láminas que contienen 4 fotografías confeccionadas de la misma forma en que se realizó la lámina de la Figura 7; otras 4 láminas incluyen 3 fotos, luego hay 7 láminas con 2 fotos, y el resto, 9 láminas, llevan solo una fotografía estampada. De esta forma el número total de fotografías publicadas en esa ocasión se eleva a 155, donde pueden hallarse retratadas 112 personas, pertenecientes a los pueblos indígenas chaqueños que se hallaban en ese momento en el ingenio. Al igual que lo había hecho al editar la colección de fotografías indígenas de Boggiani, Lehmann-Nitsche ordenó las descripciones y fotografías utilizando criterios cada vez menos inclusivos. En primer lugar los registros se agruparon según el pueblo indígena al que pertenecieran las personas examinadas, ubicando en primer lugar a los chiriguano, luego a los chorote, y finalmente mataco y toba ${ }^{42}$. Luego, ya dentro de esos cuatro grandes grupos se colocaron en primer lugar los datos descriptivos y fotografías de los hombres, seguidos por los de las mujeres. Esta vez el ordenamiento no pasó de ese punto ya que, en contrario a lo realizado con la colección Boggiani, no se utilizó la edad de las personas retratadas como criterio para disponer sus imágenes y descripciones.

Cada una de esas fotografías iba a acompañada de una leyenda numérica que relacionaba la imagen con una descripción que se encontraba en el texto que antecedía a las láminas. Esta descripción incluía en primer lugar el número dado al retratado, su nombre, edad, lugar de origen, cutis, iris, cabello y dentadura en todos los casos, agregándose generalmente y luego de esos datos algún rasgo destacable, como los tatuajes, para dar cuenta de estos últimos se incluyeron unas series de dibujos que daban cuenta de los diseños principales.

Junto con las ilustraciones y sus respectivas descripciones, otra parte destacable de la publicación estaba conformada por una extensa sucesión de cuadros y tablas donde se expresaban los resultados de las mediciones y de los índices, medias y valores relativos resultantes a partir de los datos en bruto obtenidos en el campo,

\footnotetext{
${ }^{42}$ Este orden parece coincidir en principio con el orden en que se realizaron las investigaciones en el terreno. En carta del 6 de agosto de 1906, Bruch y Lehmann-Nitsche le dicen al director del museo que ya habían "medido y rotulado" a 35 chiriguanos y se hallaban haciendo lo mismo entre los chorotes, en tanto para estudiar a matacos y tobas, Walter Leach les había aconsejado trasladarse hasta el lote San Antonio. (Carta de Robert LehamnnNitsche y Carlos Bruch a Samuel Lafone Quevedo, La Esperanza, 6 de agosto de 1906, AHFMLP)
} 
fueron en total 63 cuadros que ocuparon 50 páginas, desde la página 100 hasta la 149. Para realizar las estadísticas Lehmann-Nitsche contó con la colaboración del ayudante de la sección, "el estudiante Raffaelli" quien "prestó buenos servicios (...)

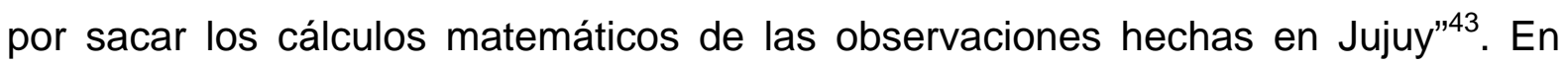
este sentido, tal como marcábamos al inicio de este capítulo y siguiendo a García (2005), al incorporarse el museo a la universidad los antiguos investigadores que estaban a cargo de algunas de las secciones de aquella institución, como es el caso de Lehmann-Nitsche, fueron nombrado en la doble función de profesores titulares y jefes de sección. Por otra parte, debido al número reducido de alumnos, algunas cátedras dictaban sus clases en los gabinetes de estudio de los mismos profesores, donde aprovechaban las colecciones y los materiales exhibidos para ilustrar sus clases (García 2005: 36). Como marca esta autora, en materias como antropología se encomendaba a los ayudantes-alumnos la realización de láminas de gran formato ("mapas murales") que incluían figuras esquemáticas extraídas de distintas obras. Estos alumnos podían además, y como en el caso del "estudiante Raffaelli", colaborar en las llamadas "tareas de gabinete", representando un temprano ejemplo de una práctica aún vigente.

\section{De la fotografía "antropológica" a la fotografía "artística"}

En el capítulo anterior vimos como Lehmann-Nitsche intentó conjugar dos modos de aplicar la fotografía a la antropología, dos modos de ver bien diferenciados. Uno de ellos, que le había sido presentado en 1900 por el antropólogo alemán Gustav Fritsch, apelaba como vimos a la experticia y el entrenamiento en la observación del investigador, y su éxito se basaba fundamentalmente en la capacidad de discernimiento y estabilización de los objetos científicos adquirida por medio del mismo hábito de observar. No se requería el uso de instrumentos ni procedimientos diseñados especialmente para tal fin, tan solo hacía falta contar con una serie de fotografías, cuyas condiciones de producción bien podían ser desconocidas para el observador, dispuestas sobre una superficie que permitiera poder observar todo el conjunto con un solo golpe de vista. El otro enfoque, de corte más cuantitativo, había sido formulado por académicos de la Escuela de Antropología de Paris en

\footnotetext{
43 "Informe de la sección antropo- y etnológica desde el $1^{\circ}$ de Febrero hasta el 31 de diciembre de 1906" (AHFMLP)
} 
1898 y formulaba una serie de pasos a seguir para obtener fotografías que tuvieran "valor científico". Esta propuesta, a diferencia de la anterior, ponía énfasis en el modo de producción de las imágenes fotográficas. Subrayando la necesidad para los estudios de antropología física de obtener retratos de desnudos, sugería desde el formato ideal de las placas a utilizar hasta las posturas que debían tomar los modelos, pasando por la escala que debían respetar las imágenes e indicando incluso la utilización de una regla métrica junto a los retratados, para dar una idea de sus proporciones.

Un tiempo después de que estas últimas indicaciones metodológicas fueran formuladas, durante el año 1903, una expedición científica francesa llegaba a Sudamérica con el objetivo efectuar un completo y extenso estudio sobre el Altiplano boliviano y los pueblos indígenas (quechuas y aymaras) que lo habitaban $^{44}$. Esa misión había sido encargada por el Ministerio de Instrucción Pública de Francia a los señores G. Crequi Monfort y E. Senechal de La Grange. El estudio de la antropología de los habitantes del altiplano estaría a cargo del antropólogo Arthur Chervin (1850-1921) quien sin embargo permanecería en Francia enviando a un fotógrafo, el Sr. Julien Guillaume, recomendado por Alphonse Bertillon (1853-1914) ${ }^{45}$, que se encargaría de la antropometría y las fotografías "métricas" utilizando el aparato fotográfico diseñado por el mismo Bertillon y siguiendo las indicaciones de Chervin. El antropólogo permanecería en la ciudad, esperando contar con los datos que le serían entregados por el fotógrafo-viajero (Cfr. Giraudo y Arenas 2004). Para Chervin, al igual que para Lehmann-Nitsche, la imagen fotográfica representaba una ventaja en términos económicos con respecto a las descripciones escritas "mi estudio ha sido agradablemente facilitado por una muy abundante cosecha de fotografías que constituyen documentos pintorescos de

\footnotetext{
${ }^{44}$ Como resultado de esta misión se publicaron doce volúmenes donde se trataron en forma separada las distintas clases de estudios llevados adelante. Un primer volumen ofrecía un informe general de la misión, en el segundo se incluían los mapas levantados, el resto de los volúmenes trataron del estudio de los lagos, la antropología, lingüística, geología, arqueología, zoología, fisiología, paleontología y geografía (Chervin 1908).

${ }^{45}$ Alphonse Bertillon (París, Francia 1853 - Münsterlingen, Suiza 1914) fue un funcionario policial francés hijo del antropólogo, médico y estadístico Louis-Alphonse Bertillon y hermano de Jacques Bertillon quien también fue médico y estadístico. Bertillon aplicó la antropometría para la identificación de criminales y hacia fines de la década de 1880 diseñó un sistema de identificación que incluía fotografías de frente y perfil tomadas desde distancias determinadas y a una escala constante. Diseñó además una silla especial para lograr que los retratados conserven una postura homogénea (Ver Figura X). Su método de identificación, si bien tuvo amplia aceptación a nivel internacional cayó en desuso hacia fines de la década de 1890, con la aparición del sistema dactiloscópico formulado por Francis Galton en Inglaterra y Juan Vucetich en Argentina.
} 
primer orden y dispensan de largas, difíciles y sin embargo siempre insuficientes descripciones literarias." (Chervin 1908: xi).

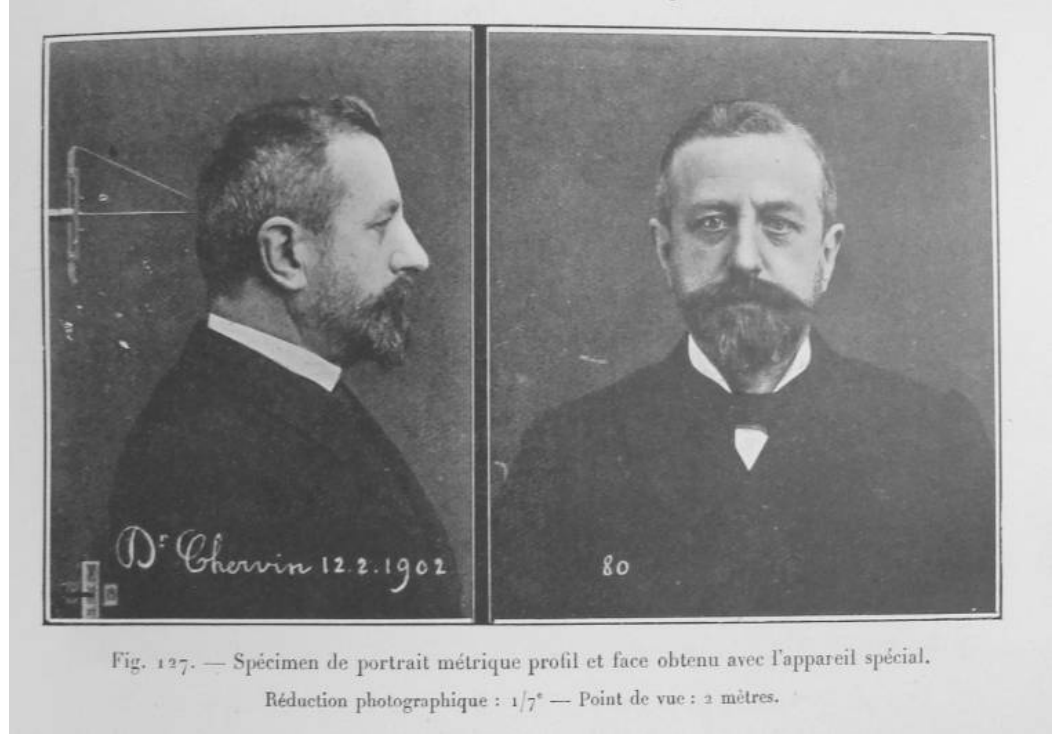

Figura 8. "Espécimen de retrato métrico frente y perfil obtenido con el aparato especial. Reducción fotográfica $1 / 7$ - Punto de vista 2 metros" (Chervin 1908: 295).

Esta imagen, tomada el 12 de febrero de 1902 donde aparece retratado Arthur Chervin es un ejemplo de lo que ese autor llamó "fotografía métrica" y que combinaba los principios fotográficos aplicados por Bertillon con otros de su invención.

Las fotografías tomadas por esta misión y que Cervin denominara "métricas", se distanciaban tanto de los retratos de estudio como de las fotografías "pintorescas" o de "vistas" en forma muy clara. Estas últimas no presentaban para él "ningún valor científico, sobre todo desde el punto de vista antropológico" ya que habían sido hechas "sin método, sin regla, sin precisión, en una palabra sin ninguno de las precauciones que permiten hacerlas comparables entre ellas." (Chervin 1908:xix) Distanciándose en esa forma de una fotografía casual y pintoresca Chervin buscaba producir fotografías que funcionaran del mismo modo que una carta geográfica, debiendo indicar la relación entre las dimensiones de la imagen con respecto al objeto representado por intermedio de una escala proporcional. Ya que para él la cartografía "comenzó a adelantar y a hacerse una verdadera obra científica sólo cuando la indicación de la escala proporcional permitió situar y representar exactamente las posiciones geográficas. Resultará lo mismo para la fotografía aplicada sobre todas las manifestaciones de la biología." (Chervin 1908:xx, mi traducción) Por otra parte, las reglas que Chervin había formulado para esta fotografía eran extensas y detalladas, superando en rigurosidad aquellas enunciadas por Mortillet y Fourdignier en 1898 (Mortillet 1898, Fordrignier 1898, Chervin 1908: 293-334). 
Figura 9. Aparato de Bertillon utilizado para la fotografía métrica por la misión francesa al altiplano boliviano.

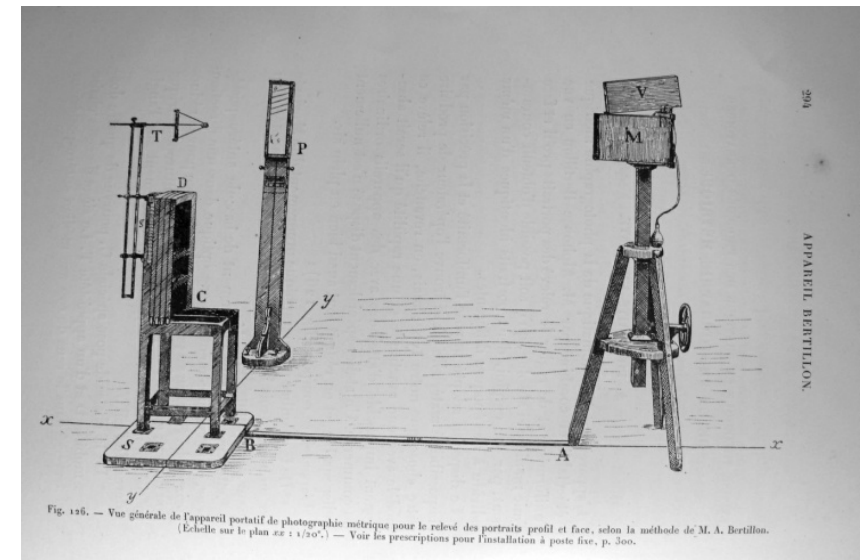

Uno de los principales problemas que tenía la aplicación de la fotografía métrica en el campo era el traslado del aparato fotográfico diseñado por Bertillon (Figura 9), para Chervin sin embargo, esto no traía mayores inconvenientes ya que una sola mula podía transportarlo y podía ser embalado, desembalado e instalado en pocos minutos. Lehmann-Nitsche, en el informe presentado luego de su viaje por Europa en $1900^{46}$, declaraba que "para la fotografía antropológica obtuve no solamente los instrumentos mejor construidos actualmente, sino que modifiqué también el de Bertillon, simplificándolo para los viajes. Creo que será la primera vez que se emplean los aparatos de Bertillon para el estudio de la Antropología". Como esto había sucedido luego de su trabajo con los takshik la próxima ocasión que tendría ese antropólogo utilizar este aparato fotográfico sería justamente en el viaje al ingenio La Esperanza. Sin embargo desistió de ello ya que, contrariamente a lo que había planteado no sólo Chervin sino también él mismo, la silla de Bertillon no era "apta para llevar en viajes" (Lehmann-Nitsche 1907a: 56). En vez de utilizar esa silla Lehmann-Nitsche sostuvo que "en todas nuestras operaciones fotográficas, la máquina y el indígena se colocaban en el mismo lugar, y los retratos resultaron así de la misma reducción" (Lehmann-Nitsche 1907a:56) Una vez que hubo publicado este trabajo le envió una copia a Chervin quien, aunque agradecido por el envío, lamentaba que Lehmann-Nitsche no haya llevado consigo el aparato de Bertillon "que es tan fácil de transportar en viaje y que tiene la gran ventaja de producir

\footnotetext{
46 "Informe sobre un viaje a Europa efectuado durante el segundo semestre del año 1900. Presentado al Señor Director del Museo de La Plata, por el Dr. Robert Lehmann-Nitsche, encargado de la sección antropológica". (AHPBA)
} 
fotografías a una escala conocida. Usted bien dice que todos sus retratos fueron tomados a la misma escala, pero no dice cual es esa escala."47 (Figura 10)

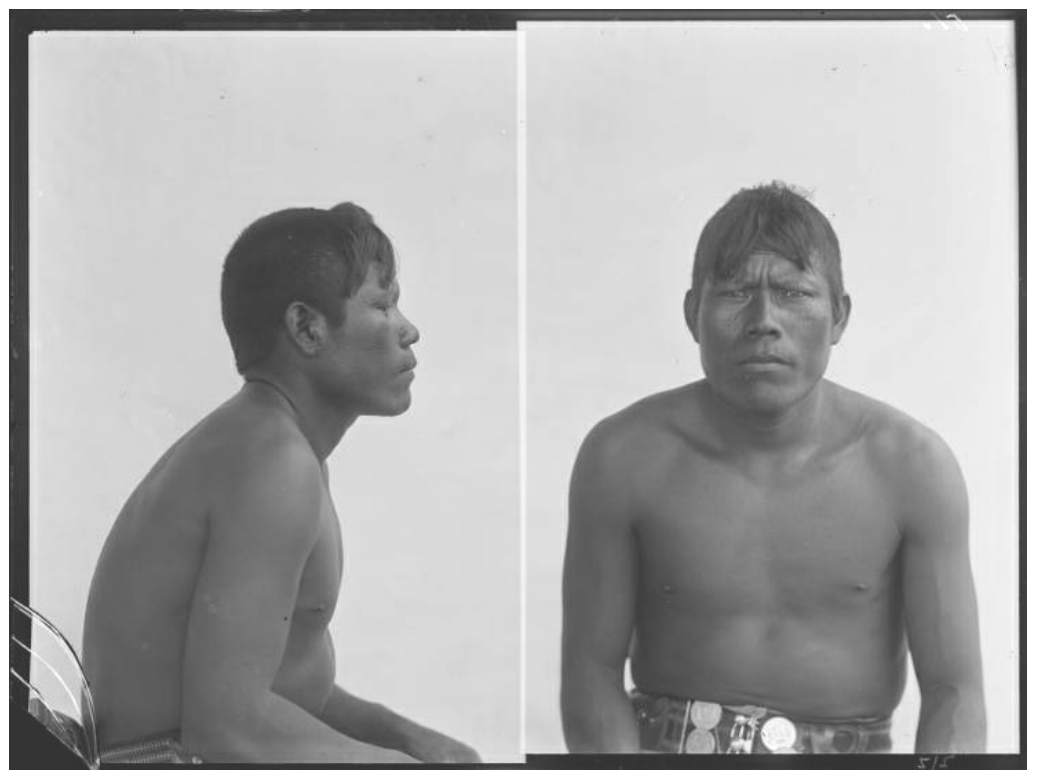

Figura 10. C. Bruch, 1906, ingenio La Esperanza, Jujuy. (AFO-002-001005-0005, AHFMLP)

En esta imagen puede notarse la diferencias entre la postura adoptada por esta persona especialmente en la toma de perfil y la adoptada por la persona retratada en la figura $X$ ayudada por el aparato de Bertillon.

En este sentido, Chervin se mostraba muy crítico hacia los modos de producción de fotografías antropológicas por parte de los académicos alemanes. En su libro Anthropologie Bolivienne, hace referencia a un atlas antropológico con fotografías de indígenas de Melanesia y el sudeste de Asia ejecutadas por el Dr. Bernhard Hagen $^{48}$, y editadas por la librería Fritz Lehmann, de Stuttgart. Según su autor esas fotografías estaban destinadas tanto a artistas como anatomistas, antropólogos y etnólogos. Sin embargo para Chervin ellas "no son buenas para unos, ni para otros, porque carecen de calidades esenciales e indispensables para un uso científico" (Chervin 1908: xxi), ya que esas fotografías no satisfacían ninguna de las condiciones de la antropología métrica de Bertillon: la cabeza no estaba derecha y el sujeto miraba de soslayo, y las fotografías carecían de escala, lo que no permitía conocer la reducción en la que habían sido ejecutadas.

\footnotetext{
${ }^{47}$ Carta de Alphonse Chervin a Robert Lehmann-Nitsche, Paris, 20 de marzo de 1910 (Legado Robert LehmannNitsche , IAI, Berlin, N-0070 b125)

${ }^{48}$ Kopf- und Gesichtstypen ostasiatischer und melanesischer Völker: Atlas mit 50 Doppeltafeln nach eigenen Aufnahmen mit Einleitung und erklärendem Text, Lehmann: Stuttgart, 1905.
} 
Figura 11. "Tuyuka” (T. Koch Grunberg 1906: 31)

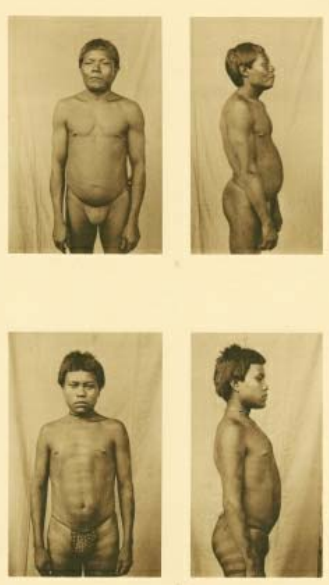

En forma similar se expresaba Chervin sobre los atlas antropológicos de los indígenas amazónicos publicados por el Dr. Theodor Koch-Grünberg ${ }^{49}$, señalando que no eran "más que una publicación simple y pintoresca para uso de la gente de mundo, ya que no han sido ejecutadas en condiciones métricas que permiten darle el valor de un documento científico serio." (Chervin 1908: xxi) Por su parte este último autor ponía en duda la utilidad de una aproximación métrica para el conocimiento de las razas humanas, al sostener que

"sin menospreciar aquí de manera alguna las mediciones sobre el cuerpo, sin embargo, me gustaría unirme a las palabras de Baelz" "Una buena y sencilla imagen a menudo dice, para nosotros los etnógrafos, más que volúmenes enteros de mediciones" Por lo tanto, creo, con esta colección de tipos en los cuales varias tribus se hallan representadas por numerosos retratos, cumplir un servicio también para los antropólogos." (Koch-Grünberg 1906:1, mi traducción)

Una década después de realizado este trabajo, ya alejado de los estudios antropométricos, decía Lehmann-Nitsche acerca de este modo de fotografiar y de ver que había predominado en la antropología de finales del siglo XIX y principios del siglo XX:

"Impera la costumbre de fotografiar la figura de una persona como un cuerpo estereométrico, como un cristal, por ejemplo, en posición rígida, de frente, de perfil y

\footnotetext{
49 "Indianertypen aus dem Amazonasgebiet. Nach eigenen Aufnahmen während seiner Reisen in Brasilien"(1906-1911)

${ }^{50}$ Erwin Otto Eduard von Bälz (1849-1913), médico y antropólogo alemán que se desempeñó durante 27 años como médico personal de la familia imperial japonesa. Entre 1899 y 1903 realizó algunos estudios etnológicos en la actual Corea del Sur.
} 
de espalda; y a ser posible en determinada reducción: 1/7 del tamaño natural. Háse creído, bajo la influencia de la escala métrica, que tales fotografías podrían servir, al mismo tiempo, para medir sobre ellas las dimensiones y proporciones del cuerpo. Háse intentado de este modo reunir, simultáneamente, dos ilustraciones para el estudio antropológico: la antroposcópica y antropométrica. Hoy se sabe empero, que en este terreno no es posible hacer dos cosas a la vez; y que sólo en casos excepcionales una fotografía hecha con fines fisiognómicos, podría servir simultáneamente para indicar medidas y proporciones." (Lehmann-Nitsche 1977 [1916]:78-79)

En este sentido puede observarse que a diferencia de lo que ocurriera en ocasión de estudiar a los takshik, esta vez no se advierte en las fotografías la presencia de una escala métrica junto a los retratados y, como acabamos de señalar, aunque Lehmann-Nitsche señala que todas las fotografías habían sido tomadas utilizando la misma escala no indica cual era esa escala. Estos cambios en el modo de retratar indican que por una parte que las fotografías tomadas en La Esperanza fueron producidas con una menor rigurosidad debido a la ausencia de estos elementos métricos y de una escala uniforme de las imágenes. En ese sentido puede afirmarse que Lehmann-Nitsche estaba alejándose en cierta forma de lo que él llamaba "relevamientos matemáticos", los cuales, "sacados de frente y de lado, para representar al indígena con exactitud, en la misma proporción (á pesar de ser procedimiento técnico que se efectúa admirablemente por medio de la silla fotográfica de Bertillon), no alcanzan á ser del todo eficaces, y hay que combinarlos oportunamente con relevamientos verdaderamente "artísticos" en tres cuartos perfil, etc." (Lehmann-Nitsche 1907a:55).

De modo tal que, en 1906, a pesar de que seguiría utilizando las posturas clásicas para las fotos antropológicas (Ver Introducción), comenzaba a buscar nuevos puntos de vista. En ese sentido fue que los retratos de desnudos, de frente y perfil, y de cuerpo entero, se combinaron con otro tipo de láminas cuyo encuadre y composición diferían de lo esperado para una fotografía antropométrica. Esta inclusión fue realizada en forma deliberada, para componer un atlas que no provocara el "cansancio" que quienes lo estudiasen (Lehmann-Nitsche, 1907a: 55). Debido a estas licencias el atlas de 1907, no se reduce a una muestra puramente 
antropométrica. Allí el científico se distanciaba de los usos más comunes de la fotografía en la antropología física de fines del XIX, buscando ofrecer una mirada que rompía con los formatos preestablecidos en ese campo. Dice Lehmann-Nitsche que en esta oportunidad "para conseguir algo de variedad y para no cansar la vista, hemos alternado los relevamientos matemáticos con otros de índole artístico y con fotografías de busto, con toras de medio ó tres cuartos cuerpo" ${ }^{51}$. (Lehmann-Nitsche 1907a: 55)

Del mismo modo que el encuentro con Gustav Fritsch en Berlín influyó sobre la disposición de las imágenes de los Takshik en la publicación de 1904, es posible argumentar que la edición y comentarios que realizó ese mismo año sobre las celebradas fotos del artista y etnógrafo italiano Guido Boggiani pueden haber actuado en ese mismo sentido. En el capítulo anterior nos ocupamos con cierto detenimiento de la llamada colección Boggiani y los conflictos que se dieron entre Lehmann-Nitsche y Alberto Vojtech Fric y que tuvieron a esa colección como principal objeto de disputa. Aquí volvemos sobre Boggiani aunque enfocándonos más bien en el papel que jugó la obra fotográfica de este artista y explorador en la concepción que Lehmann-Nitsche tenía de la fotografía antropológica.

El trabajo fotográfico de Boggiani había impresionado en buena medida a LehmannNitsche, quien señalaba que esas fotografías no habían sido hechas de acuerdo a los principios antropológicos dominantes sino que para ellas primaba otro principio de validez, el artístico (Lehmann-Nitsche 1904c, 1904d). Esto, sin embargo, no era para él un defecto, contrariamente a ello, las fotografías de Boggiani le resultaban "naturales y llenas de vida" en oposición a las rígidas fotografías antropológicas, yendo aún más lejos en su apreciación se preguntaba si tal vez estos principios aplicados por Boggiani no darían "ideas completamente nuevas a la antropología y especialmente a la fotografía antropológica." (Lehmann-Nitsche 1904d). Yendo aún más allá en su apreciación de la obra de ese artista decía, algunos años más tarde:

\footnotetext{
${ }^{51}$ La vista de 3/4 cuerpo, que en lenguaje cinematográfico se conocen como "plano americano", "corta" a los retratados hacia la mitad de los muslos, y es muy utilizado en el cine, permitiendo advertir en el personaje ciertos detalles como la mirada y la expresión facial, al tiempo que da un buen lugar a la relación de la figura con su entorno revelando lo esencial del cuerpo y como está plantado, dando la impresión de cierta totalidad (Russo 1998:198).
} 
"Acaso Boggiani no se inquietó de estos detalles, pero el hecho es que al retratar a sus indios, dejándose guiar simplemente por su instinto de artista, consiguió reproducciones llenas de vida, llenas de belleza, llenas de expresión, reproducciones que impresionan y encantan a quien sabe sentir" (Lehmann-Nitsche 1977 [1916]:79)

Es posible identificar varios paralelismos entre las fotografías tomadas por Boggiani en el Chaco paraguayo y aquellas obtenidas por Bruch y Lehmann-Nitsche en el ingenio La Esperanza. Estos paralelismos ocurrieron en distintos niveles, y que afectaron incluso elecciones materiales. Por ejemplo, mientras en 1899 Bruch y Lehmann-Nitsche habían utilizado negativos de vidrio en formato $13 \times 18 \mathrm{cms}$., siguiendo las recomendaciones de Fourdrignier (1898), en esta ocasión llevaron consigo varias docenas de negativos de $18 \times 24 \mathrm{cms}$., la misma medida de los negativos fotográficos que Boggiani había mostrado a Lehmann-Nitsche durante su estadía en Buenos Aires en 1900. Otro de los puntos en común entre ambos trabajos está representado por los fondos utilizados para tomar las fotografías. En ambos casos puede observarse que si bien a veces se utilizaron telones o se aprovecharon las paredes de algún edificio para obtener un fondo neutro, en otras ocasiones se optó por brindar una imagen del contexto de fondo si intentar disimularlo. Por otra parte los corrimientos, cortes y desplazamientos, con respecto a las posturas de los modelos y encuadres fotográficos preestablecidas en la antropología, que Boggiani practicaba en sus propias imágenes resultaron una novedad para Lehammn-Nitsche quien buscó obtener imágenes en ese sentido, por lo que no sería erróneo entender que la combinación ensayada por LehmannNitsche entre lo que él llamó "relevamientos matemáticos" con los "relevamientos artísticos" puede relacionarse con una búsqueda propiciada a partir de su encuentro con el trabajo fotográfico de Guido Boggiani. 


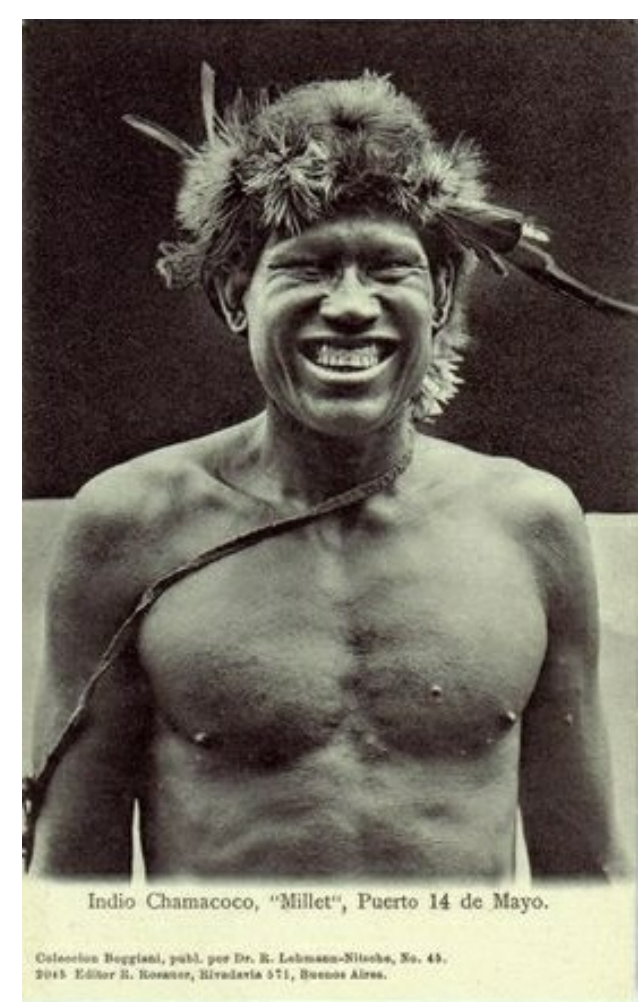

Figura 13. "Huaiki, 20 años, del norte del Pilcomayo" (C. Bruch 1906, Ingenio La Esperanza, Jujuy) (AFO-002001-046-0009, AHFMLP)
Figura 12. "Indio Chamacoco, "Millet", Puerto 14 de Mayo (Colección Boggiani, Museo Andrés Barbero, Asunción)

"Ahora es el indio "Millet" que también ríe a carcajadas (...) Podría afirmarse, que esta fue la primera vez que se fijó en la placa fotográfica, con intención, la risa del hombre primitivo, esta exteriorización de su alma, de su verdadera y oculta vida íntima... ¡Y cómo sabe reír el indio! Nadie lo diría, sin ver primero las ilustraciones de Boggiani. El indio, según el concepto vulgar, es indiferente, es frío, es incapaz de sentir íntimamente, es incapaz de manifestar su pobre vida psíquica...

Hoy, merced a Boggiani, conocemos sin embargo, la risa del indio, una risa divina, libre, franca...

¡La genialidad de un artista supo revelarnos el alma de estos hijos humildes de la naturaleza!"(Lehmann-Nitsche 1977[1916]: 79-80)

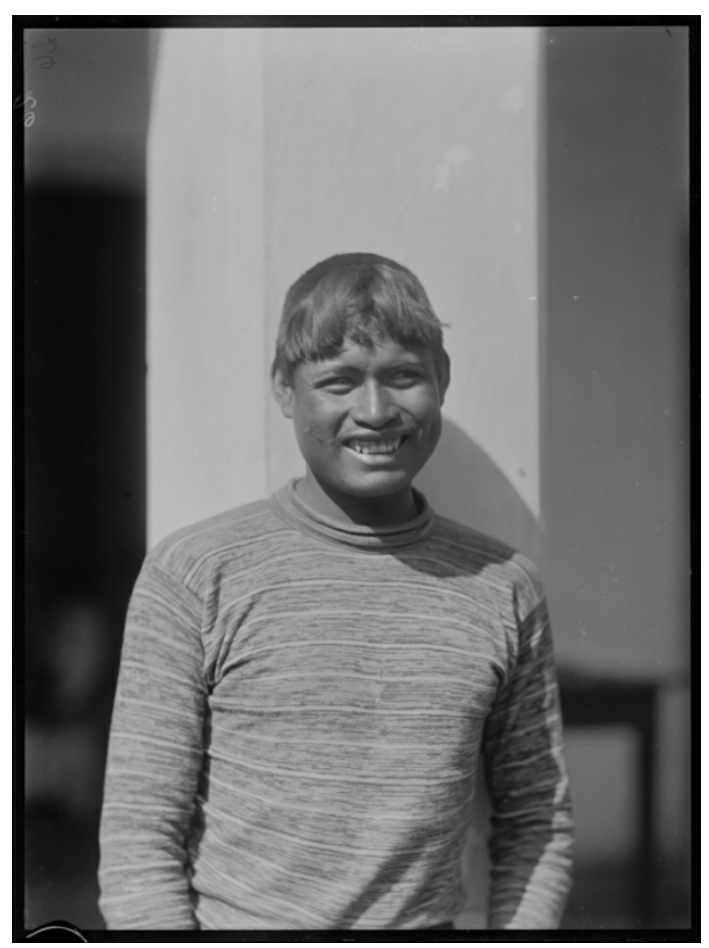

En este punto resulta significativo recordar las afirmaciones de Mariana Giordano en relación a las consideraciones que Lehmann-Nitsche tuvo acerca de la fotografía de Boggiani:

"Es decir, para Lehmann Nitsche las tomas en diversas poses del mismo personaje podrían ser utilizadas científicamente pero no se ceñían estrictamente a las normativas de la fotografía antropométrica que era la que a él particularmente le interesaba; aunque reconocía el alcance científico de estas imágenes, además de su valor artístico. Estas apreciaciones son propias del contexto epistemológico que sustentaba la ciencia antropológica del siglo XIX y principios del XX, donde cualquier reacción estetizante invalidaba el registro antropológico." (Giordano 2004) 
En primer lugar como pudimos ver tanto en este capítulo como en el anterior, si bien Lehmann-Nitsche había intentado utilizar la fotografía antropométrica en ocasión de estudiar a los takshik, rápidamente había cambiado el rumbo interesándose más por desarrollar una mirada que él mismo llamaría, más tarde, como "antroposcópica" y que buscaba capturar lo esencial de un grupo humano a través de un golpe de vista. Este modo de ver, sin embargo, no requería de rigurosidad alguna en la producción de las imágenes sino que incluso demandaba un cierto desplazamiento de esas pautas. En consecuencia no sería correcto pensar, al menos en todos los casos, que las "reacciones estetizantes" invalidaban el registro antropológico, ya que, como acabamos de marcar, si eso era cierto para la academia francesa, no lo era para los antropólogos de la escuela alemana como Gustav Fritsch, Theodor Koch-Grunberg y el mismo Lehmann-Nitsche.

\section{El fin de la serie de "estudios y relevamientos antropológicos"}

A pesar de este entusiasmo por lo que prometía ser un nuevo impulso para la fotografía antropológica, el trabajo realizado por Bruch y Lehmann-Nitsche en La Esperanza sería el último aporte de cierta envergadura que en ese campo fuera emprendido por esos investigadores y desde el Museo de La Plata. En 1908, con la publicación de los resultados de las observaciones antropológicas efectuadas un año antes sobre Damiana, la indígena aché que había sido traída a La Plata por ten Kate y La Hitte en 1897, Lehmann-Nitsche daba fin a la serie de estudios y relevamientos antropológicos que iniciara en 1898 en la Exposición Nacional de Buenos Aires ${ }^{52}$. Y junto con ello concluía una etapa signada por la estrecha relación establecida entre los estudios de antropología física y el dispositivo fotográfico. Si bien este antropólogo siguió utilizando la cámara en sus viajes de campaña, las fotografías que tomó durante esos viajes no fueron publicadas ni utilizadas de la forma en que lo hizo en los trabajos que aquí analizamos. Además, aunque en sus publicaciones sobre el folklore rioplatense se valió de gran cantidad de imágenes, estas tenían un carácter meramente ilustrativo.

\footnotetext{
52 Aunque algunos de estos relevamientos no fueron publicados sino hasta 1916 para ese momento LehmannNitsche había abandonado las investigaciones en antropología física y se hallaba enfocado en los estudios del folklore rioplatense y de la mitología y cosmología de los indígenas del gran Chaco.
} 
En el contexto de los estudio de antropología física que se venían llevando a cabo alrededor del mundo desde la segunda mitad del siglo XIX la fotografía se había mostrado no sólo como un instrumento útil y versátil a la hora de proveer a los investigadores con nuevos datos, sino también ella fue en sí misma considerada como una forma válida de acceso al conocimiento de la diversidad humana (Spencer 1992, Naranjo 2006). Sin embargo, esta situación iría cambiando paulatinamente hacia las primeras décadas del siglo XX; tal como afirma Elizabeth Edwards, quien se refiere al caso de la antropología anglosajona, en ese momento se produjo el ocaso del denominado "desarrollo paralelo" (Edwards 1992; Pinney 1992) entre antropología y fotografía, causado, según esa autora, por una combinatoria de factores. Entre ellos marcaba la profesionalización de la antropología, su inserción en las universidades, y el desarrollo del trabajo de campo como práctica central; el cambio de intereses hacia el estudio detallado de la estructura y organización social -que no se consideraba visible fotográficamente-, junto a una crisis de confianza en la visión analógica de la fotografía, entre los más significativos.

Aunque para el caso de Lehamnn-Nitsche parezca evidente que el abandono de la fotografía como medio de conocimiento se produjo al mismo tiempo y posiblemente a causa del cambio en sus intereses académicos -dedicándose principalmente a los estudios folklóricos y sobre mitología y cosmología indígena dejando de lado la antropología física- podemos señalar que en gran parte esa creciente desconfianza en el medio fotográfico que se venía experimentando entre los académicos de aquellos años estaba también ligada a las fuertes críticas metodológicas que, en general y cada vez con mayor fuerza, venían recibiendo los estudios antropológicos.

De acuerdo a los aportes realizados por Benoit Massin (1996) sobre la antropología física alemana en su época imperialista, debemos destacar que para mediados de la década de 1890 la craniología, la "más científica" de los estudios antropométricos, estaba no sólo siendo puesta en cuestión sino que algunos antropólogos como el reconocido etnólogo americanista Paul Ehrenreich la había calificado como un verdadero "fiasco" (Ehrehreich 1897: 5-9). La capacidad de los estudios craniológicos para encontrar un tipo ideal esencial o estándar estaba siendo 
criticado tanto en lo que hace a su coherencia interna, como por ejemplo por los extensos estudios craniométricos realizados por el antropólogo húngaro Aurel von Törok (1842-1912), como en lo referente a la acción del medio sobre la capacidad craneana, que, como varios antropólogos reconocieron y comprobaron no permanecía inalterable sino que poseía plasticidad y por lo tanto podía variar incluso al interior de un mismo grupo étnico y debido a distintos factores externos (Massin 1996: 111).

Robert Lehmann-Nitsche no solamente estaba al tanto de estos debates, sino que, como vimos a lo largo de este trabajo varias veces había puesto en duda la utilidad de las mediciones corporales. Sin embargo, estas discusiones no eran entendidas como críticas al mismo concepto de "raza" que, como ya vimos, era entendida como una entidad positiva que existía efectivamente en la naturaleza, sino que se lo veía como un problema de corte metodológico. En efecto, aunque el enfoque métrico no había aportado evidencias conclusivas sobe el asunto, se esperaba que eso pudiera probarse a través de otro medio. Y la imagen fotográfica venía aquí a jugar un papel central, ya que no sólo la utilizó como otra de las herramientas con las que contaba para realizar sus estudios antropométricos sino que la consideraba incluso más útil que las mismas mediciones.

Para 1906, sin embargo, este antropólogo había abandonado toda pretensión de utilizar la fotografía en términos métricos o, como él lo llamaba en forma de "relevamientos matemáticos", del modo que lo había hecho en 1899 siguiendo las recomendaciones de la Escuela de Antropología de Paris, o tal como vimos más arriba, en la forma en que lo harían Chervin y la misión científica francesa en el altiplano boliviano en 1903. Luego de haber conocido el "método" Fritsch y trabajado la colección fotográfica de Boggiani, su intención era llegar a través de la fotografía a la visualización de los tipos raciales.

En este sentido, recordemos que había llegado a afirmar, siguiendo a Gustav Fritsch, que a través de la visualización de las fotografías dispuestas de determinada forma y sin necesidad de recurrir a las mediciones, podría captarse el tipo esencial de una "raza". Al visitar el Museo de de Historia Natural y Etnografía de Bremen, Lehmann-Nitsche había sido gratamente impresionado por que allí las 
colecciones estaban "guardadas en un lindísimo hall donde se pueden ver todas de un solo golpe de vista." ${ }^{53}$. Del mismo modo que para esos tiempos el arreglo de las vitrinas de los museos se realizaba con un determinado criterio (tipológico o geográfico, por ejemplo) que buscaba producir un efecto cognitivo, en este caso se esperaba que el sólo hecho de disponer las imágenes de determinada forma imágenes que por otra parte fueron producidas, a diferencia de las fotografías antropométricas, sin seguir reglas más o menos precisas- bastara para poder distinguir los rasgos esenciales de un grupo humano.

Por otra parte cabe tener en cuenta aquí el carácter fragmentario y poco sistemático que tuvieron las investigaciones en antropología física realizadas por LehmannNitsche con indígenas chaqueños. En primer lugar el trabajo de 1899 sobre los takshik fue realizado aprovechando la oportunidad que brindaba la presencia de ese grupo en Buenos Aires, en una investigación que no fue planeada ni premeditada. En ese sentido cabe señalar que, como vimos aquí, debido a que en ese momento las publicaciones del museo priorizaban los trabajos del área de geología y paleontología, más vinculados con los intereses de Moreno en relación a la cuestión de límites con Chile, la publicación de los resultados de esa investigación se postergó hasta 1904.

El viaje al ingenio La Esperanza se cumplió en circunstancias diferentes, como vimos, sus antecedentes pueden rastrearse hasta 1903, cuando Carlos Bruch estuvo de paso por allí y vislumbró la posibilidad de realizar un trabajo antropológico. Para el año 1906, cuando el museo, ya bajo la dirección de Samuel Lafone Quevedo, había pasado a depender de la Universidad Nacional de La Plata se dispuso de recursos económicos que permitieron la renovación de materiales, reformas edilicias, creación de nuevos laboratorios y el reinicio de la publicaciones científicas, esto significó además un renovado impulso para las ciencias antropológicas las cuales, por ejemplo, contaron al principio de este período con la mayor cantidad de cargos (García 2010: 146). Sin embargo Lahmann-Nistche, luego de este viaje, Lehmann-Nitsche no volvería al Chaco hasta la década de 1920,

\footnotetext{
53 "Informe sobre un viaje a Europa efectuado durante el segundo semestre del año 1900. Presentado al Señor Director del Museo de La Plata, por el Dr. Robert Lehmann-Nitsche, encargado de la sección antropológica". (AHPBA)
} 
momento en el que ya había abandonado por completo los estudios de antropología física. 


\section{CONSIDERACIONES FINALES}

El trabajo que aquí se ha expuesto se funda en el análisis de la producción, uso y circulación de fotografías sobre pueblos indígenas en relación al Museo de La Plata a finales del siglo XIX y principios del siglo XX. La labor sobre estas fotografias comenzó en 2005 motivado por el conocimiento que la misma podía aportar sobre la historia de los pueblos indígenas del Gran Chaco, objeto de análisis del Laboratorio de Investigaciones en Antropología Social donde me desempeñaba en ese momento como pasante. Al comenzar a indagar sobre ese archivo y su formación surgieron nuevos interrogantes que me condujeron a profundizar en el conocimiento sobre el contexto histórico en el cual se habían producido esas fotografías. Fue entonces que, deteniéndome en la historia del museo y de la ciencia en una etapa particular y vinculándome al mismo tiempo a su Archivo Histórico y Fotográfico, me introduje en la historia de la antropología y en particular en la historia de la relación entre esa disciplina y la fotografía a fines del siglo XIX.

El capítulo I se dedica a Carlos Bruch, cuya tarea como fotógrafo en distintos viajes y expediciones realizados por cuenta del museo entre 1887 y 1910 y especialmente los trabajos fotográficos que realizó junto a Robert LehmannNitsche entre los pueblos indígenas del gran Chaco produjeron los materiales visuales tratados a lo largo de este trabajo. En ese sentido se destacó la tarea de Bruch como fotógrafo-viajero y a través del análisis de algunas de las imágenes fotográficas que produjo se profundizó en el conocimiento de su particular concepción y conocimiento del procedimiento fotográfico.

En el Capitulo II se trabajó en referencia al límite entre las llamadas fotografía "científica" y fotografía "comercial", destacando que la distinción entre ambas no era una distinción entre géneros o modos de fotografiar diferenciados sino que respondía a cuestiones relativas al uso que se le daba a la imagen y en ese sentido a los canales por los cuales circulaba, como fue demostrado a través del análisis de la amplia circulación que tuvieron las fotografías del indígena guayaquí capturado en 1894. Al mismo tiempo esta cuestión se 
vinculó al límite establecido entre lo "profesional" y lo "amateur" en el campo de la antropología de fines del siglo XIX, demostrándose que esta era una frontera ambigua y difusa, como pudimos ver en el caso particular de Charles de La Hitte. Vimos además que durante el período estudiado la fotografía podía ser caracterizada como portadora de un doble valor ya que si por un lado podía funcionar como objeto de consumo, tal como mostramos refiriéndonos a la circulación de tarjetas postales, por otra parte también era utilizada en tanto objeto de conocimiento, y como tal circulaba por las redes científicas de intercambio de fines del siglo XIX y principios del siglo XX. En este último punto sirvió como caso de análisis la referencia a la colección fotográfica de Guido Boggiani editada por Robert Lehmann-Nitsche. Esto nos llevó a entender que la delimitación de lo "antropológico" o "etnográfico", al menos en lo tocante a la fotografía, era una definición en parte fluida y azarosa. Finalmente, pudimos ver como los debates que se daban al interior de la comunidad antropológica con respecto a los alcances y limitaciones de la fotografía aplicada a la actividad antropológica nos invitaban a componer una idea matizada de cual era la concepción del procedimiento fotográfico entre los antropólogos de fines del siglo XIX e inicios del siglo XX.

En el capitulo III brindamos un breve perfil de la formación profesional y llegada al Museo de La Plata de Robert Lehmann-Nitsche, quien se desempeñó como jefe de la sección de antropología de esa institución entre 1897 y 1930. Posteriormente nos referimos a las actividades que allí desarrolló, especialmente en lo relacionado a los estudios de antropología física, deteniéndonos en las concepciones que este autor manejaba sobre "raza" y "tipo racial". Posteriormente, y a fin de avanzar en el conocimiento sobre los límites que Lehmann-Nitsche reconocía en la utilización del procedimiento fotográfico, se analizó la discusión que Lehmann-Nitsche entabló con el abogado Ricardo Del Campo, que tuvo como objeto el caso de Amadeo Bezzi, y donde aquel antropólogo dejaba en claro su postura en cuanto a los límites de la fotografía, sobre la cual no tenía una concepción ingenua y que consideraba limitada en su capacidad para brindar conocimiento en otros campos de la ciencia como la medicina. La última parte del capítulo estuvo 
dedicada a tratar en detalle el trabajo de antropología el trabajo fotográficoantropométrico realizado en 1899 por sobre un grupo de indígenas takshik del Chaco argentino, mostrando cuales eran los antecedentes en materia de fotografía antropológica que Lehmann-Nitsche utilizó en esa ocasión, su pretendida conciliación entre las academias francesa y alemana. En ese sentido se describieron los procedimientos para la obtención de fotografías antropológicas formulados por la Escuela de Antropología de Paris, la definición de fotografías antropológicas y fotografías fisiognómicas enunciadas por el antropólogo Gustav Fritsch y las particularidades de su "método". Finalmente se subraya como ese modo de visualización de los tipos raciales, basado en el entrenamiento y la experiencia del observador, lejos de ser una práctica no científica, puede asimilarse a los hábitos de percepción que permiten discernir y estabilizar objetos para una comunidad científica y sin los cuales no habría ciencia.

En el Capitulo IV describimos y analizamos los antecedentes que propiciaron el viaje que en nombre del Museo de La Plata emprendieron hacia el ingenio La Esperanza, Carlos Bruch y Robert Lehmann-Nitsche. Luego nos referimos al trabajo indígena en los ingenios saltojujeños, su inserción en ese mercado laboral y las condiciones laborales observadas a inicios del siglo XX. Describiendo el contexto en que Bruch y Lehmann-Nitsche tomaron las fotografías y realizaron las mediciones corporales nos referimos a las relaciones entre fotografía, poder y resistencia, discutiendo algunas concepciones actuales acerca del papel de la fotografía y especialmente la imagen fotográfica en ese marco del análisis de las relaciones de poder. Posteriormente nos dedicamos a brindar los pormenores acerca de la divulgación de los resultados de esta campaña señalando el papel de los medios de prensa en la divulgación de los resultados de las expediciones científicas. Finalmente y ya dedicados al análisis de las fotografías que se produjeron en esa excursión marcamos el giro tomado por Lehmann-Nitsche en su concepción de la fotografía, su alejamiento de los "relevamientos métricos" y la influencias que sobre los trabajos fotográficos realizados en La Esperanza tuvo la obra fotográfica de Guido Boggiani. En ese sentido se marca una 
tendencia por parte del antropólogo alemán a lo que él llamaba "fotografía artística". Como cierre de ese capítulo postulamos que el abandono que hizo Lehmann-Nitsche de los trabajos de antropología física, trajo como consecuencia los cambios en su concepción de la fotografía en tanto forma de conocimiento.

Nos parece interesante destacar que a través del estudio de la fotografía, sus circunstancias de producción, circulación y uso en relación al Museo de La Plata pudimos identificar la existencia, el funcionamiento y los vínculos establecidos entre las redes de comercialización y de intercambio científico por las cuales las fotografías circularon y que nos marcaron que los límites entre lo científico y lo comercial o entre lo comercial y lo amateur no estaba tan claramente definidos como a veces se imagina. En este sentido también pudimos mostrar los vínculos existentes entre dos géneros fotográficos que en principio podrían parecer tan lejanos como la "fotografía antropológica" y la "fotografía artística".

Por otra parte, y retomando los planteos de la introducción, pudimos mostrar que las discusiones en torno a la utilización del procedimiento fotográfico en el contexto de la antropología de fines del siglo XIX y principios del siglo XX no nos permiten hablar de una "fotografía antropológica", como un concepto monolítico, en tanto práctica pautada por una serie de normas definidas que eran respetadas por una determinada comunidad científica, sino que más bien pudimos observar una variabilidad e incluso discordancia en torno a la concepción de la fotografía y sus alcances y límites para dar cuenta de la diversidad humana. Reparar en estas diferentes apreciaciones en referencia a las potencialidades del procedimiento fotográfico y conocer, como en el caso de Carlos Bruch, quien como vimos hizo referencia tanto a la presencia de de la cámara como a su propia presencia, evidenciando junto a lo representado, el mismo sistema de representación. Esto nos permitió poner en cuestión las afirmaciones que repetidamente atribuyen una concepción ingenua y naif a la sociedad del siglo XIX con respecto a la fotografía y su relación con la realidad. En ese sentido buscamos comprender qué lugar ocupaba la fotografía en la 
sociedad y no ya la representación de la sociedad en las imágenes fotográficas.

Finalmente, aquí aparece también la posibilidad de pensar en términos epistemológicos dado que se hacen evidentes discusiones respecto del dato y su interpretación y por lo tanto de lo que se entendía como ciencia. Discusiones y tensiones que son parte de la historia de la institución a la que pertenecemos y de las que somos herederos. La riqueza de las posibilidades interpretativas que surgen del análisis del período histórico que aquí presentamos puede ser tomada como referente para pensar las tensiones y las reflexiones actuales que atraviesan nuestra institución y que no se cierran ni agotan en un análisis que se funde sólo en lo estructural. Entendemos, junto con Fernand Braudel (1984), que debemos saber aprender a detenernos tanto en los aspectos coyunturales como en los acontecimientos que no son sino el resultado de múltiples atravesamientos y actores. Así, a través de las fotos, y los interrogantes que ellas nos plantearon, pudimos acceder a un momento histórico en cual los pueblos indígenas chaqueños estaban atravesando un profundo proceso de cambio -signado por la persecución y la muerte-, que implicaba, básicamente, el abandono de sus formas tradicionales de existencia, el despojo de sus territorios y su incorporación como mano de obra barata en los grandes emprendimientos económicos que avanzaban sobre el Chaco. Y a pesar de los recaudos que podamos tener en cuanto a la interpretación de la información contenida en las fotografías, ellas nos interpelaron desde el primer día y aún hoy lo siguen haciendo, planteándonos una exigencia que, tal como señala Agamben, no tiene nada de estético. En palabras de este autor: "Aun si la persona fotografiada estuviese hoy completamente olvidada, aun si su nombre hubiese sido borrado para siempre de la memoria de los hombres -y a pesar de esto; es más, precisamente por esto-, esa persona, ese rostro exigen su nombre, exigen no ser olvidados." (Agamben 2005:32) 


\section{BIBLIOGRAFÍA GENERAL}

AAVV 2002 Boggiani y el Chaco: una aventura del siglo XIX: fotografías de la colección Fric, Buenos Aires: Museo de Arte Hispanoamericano Isaac Fernández Blanco.

Acosta, L. 2006 "Una historia del período zoológico y la primera Sociedad Zoológica Argentina (1874-1881)", en Miscelánea N 105, Academia Nacional de Ciencias, Córdoba, pp. 1-23.

Agamben, G. 2005 Profanaciones, Adriana Hidalgo Editora, Buenos Aires.

Alexander, A. y M. A. Cuarterolo, 2003 "Fotografía y producción", en Producción y trabajo en la Argentina. Memoria fotográfica 1860-1960. Buenos Aires: Bice, Universidad de Quilmes.

Alvarado, M. 2000 "Indian Fashion. La imagen dislocada del indio chileno" en Revista de Estudios Atacameños № 20, pp. 137 - 151.

Alvarado, M., C. Odone, F. Maturana y D. Fiore (eds.) 2007 Fueguinos. Fotografías siglos XIX y XX. Imágenes e imaginarios del fin del mundo, Pehuén Editores, Santiago de Chile.

Alvarado M. y P. Mason 2005 "Fuegia fashion. Fotografía, indumentaria y etnicidad" en Revista Chilena de Antropología Visual No 6, pp. 2-18.

Alvarado, M. y otros 2001 Mapuche. Fotografías siglos XIX y XX. Construcción y montaje de un imaginario, Pehuén Editores, Santiago de Chile.

Ambrosetti, J. B. 1894 "Segundo viaje a Misiones por el Alto Paraná é Iguazú" en Boletín del Instituto Geográfico Argentino, Tomo XV, Buenos Aires.

Arenas, P. 2002-2003 "Naturaleza, arte y americanismo: Félix Ernst Adolf Methfessel (1836-1909)", en Société suisse des Américanistes / Schweizerische Amerikanisten-Gesellschaft Bulletin 66-67, pp. 191-198.

Arroyo, C. 2005 "Carlos Casado del Alisal", en Publicaciones de la Institución Tello Téllez de Meneses, № 76, Palencia, España, pp. 331-354.

Báez, C. 2001 "La prisión de las palabras. Fotografía mapuche del siglo XIX y textos que la han acompañado", en Revista Chilena de Antropología Visual, Universidad Academia de Humanismo Cristiano, $\mathrm{N}^{\circ} 1$

--------- 2004 “Detrás de la imagen. Los selk'nam exhibidos en Europa en 1889", en Revista Chilena de Antropología Visual, Universidad Academia de Humanismo Cristiano, $\mathrm{N}^{\circ} 4$. 
2005 "Uso y abuso. La construcción del indígena fueguino en los textos escolares a través de la imagen fotográfica", en Revista Chilena de Antropología Visual, Universidad Academia de Humanismo Cristiano, $\mathrm{N}^{\circ} 6$.

Báez, C. y P. Mason 2006 Zoológicos humanos. Fotografías de fueguinos y mapuche en el Jardin d'Acclimatation en Paris, siglo XIX, Pehuén Editores, Santiago de Chile.

Barabas, A., 2000. Utopías indias. Movimientos socioreligiosos en México, Quito, Ed. ABYA-YALA.

Barth, F., 1976. Los grupos étnicos y sus fronteras, México, FCE.

Bartolomé, M. 1997. Gente de costumbre y gente de razón. México, Siglo XXI.

-2000 El encuentro de la gente y los insensatos. La sedentarizaicón de los cazadores ayoreo en el Paraguay. Instituto Indigenista Interamericano-CEADUC, México.

Bauret 1999 De la fotografía, Editorial La Marca, Buenos Aires.

Beceyro, R. 2005 Ensayos sobre fotografía, Editorial Paidós, Buenos Aires.

Becker, H., 1996. "Explorando a sociedade fotograficamente" e "Balinese Character: uma análise fotográfica", en: Cadernos de Antropologia e Imagem, n² 2, NAI/UERJ, Rio de Janeiro, pp. 95-98.

Belting, H. 2007 Antropología de la imagen, Katz Editores, Buenos Aires-Madrid.

Benjamin, W. 2005 Sobre la fotografía, Pre-Textos, Valencia, España.

Bertoni, M. 1920. "La lengua guaraní como documento histórico. Apercu Ethnographique preliminaire du Paraguay oriental \& Haut Paraná », en Anales científicos paraguayos, Serie II, N 6, Puerto Bertoni,Alto Paraná, Paraguay, Imprenta y edición "Ex Sylvis".

Bialet Massé, Juan 1985 [1904] Informe sobre El estado de las clases obreras argentinas a comienzos del siglo, Tomos I y II (selección), Buenos Aires, CEAL.

Birabén, M. 1943a "Carlos Bruch" en Revista del Museo de La Plata, 1943, pp. 107132.

1943b en Revista de la Sociedad Entomológica Argentina 12, pp. 48-50.

Bilbao, S. 2004 Rememorando a Roberto Lehmann-Nitsche. Editorial La Colmena, Buenos Aires.

Boggiani, G. 1930 "Viajes de un artista por la América Meridional. Los Caduveos. Expedición al río Nabileque, en la región de las grandes cacerías de venados, Mato Grosso (Brasil)", en Revista del Instituto de Etnología de la Universidad Nacional de Tucumán, Vol. I, entrega 2, pp. 495-556. 
Bonati, I. 2006 Guido Boggiani. Orme Nell'ignoto, Turin: II Tucano Edizioni.

Bove, G. 1885 Note di un viaggio nelle Missioni ed Alto Parana. Génova.

Bourdieu, P. 1986 "L'illusion biographique", Actes de la Recherche en Sciences Sociales, No 62-63, pp. 69-72. (URL: http://persee.fr/showarticle.do?urn=arss 0335$\underline{5322} 1986$ num $62 \quad 1$ 2317).

-2003 [1965] Un arte medio. Ensayo sobre los usos sociales de la fotografía, Gustavo Gili, Barcelona.

Bourgade La Dardye, E. de 1889 Le Paraguay, Librairie Plon, Paris.

Bourgoing, A. de 1894 Viajes en el Paraguay y Misiones. Recuerdos de una expedición a los yerbales de Concepción, Cerro-Corá y Sierras de Amambay, etc., Tipografía, Litografía y Encuadernación "La Velocidad", Paraná.

Braudel, F. 1984 La historia y las ciencias sociales, Alianza Editorial, Madrid.

Brinton, D. G. 1891. The american race, New York.

1898. "The linguistic cartography of the Chaco region", en Proceedings of the American Philosophical Society, Tomo XXXVII, pp. 178-205.

Broeckmann, A. 2008 "Gustav Fritsch: Facialising the anthropological matrix", en Dietrich K. y A. Bank (ed.) An eloquent picture gallery. The south African portrait of Gustav Theodor Fritsch, 1863-1865. Jacana Media, Sudáfrica, pp. 144-152.

Bronner, S. J. 1989 "Object Lessons. The work of ethnological museums and collections » en Simon J. Bronner (ed.) Comsuming visions. Accumulation and display of goods in America, 1880-1920. New York/London, W. W. Norton \& Co.

Bruch, C. 1902 "La piedra pintada del arroyo Vaca Mala y las esculturas de la cueva de Junín de los Andes", en Revista del Museo de La Plata, Tomo X, pp. 173-176.

1904a "Descripción de algunos sepulcros calchaquíes, resultado de las excavaciones efectuadas en Hualfín (prov. de Catamarca)", en Revista del Museo de La Plata, Tomo XI, pp. 11-28.

1904b "La piedra pintada de Manzanito (territorio de Río Negro)", en Revista del Museo de La Plata, Tomo XI, pp. 71-72.

1911 "Exploraciones arqueológicas en las provincias de Tucumán y Catamarca", Revista del Museo de La Plata, Tomo XIX.

1911-1912 "Apuntes sobre antropometría de cuatro naturales del noroeste argentino" en Revista del Museo de La Plata, Tomo XVIII, pp. 47-52. 
Bruch, C. y F. Outes 1910 "Los aborígenes de la República Argentina", Ed. Angel Estrada y Cía., Buenos Aires.

1910 "Las viejas razas argentinas (6 cuadros murales y texto explicativo)", Buenos Aires.

Bruckner, S. 2003 "Spectacles of (Human) Nature: Commercial Ethnography between Leisure, Learning, and Schaulust". En H. G. Penny y M. Bunzl (eds.): Worldly provincialism. German Anthropology in the Age of Empire. The University of Michigan Press. Ann Arbor.

Buonocore, D. 1944 Libreros, editores e impresores de Buenos Aires. Buenos Aires: El Ateneo.

Burckhardt, C. 1898 «Rapport préliminaire sur une expédition géologique dans le région andine située entre Las Lajas (Argentine) et Curacautin (Chili) », en Revista Museo de La Plata, Tomo IX, pp. 197-220.

Burke, P. 2001 Visto y no visto. El uso de la imagen como documento histórico, Editorial Crítica, Barcelona.

Campi, D. y M. Lagos 1994 "Auge azucarero y mercado de trabajo en el Noroeste argentino, 1850-1930" Andes. Antropología e historia $N^{\circ} 6$, CEPIHA, Universidad Nacional de Salta, Salta.

Capinera, J. (Ed.) 2008 Enciclopedya of Entomology, Vol. 3, Springer, Dordrecht, The Netherlands.

Cardoso de Oliveira, R. 1992. Etnicidad y Estructura Social, México, CIESAS.

Cohen, A. 1985. The symbolic construction of community. London and New York, Routledge.

Chamberlain, A. 1905 "La colección Boggiani de Tipos Indígenas de Sudamérica Central (Reseña)", en American Anthropologist, Vol. 7, º2, pp.325-326.

Chervin, A. 1908 Anthropologie Bolivienne. Tome Premiere. Ethnologie, Demographie, Photographie metrique, Paris : Imprimerie Nationale.

Chicote, G. y M. Dalmaroni 2008 El vendaval de lo nuevo Literatura y cultura en la Argentina moderna entre España y América Latina (18801930), Beatriz Viterbo Editora, Buenos Aires.

Clastres, P. 1967 "Ethnologie des Indiens Guayaki. La vie sociales de la tribu" en L’Homme, Vol. 7, Núm. 4, pp. 5-24.

Collomb, G. 1998. Imagens do outro, imagem de si, en: Cadernos de Antropologia e Imagem, Rio de Janeiro. Vol. $6 \mathrm{~N}^{\circ} 1$. 
Congreso Nacional 1898 Investigación parlamentaria sobre agricultura, ganadería, industrias derivadas y colonización - Anexo C. Santa Fe, Chaco y Formosa, Taller Tipográfico de la Penitenciaría Nacional, Buenos Aires.

Conti, V., A. Teruel y M. Lagos 1988 "Mano de obra indígena en los ingenios de Jujuy a principios de siglo", en Conflictos y procesos de la Historia Argentina Contemporánea, CEAL 17, Buenos Aires, pp. 1-32.

Corbey, R. 1993 "Ethnographic showcases, 1870-1930" en Cultural Anthropology, 8 (3), pp. 338-369.

Cordeu, E. y A. Siffredi 1971 De la algarroba al algodón: Movimientos milenaristas del Chaco argentino, Juárez Editor, Buenos Aires.

Coronil, F. 2004 "Seeing History", en The Hispanic American Historical Review, 84:1, pp 1-4, Duke University Press.

Cristian Maestres, B. 2004. “¿Crónica de un etnocidio? La problemática del etnocidio en Crónicas de los indios guayaquis de Pierre Clastres" en Athenea Digital, № 005, Universidad Autónoma de Barcelona, pp. 1-9.

Cúneo, C. 1971 Las cárceles, Centro Editor de América Latina, 19, Buenos Aires.

Cutolo, V. O. 1975. Nuevo Diccionario Biográfico Argentino. Tomo IV. Editorial ELCHE, Buenos Aires.

Daston, L. 2008 "On Scientific Observation", en FOCUS—Isis, Vol. 99, pp. 97-110.

Daston, L. y P. Galison 1992 "The image of objectivity", en Representations, № 40, Special issue: Seeing Science, pp. 81-128.

Del Campo, R. 1899, "La monstruosidad en la delincuencia, en Criminalogía moderna, Buenos Aires, Agosto de 1899, año II, N 10, pp. 292-293.

Dias, N. 1994a "Looking at objects: memory, knowledge in nineteenth-century ethnographic displays", en G. Robertson y otros (Eds.) Travellers' tales. Narratives of home and displacement. Routledge, London and New York, pp. 164-176.

-1994b "Photographier et mesurer: les portraits anthropologiques", en Romantisme, Vol. 24, Numéro 84, pp. 37 - 49.

1997 "Modes de voir et modes de présentation: anthropologie et musées au XIXe siècle", en Antropologia Portuguesa, Vol. 14, pp. 7-21.

Dobrizhoffer, M. 1783. Geschichte der Abiponer, Tomo I, Wien.

Domenech, Ernesto (2003) Crimen y Fotografía, La Azotea Editorial Fotográfica, Buenos Aires. 
Dubois, P. 1986. El acto fotográfico. De la representación a la recepción, Paidós, Buenos Aires.

Edwards, E. (ed.), 1992. Anthropology \& Photography 1860-1920. Yale University Press, New Haven and London in association with The Royal Anthropological Institute, London.

Oxford: Berg Publishers.

2001 Raw Histories. Photographs, Anthropology and Museums.

Edwards, E. y J. Hart 2004 Photographs, Objects, Histories. On the materiality of images. New York: Routledge.

Edeb Piragi, P. 2001 "Los Aché del Paraguay y las revelaciones de la 'Palabra de los Ancestros' : de la tradición oral a la resistencia cultural" en Suplemento Antropológico, Vol.XXXVI, N¹, junio 2001, Asunción, pp. 147-245.

Ehrenreich, P. 1897 Anthropologischen studien über die Ubewohner Braziliens. Brauhnschweig, Vieweg.

-1898 "Neue Mittelingen über die Guayaki (Steinzeitmenschen) in Paraguay", en Globus, Tomo LXXIII, pp. 73-78.

-1904 „Die Ethnographie Südamerikas im Beginn des XX Jahrhunderts unter besonderer Berücksichtigung der Naturvölker", en Archiv für Anthropologie, N. F., Tomo III, pp. 46.

1906 "A ethnographia da America do Sul ao começar o seculo XX", en Revista do Instituto Historico e Geographico de São Paulo, vol. XI, pp. 280-305.

Epifanio, H. 1994 "Vida y "milagros" de Samuel y Arturo Boote", en Memorias del III Congreso de Historia de la Fotografía en Argentina, Buenos Aires, pp. 73-78.

Escobar, A. M. 2000 Contacto social y lingüístico. El español en contacto con el quechua en el Perú. Lima: Fondo Editorial, Pontificia Universidad Católica del Perú.

Fabre, A. 2005 Diccionario etnolingüístico y guía bibliográfica de los pueblos Indígenas sudamericanos

Farro, M. 2009 La formación del Museo de La Plata. Coleccionistas, comerciantes, estudioso y naturalistas viajeros fines del siglo XIX, Prohistoria ediciones, Rosario.

Ferrari, R. 1993 "Los inicios de la fotografía científica y técnica en la Argentina (1868-1900)", en Memorias del II Congreso de Historia de la Fotografía en la Argentina, Vicente López, Buenos Aires.

Fiore, D. 2005 "Fotografía y pintura corporal en Tierra del Fuego: un encuentro de subjetividades", en Revista Chilena de Antropología Visual, 6, http://www.antropologiavisual.cl 
Fiore, D. y M. L. Varela 2007 "Excavando fotos: arqueología de la cultura material y las prácitcas sociales de los pueblos fueguinos", en M. Alvarado y otros Fueguinos. Fotografías siglos XIX y XX. Imágenes e imaginarios del fin del mundo, Pehuén Editores, Santiago de Chile.

2009 Memorias de papel. Una arqueología visual de las fotografías de pueblos originarios fueguinos, Editorial Dunken, Buenos Aires.

Foucault, Michel (2000) Vigilar y castigar, nacimiento de la prisión, Siglo XXI Editores, México.

Fourdrignier, E. 1898 "Unité photographique", en Revue mensuelle de l'École d'Anthropologie de Paris, T. VIII, pp. 108-110.

Fricova, I. 1997 "...E procuri che non mi dimentichino i comuni amici....", en Iberoamericana Pragensia, Praga, año XXXI, pp. 132-160.

Fritsch, G. 1875 „Praktische gesichtspunkte für die Verwendung zweier dem Reisenden wichtigen technischen Hülfsmittel: Das Mikrosskop und der photographische Apparat", en G. Neumayer Anleitung zu Wissenschaftlichen Beobachtungen auf resisen, Stuttgart

1893 Die Gestalt der Menschen, Paul Verlag, Stuttgart.

2006 [1870] "Revista de Etnología", en J. Naranjo (ed.) Fotografía, antropología y colonialismo (1845-2006), Gustavo Gili, Barcelona.

2006 [1874] "Album etnológico-antropológico en fotografías de C. Dammann", en J. Naranjo (ed.) Fotografía, antropología y colonialismo (1845-2006), Gustavo Gili, Barcelona.

Furlong Cardiff, G. 1964 Angel Gallardo, Ediciones Culturales Argentinas, Buenos Aires.

Fuscaldo, L. 1985 "El proceso de constitución del proletariado rural de origen indígena en el Chaco", en M. Lischetti 1998, Antropología (2. ${ }^{a}$ ed.) Buenos Aires: Eudeba, pp. 337-359.

Gancedo, O. A. 1968 Estudio sobre los Guayaqui, Tesis Doctoral inédita, Facultad de Ciencias Naturales y Museo, Universidad Nacional de La Plata.

García, M. A. y G. Chicote (eds.) 2008 Voces de Tinta. Estudio preliminar y antología comentada de Folklore Argentino (1905) de Robert Lehmann-Nitsche. La Plata: Editorial de la Universidad de La Plata.

García, S. 2005 "Discursos, espacios y prácticas en la enseñanza científica de la universidad platense", en Saber y Tiempo, 20, pp. 19-62. 
García, S. 2010 Enseñanza científica y cultura académica. La Universidad de La Plata y las Ciencias Naturales (1900-1930), Prohistoria ediciones, Rosario.

Garrido, M., T. Kelly y A. Martínez 2007 "Las colecciones fotográficas del Acervo Histórico de la Facultad de Ciencias Naturales y Museo de la Universidad Nacional de La Plata", en Entrepasados. Revista de Historia, pp. 164-173.

Gay, J. P. 1863. Historia da Republica Jesuitica do Paraguay desde o descubrimento do rio da Prata até nossos días, anno de 1861. Rio de Janeiro.

Hervás y Panduro, L. 1800 Catálogo de las lenguas de las naciones conocidas, Tomo I, Madrid.

Giglioli, E. 1904 “Portrait of a Guayaqui Indian”, en Man, Vol. 4, p. 161.

Giordano, M. 2003 "Convenciones iconográficas en la construcción de la alteridad. Fotografías del indígena del Gran Chaco", en Discutir el canon. Tradiciones y valores en crisis, II Congreso Internacional de teoría e Historia de las Artes, $X$ Jornadas CAIA, Buenos Aires.

2004 "De Boggiani a Metraux", en Revista Chilena de Antropología Visual, 4. http://www.antropologiavisual.cl

2005. Discurso e imagen sobre el indígena chaqueño. Ediciones Al Margen. La Plata.

2009 "Estética y ética de la imagen del otro. Miradas compartidas sobre fotografías de indígenas del Chaco", en Aisthesis $N^{\circ} 46$, pp. 65-82.

2010 "Las comunidades indígenas del Chaco frente a los acervos fotográficos de "sus" antepasados. Experiencias de (re)encuentro", en Jeli, E.; L. da Silva Catela y M. Giordano (eds.) 2010 Fotografía e identidad. Captura por la cámara devolución por la memoria, Nueva Trilce Editorial, pp. 21-58.

Giraudo, S. y P. Arenas 2004 "Científicos europeos en el altiplano boliviano argentino: antropología, expediciones y fotos", en Anales de Museo de América 12, pp. 125-146.

Gómez, J. 1986. La fotografía en la Argentina. Su historia y evolución en el siglo XIX (1840-1899) Abadía Editora, Temperley, Buenos Aires.

Gordillo, G. 1995 "Después de los ingenios: La mecanización de la zafra saltojujeña y sus efectos sobre los indígenas del Chaco Centro-Occidnetal", en Desarrollo Económico 35 (137), pp. 105-126.

-2004 Landscapes of devils. Tensions of place and memory in the Argentinean Chaco, Duke University Press: Durham \& London. 
-2006 En el Gran Chaco: antropologías e historias, Buenos Aires: Prometeo Libros.

Haller, J. 1970 "Concepts of Race Inferiority in Nineteenth-Century Anthropology", en Journal of the History of Medicine, Vol. XXV (1), pp. 40-51.

Hannavy, J. (ed.) 2008 Encyclopedia of nineteenth-century photography, Vol. I., Routledge, New York \& Londres.

Herman, L. y A. Smetana 2001 "Catalog of the Staphylinidae (Insecta, Coleoptera): 1758 to the end of the second millennium", Vol. 1, Introduction, history, en Bulletin of the American Museum of Natural History, $\mathrm{N}^{\circ} 265$.

Hoek H. y Steinmann, G. 1906 „Erläuterung zur Routerkarten der expedition Steinmann, Hoek, v. Bistram in den Anden von Bolivia 1903-04", en Petermanns Geographische Mitteilungen, Vol. 52, Heft I, pp. 1-13.

Hoffman, K. y G. Wolff 2008 „Ethnologie Argentiniens und internationale Wissenszirkulation. Nachlass von Robert Lehmann-Nitsche (1872-1938)“, en Jahrbuch Preussicher Kulturbesitz, Band XLIV, Gebr. Mann Verlag, Berlin.

Holdich, T. H. 1904 In the countries of the king's award, London: Hurst \& Blackett, Ltd.

Holmberg. E. A. 1904 Investigación agrícola en la provincia de Jujuy, en Anales del Ministerio de Agricultura, Tomo I, N 6, Compañía Sudamericana de Billetes de Banco, Buenos Aires, pp. 1-167.

Ibañez Caselli, M. A., 2003a La educación intercultural bilingüe en argentina: un desafío, en: Qinasay, Revista de Educación Intercultural Bilingüe, Cochabamba, Bolivia, Año 1, $\mathrm{N}^{\circ} 1$.

2003b Interculturalidad en la Argentina: un concepto de moda aún no debatido, Segundo Taller Internacional de Interculturalidad, Santiago de Chile, 10-12 de diciembre de 2003.

Ibáñez Caselli, M. A. y L. Tamagno 1999. Dinámica de la lengua. Diversidad/Homogeneidad. Diferencia/Desigualdad, en: Ana Herzfeld y Yolanda Lastra (comp.). Causas sociales de la desaparición y del mantenimiento de las lenguas en América Latina, México, Univ. Sonora.

Iñigo Carrera, N. 1984 Campañas militares y clase obrera: Chaco, 1870-1930, Centro Editor de América Latina, Buenos Aires.

Jehel, P. J. 1998. "Fotografia e antropologia na França no século XIX" en Cadernos de Antropologia e Imagem 6 (1), Rio de Janeiro, pp. 123-137.

Jörg, M. 1943 "Carlos Bruch, un artista de la ciencia" en Revista de la Sociedad Entomológica Argentina, Vol. XII, N² 2, pp. 85-91. 
Karasik, G. 1988 El control e la mano de obra en un ingenio azucarero. El caso Ledesma (provincia de Jujuy), ECIRA, Jujuy.

Kerr, J. G. 1950 A naturalist in the Gran Chaco, Cambridge University Press, Londres.

Koch-Grünberg, T. 1906 "Indianertypen aus dem Amazonasgebiet nach eigenen Aufnahmen während seiner Reise in Brasilien", Verlegt bei Ernst Wasmuth A.-G., Berlin.

Kossoy, B. 2001 Fotografía e historia, La Marca Editorial, Buenos Aires.

Krauss, R. 1996 "Los espacios discursivos de la fotografía" en R. Krauss (ed.) La originalidad de la vanguardia y otros mitos modernos, Alianza Editorial, Madrid, pp. 145-163.

La Hitte, C. y H. ten Kate 1897. "Notes ethnographiques sur les indiens guayaquis et description de leurs caractères physiques" en Anales del Museo de La Plata. Antrhopologie II. Talleres de Publicaciones del Museo, La Plata, pp. 5-38.

Lafone Quevedo, S. 1899 Vocabulario toba-castellano-inglés, fundado en el Vocabulario y Arte del padre A. Bárcena, con equivalencias del indio López, en 1888, Revista del Museo de La Plata, T. IX, pp. 253-332.

Lagos, M.1992 "Conformación del mercado laboral en la etapa de despegue de los ingenios azucareros jujeños (1880-1920)", en Estudios sobre la historia de la industria azucarera argentina, Vol. II, Universidad Nacional de Jujuy-Universidad Nacional de Tucumán, Jujuy.

Lahille, F. 1898 "Guayaquis y Anamitas", en Revista del Museo de La Plata, Tomo VIII, pp. 453-459.

Latzina, F. 1889 "Estadísticas complementarias del censo" en Buenos Aires, Comisión Directiva del Censo, Censo general de población, edificación, comercio e industrias de la ciudad de Buenos Aires, levantado en los días 17 de agosto, 15 y 30 septiembre de 1887, Tomo II, Cía. Sudamericana de Billetes de Banco, Buenos Aires.

Laverni, P. 1901 El cultivo de la caña y la elaboración del azúcar en las provincias de Tucumán, Salta y Jujuy, Ministerio de Agricultura de la República Argentina, Buenos Aires.

Lehman-Nitsche, R. 1899a "Quelques observations nouvelles sur les indiens Guayaquis du Paraguay" en Revista del Museo de La Plata, Tomo IX, pp. 399-408.

1899b "Weitere Miteilungen über die guayakis in Paraguay", en Globus, Tomo LXXVI, pp. 78-80. 
1899c „¿Lepra precolombina? Un estudio crítico”, en Revista del Museo de La Plata, T. IX, pp. 337-370.

1899d „Antropología y Craneología“, en Revista del Museo de La Plata, Tomo IX, pp. 123-140.

1903 „Nähere Nachrichten über die Ermordung des derdenten italianischen reisenden Guido Boggiani“, en Globus, № 5, p. 82.

1904a "Etudes anthropologiques sur le Indiens Takshik (Groupe Guaicuru) du Chaco argentin", en Revista del Museo de La Plata, Tomo XI, La Plata.

1904b "Un caso raro de hendidura media congénita de la parte facial superior", en Revista del Museo de La Plata, Tomo XI, La Plata.

1904c La colección Boggiani de tipos indígenas de Sudamérica Central, Roberto Rosauer, Buenos Aires.

1904d "Sammlung Boggiani von Indianertypen aus dem zentralen Südamerika", en Zeitschrift für Ethnologie, Vol. 36, pp. 882-885.

1904e „Tipos de cráneos y cráneos de razas”, en Revista del Museo de La Plata, Tomo XI, La Plata, pp. 161-170.

1907a "Estudios antropométricos sobre los Chiriguanos, Chorotes, Matacos y Tobas (Chaco occidental)", Anales del Museo de La Plata, segunda serie, entrega I: 53-151. Buenos Aires: Coni hermanos, pp. 53-149.

1907b "L'atlas du tertiaire de Monte Hermoso, République Argentine", en Revista del Museo de La Plata, Tomo XIV.

1907c «Nouvelles recherches sur la formation pampéene et l'homme fossile de la République Argentine», en Revista del Museo de La Plata, Tomo 14, pp. 143- 488.

-1908 "Relevamiento antropológico de una india Guayaquí" en Revista del Museo de la Plata, Tomo XV, La Plata, pp. 91-101.

1916 "Etudes anthropologiques sur les indiens ona (Groupe Tshon), de la Terre de Feu. ", en Revista del Museo de La Plata, Tomo XXIII, pp. 174-184.

1919 "Peritaje somático en casos de filiación natural", en Revista de Criminología, Psiquiatría y Medicina-legal, pp. 80-93.

1977 [1916] »Boggiani artista-fotógrafo», en V. Diaz-Perez Coronario de Guido Boggiani, Asunción, pp. 75-80

Leigheb, M. 1986 Guido Boggiani: Pinttore, esploratore, etnógrafo, Novara, Torino. 
Lewerentz, A. 2008 "The racial theories and nude photography of Gustav Fritsch, 1870-1910", en Dietrich K. y A. Bank (ed.) An eloquent picture gallery. The south African portrait of Gustav Theodor Fritsch, 1863-1865. Jacana Media, Sudáfrica, pp. 152-161.

Lindman, C. A. G. 1899 „Några bilder från den Sydamerikanska vildmarken. El Gran Chaco", en Ymer: Tidskrift Utgifven af Svenska Sallskapet for Antropologi och Geografi, Estocolmo, pp. 45-80.

Lista, R. 1883 El territorio de las Misiones, Buenos Aires, imprenta La Universidad. fg I, Buenos Aires, pp. 434.

Lizer y Trelles, C. 1924 Anales de la Sociedad Científica Argentina

1937 Revista de la Sociedad Entomológica Argentina 9, pp. 18-21.

-1943a "Dr. Carlos Bruch" en Revista de la Sociedad Entomológica Argentina, Vol. XII, N², pp. 71-85.

-1943b en Anales de la Sociedad Científica Argentina 137, pp. 169-183.

1947 Curso de Entomología I. Introducción e historia de la Entomología I, 1. Museo Argentino de Ciencia Naturales "Bernardino Rivadavia", Buenos Aires, pp. 41-42.

Lopes, M. M. e I. Podgorny 2000 "The shaping of Latin American Museums of Natural History, 1850-1890", en Osiris, Vo. 15, 2000, pp. 108-118.

Mangels, H. 1895 “Beitrag zur die Guayaquís”, en Paraguay-Rundschau, Asunción.

Maresca, S. 1995. "Refletir as Ciências Sociais no espelho da fotografia", en Pluralismo, espaço social e pesquisa, Ed. Hucitec, San Pablo, pp.326-340.

Martínez, A. 2007 "Sobre algunas dificultades en la utilización de la fotografía como documento histórico-antropológico. El caso el archivo fotográfico del Museo de La Plata", en Taller Interdisciplinario "las poblaciones indígenas de la actual Argentina: pasado y presente", Resistencia, Inédito.

-2009 "Imágenes del "tiempo de los antiguos". Fotografía y lugares de memoria". en L. Tamagno 2009 (comp.) Pueblos indígenas, presencias, reclamos y demandas. Interculturalidad y estado nación, Buenos Aires, Editorial Biblos. En prensa.

2010 "Evangelization, Visual Technologies, and Indigenous Responses: The South American Missionary Society in the Paraguayan Chaco", en International Bulletin of Missionary Research, Vol. $34 \mathrm{~N}^{\circ} 2$, pp. 83-86. 
Martínez A. y L. Tamagno 2006 "La naturalización de la violencia. Un análisis de fotografías antropométricas de principios del siglo XX", en Cuadernos de Antropología Social № 24, pp. 93-112.

Masotta, C. 2003 "Cuerpos dóciles y miradas encontradas. Miniaturización de los cuerpos e indicios de la resistencia en las postales de indios argentinas (19001940)", en Revista Chilena de Antropología Visual, 3. http://www.antropologiavisual.cl

-2005 Representación e iconografía de dos tipos nacionales. El caso de las postales etnográficas en Argentina 1900-1930, en Arte y Antropología en Argentina, Fundación espigas, pp. 65-114.

Masterman, J. F. 1870. Siete años de aventuras en el Paraguay, Buenos Aires, pp. 183-184.

Mayntzhusen, F. 1911 "Los indios matacos del sudeste del Paraguay. Su influencia sobre los guayakís", en Revista de la Universidad de Buenos Aires, Tomo XV, pp. 333-344.

Mello Leitão C. 1943 en Revista de Entomologia, 14, Rio de Janeiro, pp. 528-529.

Miller, E. 1979 Los Tobas argentinos: Armonía y disonancia en una sociedad, México: Siglo XXI.

Miller, E. y J. Braunstein 1999 "Etnohistorical Introduction" en E. Miller (ed.) Peoples of the Gran Chaco, Westport, Conn.: Greenwood.

Ministerio de Obras Públicas de la provincia de Buenos Aires 1896 Memoria del Museo de La Plata 1895-1896, Talleres de Publicaciones del Museo, La Plata.

Moreno, F. P. 1890 "Reseña general de las adquisiciones y trabajos hechos en 1889 en el Museo de La Plata". Revista del Museo de La Plata, Tomo I, pp. 58-70.

1896 Memoria del Museo de La Plata, 1895-1896. La Plata: Talleres de Publicaciones del Museo.

Museo de La Plata 1907 Memoria correspondiente al año 1906, Imprenta Coni, Buenos Aires.

Navarro y Lamarca, C. 1910 Compendio de la historia general de América, Angel Estrada y Comp., Buenos Aires, pp. 63.

Niklison, J. 1989 Investigación sobre los indios matacos trabajadores, Universidad Nacional de Jujuy, Jujuy.

Pacheco de Oliveira, J. 1999, A viagem da volta. Etrnicidade política e reelaboraçaõ cultural no nordeste indígena, Rio de Janeiro, Contracapa Livraría Limitada. 
2006. "Pluralizando tradiciones etnográficas: sobre un cierto malestar en la antropología" en João Pacheco de Oliveira (comp.) Hacia una antropología del indigenismo, Lima: Contra Capa. Centro Amazónico de Antropología y Aplicación Práctica. Río de Janeiro, pp. 201-218.

Pastore, Carlos 1972. La lucha por la tierra en el Paraguay. Editora Antequera, Montevideo.

Pegoraro, A. 2009 Las colecciones del Museo Etnográfico de la Universidad de Buenos Aires: un episodio en la historia del americanismo en la Argentina18901927, Tesis Doctoral inédita, Facultad de Filosofía y Letras, UBA.

Penhos, M. 1995a "La fotografía del siglo XIX y la construcción de una imagen pública de los indios", en IV Jornadas de Teoría e Historia de las Artes. El arte entre lo público y lo privado. Buenos Aires, Facultad de Filosofía y Letras, CAIA, pp. 109125.

-1995b "Retratos de indios y actos de representación", en Memoria del IV Congreso de Historia de la Fotografía en la Argentina, Buenos Aires, pp. 89-94.

2005 "Frente y perfil. Una indagación acerca de la fotografía en las prácticas antropológicas y criminológicas en Argentina a fines del siglo XIX y principios del XX", en Arte y Antropología en la Argentina, Fundación Espigas, pp. 15-65.

Penny, G. H. 2002 "The Politics of Anthropology in the Age of Empire: German Colonists, Brazilian Indians, and the Case of Alberto Vojtech Fric", en Comparative Studies in Society and History, Vol. $45, N^{\circ} 2$, pp. 249-280.

Pepe, F., M. Añón Suárez y P. Harrison 2008 Identificación y restitución. Colecciones de restos humanos del Museo de La Plata, Edición del autor, La Plata.

Pestalardo, A. 2006 "La condición jurídica de los indígenas en la Argentina a fines del s. XIX y comienzos del XX, vista a la luz de un caso jurisprudencial", en Revista de la Asociación de Magistrados y Funcionarios de la Justicia Nacional, № 41/42. http://www.uca.edu.ar/esp/sec-fderecho/subsleynatural/esp/docsareas/pdf/pestalardo-01.pdf

Peters, E. y B. Mergens 1977 "'Doing the rest": The uses of photographs in American Studies", en American Quarterly, pp.280-303.

Pinney, Christopher 1992. "The parallel histories of anthropology and photography" en Elizabeth Edwards Anthropology and photography 1860-1920, Yale University Press in association with Royal Anthropological Institute. New Haven, pp.74-91.

Podgorny, I. 1992 "Huesos y flechas para la Nación: el acervo histórico de la Facultad de Ciencias Naturales y Museo de La Plata", Entrepasados, 2, 3, pp. 157165. 
-1995 “De Razón a Facultad: Ideas acerca de las funciones del Museo de La Plata en el período 1890-1918", en Runa, Vol. 22, pp. 89-104.

-1999 Arqueología de la educación. Textos, indicios, monumentos, Sociedad Argentina de Antropología, Buenos Aires.

2001 "La clasificación de los restos arqueológicos en la argentina, 18801940. Primera parte: La diversidad cultural y el problema de la antigüedad del hombre en el Plata", en Saber y Tiempo 12, pp. 5-26.

2002 "Ser todo y no ser nada: paleontología y trabajo de campo en la Patagonia argentina a fines del siglo XIX", en S. Visacovsky y R. Guber (comp.) Historia y estilos de trabajo de campo en Argentina, Antropofagia, Buenos Aires, pp. 31-77.

2005 "La derrota del genio. Cráneos y cerebros en la filogenia argentina", en Saber y Tiempo, Vol. 5, N²0, pp. 63-106.

-2006 “La ciencia moderna y la imagen”, TodaVía, v.13, p. 7-13.

2009 El sendero del tiempo y las causas accidentales. Los espacios de la prehistoria en la Argentina, 1850-1910, Prohistoria: Rosario.

Podgorny, I. y M. M. Lopes 2008. El desierto en una vitrina. Museos e historia natural en la Argentina, 1810-1890. México, Limusa.

Podgorny, I. y T. Kelly 2010 "“Faces Drawn in the Sand": A Rescue Project of Native Peoples' Photographs Stored at the Museum of La Plata, Argentina", en MIR, Vol. 39, pp. 98-113.

Príamo, L. 1999 "Fotografía y vida privada (1870-1930)" en Historia de la vida privada en Argentina, Tomo II La Argentina plural, Editorial Taurus, Buenos Aires, pp. 276-299.

Priamo, L. y A. Alexander 1998 "H. G. Olds. Noticias de un desconocido", en AAVV. H. G. Olds: fotografías, 1900-1943, Buenos Aires: Fundación Antorchas, 1998.

Poole, D. 1999 "Raza y retrato: hacia una antropología de la fotografía", en Cuicuilco, Vol. $6 \mathrm{~N}^{\circ}$ 16, pp. 225-252, Mexico.

2000 Visión, raza y modernidad. Una economía visual del mundo andino en imágenes, SUR, Casa de Estudios del Socialismo, Lima.

Proctor, R. "From Anthropologie to Rassenkunde in the German anthropological tradition", en G. W. Stocking Bones, bodies, behavior: essays on biological anthropology, History of Anthropology, Vol. 5, The University of Wisconsin Press, pp. 138-179. 
República Argentina 1902 Memoria presentada al tribunal nombrado por el Gobierno de su majestad británica "para considerar e informar sobre las diferencias suscitadas respecto a la frontera entre las Repúblicas Argentina y Chilena a fin de justificar la demanda argentina de que el límite se trace en la cumbre de la Cordillera de Los Andes de acuerdo con los tratados de 1881 y 1893." Londres: William Clowes é hijos, Ltd.

Riccardi, A. 1986. "El personal del Museo de La Plata entre 1890 y 1896", en Novedades del Museo de La Plata 1 (10), La Plata, pp. 82.

Riccardi, A. 2008 "El Museo de La Plata en el avance del conocimiento geológico a fines del Siglo XIX", en Aceñolaza, F. (ed.) Los geólogos y la geología en la Historia Argentina, Serie Correlación Geológica 24, Instituto Superior de Correlación Geológica-San Miguel de Tucumán, pp. 109-125.

Ringuelet, R. 1967 "Historia, estado actual y futuro de la zoología en la República Argentina", en Acta Zoológica Lilloana XXIII, Tucumán, pp. 5-43.

Riquelme, Q. 2003. Los sin tierra en Paraguay. CLACSO, Buenos Aires.

Rodríguez, J. 2006 Civilizing Argentina: science, medicine and the modern state, Chapel Hill: The University of North Carolina Press.

Russo, E. 1998 Diccionario de cine, Buenos Aires, Paidós.

Rutledge, I. 1987 Cambio agrario e integración. El desarrollo del capitalismo en Jujuy: 1550-1960, ECIRA-CICSO, Tucumán.

Salvatore, R. 2001 "Sobre el surgimiento del estado médico legal en la Argentina [1890-1940]", en Estudios Sociales. Revista Universitaria Semestral, año XI, No 20, Santa Fe, Argentina, Universidad Nacional del Litoral, pp. 81-114.

Samain, E. 1998, No fundo dos olhos: os futuros visuais da antropolgia, en: Cadernos de Antropologia e Imagem, Rio de Janeiro. Vol. 6 № 1.

Santamaría, D. 1986 Azúcar y sociedad en el noroeste argentino, Ediciones del IDES, Buenos Aires.

-1994 "Las relaciones económicas entre tobas y españoles en el Chaco occidental, siglo XVIII", en Andes 6, pp. 273-300.

Schleh, E. 1910 La industria azucarera argentina. Pasado y presente, Buenos Aires

-1921 La industria azucarera en su primer centenario. 1821-1921. Consideraciones sobre su desarrollo y estado actual, Establecimiento Gráfico Ferrari Hnos., Buenos Aires

-1945 Noticias históricas sobre el azúcar en la Argentina, Centro Azucarero Argentino, Buenos Aires. 
1953 El azúcar en la Argentina. Reseña informativa de la industria azucarera en todos sus aspectos, Cesarini Hnos., Buenos Aires.

Schedl, K. 1946 en Zentralblatt für das Gesamtgebiet der Entomologie 1: 63.

Scherer, J. 1992, The photographic document: photographs as primary data in anthropological enquiry, en: Edwards E. (comp.) Anthropology and Photography. 1860-1920. New Haven: Yale University Press, pp. 32-41.

Scotti, P. 1985 I contribute americanistici di Guido Boggiani, Genova Liberia degli studi.

Sekula, A. 1986 "The body and the archive", en October, 39, pp. 3-65.

Shapin S. y S. Schaffer 1985. Leviathan and the Air-Pump. Hobbes, Boyle, and the Experimental Life, Princeton University Press.

Sierra e Iglesias, J. 1998 Un tiempo que se fue. Vida y obra de los hermanos Leach. Universidad Nacional de Jujuy, San Pedro de Jujuy.

Solomon-Godeau, A. 1991 Photography at The Dock: Essays on Photographic History, Institutions, and Practices (Media and Society), University of Minnesota Press.

Sontag, S. 2006 Sobre la fotografía, Alfaguara: Buenos Aires.

Spadafora A. M. 2006 "Entre la historia, el mito y el ritual: notas sobre el arte chamacoco (Alto Paraguay)", en Boletín de Antropología, Año/Vol. 20, N 37 Universidad de Antioquia Medellín, Colombia pp. 118-130.

Spencer, F. 1992 "Some notes on the attempt to apply photography to anthropometry during the Econ. Half of the nineteenth century", en: Elizabeth Edwards (ed.) Anthropology \& Photography 1860-1920. The Royal Anthropological Institute and Yale University Press, New Haven and London, pp. 99-107.

Stemmler, J. K. 1993 "The Physiognomical Portraits of Johann Caspar Lavater", en The Art Bulletin, Vol. 75, No. 1, pp. 151-168.

Street, B. 1990 "Reading Faces: Physiognomy Then and Now", en Anthropology Today, Vol. 6, No. 6, pp. 11-12.

Tagg, J. 1988 Photography At The Dock: Essays on Photographic History, Institutions, and Practices, University of Minnesota Press.

Tamagno, L. 2001 Nam Qom hueta'a na doqshi Ima'. Los tobas en la casa del hombre blanco, Identidad, memoria y utopía. La Plata, Ediciones Al Margen. 
2003 Identidades, saberes, memoria histórica y prácticas comunitarias. Indígenas tobas migrantes en la ciudad de La Plata, capital de la provincia de Buenos Aires, Argentina, en: Campos. Revista de Antropología Social. Universidade Federal do Paraná, Brasil.

-2009 Pueblos indígenas: interculturalidad, colonialidad y política, Editorial Biblos, Buenos Aires.

Tell, V. 2001 "La toma del desierto. Sobre la auto-referencialidad fotográfica" en El poder la Imagen, VIII Jornadas CAIA, Buenos Aires.

2003 "Instantáneas: la fotografía en algunas caricaturas de El Mosquito" en Discutir el canon. Tradiciones y valores en crisis, II Congreso Internacional de teoría e Historia de las Artes, $X$ Jornadas CAIA, Buenos Aires.

Tello, E. 1888 Descripción de la provincia de Jujuy. Informes, objetos y datos que presenta el Comisionado Provincial, Senador Nacional, D. Eujenio Tello a la Exposición Universal de 1889 en Paris, Imprenta de J. Petruzzelli, Jujuy.

ten Kate y La Hitte 1897 « Notes ethnographiques sur les Indiens Guayaquis », en Anales del Museo de La Plata, Antropología, II.

Teruel, A. 2005 Misiones, economía y sociedad. La frontera chaqueña del Noroeste argentino en el siglo XIX, Universidad Nacional de Quilmes, Buenos Aires.

Trinchero, E. 2000 Los dominios del demonio. Civilización y barbarie en las fronteras de la nación. El Chaco central, Eudeba, Buenos Aires.

Torre Revello, J. 1944-1945 "Contribución a la biobibliografía de Roberto LehmannNitsche", en Boletín del Instituto de Investigaciones Históricas XXIX, 101-104, pp. 724-805.

Torres, L. M. 1903 "Bruch, C. Descripción de algunos sepulcros calchaquíes (Reseña)", en Anales de la Sociedad Científica Argentina, Vol. 55, pp. 95-96.

Tucker, J. 2005 Nature exposed. Photography as an eyewitness in Victorian Science. John Hopkins University Press, Baltimore.

-2006 "The historian, the picture and the archive", en Isis 97, pp. 111-120.

Vellard J. 1934. "Les Indiens Guayakí", en Journal de la Société des Américanistes, T. 26-2, pp. 223-292.

Verneau, R. 1897 "Les Indiens Guayaquí du Paraguay", en L'Anthropologie VIII, pp. 374.

Viviani, A. 1951 Guido Boggiani : alla scoperta del Gran Chaco, Turin : Paravia.

Vogt, F. 1902 „Material zur Ethnographie und Sprache der Guayakí-Indianer“, en Zeitschrift für Ethnologie, Berlin, Tomo XXXIV, pp. 30-43. 
1903 „Material zur Ethnographie und Sprache der Guayakí-Indianer“, en Zeitschrift für Ethnologie, Berlin, Tomo XXXV, pp. 849-874.

-1904 die Indianer des Obern Paraná, en Mitteilungen der Anthropologischen Gesselschaft in Wien, Tomo XXXIV, pp. 200-221 y 353-376.

1911 Los Guayaquíes, en Revista de la Universidad de Buenos Aires, Tomo XV, pp. 192-201.

Von den Steinen, K. 1895 „Steinzeit-Indianer in Paraguay“, en Globus, Tomo LXVII, 1895, pp. 248-249.

1901 „Die Guayaquí-Sammlung des Hrn. Dr. V. Weickhmann“, en Verhandlugen der Berliner Gesselschaft für Anthropologie, Ethnologie und Urgeschichte, Tomo XXXIII, pp. 267 -271.

Von Ihering, H. 1895. "A civilisacao prehistorica do Brazil meridional", en Revista do Museu Paulista, Vol. I, Rio de Janeiro, pp. 111.

Von Rosen, E. 1904 The Chorote Indians in the Bolivian Chaco. A preliminary report. Ivar Haeggströms Bocktryckeri, Estocolmo.

Wehrli, L. 1898 „Rapport préliminaire sur mon expédition géologique dans la Cordillére Argentino-Chilienne, du $40^{\circ}$ et $41^{\circ}$ latitude sud (region du NahuelHuapi) », en Revista del Museo de La Plata, Tomo IC, pp. 221-242.

Wright, P. 2003 "Colonización del espacio, la palabra y el cuerpo en el Chaco argentino", en Horizontes Antropológicos, Porto Alegre, Año 9, № 19, pp. 137-152.

Zimmerman, A. 2001 "Looking Beyond History: The Optics of German Anthropology and the Critique of Humanism" in Studies in History and Philosophy of Biological \& Biomedical Sciences, Vol. 32, No. 3, pp. 385-411.

2003 "Adventures in the skin trade: German anthropology and colonial corporeality" en H. Glenn Penny and Matti Bunzl (Eds.) Wordly provincialism. German anthropology in the age of empire, The University of Michigan Press, Ann Arbor, pp. 156-178.

Zuleta, M. C. 1990 "Mercado de trabajo y reclutamiento de mano de obra en los ingenios azucareros de Salta y Jujuy 1880 1940." En: Estudios e Investigaciones № 2, Tomo 1, FHCE, La Plata. 


\section{FUENTES}

DAMLP: Departamento de Arqueología, Museo de La Plata.

AGN: Archivo General de la Nación, Archivo Fotográfico.

AHCA: Archivo Histórico de la Cancillería Argentina.

AHMSPB: Archivo Histórico y Museo Servicio Penitenciario Bonaerense.

AHPBA: Archivo Histórico de la Provincia de Buenos Aires.

AHFMLP: Archivo Histórico y Fotográfico Museo de La Plata.

AFME: Archivo Fotográfico Museo Etnográfico "Juan Bautista Ambrosetti", Facultad de Filosofía y Letras-UBA.

ADE-MACN: Archivo División Entomología, Museo Argentino de Ciencias Naturales "Bernardino Rivadavia".

ETHZ: Archivo de imágenes de la Biblioteca del Eidgenössische Technische Hoschschule, Zürich, Suiza.

Legado Robert Lehamnn-Nitsche, Instituto Iberoamericano, Berlin. 